\title{
MARIÂNGELA GRACIANO
}

\section{A educação nas prisões: um estudo sobre a participação da sociedade civil}

Tese de Doutorado apresentada à Banca Examinadora da Faculdade de Educação da Universidade de São Paulo, como exigência parcial para obtenção do título de DOUTORA em Sociologia da Educação.

Orientadora: Profa ${ }^{a}$ Doutora Flávia Inês Schilling

São Paulo

2010 


\title{
Autorizo a reprodução e divulgação total ou parcial deste trabalho, por qualquer meio convencional ou eletrônico, para fins de estudo e pesquisa, desde que citada a fonte.
}

\author{
Catalogação da Publicação \\ Serviço de Documentação \\ Faculdade de Educação da Universidade de São Paulo
}

Graciano, Mariângela

A educação nas prisões: um estudo sobre a participação da sociedade civil. Mariângela Graciano; orientadora Flávia Inês Schilling. - São Paulo, 2010.

$261 \mathrm{f}$.

Tese (Doutorado)--Universidade de São Paulo, 2010.

1. Educação em prisões. 2. Educação de adultos presos. 3. Educação não formal. 4. Educação não escolar. 5. Direitos humanos. 6. Direito à educação. I. Schilling, Flávia. II. Título. III. Título: A educação nas prisões: um estudo sobre a participação da sociedade civil.

Nome: Mariângela Graciano

Título: A educação nas prisões: um estudo sobre a participação da sociedade civil. 
Tese de Doutorado apresentada à Banca Examinadora da Faculdade de

Educação da Universidade de São

Paulo, como exigência parcial para obtenção do título de DOUTORA em Sociologia da Educação.

Aprovado em:

Banca Examinadora:

Prof ${ }^{a}$ Dra. Flávia Inês Schilling

Prof $^{\circ}$ Dr.Fernando Salla

Prof ${ }^{a}$ Dra. Maria Victoria Benevides

Prof ${ }^{\circ}$ Dr. Sérgio Haddad

Prof ${ }^{\circ}$ Dr. Sérgio Salomão Shecaira 
Tereza, João e Chico Minha mãe, Nice e Vicente, meu pai, com saudade 


\section{AGRADECIMENTOS}

Esta tese é resultado de um trabalho acadêmico, mas também, e sobretudo, da solidariedade, apoio e confiança demonstrados por muitas pessoas.

Por isso, agradeço, de maneira muito especial, à prof ${ }^{a}$ Dra. Flávia Inês Schilling não apenas por sua orientação dedicada, firme e acolhedora, características marcantes do seu jeito de educar, mas principalmente, por ter acreditado que o trabalho seria concluído, mesmo quando muitos percalços surgiram ao longo do caminho.

À prof ${ }^{a}$ Dra. Maria Victoria Benevides e ao $\operatorname{prof}^{o}$ Dr. Fernando Salla, pelas preciosas críticas e sugestões feitas no Exame de Qualificação.

A toda a equipe da Ação Educativa, sua diretoria e colegas queridas/os, que apoiaram este trabalho de muitas maneiras: da concessão de licença para a redação final, à escuta atenciosa e sensível. De maneira muitíssimo especial, agradeço a atenção de Marina Gonzalez, Fernanda Campagnucci, Aline Abbonízio, Hugo Fanton e Abrão Neto, colegas do programa Observatório da Educação.

Agradecimento especial a Pedro Pontual, pela leitura e comentários que muito contribuíram para este trabalho; a Sérgio Haddad, pelo apoio firme e permanente; e a Fernanda Fernandes, pelo companheirismo em todo o percurso.

Com extrema admiração pelo compromisso com a efetivação universal da dignidade humana, agradeço a todas as pessoas que compartilharam sua experiência, emoções, reflexões e informações por meio das entrevistas concedidas e conversas informais estabelecidas em diferentes momentos e lugares.

A Taisa Souza, pelo trabalho de transcrição das muitas horas de entrevistas, a Denise Gomide, pela revisão atenta do texto, e a Elisabete Oliveira pelo apoio contínuo.

Por fim, agradeço à minha família, pela paciência e compreensão com a minha ausência durante o período de elaboração deste trabalho: minha filha Tereza e meu filho João, por existirem e darem sentido ao mundo; ao Chico, meu companheiro, pelo apoio e escuta permanentes; às minhas irmãs, mãe e amigas: Anéris, Claudia, Nice, Maria Soledade e Maria Martins, mulheres queridas, por cuidarem de tudo em casa. 


\section{RESUMO}

GRACIANO, M. A educação nas prisões: um estudo sobre a participação da sociedade civil. 2010. 261 f. Tese (Doutorado) - Faculdade de Educação, Universidade de São Paulo, São Paulo, 2010.

Esta pesquisa propõe a investigação das práticas educativas desenvolvidas por organizações da sociedade civil e pessoas voluntárias no interior do sistema penitenciário do estado de São Paulo. Tais iniciativas, que se constituem em partilha da responsabilidade entre Estado e sociedade civil, são previstas e estimuladas em normas que versam sobre a educação no ambiente prisional. Diante da falta de informações sistemáticas acerca dessas parcerias, esta pesquisa teve entre seus objetivos: a caracterização dos tipos de parcerias estabelecidas; a identificação das motivações, intencionalidades e objetivos que regem tais iniciativas; a verificação de diferenças entre as atividades propostas nos presídios masculinos e femininos, entre outros. A pesquisa permitiu identificar sinais de mudança no campo da educação em prisões. Estes sinais, muitas vezes, parecem coerentes com as alterações percebidas por diversos autores, no Brasil e no mundo, no que diz respeito à ampliação do encarceramento, constituição de um sistema de privilégios no qual se baseia a manutenção da ordem interna às prisões, e abandono do ideal de reabilitação. No entanto, ações de governos, organizações da sociedade civil e também no campo da pesquisa indicam que a educação nas prisões vem se constituindo como um campo específico, tanto de análise quanto para a formulação de ações públicas, ainda incipientes, mas notáveis.

Palavras-chave: educação em prisões; educação de adultos presos; educação não formal; educação não escolar; direitos humanos; direito à educação. 


\begin{abstract}
GRACIANO, M. Prison education: a study about the participation of civil society. 2010.

261 f. Tese (Doutorado) - Faculdade de Educação, Universidade de São Paulo, São Paulo, 2010.

The purpose of this research is the investigation of educational practices carried out by civil society organizations and volunteer individuals in the São Paulo State prison system. These initiatives consist of sharing responsibility between the State and civil society, being comprehended and stimulated in guidelines concerning education in the prison environment. Considering the scarcity of systematic information concerning these partnerships, one of the goals of this research is the characterization of partnerships established; the identification of the motivations, intentionality and purposes that guide these initiatives; the differences between activities developed in male and female prisons, among others. The research made possible to identify evidences of changes in prison education. These evidences are often in accordance with the ones perceived by different authors in Brazil and in the world concerning the expansion of incarceration, the emergence of a privilege system upon which the maintenance of the prison internal order is founded, as well as the abdication of the rehabilitation purpose. However, both government's and civil society organizations' actions, as well as the research area, indicate that prison education has been developing to become a specific field for both analysis and public policymaking, still incipient but already distinguishable.
\end{abstract}

Key words: prison education; education of imprisoned adults; non-formal education; nonschool education; human rights; right to education 


\section{LISTA DE SIGLAS}

CEAA Campanha de Educação de Adolescentes e Adultos

Cedeca Centro de Defesa dos Direitos da Criança e Adolescente

CDI

Centro de Democratização da Informática

CNBB

Conferência Nacional dos Bispos do Brasil

Confintea

Conferência Internacional sobre Educação de Jovens e Adultos

ECA

Estatuto da Criança e do Adolescente

FAT

Fundo de Amparo ao Trabalhador

Febem

Fundação Estadual do Bem-Estar do Menor

Fiesp

Federação das Indústrias do Estado de São Paulo

Funap

Fundação Professor Doutor Manoel Pedro Pimentel (a partir de 1994)

Funap

Instituto de Amparo ao Trabalhador Preso (entre 1976 a 1994)

IBGE

Instituto Brasileiro de Geografia e Estatística

Inep

Instituto Nacional de Estudos e Pesquisas Educacionais Anísio Teixeira

LDB

Lei de Diretrizes e Bases da Educação Nacional

LEP

Lei de Execução Penal

MEC

Ministério da Educação

Mobral

Movimento Brasileiro de Alfabetização

OEA

Organização dos Estados Americanos

$\mathrm{ONU}$

Organização das Nações Unidas

PEDH-SP Programa Estadual de Direitos Humanos do Estado de São Paulo

PFC

Penitenciária Feminina da Capital

PDHCSP Plano de Direitos Humanos da cidade de São Paulo

PNE

Plano Nacional de Educação

Pidesc

Pacto Internacional sobre Direitos Econômicos, Sociais e Culturais

PNDH

Programa Nacional de Direitos Humanos

SAP

Secretaria de Administração Penitenciária do Governo do Estado de São Paulo

SEA

Serviço de Educação de Adultos

Senai

Serviço Nacional de Aprendizagem Industrial

Sesi

Serviço Social da Indústria

UNE

União Nacional dos Estudantes

Unesco

Organização das Nações Unidas para a Educação, a Ciência e a Cultura 


\section{SUMÁRIO}

INTRODUÇÃO - A EDUCAÇÃO NAS PRISÕES: UM ESTUDO SOBRE A PARTICIPAÇÃO DA SOCIEDADE CIVIL

13

A) Justificativa, objetivos e hipóteses

C) O campo pesquisado - Breve descrição, algumas constatações

D) Notas para orientar o percurso

CAPÍTULO 1 - A EDUCAÇÃO NA PRISÃO QUE SE TRANSFORMA

1.1 Breve retrato da prisão

1.1.1 Seleção étnico-racial

1.1.2 Ampliação do encarceramento

1.1.3 Fim do ideal de reabilitação

1.1.4 Assistências e trabalho na prisão brasileira

1.2 A educação nas prisões, segundo as normas

1.2.1 $O$ plano internacional

1.2.1.1 A educação de jovens e adultos

1.2.1.2 A educação nas prisões 51

1.2.2 $O$ âmbito nacional

1.2.2.1 Programa Nacional de Direitos Humanos

1.2.2.2 Programa Estadual de Direitos Humanos do Estado de São Paulo

1.30 que é educação nas prisões - possibilidades de análise 66

$\begin{array}{ll}\text { 1.3.1 A educação fora da escola } & 67\end{array}$

1.3.2 Inclusão $\quad 69$

1.3.3 Campos de atuação

1.3.4 Tensão entre o formal e o não formal 75

1.3.5 Educação X Segurança

1.3.6 Educação informal e os elementos da prisão pós-disciplinar 78

1.4 Algumas conclusões $\quad 81$

1.4.1 A prisão no Brasil

1.4.2 A educação nas prisões, segundo as normas

1.4.3 A educação nas prisões - algumas possibilidades de análise 83 
CAPÍTULO 2 - EDUCAÇÃO NÃO FORMAL NAS PRISÕES -

A CONSTRUÇÃO DE UM CENÁRIO 85

2.1 A ação do governo federal 86

2.1.1 O Ministério da Justiça 86

2.1.1.1 Estagiários no sistema prisional 88

2.1.1.2 Estagiários no sistema prisional paulista $\quad 89$

2.1.1.3 ProJovem prisional 90

2.1.1.4 Outros convênios

2.1.1.5 O Sistema " $S$ "

2.1.1.6 Cooperação técnica 97

2.1.2 O Ministério da Educação 99

2.1.2.1 Educando para a Liberdade 99

2.1.2.2 Brasil Alfabetizado 102

2.2 Ações de governo em São Paulo 103

2.3 A mídia e a educação de pessoas presas 105

2.3.1 Limites da análise 105

2.3.2 Deu no jornal 106

2.3.2.1 As práticas não formais 108

2.3.2.2 Os atores 111

2.3.2.3Exame de certificação 113

2.3.2.4 Inclusão Digital 114

$\begin{array}{ll}\text { 2.3.2.5 Profissionalização } & 117\end{array}$

2.3.2.6 Outras considerações $\quad 119$

2.3.2.7 Temas relacionados 120

2.3.2.8 Trabalho para a educação 120

2.3.2.9 Diagnóstico da precariedade $\quad 122$

2.4 Algumas conclusões $\quad 125$

2.4.1 A produção do silêncio 125

2.4.2 Diversidade e fragmentação 126

$\begin{array}{ll}\text { 2.4.3 Quem são os atores } & 127\end{array}$ 
CAPÍTULO 3 - LIMITES E POSSIBILIDADES DA ATUAÇÃO DA SOCIEDADE CIVIL NA EDUCAÇÃO EM DUAS PRISÕES DE SÃO PAULO

3.1 Quem faz e o que faz

3.1.1 Curso Promotoras Legais Populares 130

3.1.2 Projeto Quem Somos Nós 133

3.1.3 Projeto Leitura Livre/ Leitura Ativa 138

3.1.4 Grupo de Diálogo Universidade Cárcere e Comunidade (GDUCC) 142

3.1.5 Oficinas Prevenção DST/AIDS 147

3.1.6 Oficina de Capacitação em Rádio - Universidade Metodista de São Paulo 148

$\begin{array}{ll}\text { 3.1.7 Curso de música } & 149\end{array}$

3.1.8 Curso de injeção eletrônica 150

3.2 Algumas reflexões 152

3.2.1 Quem são os atores, o que e como fazem 152

3.2.2 Não à escola, sim ao conhecimento 156

3.2.3 Incidir sobre o presente 157

3.2.4 A falta de sentido como condição 158

$\begin{array}{ll}\text { 3.2.5 Acesso controlado } & 161\end{array}$

3.2.6 Os/as educadores/as e o potencial de controle da educação 164

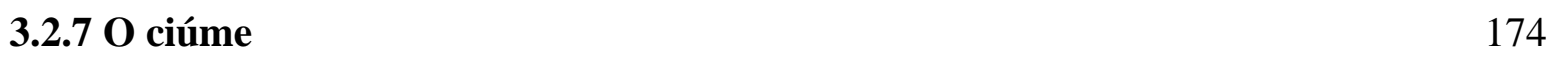

3.3 Algumas conclusões 176

3.3.1 Fragilidade e precariedade das ações 176

3.3.2 Limites e possibilidades 177

$\begin{array}{ll}\text { 3.3.3 Quem controla quem } & 179\end{array}$

\section{CAPÍTULO 4 - AS FORMAS DE PARTICIPAÇÃO NUM}

SISTEMA QUE SE FECHA 180

4.1 Sociedade civil e esfera pública $\quad 181$

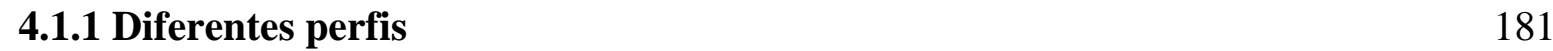

4.1.2 Diversidade entre as ONGs 182

4.1.3 A construção da esfera pública 185

$\begin{array}{ll}4.2 \text { Contestar a prisão } & 187\end{array}$

4.2.1 Direitos humanos no Brasil 187

4.2.2 Construção da insensibilidade 190 
4.3 Múltiplas expectativas

4.3.1 A ausência assinalada

4.3.2 Ambiguidades normatizadas

4.3.2.1 Programa Nacional de Direitos Humanos 195

4.3.3 A participação no Estado de São Paulo 201

4.3.4 A transferência de responsabilidade $\quad 210$

4.4 A mobilização por educação 217

$\begin{array}{ll}\text { 4.4.1 Presença antiga } & 217\end{array}$

4.4.2 Demanda recente 219

4.4.3 Quem paga a conta 223

4.5 Algumas conclusões $\quad 226$

4.5.1 Sociedade civil e esfera pública $\quad 226$

$\begin{array}{ll}\text { 4.5.2 Contestar a prisão } & 227\end{array}$

$\begin{array}{ll}\text { 4.5.3 Múltiplas expectativas } & 227\end{array}$

4.5.4 A mobilização por educação 227

4.5.5 A participação da sociedade civil 228

CONCLUSÕES - EDUCAÇÃO NAS PRISÕES: SINAIS

DE MUDANÇA 230

REFERÊNCIAS 239

$\begin{array}{ll}\text { ANEXOS } & 254\end{array}$ 


\title{
INTRODUÇÃO
}

\section{A EDUCAÇÃO NAS PRISÕES: UM ESTUDO SOBRE A PARTICIPAÇÃO DA SOCIEDADE CIVIL}

\author{
[...] sigue existiendo un nivel muy bajo de investigación. Sigue \\ habiendo una escasez de investigaciones y debates sobre la \\ educación en las cárceles y más particularmente sobre la \\ forma en que los programas educativos se conciben, financian \\ y hacen accesibles a la población penitenciaria. (MUÑOZ, \\ 2009, p. 9).
}

Esta pesquisa propõe a investigação das práticas educativas desenvolvidas por organizações da sociedade civil e pessoas voluntárias no interior do sistema penitenciário do Estado de São Paulo. Tais iniciativas, que se constituem em partilha da responsabilidade entre Estado e sociedade civil, são previstas e estimuladas em normas que versam sobre a educação no ambiente prisional.

Diante da falta de informações sistemáticas acerca dessas parcerias, esta pesquisa teve entre seus objetivos: a caracterização dos tipos de parcerias estabelecidas; a identificação das motivações, intencionalidades e objetivos que regem tais iniciativas; a verificação de diferenças entre as atividades propostas nos presídios masculinos e femininos, entre outros.

\section{A) Justificativa, objetivos e hipóteses}

Mais de 469 mil pessoas, jovens e adultas, encontram-se encarceradas no sistema prisional brasileiro, sendo que aproximadamente $65,5 \%$ delas não concluíram o ensino fundamental e outras $7,7 \%$ são analfabetas. Apesar da demanda potencial para os cursos de educação de jovens e adultos, apenas $8,4 \%$ estudam.

Não há dados nacionais consolidados sobre as atividades educativas empreendidas nos estabelecimentos prisionais. Pesquisas acadêmicas e notícias da imprensa apontam que, sob a denominação de "educação", se encontram tanto atividades de educação não formal geralmente promovidas por pessoas voluntárias, organizações não governamentais (ONGs) e 
entidades filantrópicas e religiosas - quanto cursos classificados como profissionalizantes e, ainda, iniciativas destinadas à elevação da escolaridade.

Conforme registrado na dissertação de mestrado "A educação como um direito humano: a escola na prisão"1 - que pesquisou a oferta, por parte do Estado, de educação escolar à população carcerária do Estado de São Paulo, paralelamente às atividades promovidas pela Fundação Prof. Dr. Manoel Pedro Pimentel - Funap/Secretaria Estadual de Administração Penitenciária -, desenvolvem-se no interior das prisões inúmeras outras atividades, consideradas pelos seus dirigentes de caráter educativo e promovidas por organizações da sociedade civil ou pessoas voluntárias, conforme demonstra o quadro a seguir, identificado na Penitenciária Feminina da Capital, em 2004.

\section{Quadro 1 - Agenda Semanal Escolar}

\begin{tabular}{|c|c|c|c|c|c|c|}
\hline & $2^{a}$ feira & $3^{\text {a }}$ feira & $4^{\mathrm{a}}$ feira & $5^{\mathrm{a}}$ feira & $6^{\mathrm{a}}$ feira & Sábado \\
\hline $\begin{array}{l}\text { Manhã } \\
\text { até } 12 \mathrm{~h}\end{array}$ & - & Ressocialização & - & - & Ressocialização & Teatro \\
\hline $\begin{array}{l}\text { Tarde até } \\
18 \text { horas }\end{array}$ & $\begin{array}{l}\text { Supletivos } \\
\text { Terapia } \\
\text { Terapia } \\
\text { Biscuit } \\
\text { Aeróbica }\end{array}$ & $\begin{array}{l}\text { Supletivos } \\
\text { Terapia } \\
\text { Terapia } \\
\text { Macramê } \\
\text { Samba-Rock }\end{array}$ & $\begin{array}{l}\text { Supletivos } \\
\text { Terapias } \\
\text { Biscuit } \\
\text { Canto Coral } \\
\text { Ponto Cruz }\end{array}$ & $\begin{array}{l}\text { Supletivos } \\
\text { Terapia }\end{array}$ & Supletivos & $\begin{array}{l}\mathrm{AA}^{*} \\
\mathrm{NA}^{* *}\end{array}$ \\
\hline $\begin{array}{l}\text { Noite até } \\
20 \text { horas }\end{array}$ & $\begin{array}{l}\text { Alfa - I e II } \\
\text { Supletivos } \\
\text { Informática } \\
\text { Espanhol }\end{array}$ & $\begin{array}{l}\text { Alfa - I e II } \\
\text { Supletivos } \\
\text { Informática } \\
\text { Inglês }\end{array}$ & $\begin{array}{l}\text { Alfa - I e II } \\
\text { Supletivos } \\
\text { Informática } \\
\text { Espanhol }\end{array}$ & $\begin{array}{l}\text { Alfa - I e II } \\
\text { Supletivos } \\
\text { Informática } \\
\text { Inglês }\end{array}$ & $\begin{array}{l}\text { Alfa - I e II } \\
\text { Supletivos } \\
\text { Informática }\end{array}$ & \\
\hline
\end{tabular}

* Alcoólicos Anônimos

** Narcóticos Anônimos

Inglês Iniciantes: quintas-feiras

Espanhol Iniciantes: segundas-feiras

Informática: turma da noite - terças/quintas-feiras

Informática: segundas/quartas-feiras

A temática da educação de pessoas jovens e adultas privadas de liberdade, em geral, apenas muito recentemente vem sendo tomada como objeto de pesquisas acadêmicas, conforme observado na pesquisa bibliográfica empreendida no processo de realização desta pesquisa. De acordo com uma série de estudos do tipo "Estado da Arte"2, que buscava identificar trabalhos acadêmicos sobre a modalidade "educação de jovens e adultos", entre 1975 e 2000 - 25 anos -, não houve o registro de nenhuma dissertação de mestrado ou tese de doutorado que abordasse o tema das práticas educativas - formais ou não formais -

\footnotetext{
${ }^{1}$ Desenvolvida pela autora desta tese, no programa de Pós-Graduação da Faculdade de Educação da Universidade de São Paulo (FEUSP), sob a orientação da Prof ${ }^{a}$ Dr $^{a}$ Flávia Inês Schilling, com defesa realizada em outubro de 2005.

${ }^{2}$ HADDAD, 1987; HADDAD; FREITAS, 1988; HADDAD; SIQUEIRA, 1986, 1988; HADDAD, SIQUEIRA, FREITAS, 1987, 1989a, 1989b; RIBEIRO, V.M., 1992; HADDAD et al., 2002; HADDAD, 2004.
} 
desenvolvidas no interior das unidades prisionais. Apenas a partir de 2000 foram identificadas dissertações de mestrado e, na sequência, em 2002, foram registradas as primeiras teses de doutorado sobre o tema (Tabela 1).

\section{Tabela 1}

Teses e Dissertações “Educação nas Prisões” - 2000 a $2008{ }^{3}$

\begin{tabular}{|l|l|l|l|l|l|l|l|l|l|l|}
\hline Ano & $\mathbf{2 0 0 0}$ & $\mathbf{2 0 0 1}$ & $\mathbf{2 0 0 2}$ & $\mathbf{2 0 0 3}$ & $\mathbf{2 0 0 4}$ & $\mathbf{2 0 0 5}$ & $\mathbf{2 0 0 6}$ & $\mathbf{2 0 0 7}$ & $\mathbf{2 0 0 8}$ & Total \\
\hline Dissertações & 1 & 2 & 3 & 3 & 2 & 3 & 3 & - & 1 & $\mathbf{1 8}$ \\
\hline Teses & - & - & 2 & - & - & 1 & - & 2 & - & 5 \\
\hline Total & $\mathbf{1}$ & $\mathbf{2}$ & $\mathbf{5}$ & $\mathbf{3}$ & $\mathbf{2}$ & $\mathbf{4}$ & $\mathbf{3}$ & $\mathbf{2}$ & $\mathbf{1}$ & $\mathbf{2 3}$ \\
\hline
\end{tabular}

Fonte: Banco de Teses e Dissertações da Capes; sistemas de buscas na internet.

Nos trabalhos identificados entre 2000 e 2008, não há nenhum que tenha como temática a participação da sociedade civil na oferta das práticas educativas em prisões. $\mathrm{O}$ foco das investigações acerca da educação em prisões tem sido centrado no seu potencial de ressocialização, reeducação ou reinserção social, argumentos oficialmente utilizados para justificar a própria existência das prisões, e enunciado na Lei de Execução Penal (Lei Federal 7.210/84): “A execução penal tem por objetivo efetivar as disposições de sentença ou decisão criminal e proporcionar condições para a harmônica integração social do condenado e do internado".

Haddad (2009), investigando a produção científica nas áreas de Educação, Ciências Sociais e Serviços Sociais sobre a temática Educação Não Escolar de jovens e adultos no período de 1998 a 2006, não localizou nenhum estudo sobre tais práticas desenvolvidas no ambiente prisional.

Os trabalhos que analisam as práticas educativas no ambiente prisional demonstram que tais termos têm adquirido diferentes significados, mas, de maneira geral, as expectativas da educação na prisão recaem sobre o futuro a ser construído com a conquista da liberdade e, nunca, como possibilidade de alterar as condições de vida presente; dessa perspectiva, a máxima pretensão de intervenção no presente é, em relação às pessoas analfabetas, a possibilidade de aprenderem a escrever cartas - instrumento fundamental de comunicação para os prisioneiros.

No entanto, durante as entrevistas realizadas na Penitenciária Feminina da Capital (Graciano, 2005) chamou a atenção a insistente e espontânea referência ao curso "Promotoras Legais Populares", que, segundo as alunas, foi muito útil para esclarecer acerca de seus direitos, inclusive aqueles que devem ser assegurados na prisão.

\footnotetext{
${ }^{3}$ Ver relação completa no Anexo 1 .
} 
Há, nessa iniciativa, uma evidente alteração de sentido para a prática educativa e seu potencial de ressocialização, ao fornecer informações e estimular reflexões capazes de interferir nas atuais condições de vida daquelas alunas. Tal perspectiva demonstra que a intencionalidade das práticas educativas empreendidas no interior do ambiente prisional pode variar em função dos agentes promotores.

No caso citado, a divergência se coloca entre a perspectiva anunciada pelo Estado educação como preparação para o futuro - e aquela desenvolvida por uma organização da sociedade civil - formação para o exercício de direitos, inclusive no momento presente. Dada a diversidade de atores e práticas identificadas, é pertinente supor que a intencionalidade também seja variada, mas não existem informações que permitam identificar quais são, como se relacionam entre si nem em que medida constituem ou dão significado à função social da pena.

A convivência no ambiente prisional, entre as ações educativas protagonizadas por agências estatais e organizações e pessoas da sociedade civil, também remete à compreensão desse fenômeno ao campo de análise sobre a relação entre Estado e sociedade civil na formulação e implementação de políticas públicas.

De maneira geral, a relação entre sociedade civil e Estado quanto à concepção, implementação, gestão e execução de ações públicas tem sido analisada sob dois diferentes aspectos. De um lado, a ampliação dos canais de participação e controle social sobre as ações do Estado e, de outro, a transferência da responsabilidade pela garantia de direitos universais para a sociedade civil, que não possui condições estruturais para realizá-la. É o que Di Pierro (2001) classifica como ambiguidade inerente a esta relação.

O acompanhamento regular da página eletrônica da Secretaria de Administração Penitenciária (SAP), órgão estatal responsável pela organização e gestão das prisões, traz, por exemplo, informações muito diferenciadas sobre a presença de instituições civis no cotidiano das unidades. São relatos de atividades culturais, palestras, cursos e até a transferência total da administração de algumas unidades para tais organizações.

Essas informações não são formuladas de maneira sistematizada e abrangente, de forma a permitir a compreensão, e o controle social, sobre a celebração dessas parcerias. São notas jornalísticas, apresentadas com formato promocional, de atividades pulverizadas e pontuais, que não possibilitam identificar quais os critérios adotados pelo poder público no estabelecimento da relação com a sociedade civil; tampouco apontam quais os objetivos e intencionalidades das ações empreendidas. 
Parece não haver orientação específica por parte do órgão responsável pela administração das penitenciárias paulistas para a realização das atividades educativas. É permitida - e até formalmente estimulada - a diversidade de ações.

Essa aparente flexibilidade, que induz à interpretação que o Estado é permeável à intervenção da sociedade civil na organização do sistema prisional paulista, deposita nas direções das unidades prisionais a total responsabilidade sobre a administração das penitenciárias, inclusive no que se refere à proposição, realização e acesso às atividades.

Tendo em vista o grau de "autonomia" (ADORNO, 1991) conferido às administrações das unidades, que por vezes resulta inclusive na impossibilidade de implementação de ações públicas propostas pela administração central da educação penitenciária, é bastante razoável supor que as parcerias se dão tanto na esfera das políticas estaduais quanto na administração particular de cada unidade.

Possivelmente, o órgão central responsável pela administração penitenciária não tenha registro sobre todas as parcerias estabelecidas nas unidades prisionais, por isto, a compreensão da natureza, grau e intensidade dessas relações, bem como o seu papel na educação ofertada nos presídios no sentido de intervir na vida dos educandos e na gestão penitenciária, depende da investigação nos dois níveis da gestão penitenciária: a central política de Estado - e as periféricas - ações administrativas nas unidades.

Sem parâmetros orientadores e com a fragmentação de ações e suas respectivas informações, a sociedade civil, ainda que executora de atividades pontuais, não tem condição de exercer controle ou intervir na organização do sistema prisional.

O foco de investigação proposto neste trabalho justifica-se tanto pela ausência de informações e reflexões empreendidas sobre o tema quanto pela relevância social de estudos que contribuam para a compreensão do funcionamento das prisões brasileiras.

Utilizado pelo poder público como a principal forma de repressão às atividades e pessoas socialmente consideradas criminosas, o encarceramento de seres humanos pelo Estado é pouco conhecido da sociedade. Conhecer e analisar suas regras de funcionamento e adequação para alcançar a função social da pena, formulada na Lei de Execução Penal, constituem-se em contribuição essencial tanto para orientar a ação do poder público como para fornecer elementos e estimular o necessário debate social sobre a função e a organização das prisões no País.

Nesse sentido, esta pesquisa teve como objetivo geral investigar a participação da sociedade civil na realização dos direitos educativos da população carcerária do Estado de São Paulo. Da mesma forma, adotou como objetivos específicos: 1) Caracterizar os tipos de 
parceria que vêm sendo estabelecidas entre o governo do Estado de São Paulo e as organizações da sociedade civil, no âmbito da Secretaria Estadual de Administração Penitenciária; para a promoção de atividades educativas. 2) Caracterizar as ações de voluntariado, identificadas como educativas no interior do sistema prisional. 3) Caracterizar as organizações da sociedade civil que realizam atividades educativas no sistema prisional, identificando sua missão institucional, abrangência de atuação e objetivo das práticas realizadas. 4) Verificar a influência das práticas educativas promovidas pela sociedade civil no presente de suas/seus educandas/os.

As considerações finais da pesquisa permitirão testar três hipóteses iniciais. A primeira delas é que a ausência de diretrizes nacionais que orientem as práticas educativas mantém o ordenamento e a gestão do sistema prisional no âmbito da iniciativa privada. A segunda hipótese é que Estado e sociedade civil têm diferente compreensão sobre o sentido das práticas educativas empreendidas no interior das prisões; ocupar o tempo livre é a principal motivação do Estado para permitir a entrada da sociedade civil nas prisões, e esta, por sua vez, crê que sua ação pode contribuir com o desenvolvimento humano. Por fim, a terceira é que a diversidade, irregularidade e parcialidade das ações empreendidas pela sociedade civil, ordenadas pelo Estado, garantem a manutenção da prisão como espaço de contenção privado.

\section{B) Material e método}

Conforme apontado anteriormente, a gestão do ambiente prisional caracteriza-se por múltiplos comandos. De um lado - do lado de fora dos muros -, há determinações inscritas em normas jurídicas e orientações advindas de órgãos governamentais; de outro lado - o lado de dentro dos muros -, há a autonomia das direções de unidades, as práticas dos funcionários e os arranjos da própria população carcerária.

Nesse contexto, o primeiro passo foi o levantamento e a análise de documentos oficiais sobre o estabelecimento de parcerias entre o Estado e as organizações da sociedade civil, tomando como fonte a Secretaria Estadual de Administração Penitenciária (SAP).

A fim de compor um cenário mais amplo, com informações de âmbito nacional, sobre a relação entre sociedade civil e Estado, outras duas fontes foram consideradas. A primeira delas são as agências governamentais responsáveis pela orientação da oferta de educação nas prisões na esfera nacional - Ministério da Justiça, por meio do Departamento de Política Penitenciária, e Ministério da Educação. 
Outra fonte adotada foi o noticiário da imprensa escrita, com levantamento de material publicado em 75 jornais de todos os Estados brasileiros, no período de 2002 a 2008, utilizando o cruzamento das palavras: educação, escola, prisão, penitenciária. O levantamento foi realizado pela empresa Resumo da Mídia, especializada na elaboração de clippings eletrônicos da mídia impressa.

Dado o grau de desagregação das informações e a ausência de centralização das ações orientadoras da gestão prisional, o quadro de informações oficiais e veiculadas na imprensa será complementado com o levantamento das atividades educativas, feito diretamente em duas unidades prisionais do Estado de São Paulo.

A pesquisa de campo foi realizada na Penitenciária "José Parada Neto", de regime fechado, destinada à população masculina, que em agosto de 2008 contava com 1.114 internos. E na Penitenciária Feminina da Capital, de regime fechado, destinada à população feminina, que em setembro de 2008 tinha 700 internas.

As atividades e seus respectivos agentes responsáveis identificados foram tomados como fontes para as entrevistas realizadas na segunda etapa da pesquisa.

Foi adotada a técnica de entrevista compreensiva, em virtude da adequação de suas características aos objetivos da pesquisa: "a ausência de rigidez na estrutura da entrevista compreensiva permite a construção da problemática de estudo durante seu desenvolvimento e nas suas diferentes etapas (...) as questões previamente definidas podem sofrer alterações conforme o direcionamento que se quer dar à investigação" (ZAGO, 2003, p. 295).

Todas as pessoas entrevistadas foram convidadas a autorizar a utilização das informações nesta pesquisa, mediante a assinatura do "termo de consentimento livre e esclarecido". Ainda assim, a identidade das pessoas entrevistadas será preservada, com o objetivo de isentá-las de possíveis represálias por suas declarações. Dessa forma, ao longo do texto, elas serão identificadas com apenas uma inicial de seu nome completo, marcada em itálico.

As visitas às unidades prisionais permitiram identificar as seguintes atividades de educação não formal: curso "Promotoras Legais Populares"; projeto "Quem Somos Nós"; projeto "Leitura Livre/ Leitura Ativa"; "Grupo de Diálogo Universidade Cárcere e Comunidade" (GDUCC); curso de música; curso de injeção eletrônica; oficinas de prevenção às DST/Aids; oficina de capacitação na produção de programas de rádio. No caso das oficinas de prevenção DST/Aids e de capacitação de programas de rádio, não foi possível localizar os responsáveis por sua realização, portanto, não foram feitas entrevistas que permitissem utilizar a experiência para a compreensão dos aspectos políticos e pedagógicos das ações. No 
entanto, a forma de sua inserção trouxe interessantes elementos para a compreensão do caráter pontual, fragmentado e precário das ações.

As outras experiências foram interpretadas e discutidas por meio das informações e reflexões trazidas por educadoras e educadores envolvidos, além de seus dirigentes ou pessoas responsáveis.

Também foram entrevistados dois gestores responsáveis pela execução penal, em diferentes instâncias - um deles ainda em exercício e, outro, já afastado das funções públicas. Também foram entrevistados quatro funcionários responsáveis pela realização das atividades educativas nas prisões, além de um psicólogo do sistema.

Foram feitas duas entrevistas com pessoas internas às penitenciárias, que participam de pelo menos uma das atividades identificadas, bem como uma entrevista com uma pessoa egressa recentemente do sistema penitenciário.

Três pessoas, ativistas em organizações de defesa dos direitos das pessoas encarceradas, foram entrevistadas formalmente para a compreensão de sua inserção no campo da educação nas prisões.

Por fim, este trabalho de pesquisa - reflexões e conclusões produzidas - foi influenciado por inúmeras conversas informais estabelecidas com pessoas egressas, educadoras e educadores, funcionários, dirigentes ou ex-dirigentes de unidades prisionais, ativistas de direitos humanos e também do campo da educação.

Foram formulados diferentes roteiros de entrevistas para cada um dos atores envolvidos nos processos educativos identificados (ver Anexo 2).

A classificação das atividades identificadas foi feita com base nas categorias “educação formal", "educação não formal" e "educação informal”, conforme proposto por Coombs $^{4}$ (1975 apud TRILLA, 2008, p.18), que propõe uma delimitação entre os diferentes tipos de educação. A educação formal é constituída pelo sistema educativo "altamente institucionalizado, cronologicamente organizado e hierarquicamente estruturado, que se estende desde os primeiros anos da escola primária até os últimos anos da universidade”. A educação não formal seria "toda atividade organizada sistemática, educativa, realizada fora do marco do sistema oficial, para facilitar determinadas classes de aprendizagem a subgrupos específicos da população, tanto adultos quanto crianças". E a educação informal foi classificada como "um processo que dura toda a vida em que as pessoas adquirem e

\footnotetext{
${ }^{4}$ COOMBS, P.H; Ahmed, M. A luta contra a pobreza rural. Contribuição da educação não formal. Madri, Ed. Tecnos, 1975.
} 
acumulam conhecimentos, habilidades, atitudes e modos de discernimento mediante as experiências diárias e sua relação com o meio ambiente".

Essas categorias foram utilizadas a fim de apreender aspectos como: ator social responsável por sua realização; orientações do Estado; objetivos; público prioritário e mecanismos de seleção do público; relação. Apesar de esta pesquisa ter como objeto de análise as práticas de educação não formal em prisões, também foram verificadas as relações estabelecidas entre estas atividades e as de outro tipo - educação formal e educação informal.

A intencionalidade das ações em relação à temporalidade dos resultados esperados foi tomada como uma perspectiva central de análise. Interessou compreender se as atividades são orientadas na perspectiva da reinserção ou reintegração social - ou seja, se o aprendizado terá efeito apenas fora da prisão - ou se busca provocar conhecimentos e experiências possíveis de serem exercitados na prisão.

Os agentes promotores identificados foram: pessoas voluntárias leigas e pessoas voluntárias orientadas por missão religiosa; universidades e organizações da sociedade civil. As universidades tiveram seu trabalho considerado de duas maneiras. A primeira, vinculado a parcerias institucionais entre a universidade e os governos e, a segunda, aquelas relativas a projetos de pesquisas de estudantes, seja para Trabalhos de Conclusão de Curso (TCC), estágios obrigatórios ou estágios voluntários.

As organizações da sociedade civil foram consideradas com base nas reflexões propostas por Dagnino (2002), Costa (2002) e Gohn (2008), entre outros, que apontam a pluralidade de organizações que compõe esta denominação, bem como as transformações ocorridas em sua prática desde o período da ditadura militar no País.

Conforme exposto anteriormente, a pesquisa combinará uma série de instrumentos. A perspectiva quantitativa foi necessária para compor o cenário do universo estudado. A perspectiva qualitativa é entendida como aquela capaz de incorporar os significados atribuídos pelos sujeitos aos seus atos e as relações que estabelecem a partir de então. Como características favoráveis ao estudo qualitativo, temos o seu desenvolvimento em um plano aberto e flexível, o foco numa realidade complexa e contextualizada e a capacidade de lidar com as diferentes subjetividades. Esta é uma contribuição importante trazida por Bourdieu (1997) ao abordar o tema da comunicação na relação pesquisador/objeto de pesquisa, focalizando as interações entre os sujeitos que participam como entrevistadores e entrevistados. Para o autor, ainda que a relação de pesquisa tenha as suas especificidades como relação social, esta troca de experiência também exerce efeitos que precisam ser identificados e analisados. 
Os referenciais teóricos foram tomados como instrumento de compreensão da realidade verificada. Dentre eles, conformando um primeiro bloco de análise, a situação atual das prisões no Brasil foi interpretada tomando como referencial de análise as noções conceituais de "prisão disciplinar", "prisão pós-disciplinar", "sociedade do controle", "previdenciarismo penal"; "ideal de reabilitação", entre outros. Entre os autores considerados nesta etapa estão Foucault (1986; 1988; 1979; 2005); Soares e Ilgenfritz (2002); Rusche e Kirchheimer (2004); Schilling (1996 e 2008); Goffman (1996); Salla (1997; 2007); Bauman (1999); Salla, Gauto e Alvarez (2006); Koerner (2006); Garland (2008); Chantraine (2006); Christie (1998); Cunha (2005); Rose (1996).

No segundo bloco de reflexões, dialogando com as normas que regulam ou estimulam a educação em prisões, foram utilizados os conceitos de educação formal, não formal e informal, assim como a sua relação com os conceitos de educação não escolar, educação popular e educação para o desenvolvimento humano. Neste bloco, os referenciais teóricos foram: Gohn (2008); Trilla (2008); Sen, Amartia (2000); Foucault (1986); Soares e Ilgenfritz (2002); Rusche e Kirchheimer (2004); Schilling (1996 e 2008); Haddad (2009).

O terceiro bloco de reflexões refere-se à compreensão dos debates existentes em torno dos conceitos de sociedade civil, sobretudo no que se refere à sua caracterização, composição, formas de atuação e múltiplas relações com o Estado. As informações apreendidas das organizações e pessoas identificadas na pesquisa de campo e as informações oficiais forneceram o material empírico para a compreensão dos conceitos apresentados anteriormente. Bobbio (1982); Costa (2002); Dagnino (2002); Di Pierro (2001); Genro (1996); Trilla (2008); Ghanem (2008); Gohn (2008) e Haddad (2004) estão entre os autores das reflexões tomadas como parâmetro de análise.

O quarto conjunto de análises foi destinado à compreensão da participação da sociedade civil nas prisões e no campo educacional. Para tanto, foi feito um resgate da história dessa atuação, tarefa nada simples, uma vez que já foi identificada a inexistência de pesquisas sobre o tema. Neste contexto, o desafio colocado foi o de identificar as diferentes possibilidades de atuação, buscando relacionar com as administrações públicas, para compreender mecanismos de estímulo ou cerceamento de sua atuação. Novamente, as reflexões das pessoas entrevistadas foram tomadas como fonte de informação e material de análise para a compreensão deste campo. Os referenciais teóricos serão: Foucault (1986; 1988; 1979; 2005); Adorno (1991; 2001); Salla (2007); Gauto e Alvarez (2006); Koerner (2006); Garland (2008); Benevides (1994, 1996); Dallari (2004); Comparato (2003); Dallari (2004), entre outros. 
Por último, o quinto bloco de análise contém as conclusões do estudo, formuladas com base nos objetivos e hipóteses propostos.

\section{C) O campo pesquisado - Breve descrição, algumas constatações}

O processo de solicitação de autorização para acompanhar as atividades nas unidades prisionais teve início no primeiro semestre de 2008, por meio de contato com a equipe técnica da Funap. Após contatos telefônicos, foi agendada uma reunião com três pessoas da equipe técnica, oportunidade na qual apresentei o projeto de pesquisa. A conversa foi bastante longa, e a equipe se mostrou bastante solícita em colaborar na viabilização da entrada, bem como, diante do interesse demonstrado no tema, acordamos discutir alguns textos coletivamente. Ao final, ficou estabelecido que o grupo faria os contatos e agendamentos necessários às visitas às unidades. Por sugestão da equipe da Funap, a pesquisa de campo seria ampliada, de forma que fossem observadas também unidades de regime semiaberto.

Depois de quase dois meses, período no qual entrei em contato várias vezes e obtive respostas evasivas, como falta de tempo para fazer os contatos ou falta de agenda, busquei novos caminhos de entrada.

Por meio de um contato telefônico com uma das pessoas responsáveis pelas atividades educativas na Penitenciária Feminina da Capital, obtive a informação de que deveria encaminhar a Hugo Berni Neto, coordenador da Coordenadoria das Unidades Prisionais São Paulo e Grande São Paulo, ofício da Faculdade de Educação da USP, assinado pela Prof ${ }^{\mathrm{a}}$ Dr $^{\mathrm{a}}$ Flavia Schilling, explicando os objetivos da pesquisa e solicitando autorização para visitar as penitenciárias.

O documento foi protocolado em 27 de agosto e, por cinco dias, telefonei para saber a resposta. Em uma das tentativas consegui falar com uma funcionária, que se identificou como secretária de Hugo Berni, e, depois de lhe explicar o teor da solicitação - que ainda não havia chegado até o gabinete -, ela me informou que o pedido deveria ser feito diretamente à Secretaria de Administração Penitenciária.

$\mathrm{Na}$ tentativa de descobrir a quem endereçar o pedido, primeiro foi informado que deveria ser encaminhado à Assessoria de Imprensa. Assim foi feito, mas tendo estranhado a orientação, fiz novo contato e falei com o gabinete do secretário Antonio Ferreira Pinto. A orientação foi que o pedido deveria ser encaminhado diretamente para aquela instância, por meio de correio eletrônico. Dois dias depois, em 5 de setembro, recebi, também por correio 
eletrônico, a autorização e os contatos com as pessoas responsáveis pelas atividades de educação nas Penitenciárias Feminina da Capital e José Parada Neto.

\section{Penitenciária Parada Neto}

\section{$\underline{1^{a} \text { visita }}$}

Fui muito bem recebida pelos funcionários responsáveis pela diretoria de Educação, ambos agentes penitenciários que cursaram, respectivamente, Pedagogia e Direito, e foram promovidos a estas funções. Apenas para elucidar, a funcionária cursou Direito e o funcionário, Pedagogia.

Nessa primeira visita à Parada Neto, foram então feitas entrevistas com as pessoas responsáveis pelas diretorias de Educação e de Reintegração Social.

\section{$\underline{2^{a} \text { visita }}$}

Cheguei no horário, mas meu nome não estava na listagem de autorizações disponível aos agentes penitenciários responsáveis pela portaria, embora tivesse agendado e combinado com a diretoria de Educação. Fiquei esperando cerca de 20 minutos até conseguir autorização. Passei por duas "portarias" e, na terceira, apesar de uma das agentes afirmar reiteradas vezes que eu havia estado lá no dia anterior e tinha autorização para entrar, fiquei esperando até virem me buscar. Pela primeira vez, passei pela revista - as agentes foram muito gentis.

Entrei com o agente responsável pela segurança da escola e a estagiária vinculada à Funap. Ficamos aguardando por quase uma hora na sala da diretoria de Educação. Esperávamos os integrantes do GDUCC chegarem, para entrarmos todos juntos na escola. Não pude deixar de ouvir a conversa, via rádio, entre a diretoria de Educação e os agentes responsáveis pela portaria, a respeito da necessidade de a equipe do GDUCC passar pela identificação.

Quando os integrantes do GDUCC chegaram, comentaram conosco que o atraso foi devido à determinação de todos passarem pelo processo da "revista" e porque o nome de um deles não estava na lista. 
Finalmente fomos para a escola. Acompanhei o trabalho do GDUCC - era o segundo encontro com uma nova turma, mas não foi possível entrevistar os responsáveis naquele momento. A entrevista foi feita posteriormente, fora da unidade.

Participaram do encontro estudantes e profissionais das áreas de Direito e Psicologia, além de aproximadamente 20 internos com idades variadas. Utilizo o termo aproximadamente pois não fiz nenhum tipo de anotação ou registro - este foi o acordo feito para participar do encontro. $\mathrm{O}$ tema em debate era a prisão e, na conversa, os estudantes e profissionais do Direito argumentavam que a prisão é ineficiente e injusta, feita apenas para as pessoas socialmente vulneráveis. E os internos contra-argumentavam que era justo estarem ali, pois de fato tinham "errado" e tinham que pagar.

Chamou a atenção a desigualdade da situação - estudantes de classe média (assim se definiam), da universidade pública, todos brancos, desqualificando e criticando a prisão. E os presos, pobres, muitos negros, jovens, afirmando que a prisão estava sendo uma oportunidade de aprendizado, sobretudo pela conversão às igrejas evangélicas. Foram vários os relatos de "encontro com Jesus".

Era aniversário de um dos rapazes, jovem negro, $A$, que completava 23 anos. Ele nos presenteou com um rap de louvor a Cristo e depois cantamos "Parabéns"; nos ofereceram café, e a equipe do GDUCC teve que sair correndo - literalmente -, pois seu horário tinha acabado. Eu poderia ficar até o final do expediente, às $17 \mathrm{~h} 30$.

Sempre com a ajuda de um dos agentes e da estagiária vinculada à Funap, entrevistei a professora de música, voluntária, vinculada à Igreja Batista; um dos internos que participa do GDUCC; o professor voluntário de Espanhol, também interno.

O tempo acabou e tive que sair correndo - seria necessária outra autorização para retornar e seguir com as entrevistas. No entanto, dadas as dificuldades verificadas nessa visita, tanto em relação à demora em entrar quanto ao reduzido tempo para as entrevistas, a opção foi efetuar entrevistas com as pessoas responsáveis pelas atividades em outros espaços, agendando encontros fora da prisão.

Quanto aos educandos, avalio como ineficaz a tentativa de entrevistá-los na prisão. Não pude ficar a sós com eles - as entrevistas foram feitas na "Sala dos Professores", com a presença de vários monitores sentenciados. Fomos interrompidos inúmeras vezes por funcionários, e, conforme já apontado por outras pessoas que desenvolveram pesquisa no ambiente prisional, as respostas pareciam formuladas para afirmar a importância das atividades ofertadas, conforme será apresentado em outro momento da pesquisa. 
Esta constatação também foi considerada na perspectiva dos processos educativos verificados na prisão, que, para esta pesquisa, serão tomados com base em três categorias, como já informado: processos de educação formal, não formal e informal. Neste caso, aceitando a reflexão citada anteriormente, o comportamento dos educandos seria o resultado de processos educativos informais, estabelecidos na relação com os funcionários da instituição, mas também com seus pares, com quem compartilham códigos de conduta, estabelecidos nas relações de poder dos grupos ou "partidos", com vêm sendo chamados.

Essa última dimensão - a relação entre os pares -, e suas consequências para a organização interna das prisões, foi tema de comentários e reflexões por grande parte das pessoas entrevistadas e também nas conversas informais com pessoas que, por uma ou outra razão, frequentam as unidades visitadas.

Não será revelada a área de atuação dessas pessoas para preservar sua identidade, uma vez que não pedi autorização para utilizar o conteúdo de suas falas, que não foram gravadas. Trata-se de conversas informais, porém, que foram de extrema importância para perceber que era inútil prosseguir nas entrevistas com os educandos, porque integram grupos organizados e suas atitudes e opiniões são controladas, assim como controlam outras pessoas. As atividades realizadas nas unidades visitadas são autorizadas por estes grupos e, portanto, sua avaliação deve ser positiva, sempre.

De acordo com as informações coletadas, os diferentes grupos têm posicionamentos contrários em relação às atividades realizadas por "pessoas de fora". Alguns autorizam e até apóiam as iniciativas, inclusive garantindo a segurança. Outros grupos preferem não ter circulação de pessoas externas ao ambiente prisional, e proíbem sua entrada. Como será demonstrado ao longo da apresentação da pesquisa, estas informações confirmam características verificadas no que tem sido denominada "prisão pós-disciplinar".

\section{Penitenciária Feminina da Capital}

\section{$\underline{1^{a} \text { visita }}$}

Cheguei no horário agendado - 9 horas -, mas aguardei por quase uma hora na Portaria, pois meu nome não estava na lista, e a pessoa responsável pelas atividades de educação se atrasou. Esse período de espera é sempre muito interessante, pois se fica ouvindo as conversas entre os/as agentes penitenciários responsáveis pelo controle da Portaria e pode-se ver o recebimento do "jumbo" - objetos ou alimentos trazidos às presas. 
As conversas indicam grande animosidade entre o pessoal da segurança e o administrativo. Muitas são as críticas e ironias sobre horários não cumpridos e displicência com o trabalho.

Os funcionários da Portaria tentaram que outra pessoa autorizasse minha entrada e, depois de muitos telefonemas, finalmente a assistente da diretora da Educação autorizou que eu ficasse esperando na sua sala, mas não pude levar o gravador, porque a autorização emitida pela Secretaria de Administração Penitenciária não foi encontrada.

Quando chegou, a diretora da educação também não encontrava a autorização e ficou revirando inúmeras vezes as mesmas pastas, enquanto criticava o pessoal da segurança e suas colegas. Um clima muito ruim de intriga, e foi impossível não estabelecer comparação com as observações feitas em 2004, durante a pesquisa de campo para o Mestrado, naquela mesma unidade.

De fato, o ambiente está muito mais "fechado". No período anterior, eu pude circular entre o setor de administração e a escola, assisti a aulas em diferentes períodos, entrevistei educandas em locais reservados, conversei e entrevistei livremente funcionários, inclusive a diretora da unidade.

Dessa vez, depois de perder um tempo enorme com a busca da autorização, a diretora de Educação me apresentou para a diretora da escola, que me conduziu até o prédio, já conhecido.

Conversamos longamente, mapeando as atividades que poderiam interessar à pesquisa. Não gravamos entrevista, pois era um dia muito agitado, sexta-feira, reestreia do programa de rádio, e o equipamento, recentemente recuperado, estava apresentando falhas na transmissão.

A diretora corria de um lado para o outro tentando encontrar a frequência para a transmissão. O resultado do mapeamento das atividades desenvolvidas foi o seguinte: projeto “Quem somos nós”, desenvolvido pelo Instituto Terra, Trabalho e Cidadania (ITTC); Música, e Teatro (Funap); Alcoólico e Narcóticos Anônimos; projeto Leitura Livre (Fundação Escola de Sociologia e Política); e xadrez, interna da PFC.

Combinei o retorno para 3 de outubro, no período da tarde, para acompanhar um encontro do projeto Leitura Livre e entrevistar algumas pessoas. 
$\underline{2^{a} \text { visita }}$

Quando cheguei, no final da tarde, a diretora da escola estava saindo. Fiquei na escola acompanhando o trabalho de G., graduado em Biblioteconomia, responsável pelo projeto Leitura Livre. Eram cerca de dez mulheres na sala, que discutiam a letra de uma música, apresentada na sessão anterior. O tema da conversa recaiu sobre sua permanência na prisão, as razões que as trouxeram para ali, possibilidades na saída. Não havia exatamente um tema, mas falas desconexas entre si...

Não foi possível fazer as entrevistas naquele dia, e a ideia era retornar. Aproveitei a visita para conversar com pessoas conhecidas do período do Mestrado, e as informações sobre a atuação dos grupos organizados se repetiram, revelando talvez mais crueldade, maior interferência no ambiente escolar, impossibilidade de conversas livres. Havia cautela com as palavras, não era mais possível fechar a porta da sala - como havia sido possível na pesquisa do Mestrado, para as entrevistas. Como assinalado anteriormente, a opção foi buscar as entrevistas fora, e abri mão das conversas com as educandas internas.

E., que participou do Leitura Livre, foi entrevistada quando já egressa do sistema. Nosso encontro foi viabilizado por G., que havia sido procurado pela moça, que, recém-saída da prisão, buscava orientação para regularizar alguns documentos.

No início de 2009, fui procurada pela diretora da escola, que me informou ter pedido transferência para outra unidade e, também neste caso, a entrevista foi efetuada em outro espaço.

\section{D) Notas para orientar o percurso}

Antes de iniciar a apresentação dos dados, informações e reflexões que conformam esta pesquisa, é preciso considerar que se trata, conforme já salientado, de um tema sobre o qual existem poucas referências teóricas e que grande parte dos dados tomados para análise referem-se ao presente ou fazem parte de um passado muitíssimo recente. Assim, reforça-se as ponderações metodológicas de Garland (2008, p. 70): "Qualquer análise sobre eventos recentes e sobre seu significado estrutural deve ser levada a termo com certo grau de cuidado".

Entre as regras metodológicas que o autor considera como básicas para assegurar os cuidados relacionados à análise de fatos recentes estão: 
Não confundir movimentos de curta duração com mudança estrutural [...] Não confundir discurso com ação [...] Não considerar que o discurso seja inconsequente, pois a retórica política e as representações oficiais acerca do crime e dos criminosos têm um significado simbólico e uma eficácia prática que efetivamente geram consequências sociais [...] Não confundir meios com fins (...). Não unificar questões distintas [...] Não perder de vista o longo prazo [...]" (GARLAND, 2008, p. 70-71).

Admitindo que essas considerações são referenciais permanentes no desenvolvimento desta pesquisa, iniciamos o percurso seguindo como roteiro os blocos de reflexões apresentados anteriormente. 


\section{CAPÍTULO 1 - A EDUCAÇÃO NA PRISÃO QUE SE TRANSFORMA}

Dizem-nos que a justiça está sobrecarregada. Nós bem o vemos. Mas, e se foi a política que a sobrecarregou? Dizem-nos que as prisões estão superlotadas. Mas, e se foi a população que foi superaprisionada? (FOUCAULT; Manifesto do GIP, 1971).

A educação é direito público, subjetivo, garantido em normas nacionais e internacionais. Apesar da indivisibilidade entre os direitos humanos, alguns autores consideram que o direito à educação tem uma característica peculiar: possibilita e potencializa os indivíduos na reivindicação dos outros direitos (COOMANS, 1999). Donnely e Howard (1988, p. 234-235) 5 seguem a mesma visão: "A chave para a ação social em defesa de direitos é uma sociedade educada, capaz de disseminar seus ideais e se organizar em defesa de direitos."

Desde 1948, inúmeros tratados internacionais e normas nacionais foram elaborados afirmando a universalidade dos direitos humanos, entre eles, a Educação. No mesmo sentido, foram produzidas outras tantas normas, estabelecendo os direitos educativos das pessoas que vivem em prisões.

Este capítulo inicial tem por objetivo apresentar as diversas proposições acerca do significado da educação em prisões, contidas nas normas nacionais e internacionais que versam sobre o tema buscando apoio nas considerações de Comparato (1989 e 2004), Munõz (2009), Sen (2000), Claude (2005), entre outros.

A seguir, propõe analisar os conceitos de educação formal, educação não formal e informal, buscando compreender como se concretizam no espaço prisional, com base nos conceitos e reflexões de Trilla (2009), Manheim (1962), Silva et al. (2009), Gohn (2008), entre muitos.

Para auxiliar na identificação do que vem a ser educação nas prisões com base nas normas e conceitos educacionais, propõe-se estabelecer um breve retrato do sistema prisional brasileiro, com base nas reflexões propostas por Christie (1998); Wacquant (2002); Chantraine (2006) e Garland (2008), entre outros, sobre as políticas prisionais que vem se estendendo mundo afora.

\footnotetext{
${ }^{5}$ No mesmo sentido, ao defender a exigibilidade e a justiciabilidade de todos os direitos humanos, Cançado Trindade, durante palestra na IV Conferência Nacional de Direitos Humanos ${ }^{5}$, ponderou que "no futuro, os direitos econômicos, sociais e culturais básicos poderiam vir a compor um núcleo mais enriquecido de direitos fundamentais e inderrogáveis [..]. Tal núcleo seria constituído pelos direitos ao trabalho, à saúde e à educação" (CÂMARA FEDERAL, 2000, p.26).
} 


\subsection{Breve retrato da prisão}

A população carcerária brasileira era, em junho de 2009, de acordo com dados do Ministério da Justiça, de 469.546 pessoas. Dessas, 93,5\% são homens e 6,5\% mulheres, em sua maioria pessoas jovens - 56,9\% têm menos de 29 anos - , 56,1\% são negras e com baixo grau de escolaridade, sendo que o ensino fundamental não foi concluído por $65,7 \%$, conforme indicam dados das Tabelas 2, 3 e 4.

Tabela 2 - População carcerária nacional, por faixa etária

\begin{tabular}{|l|l|l|l|}
\hline Faixa etária & Masculina (\%) & Feminina (\%) & Total (\%) \\
\hline 18 a 24 anos & 31,3 & 27,7 & 31,1 \\
\hline 25 a 29 anos & 25,9 & 22,8 & 25,8 \\
\hline 30 a 34 anos & 16,9 & 18,2 & 16,9 \\
\hline 35 a 45 anos & 14,4 & 18,4 & 14,7 \\
\hline 46 a 60 anos & 5,4 & 7,6 & 5,6 \\
\hline Mais de 60 anos & 1,0 & 0,8 & 0,9 \\
\hline Não foi Informado & 2,3 & 0,8 & 2,2 \\
\hline Valor de correção* & 2,8 & 3,7 & 2,8 \\
\hline
\end{tabular}

Dados produzidos com base nas informações disponíveis em: < http://www.mj.gov.br $>$ (Infopen - jun/2009).

*Valor automático de correção de itens inconsistentes - Diferença com relação à população carcerária do Estado.

Tabela 3 - População carcerária nacional por cor da pele e etnia

\begin{tabular}{|l|l|l|l|}
\hline Cor da pele/etnia & Masculina (\%) & Feminina (\%) & Total (\%) \\
\hline Branca & 36,8 & 36,7 & 36,8 \\
\hline Preta & 16,5 & 16 & 16,5 \\
\hline Parda* & 39,6 & 39,9 & 39,6 \\
\hline Amarela & 0,6 & 0,4 & 0,6 \\
\hline Indígena & 0,1 & 0,1 & 0,1 \\
\hline Outras & 3,4 & 1,1 & 3,3 \\
\hline Valor de correção* & 2,9 & 5,8 & 3,1 \\
\hline Pessoas Negras & Homens & Mulheres & Total \\
\hline \% & $\mathbf{5 6 , 1}$ & $\mathbf{5 5 , 8}$ & $\mathbf{5 6 , 1}$ \\
\hline
\end{tabular}

Dados produzidos com base nas informações disponíveis em: < http://www.mj.gov.br> (Infopen - jun/2009).

*A denominação utilizada no relatório produzido pelo Depen era "Negra", porém conforme classificação do IBGE, a população negra consiste na somatória das pessoas pretas e pardas.

**Valor automático de correção de itens inconsistentes - Diferença com relação à população carcerária do Estado. 
Tabela 4 - População carcerária nacional, por grau de instrução

\begin{tabular}{|l|l|l|l|}
\hline Escolaridade & Masculina (\%) & Feminina (\%) & Total (\%) \\
\hline Analfabeta & 7,8 & 5,4 & 7,7 \\
\hline Alfabetizada & 12,3 & 13,2 & 12,3 \\
\hline Ensino Fundamental Incompleto & 45,9 & 45,5 & 45,7 \\
\hline Ensino Fundamental Completo & 11,8 & 11,4 & 11,8 \\
\hline Ensino Médio Incompleto & 9,9 & 11,2 & 10 \\
\hline Ensino Médio Completo & 6,6 & 10,1 & 6,8 \\
\hline Ensino Superior Incompleto & 0,6 & 1,5 & 0,7 \\
\hline Ensino Superior Completo & 0,4 & 0,9 & 0,4 \\
\hline Ensino acima Ensino Superior & 0,02 & 0,03 & 0,02 \\
\hline Não foi Informado & 3,9 & 1,3 & 3,8 \\
\hline Valor de correção* & 0,7 & 0,9 & 0,8 \\
\hline
\end{tabular}

Dados produzidos com base nas informações disponíveis em: < http://www.mj.gov.br> (Infopen - jun/2009).

*Valor automático de correção de itens inconsistentes - Diferença com relação à população carcerária do Estado.

A população carcerária do Estado de São Paulo, com 158.704 pessoas - 93,2\% são homens e $6,8 \%$, mulheres -, representa $33,8 \%$ do total nacional, e o perfil das pessoas encarceradas no Estado é similar ao descrito anteriormente. As pessoas com menos de 29 anos representam 55,4\% do universo; $48,6 \%$ são negras e 57,9\% não concluíram o ensino fundamental.

De acordo com dados da Fundação Seade, em 2004, a população negra paulista era de $28,7 \%$, enquanto na prisão ela representa $48,6 \%$ do total de pessoas presas. Em relação à escolaridade, $47 \%$ da população de São Paulo, com idade de 10 anos ou mais, têm menos de 8 anos de estudo, quando na prisão, $57,9 \%$ da população não concluiu o ensino fundamental. ${ }^{6}$

Tabela 5 - População carcerária paulista, por faixa etária

\begin{tabular}{|l|l|l|l|}
\hline Faixa etária & Masculina (\%) & Feminina (\%) & Total (\%) \\
\hline 18 a 24 anos & 31,2 & 21,3 & 30,6 \\
\hline 25 a 29 anos & 25,0 & 21,7 & 24,8 \\
\hline 30 a 34 anos & 16,4 & 20,2 & 16,8 \\
\hline 35 a 45 anos & 13,5 & 18,3 & 13,7 \\
\hline 46 a 60 anos & 5,1 & 6,3 & 5,2 \\
\hline Mais de 60 anos & 1,1 & 0,8 & 1,0 \\
\hline Não foi Informado & 0,1 & - & 0,1 \\
\hline Valor de correção* & 7,6 & 11,4 & 7,8 \\
\hline
\end{tabular}

Dados produzidos com base nas informações disponíveis em: < http://www.mj.gov.br> (Infopen - jun/2009).

*Valor automático de correção de itens inconsistentes - Diferença com relação à população carcerária do Estado.

\footnotetext{
${ }^{6}$ FUNDAÇÃO SEADE. Disponível em: <http://www.seade.gov.br/produtos/idr/menu_tema_4.php?opt $=\mathrm{s} \&$ tema $=$ edu\&subtema $=1>$. Acesso em: $10 \mathrm{fev} .2010$.
} 
Tabela 6 - População carcerária paulista, por cor da pele/etnia

\begin{tabular}{|l|l|l|l|}
\hline Cor da pele/etnia & Masculina (\%) & Feminina (\%) & Total (\%) \\
\hline Branca & 42,6 & 40,4 & 42,5 \\
\hline Preta & 15,7 & 12,7 & 15,5 \\
\hline Parda* & 33,2 & 31,3 & 33,1 \\
\hline Amarela & 0,1 & 0,2 & 0,2 \\
\hline Indígena & 0,01 & 0,02 & 0,01 \\
\hline Outras & 0,3 & - & 0,3 \\
\hline Valor de correçã** & 8,1 & 15,4 & 8,4 \\
\hline Pessoas Negras & Homens & Mulheres & Total \\
\hline \% & $\mathbf{4 8 , 9}$ & $\mathbf{4 4 , 0}$ & $\mathbf{4 8 , 6}$ \\
\hline
\end{tabular}

Dados produzidos com base nas informações disponíveis em: $<$ http://www.mj.gov.br $>$ (Infopen - jun/2009).

* A denominação utilizada no relatório produzido pelo Depen era "Negra", porém conforme classificação do IBGE, a população negra consiste na somatória das pessoas pretas e pardas.

**Valor automático de correção de itens inconsistentes - Diferença com relação à população carcerária do Estado.

Tabela 7 - População carcerária paulista, por grau de instrução

\begin{tabular}{|l|l|l|l|}
\hline Escolaridade & Masculina (\%) & Feminina (\%) & Total (\%) \\
\hline Analfabeta & 3,5 & 2,9 & 3,5 \\
\hline Alfabetizada & 14,6 & 14,8 & 14,6 \\
\hline Ensino Fundamental Incompleto & 40,0 & 36,4 & 39,8 \\
\hline Ensino Fundamental Completo & 15,5 & 12,8 & 15,3 \\
\hline Ensino Médio Incompleto & 11,6 & 13,1 & 11,7 \\
\hline Ensino Médio Completo & 8,7 & 13,9 & 8,9 \\
\hline Ensino Superior Incompleto & 0,7 & 1,8 & 0,7 \\
\hline Ensino Superior Completo & 0,4 & 1,4 & 0,5 \\
\hline Ensino acima Ensino Superior & 0,01 & 0,05 & 0,01 \\
\hline Não foi Informado & 3,0 & - & 2,9 \\
\hline Valor de correção* & 2,0 & 2,9 & 2,1 \\
\hline Dados profing
\end{tabular}

Dados produzidos com base nas informações disponíveis em: < http://www.mj.gov.br $>$ (Infopen - jun/2009).

*Valor automático de correção de itens inconsistentes - Diferença com relação à população carcerária do Estado.

Os dados confirmam o que vários autores (DI GIORGI, 2006; BAUMAN, 1999; GARLAND, 2008; CHRISTIE, 1998; WACQUANT, 2002) constataram ao analisar o perfil da população carcerária em diferentes países: o sistema é seletivo e o recrutamento da população carcerária entre as pessoas socioeconomicamente desfavorecidas e/ou de grupos étnicos-raciais marginalizados é uma das características comuns verificadas em diferentes países, ao lado da ampliação do encarceramento independentemente do aumento, estabilização ou diminuição das taxas de criminalidade, bem como o abandono da ideia de que a função da prisão é a recuperação dos indivíduos. 


\subsubsection{Seleção étnico-racial}

Em relação à seleção étnico-racial, Blumstein ${ }^{7}$ (1991 apud CHRISTIE, 1998, p. 127), informa que, no final da década de 1980 e início de 1990, os Estados Unidos tinham 25\% dos homens negros, na faixa dos 20 anos, "sob o controle da justiça criminal”.

Reafirmando recentemente esses dados, Di Giorgi (2006, p. 97) afirma que nos Estados Unidos o cárcere tende a se tornar cada vez mais "negro" e "pobre" e que este fenômeno também é observável nas prisões da Europa. “Os migrantes estão superrepresentados em todos os sistemas carcerários europeus. Na Itália, por exemplo, de 1990 até hoje o percentual de migrantes no total da população carcerária passou de $15 \%$ para $30 \%$."

No Brasil em geral, e no Estado de São Paulo em particular, também a prisão de migrantes é bastante seletiva, e pessoas originárias de países latino-americanos e africanos representam a maior parte dos estrangeiros encarcerados entre nós.

\section{Tabela 8 - Pessoas estrangeiras por Continente de origem na população carcerária do Brasil e S. Paulo}

\begin{tabular}{|l|l|l|l|l|l|l|}
\hline Grupo & Masculina (\%) & \multicolumn{2}{l|}{ Feminina (\%) } & Total (\%) \\
\hline & Brasil & São Paulo & Brasil & São Paulo & Brasil & São Paulo \\
\hline Europa & 18,2 & 19,0 & 18,4 & 19,0 & 18,3 & 19,0 \\
\hline Ásia & 4,6 & 5,6 & 7,3 & 10,2 & 5,3 & 6,8 \\
\hline África & 24,8 & 34,4 & 27,2 & 33,6 & 25,4 & 34,2 \\
\hline América & 52,3 & 40,8 & 47,0 & 36,9 & 50,9 & 39,8 \\
\hline Oceania & 0,1 & 0,2 & 0,1 & 0,2 & 0,1 & 0,2 \\
\hline
\end{tabular}

Dados produzidos com base nas informações disponíveis em: < http://www.mj.gov.br> (Infopen - jun/2009).

Bolívia, Paraguai e Peru são os países de origem da maior parte dos presos estrangeiros no Brasil, com respectivamente 500, 358 e 243 pessoas. Considerada a população carcerária de São Paulo, as proporções gerais se mantêm, mas nota-se maior presença de presos originários de países africanos, sendo que os três países de origem dos maiores números de presos são Bolívia, com 217; Peru, 168 e Nigéria, 155. Apenas para registro: há 11 norte-americanos presos no Brasil, sendo que três estão no sistema prisional paulista.

Em razão dessa seletividade, diversos autores consideram que as formas de gestão da criminalidade coincidem com a gestão da pobreza ou com o controle dos grupos sociais considerados perigosos, porque excluídos das possibilidades de inserção na organização das

\footnotetext{
${ }^{7}$ BLUMSTEIN, Alfred. Demographic factors: now in the future. In: Grouth and its influence on correctional policy. Guggenheim Criminal Justice Program, Berkeley, USA, 1991.
} 
sociedades, sobretudo no que se refere ao mercado de trabalho, conforme explica Di Giorgi (2006, p. 90):

\begin{abstract}
Quando falo de exclusão social, de desemprego, de marginalidade, referindo esses termos a aspectos de um excesso negativo, procuro evidenciar dois pólos de uma contradição que parece insolúvel nas condições atuais. De um lado, observamos uma sociedade cujas dinâmicas de inclusão social são mediadas pelo trabalho entendido como emprego, como ocupação a templo pleno, garantida, continuada e estável, em resumo, uma sociedade que continua a subordinar a titularidade dos direitos de cidadania e, em última instância, do direito à existência à condição de ser trabalhador ou trabalhadora. De outro lado, porém, emerge uma estrutura das relações de produção que se funda exatamente na redução e precarização do trabalho.
\end{abstract}

Dessa forma, são as pessoas que não conseguem acessar sequer os precários postos de trabalho que constituem o público prioritário das prisões, conforme demonstrado a seguir.

\title{
1.1.2 Ampliação do encarceramento
}

A outra característica comum a diversos países, notadamente a partir da década de 1990, é o intenso aumento da população carcerária, independentemente das taxas de criminalidade, como explica Wacquant (2002, p. 21), ao demonstrar que durante 1975 e 1995, quando a população carcerária norte-americana quadruplicou, os roubos qualificados e o índice de vítimas por lesões corporais mantiveram taxas estáveis e o número de crimes contra os bens diminuiu:

O fato de a população carcerária ter quadruplicado em duas décadas não se explica pelo aumento da criminalidade violenta, mas sim pela extensão do recurso ao aprisionamento para uma gama de crimes e delitos que até então não levavam à pena de prisão, a começar por infrações menores na legislação dos entorpecentes e pelos atentados à ordem pública.

Outros atores também concordam que a ampliação do encarceramento está relacionada à mudança dos critérios do controle, que teve início nos Estados Unidos, com a chamada política de "tolerância zero" e a "guerra" contra o tráfico de entorpecentes, iniciada no governo de Ronald Reagan (1981-1988), que encontrou eco na gestão da primeira-ministra Margaret Tatcher (1979-1990), no Reino Unido (GARLAND, 2008), e se disseminou por diversos países, assumindo diferentes contornos em função das realidades nacionais. 
Singer (2003, p. 318) sintetiza o conjunto de políticas que levaram à ampliação do encarceramento nos EUA e se disseminou por outros países:

[...] Este crescimento incessante dos encarceramentos deve-se, em primeiro lugar, à política de repressão aos pequenos delitos. Esta política ganhou força depois que foi adotada, em 1994, pelo prefeito de Nova York, Rudolph Giuliani, recebendo a alcunha de política de "tolerância zero" ou "qualidade de vida". Trata-se de um conjunto de reformas e estratégias do Departamento de Polícia da cidade, que tem por base teórica "a teoria das janelas quebradas", publicada por James Q.. Wilson e Georges Keling, em 1982 [...]. Segundo esta teoria, uma pequena infração, se tolerada, pode levar a um clima de anomia que gerará as condições propícias para que ocorram delitos mais graves. (SINGER, 2003, p. 318).

Christie (1998, p. 38) demonstra que mesmo países que tinham uma tradição de bastante tolerância aos entorpecentes passaram a sofrer pressão da comunidade internacional para adotar regras restritivas. "A Holanda sofreu, sem dúvida, extraordinárias pressões internacionais que exigem uma política em relação às drogas, mais severa; a Alemanha e a Suécia, em particular, há muito afirmam que a Holanda é o elo fraco da defesa europeia contra as drogas."

No Brasil, é possível identificar tanto a ampliação do encarceramento como a relevância dos "entorpecentes" entre as causas do encarceramento. O crescimento da população carcerária nacional pode ser verificado no Gráfico 1.

$\mathrm{Na}$ apresentação da edição brasileira de "A cultura do controle" (GARLAND, 2008), André Nascimento assinalava que a taxa de crescimento do número de encarcerados era de aproximadamente $10 \%$ ao ano e alertava para o risco de o Brasil atingir "a sinistra marca dos 500 mil presos" até a metade de 2009: até junho do referido ano, eram 469.546 pessoas presas. 


\section{Gráfico 1 - População Carcerária Brasileira}

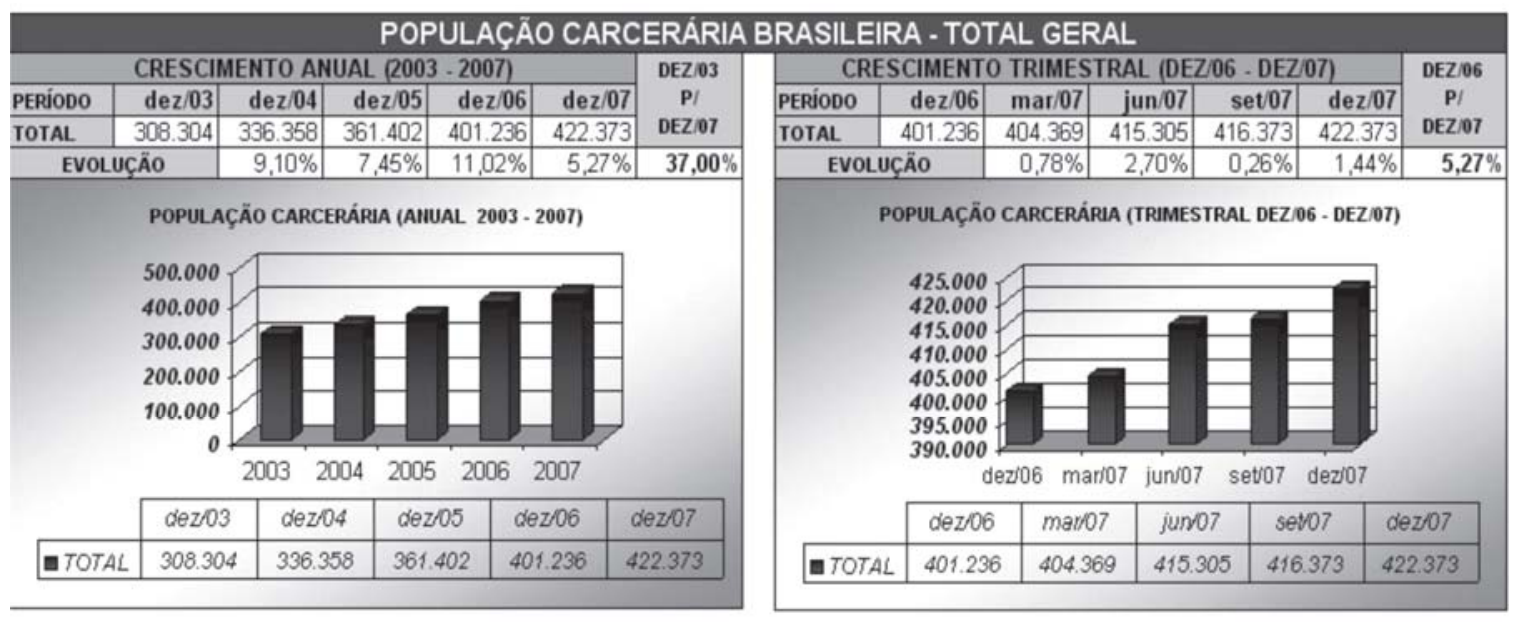

Fonte: Departamento Penitenciário Nacional (Depen/MJ). Sistema Nacional de Informação Penitenciária (Infopen). Dados consolidados em 2007. Disponível em: <www.mj.gov.br>. Acesso em: 10/fev/2010.

\section{Gráfico 2 - População carcerária - Estado de São Paulo}

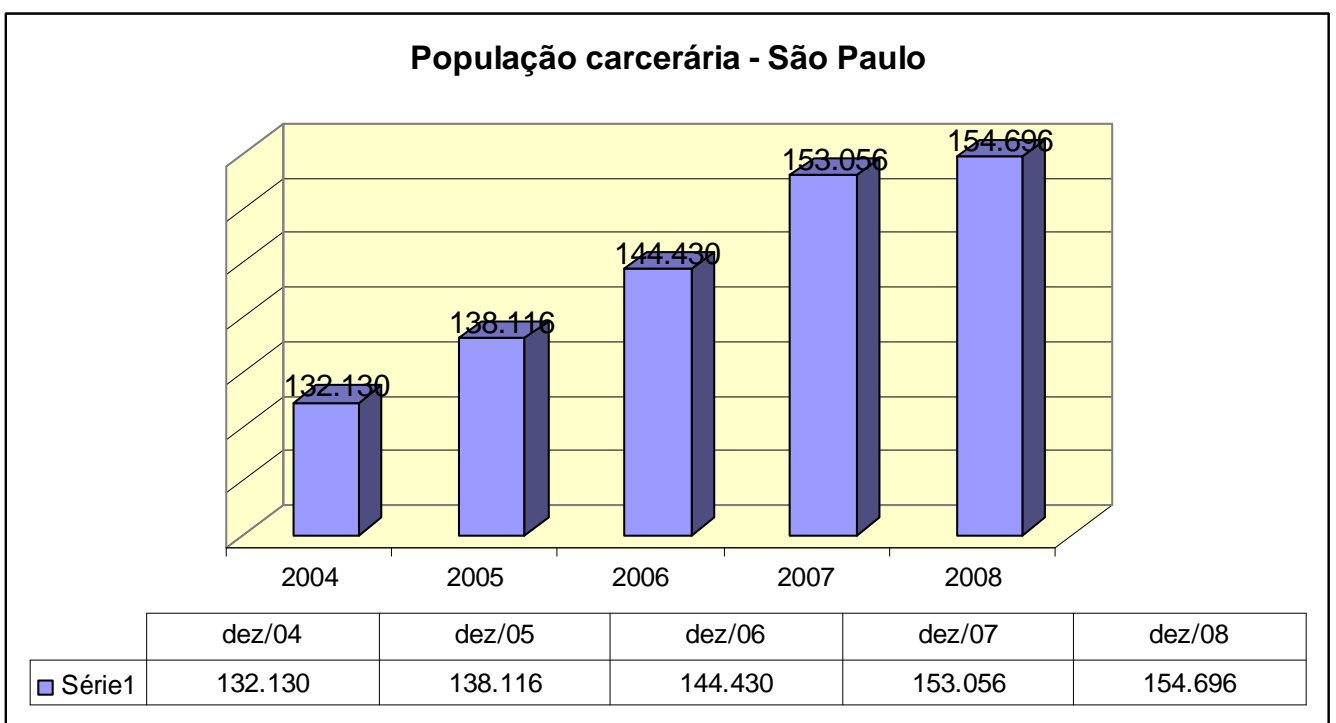

Fonte: Departamento Penitenciário Nacional (Depen/MJ). Sistema Nacional de Informação Penitenciária (Infopen). Dados consolidados 2005 e 2007. Disponível em: <www.mj.gov.br>. Acesso em: 10 fev. 2010.

No entanto, tanto os dados nacionais quanto aqueles referentes ao crescimento da população carcerária do Estado de São Paulo demonstram que o ritmo da ampliação é bem inferior àquele verificado nos Estados Unidos.

Nascimento (2008, p. 10) afirma que as práticas político-criminais dos EUA continuarão a ser repetidas no Brasil, mas nunca serão equiparáveis por três razões: 1) tradições jurídicas diferentes, havendo menor "flexibilidade na criação do direito"; 2) 
orçamentos públicos "mais modestos"; 3) diante dos déficits sociais, os políticos se inibem em propor legislações que desloquem recursos para o aparato da segurança.

No mesmo sentido, Gomes (1998, XVII) também acredita que o Brasil não repetirá a escalada norte-americana na ampliação do encarceramento por falta de acesso a recursos tecnológicos. O autor, concordando com Christie (1998), ressalta que a adoção de modelos de controle social não são apenas resultado da racionalidade econômica ou tecnológica, mas determinada também por questões culturais. Nesse sentido, sendo otimista, afirma que o debate sobre as penas alternativas, intensificado a partir da segunda metade da década de 1990, aponta em direção oposta ao encarceramento em massa.

Por fim, outro fator que impede, pelo menos até o momento, a ampliação do ritmo do encarceramento é a inimputabilidade penal dos adolescentes. Não por acaso, a cada crime que ganha destaque na imprensa envolvendo adolescentes, o tema da redução da idade penal ganha a cena pública por meio de discursos inflamados, que bradam a favor da necessidade de endurecimento: das leis, das condutas, das penas.

Em relação às causas do encarceramento, também aqui no Brasil a desobediência à legislação sobre entorpecentes está entre as principais razões de encarceramento. Considerado o total da população, os crimes contra o patrimônio foram a causa da prisão de 210.501 pessoas; 85.506 foram condenadas com base na legislação sobre entorpecentes; 50.834 cometeram crimes contra a pessoa e 17.928, contra os costumes. Considerada a população prisional feminina, os entorpecentes são a primeira causa de encarceramento (11.629), seguida dos crimes contra o patrimônio (5.438) e, por fim, contra a pessoa (1.504). A população masculina segue a proporção nacional, em ordem decrescente do número de condenações: crimes contra o patrimônio (205.063); entorpecentes (73.877) e crimes contra a pessoa $(49.330)^{8}$.

As pessoas que cumprem pena em razão de crimes contra o patrimônio e entorpecentes representam $63 \%$ do total da população carcerária, enquanto aquelas vinculadas aos crimes contra a pessoa são $10,9 \%$.

Nascimento (2008, p. 20) classifica os crimes contra o patrimônio e tráfico de drogas ilícitas como sendo "relacionados ao acesso forçado à renda" e adverte:

Estes dados só revelam uma realidade que é por demais óbvia, mas que o senso comum criminológico tenta escamotear: o sistema penal criminaliza a pobreza e,

\footnotetext{
${ }^{8}$ BRASIL. Ministério da Justiça. Dados referentes a junho de 2009. Disponível em: <http://www.mj.gov.br>. Acesso em: 10 fev. 2010.
} 
como o neoliberalismo multiplica a pobreza, o número de criminalizados cresce e crescerá na mesma proporção. (NASCIMENTO, 2008, p. 20).

A origem histórica da distribuição das penas, orientada por critérios de pertencimento a grupos sociais, foi explicada por Foucault, em Vigiar e Punir, ao registrar que na segunda metade do século XVIII, concomitantemente à constituição dos centros urbanos, novas formas de acumulação do capital e sua regulação formal, as ilegalidades passaram a ser geridas por uma nova economia.

[...] de um lado, a ilegalidade mais acessível às classes populares será a dos bens transferência violenta das propriedades; de outro a burguesia, então, se reservará a ilegalidade dos direitos: a possibilidade de desviar seus próprio regulamentos e suas próprias leis [...] E essa grande redistribuição das ilegalidades se traduzirá atéo por uma especialização dos circuitos judiciários: para as ilegalidades de bens - para o roubo -, os tribunais ordinários, os castigos; para as ilegalidades de direitos fraudes, evasões fiscais, operações comerciais irregulares - jurisdições especiais com transações, acomodações, multas atenuadas, etc. (FOUCAULT, 1987, p. 80).

Transpondo esta perspectiva de análise para a atualidade, Schilling (2007, p. 19), aponta problemas na relação crime/pena "que se tornam radicalmente visíveis":

\begin{abstract}
Se o crime mais punido com a prisão continua sendo o roubo, pesquisas junto às comunidades de territórios urbanos "violentos" colocam como o pior crime os crimes contra a vida (homicídio) e o estupro. Vida ou propriedade? A constatação desta distribuição desigual de justiça no Brasil encontra-se verificada por inúmeras pesquisas: os crimes da pobreza (transferência violenta de propriedade) ou os crimes contra o patrimônio particular são mais punidos que os crimes contra o patrimônio público. No campo de atuação da lei na punição dos crimes fatais há, também, diferenças: a lei é indiferente quando os crimes acontecem envolvendo agressores pobres contra vítimas pobres, principais alvos da delinquência, como assinalava Foucault. É, portanto, indiferente, quando envolve pobres contra pobres; severa, quando os crimes fatais acontecem na direção dos pobres contra ricos; é complacente, quando se trata de homens contra mulheres; cheia de hesitações, quando se trata de crimes fatais de ricos contra ricos. (SHILLING, 2007, p. 19).
\end{abstract}

A ideia de que a prisão é, na atualidade, um mecanismo de controle, uma forma de tirar de circulação pessoas pobres, é consequência de "sinais de mudança" (GARLAND, 2008) que se manifestam nas estruturas de controle do crime em diferentes países.

A consequência mais imediata da ampliação do encarceramento é a superlotação das unidades. De acordo com Shecaira (2010), entre os países da América Latina, o Brasil é o que tem o maior déficit de vagas, o que significa a pior condição em termos de superpopulação, com unidades que chegam a ter mais de três vezes o número de presos previstos. Falta espaço para colocar tantas pessoas, mas também faltam recursos para contratar funcionários para manter a ordem e organizar a vida nas prisões. Então, a solução gerencial encontrada é que os 
presos sejam tomados como parceiros na tarefa de manter o bom funcionamento dos estabelecimentos, partilhando as responsabilidades com os funcionários, sendo este um dos elementos da "prisão pós-disciplinar" (CHANTRAINE, 2006).

A consequência subsequente, dada a limitada capacidade orçamentária do Estado em construir mais prisões, é a privatização do sistema prisional, um mercado bastante lucrativo que vem se desenvolvendo intensamente nos Estados Unidos (WACQUANT, 2002; Christie, 1998).

\subsubsection{Fim do ideal de reabilitação}

Aceitar que a prisão destina-se a imobilizar, tirar de circulação indivíduos, significa que esta instituição perdeu a razão de sua própria criação, no século XIX, de disciplinar pessoas (FOUCAULT, 1987). Daí, que alguns autores consideram que a partir da década de 1970 vem se consolidando a "prisão pós-disciplinar" (CHANTRAINE, 2006), constituída graças à “ascensão do Estado penal” (WACQUANT, 2002).

Garland (2008) relaciona "os sinais de mudança" verificados nas prisões norteamericanas e do Reino Unido ao fim do Estado do Bem-Estar Social ou advento do "neoliberalismo". De maneira geral, trata-se da retirada, ou drástica redução, das garantias sociais acessadas pela população pobre daqueles países, incluindo as pessoas presas, colocando fim ao que o autor denominou "previdenciarismo penal" e aos ideais que o formataram, baseados na crença de que a reabilitação social dependia do acesso a direitos: saúde, educação, trabalho, assistência social.

No novo período, os presos não são mais considerados pessoas dignas de solidariedade, mas, sim, indivíduos perigosos, merecedores de punições exemplares, capazes de amedrontar possíveis novos infratores e vingar a vítima e a sociedade dos males praticados.

Chantraine (2006) explica esse cenário não como uma negação dos direitos das pessoas presas, afinal, ele se conforma simultaneamente à formalização dessas conquistas. $\mathrm{O}$ autor identifica uma "adaptação" do sistema prisional, que se opera em seu cotidiano, e envolve tanto dirigentes quanto funcionários das instituições e, acima de tudo, a própria população carcerária.

As reflexões dos dois autores, entre outros, contribuirão para a compreensão das informações e dados levantados no campo pesquisado. Nesta introdução, duas ideias iluminam o retrato da prisão no Brasil: o contexto é absolutamente desfavorável às atividades 
voltadas à garantia das "assistências" ao preso, ainda que estejam determinadas na Lei de Execução Penal (LEP, 1984); a organização do sistema prisional está baseada nas relações forjadas entre representantes do Estado e organizações de presos, e seu equilíbrio baseia-se nos riscos que correm as duas partes.

Não é possível afirmar, no entanto, que as reflexões desses autores, elaboradas com base em realidades muito distintas das nossas, possam ser transpostas em sua totalidade para auxiliar na compreensão nacional. Mas há alguns sinais que, sem dúvida, contribuem para a compreensão de que a gestão e a organização do sistema prisional brasileiro seguem algumas tendências verificadas em outros países.

Por exemplo, a ideia de uma prisão pós-disciplinar parece estranha, pois há dúvidas que o Brasil tenha concretizado a prisão disciplinar, tal qual descrita por Focault (1987), sobretudo porque, como demonstrado ao longo deste trabalho e em outros estudos, o Estado nunca assumiu de fato a responsabilidade pelas pessoas presas.

As prisões brasileiras sempre se aproximaram muito mais da ideia de depósito de seres humanos do que de instituições reformadoras de pessoas. Isso chegou a tal ponto que sequer há informações sistematizadas sobre as ações do Estado no campo das "assistências", de forma a permitir analisar se essas práticas se reduziram ou ampliaram ao longo do tempo. Da mesma forma, assim como o Brasil nunca viveu nada parecido ao Estado de Bem-Estar Social, a não ser do ponto de vista da garantia formal dos Direitos, também o sistema prisional nunca experienciou o "previdenciarismo penal".

No entanto, é inegável que, a partir do final da década de 1990, a presença de grupos organizados de presos - denominadas facções criminosas - vem alterando a configuração do funcionamento das prisões brasileiras, de tal modo que, em 2006, em São Paulo, manifestou seu potencial de intervenção inclusive fora da prisão (ADORNO E SALLA, 2007). Ainda que as autoridades neguem, informações do campo pesquisado relatadas ao longo deste trabalho demonstram que esta nova configuração, e seus sistemas de privilégios, condicionam inclusive a atuação de organizações da sociedade civil no ambiente prisional, aproximando a realidade verificada da ideia de prisão pós-disciplinar, à moda brasileira.

Por fim, ainda que as prisões brasileiras não tenham experimentado nada parecido ao "previdenciarismo penal" - ao longo deste trabalho esta advertência aparecerá todas as vezes que as reflexões de Garland (2008) forem aludidas -, o sistema prisional paulista foi objeto de ações de humanização (TEIXEIRA, 2006), em diferentes períodos entre o final do século passado e os primeiros anos do novo milênio. Mas, nos últimos anos, verificou-se retrocesso, no sentido de buscar o endurecimento das relações e das penas, ao lado da ampliação do 
encarceramento, características que aproximam o contexto nacional em geral, e o paulista, em particular, da ideia de Estado penal - também à moda brasileira.

\subsubsection{Assistências e trabalho na prisão brasileira}

Para finalizar esta breve caracterização do sistema prisional brasileiro, em geral, e paulista, em particular; e já introduzindo as primeiras reflexões sobre o objeto desta pesquisa, serão verificados alguns dados sobre o acesso às atividades educacionais e laborais.

A Lei de Execução Penal determina, em seu artigo 10, que a assistência ao preso e ao internado é dever do Estado, objetivando prevenir o crime e orientar o retorno à convivência em sociedade; e, no artigo 11 determina que a assistência será material, incluindo os campos da saúde, assistência jurídica, formação educacional, social e religiosa.

A LEP (1984) dedica ainda um capítulo específico sobre o trabalho dos presos e, no artigo 28, enuncia o objetivo das atividades laborais: "O trabalho do condenado, como dever social e condição de dignidade humana, terá finalidade educativa e produtiva”. Entre os artigos 28 a 37, a Lei dedica-se a regular a remuneração e as condições de trabalho desenvolvido interna e externamente à prisão, em função do regime de pena cumprido, além de estabelecer a remição penal na proporção de três dias trabalhados para um subtraído do total da pena.

Nota-se na LEP a centralidade do trabalho na missão de ressocializar ou reeducar os indivíduos, tanto assim que a formulação lhe confere caráter educativo, independentemente do tipo de atividade, tal qual supõe Foucault (1987, p. 216): “O trabalho penal deve ser concebido como sendo por si mesmo uma maquinária que transforma o prisioneiro violento, agitado, irrefletido em uma peça que desempenha seu papel com perfeita regularidade".

Apesar da enunciada centralidade na organização da vida prisional, em junho de 2009, apenas $17,7 \%$ das pessoas presas cumprindo penas no regime aberto ou semiaberto participavam de programas de laborterapia ou atividades de trabalho externo. Dessas, 48,6\% eram vinculadas a iniciativa privada e $18,4 \%$, a órgãos estatais, sendo quase insignificantes $(1,6 \%)$ as oportunidades de trabalho relacionadas às ONGs em geral e ao "Sistema S", em particular, conforme Tabelas 8 e 9 . 
Tabela 9 - Pessoas em programas de laborterapia - trabalho externo

\begin{tabular}{|l|l|l|l|}
\hline & $\begin{array}{l}\text { População } \\
\text { Regime Aberto + Semiaberto }\end{array}$ & $\begin{array}{l}\text { Pessoas trabalhando } \\
\text { Atividades Externas }\end{array}$ & $\%$ \\
\hline Homens & 78.331 & 13.883 & 17,7 \\
\hline Mulheres & 5.258 & 891 & 16,9 \\
\hline Total & 83.589 & 14.774 & 17,7 \\
\hline
\end{tabular}

Dados produzidos com base nas informações disponíveis em: < http://www.mj.gov.br> (Infopen - jun/2009).

Tabela 10 - Trabalho externo - de acordo com tipo de atividade

\begin{tabular}{|l|l|l|l|}
\hline Tipo atividade & Masculina (\%) & Feminina (\%) & Total (\%) \\
\hline Parceria com iniciativa privada & 49,1 & 39,4 & 48,6 \\
\hline Parceria com órgãos do Estado & 17,8 & 26,9 & 18,4 \\
\hline Parceria com Paraestatais (Sistema S e ONG) & 1,6 & 2,5 & 1,6 \\
\hline Atividade Desenvolvida - Artesanato & 17,7 & 27,2 & 18,2 \\
\hline Atividade Desenvolvida - Rural & 4,2 & 1,2 & 4,0 \\
\hline Atividade Desenvolvida - Industrial & 9,6 & 2,8 & 9,2 \\
\hline
\end{tabular}

Dados produzidos com base nas informações disponíveis em: < http://www.mj.gov.br> (Infopen - jun/2009).

As pessoas presas provisórias, sentenciadas em regime fechado, e aquelas internadas em Medida de Segurança teriam o dever e o direito de trabalhar e de desenvolver trabalhos internos às unidades. Desse grupo, apenas 19,3\% participam de algum programa de laborterapia e, nota-se, que a maioria, 42,2\%, atua em atividades de apoio ao estabelecimento penal, que significa efetuar grande parte das atividades, da limpeza ao trabalho administrativo, conforme relatado em diferentes estudos e ao longo dessa pesquisa (Tabelas 11 e 12).

Tabela 11 - Pessoas em programas de laborterapia - trabalho interno

\begin{tabular}{|l|l|l|l|}
\hline & $\begin{array}{l}\text { População carcerária, exceto Regime } \\
\text { Aberto e Semiaberto }\end{array}$ & $\begin{array}{l}\mathrm{N}^{\mathrm{o}} \text { pessoas trabalhando } \\
\text { Atividades Internas }\end{array}$ & $\%$ \\
\hline Homens & 360.696 & 67.886 & 18,8 \\
\hline Mulheres & 25.261 & 6.610 & 26,2 \\
\hline Total & 385.957 & 74.496 & 19,3 \\
\hline
\end{tabular}

Dados produzidos com base nas informações disponíveis em: < http://www.mj.gov.br> (Infopen - jun/2009).

Tabela 12 - Trabalho interno - de acordo com tipo de atividade

\begin{tabular}{|l|l|l|l|}
\hline Tipo atividade & Masculina (\%) & Feminina (\%) & Total (\%) \\
\hline Apoio ao Estabelecimento Penal & 42,6 & 41,7 & 42,6 \\
\hline Parceria com a Iniciativa Privada & 26,1 & 29,6 & 26,4 \\
\hline Parceria com Órgãos do Estado & 3,4 & 8,6 & 3,8 \\
\hline Parceria com Paraestatais (Sistema S e ONG) & 0,3 & 0,8 & 0,4 \\
\hline Atividade Desenvolvida - Artesanato & 19,3 & 17,7 & 19,2 \\
\hline Atividade Desenvolvida - Rural & 3,4 & 0,8 & 3,1 \\
\hline Atividade Desenvolvida - Industrial & 4,9 & 0,8 & 4,5 \\
\hline
\end{tabular}


No sistema prisional paulista, os dados indicam maior participação da população carcerária em atividades laborais, sendo que $24,9 \%$ participam de atividades externas e $26,6 \%$ internas 9 .

A respeito dos limites das atividades laborais como elemento organizador da prisão, Bauman (1999), afirma que, na pós-modernidade, a ética do trabalho não pode mais ser aplicada à organização da prisão, ainda que os discursos oficiais continuem a afirmá-la como meio de ressocialização ou reintegração, ou outro termo qualquer que remeta à ideia de oferecer condições para que a pessoa retorne ao convívio social, com possibilidade de manterse autonomamente, dentro das regras sociais.

O trabalho não pode mais ser o eixo organizador da prisão porque não há trabalho para todas as pessoas, principalmente para aquelas que não têm como acessar as ocupações geradas pelas novas tecnologias e não fazem parte de redes sociais.

Quais seriam, de fato, as possibilidades de trabalho para jovens pobres, sem instrução formal, numa sociedade em que não há emprego e a concentração de renda impede alternativas de organização social e distribuição de bens materiais e culturais? A esta pergunta, torna-se elucidativa a afirmação de Bauman (1999, p. 119-120):

Nas atuais circunstâncias, o confinamento é antes uma alternativa ao emprego, uma maneira de utilizar ou neutralizar uma parcela considerável da população que não é necessária à produção e para a qual não há trabalho "ao qual se reintegrar". (BAUMAN, 1999, p. 119-120).

Mas as restrições do mercado de trabalho não justificam inteiramente a reduzida participação da população carcerária em atividades laborais. Também as atividades de educação, sobre as quais não incidem restrições de natureza econômica para o acesso, são usufruídas (por)/disponibilizadas (a) um reduzido número de pessoas presas.

Assim, em âmbito nacional, apenas $8,4 \%$ da população carcerária frequenta atividades da educação formal, e não há informações sobre a frequência às iniciativas de educação não formal, foco desta pesquisa.

A maneira como as informações sobre educação está disposta não permite a identificação das diferentes práticas desenvolvidas para a elevação da escolaridade da população carcerária. Estudos (SENA, 2004; GRACIANO, 2005, CARREIRA, 2009) indicam que há diferentes arranjos institucionais possíveis para esta oferta, incluindo parcerias das direções de unidades com os sistemas municipais públicos de ensino, transferência da

\footnotetext{
${ }^{9}$ Ver Anexo 3.
} 
responsabilidade para fundações vinculadas às secretarias responsáveis pela administração penitenciária, tentativa de organização de sistema específico de ensino, baseado na atuação das pessoas presas na função de educador/a e parcerias com igrejas ou ONGs, sobretudo na alfabetização.

A precariedade das condições da educação ofertada pode ser mensurada pela quantidade de profissionais do campo que atuam no sistema prisional brasileiro. Em junho de 2009, de acordo com dados do Ministério da Justiça, eram 111 pedagogos e 329 professores, para um total de 75.873 servidores penitenciários, funcionários públicos na ativa. Proporcionalmente, os profissionais de Pedagogia correspondem a $0,1 \%$ dos servidores penitenciários, e os professores a $0,4 \%$.

Não há informação sobre o número de educadores vinculados às secretarias de Educação e atuando no sistema prisional, o que impossibilita ter conhecimento da totalidade de profissionais da Educação que, independentemente do vínculo institucional empregatício, atuam nas prisões brasileiras.

Tabela 13 - Presos/internados em relação às atividades educacionais

\begin{tabular}{|l|l|l|l|}
\hline & População presa/internada & $\begin{array}{l}\mathrm{N}^{\mathrm{o}} \text { pessoas em } \\
\text { atividades educacionais }\end{array}$ & $\%$ \\
\hline Homens & 439.027 & 35.333 & 8 \\
\hline Mulheres & 30.519 & 4.320 & 14,2 \\
\hline Total & 469.546 & 39.653 & 8,4 \\
\hline
\end{tabular}

Dados produzidos com base nas informações disponíveis em: < http://www.mj.gov.br> (Infopen - jun/2009).

Tabela 14 - Pessoas estudando por etapa, modalidade ou nível de ensino

\begin{tabular}{|l|l|l|l|}
\hline Etapa/Modalidade/Nível cursado & Masculina (\%) & Feminina (\%) & Total (\%) \\
\hline Alfabetização & 26,2 & 27,2 & 26,3 \\
\hline Ensino Fundamental & 55,8 & 49,3 & 55,0 \\
\hline Ensino Médio & 15,7 & 16,1 & 15,8 \\
\hline Ensino Superior & 0,2 & 0,3 & 0,3 \\
\hline Curso Técnico & 2,1 & 7,1 & 2,6 \\
\hline
\end{tabular}

Dados produzidos com base nas informações disponíveis em: < http://www.mj.gov.br> (Infopen - jun/2009).

O índice de pessoas estudando no sistema prisional paulista é ligeiramente superior, 10,4\%, (Tabelas 14 e 15), mas como já demonstrado em outros estudos (GRACIANO, 2005; CARREIRA, 2009), parte dessa oferta não está vinculada ao sistema público de ensino, reduzindo-se à preparação dos educandos para a participação em exames de certificação, conduzida pelas próprias pessoas presas, sem apoio de material didático ou outras condições de ensino e aprendizagem. 
De acordo com dados do Ministério da Justiça, de junho de 2009, não constam professores ou pedagogos entre os servidores penitenciários paulistas. Também não há informação sobre o número de educadores vinculados às secretarias de Educação atuando nas prisões de São Paulo, assim como não há registro sobre as atividades de educação não formal empreendidas. Ainda assim, as informações oficiais afirmam que 16.457 pessoas estudam neste sistema!

Tabela 15 - Presos/internados em relação às atividades educacionais

\begin{tabular}{|c|c|c|c|}
\hline & População presa/internada & $\begin{array}{l}\mathrm{N}^{\circ} \text { pessoas em } \\
\text { atividades educacionais }\end{array}$ & $\%$ \\
\hline Homens & 147.885 & 15.168 & 10,3 \\
\hline Mulheres & 10.819 & 1.289 & 11,9 \\
\hline Total & 158.704 & 16.457 & 10,4 \\
\hline
\end{tabular}

Dados produzidos com base nas informações disponíveis em: < http://www.mj.gov.br> (Infopen - jun/2009).

Tabela 16 - Pessoas estudando por etapa, modalidade ou nível de ensino

\begin{tabular}{|l|l|l|l|}
\hline Etapa/Modalidade/Nível cursado & Masculina (\%) & Feminina (\%) & Total (\%) \\
\hline Alfabetização & 30,8 & 24,1 & 30,2 \\
\hline Ensino Fundamental & 45,7 & 43,1 & 45,6 \\
\hline Ensino Médio & 21,1 & 26,4 & 21,5 \\
\hline Ensino Superior & 0,1 & 0,3 & 0,1 \\
\hline Curso Técnico & 2,3 & 6,1 & 2,6 \\
\hline
\end{tabular}

Dados produzidos com base nas informações disponíveis em: < http://www.mj.gov.br> (Infopen - jun/2009).

Confundida com o trabalho. Exercido por pessoas não habilitadas. Protagonizada por entidades filantrópicas, ONGs, universidades, igrejas... afinal, o que é educação nas prisões? Esta é a resposta a ser respondida a seguir, por meio das indicações contidas nas normas que regulam a prisão, e das reflexões, distinções e aproximações entre as perspectivas formais, não formais e informais da educação. 


\subsection{A educação nas prisões, segundo as normas}

\subsubsection{O plano internacional}

A educação, como outros direitos econômicos, sociais e culturais, foi assegurada na Declaração Universal dos Direitos Humanos (1948) e, mais especificamente, no Pacto Internacional sobre Direitos Econômicos, Sociais e Culturais (Pidesc), de $1966^{10}$.

Na Declaração de 1948, a educação está assegurada no Artigo 26, assim formulado:

1. Todo homem tem direito à educação. A educação deve ser gratuita, pelo menos nos graus elementares e fundamentais. A instrução elementar será obrigatória. A instrução técnico-profissional será generalizada; o acesso aos estudos superiores será igual para todos, em função dos méritos respectivos.

2. A instrução será orientada no sentido do pleno desenvolvimento da personalidade humana e do fortalecimento do respeito pelos direitos do homem e pelas liberdades fundamentais. A instrução promoverá a compreensão, a tolerância e a amizade entre todas as nações e grupos nacionais ou religiosos, e coadjuvará as atividades das Nações Unidas em prol da manutenção da paz.

3. Os pais têm prioridade de direito na escolha do gênero de instrução que será ministrada a seus filhos.

Claude (2005) relata o debate empreendido entre representantes de diversos países quando da formulação do artigo $\mathrm{XXVI}^{11}$, no que se refere à definição dos objetivos da educação a ser universalizada. Ao fazê-lo, o documento reafirma a impossibilidade da neutralidade da educação (FREIRE, 1996, p.111) e assume que seu conteúdo deve ser formulado para atingir três objetivos específicos: pleno desenvolvimento da personalidade humana e fortalecimento do respeito aos direitos do ser humano e às liberdades fundamentais; promoção da compreensão, da tolerância e da amizade entre todas as nações e a todos os grupos raciais e religiosos; e incentivo às atividades da Organização das Nações Unidas (ONU) para a manutenção da paz (CLAUDE, 2005. p. 39).

\footnotetext{
${ }^{10}$ Em relação ao Pidesc, Comparato (2003, p. 276) chama a atenção sobre a conjuntura em que ocorreu sua elaboração, sobretudo a inviabilidade política, imposta pela Guerra Fria, de serem garantidos, num único tratado, tanto os DESCs quanto os direitos civis e políticos, previstos no Pacto sobre Direitos Civis e Políticos, também de 1966. Ambas as normas foram criadas para atender o Conselho Econômico e Social das Nações Unidas, que em 1946, determinou a criação da Comissão de Direitos Humanos, que tinha, entre suas atribuições, a elaboração da Declaração Universal dos Direitos Humanos, finalizada em 1948, e, a seguir, a constituição de um documento que conferisse força jurídica ao primeiro, como "um tratado ou uma convenção internacional" (2003, p.276). O Brasil ratificou os dois pactos em dezembro de 1991, por meio do Decreto Legislativo $\mathrm{n}^{\circ}$ 226, o que significa que o País comprometeu-se internacionalmente em cumprir suas determinações. A própria Constituição Federal, em seu artigo $5^{\circ}$, parágrafo $2^{\circ}$, afirma que os direitos e garantias nela expressos "não excluem outros decorrentes do regime e princípios por ela adotados, ou dos tratados internacionais em que a República Federativa do Brasil seja parte".

${ }^{11}$ E/CN. 4/SR.67, Comissão sobre os Direitos Humanos, Terceira Sessão. Relatório sumário da 69a Assembleia (Lake Success), 11 jun. 1948, p.13 apud CLAUDE, 2005, p. 39.
} 
Ao interpretar o artigo, considerando o significado das palavras e a justaposição das frases, o autor aponta para duas considerações importantes para a análise das atividades educativas identificadas no ambiente prisional. A primeira, refere-se à articulação entre a proposição de pleno desenvolvimento da personalidade humana e a responsabilidade por sua efetivação. "Dado o objetivo de pleno desenvolvimento da personalidade humana no contexto da sociedade - o único contexto em que ele pode ocorrer -, conclui-se que o direito à educação é um direito social, um bem social e uma responsabilidade da sociedade como um todo" (CLAUDE, 2005, p. 40).

A segunda consideração vincula o direito à educação para o exercício dos direitos humanos. "A lógica das duas ideias combinadas nos diz que, ao promover o pleno desenvolvimento da personalidade humana, e a dignidade que isso acarreta, a educação também promove os direitos humanos" (2005, p.41). Claude afirma, ainda, que a proposição estabelecida na Declaração antecipava as reflexões de Paulo Freire sobre "as conexões entre a educação do povo e a autorrealização, em consequência do aprendizado e do exercício dos direitos humanos" (2005, p. 41).

Essa dupla proposição - de que a educação só se efetiva em sua plenitude com a participação da sociedade e que seu sentido deve ser orientado para a promoção e exercício dos direitos humanos - estará presente em outras normas, nacionais e internacionais, tanto no que se refere à educação em geral como àquela a ser promovida nos espaços de privação de liberdade, e orientará algumas organizações que executam ações educativas na prisão, como apresentado adiante.

Ainda em relação ao artigo XXVI da Declaração Universal dos Direitos Humanos, destaca-se o uso do termo "instrução", que para Mannheim (1962), assim como "treinamento" e "ensino", são utilizados em referência à educação, mas têm significados diferentes.

De acordo com o autor, treinamento define "habilidades que precisam ser compreendidas e dominadas, mas que não inclui o princípio igualmente importante da independência, a necessidade de improvisar, com todas as implicações de julgamento, inteligência e liberdade que isto sugere” (1962, p. 36). Instrução é a transmissão de conhecimento, em que o destaque está no conteúdo que se comunica, e não nas pessoas envolvidas no processo, diferentemente do ensino. Neste último, a ênfase está no "professor e no aluno", além de haver a necessidade da consequência, ou seja, que o professor possa se certificar de que o aluno aprendeu o que foi transmitido. Também, no âmbito do ensino, “espera-se que o destaque, nessa interação, seja dado ora ao professor, no que ele tem a dizer e na maneira como o diz, ora ao aluno, ao desenvolvimento de sua compreensão e de sua 
iniciativa mental no apreender e transformar o que lhe está sendo apresentado" (1962, p. 36$37)$.

Esses termos, algumas vezes, são usados como sinônimos de educação ou sinônimos entre si. No caso da formulação do artigo XXVI, o uso do termo instrução para designar a orientação da ação, para lograr o pleno desenvolvimento da personalidade e o fortalecimento do respeito pelos direitos e liberdades fundamentais, remete ao conteúdo a ser adotado no processo de ensino e aprendizagem. Neste caso, a norma não apenas anuncia a garantia do direito, mas prescreve o conteúdo a ser adotado pela educação.

Considerando o caráter universal dos direitos humanos, significa dizer que a Declaração qualifica a educação a ser promovida a todas as pessoas, inclusive para aquelas que se encontram privadas de liberdade.

Da mesma forma, o Pidesc (1966), nos artigos 13 e 14, reafirma o conteúdo da Declaração Universal dos Direitos Humanos nesse tema e detalha alguns aspectos, como, por exemplo, a necessária "progressividade do ensino gratuito" para a educação secundária, modalidade que não era citada na Declaração de 1948 (item "b”, alínea 2, artigo 13).

A determinação da progressividade na gratuidade do ensino secundário obriga, de um lado, que os Estados Partes estabeleçam metas para atingir a universalidade desta oferta e, de outro, que não retrocedam em termos de atendimento.

O texto anuncia a necessidade de desenvolvimento de "uma rede escolar em todos os níveis de ensino", porém, também determina que a família tem o direito de escolher escolas não vinculadas à rede de ensino organizada pelo Estado, bem como impõe a este o dever de estabelecer os padrões mínimos de ensino e de zelar para que todos os estabelecimentos de ensino - públicos ou privados - o cumpram.

Ainda no plano internacional, no âmbito regional, há o Protocolo Adicional à Convenção Americana sobre Direitos Humanos sobre os Direitos Econômicos, Sociais e Culturais (Protocolo de San Salvador), adotado pela Conferência Interamericana de São Salvador, de 17 de novembro de 1988, e ratificado pelo Brasil em 1996, que prevê a possibilidade de apresentação de petição individual no caso de violação do direito à livre organização sindical (art. $8^{\circ}$, alínea “a”) e ao direito à educação (previsto no art. 13).

No caso do direito à educação, o conteúdo do Protocolo de San Salvador reafirma os termos do Pidesc. A inovação consiste na criação da Comissão Interamericana de Direitos Humanos, para investigar as denúncias, e também da Corte Interamericana de Direitos Humanos, que deve julgar as violações constatadas pela Comissão. Estas duas instâncias são consideradas mecanismos de exigibilidade e justiciabilidade, porque permitem a indivíduos, 
e também a organizações da sociedade civil, recorrerem a um tribunal internacional - um mecanismo de Justiça - para exigir um direito que deve ser concretizado por meio de políticas públicas nacionais.

O Protocolo reafirma o dever do Estado de investir o máximo de recursos disponíveis até alcançar, progressivamente - isto é, sem retrocessos -, a plena efetividade dos direitos econômicos, sociais e culturais, sob pena de ser responsabilizado.

É importante notar que, até a formulação do Protocolo de San Salvador, as possibilidades de exigibilidade e justiciabilidade, em âmbito internacional, eram reservadas aos direitos civis e políticos.

Não há dúvidas de que a inscrição dos direitos educativos em normas internacionais significou um importante marco no sentido de ampliar a garantia de acesso a estes direitos, deixando de ser um tema interno dos países, a ser tratado entre sociedade civil e governos, para tornar-se um compromisso assumido entre Estados, inclusive com a possibilidade de sanções.

No entanto, a redação de tais documentos possibilita cindir o direito à educação de maneira que os Estados sejam obrigados apenas a oferecer a instrução primária ou fundamental. Se de um lado a noção de progressividade impede retrocessos, de outro, não assegura a obrigatoriedade de universalização.

No caso brasileiro, a ampliação do acesso à educação formal tem ocorrido mais por pressão da sociedade civil ${ }^{12}$ do que pelo cumprimento espontâneo de compromissos internacionais assumidos pelo Estado, o que significa dizer que a inscrição em normas é mais um instrumento de luta política pela conquista do direito do que propriamente sua garantia.

\subsubsection{A educação de jovens e adultos}

O Pidesc, no item “d”, alínea 2, artigo 13, ao tratar da educação de jovens e adultos, não faz menção à obrigatoriedade, gratuidade ou progressividade na implementação desta modalidade. "Dever-se-á fomentar e intensificar, na medida do possível, a educação de base para aquelas pessoas que não receberam educação primária ou não concluíram o ciclo completo de educação primária", diz o Pacto.

Sobre este artigo, Comparato (2003) chama a atenção para a ambiguidade dos termos educação primária e educação secundária, que não trazem consigo a especificação das séries -

\footnotetext{
${ }^{12}$ SPOSITO, Marília Pontes. O povo vai à escola - a luta pela expansão do ensino público em São Paulo. Edições Loyola. São Paulo. 1984.
} 
ou período escolar - correspondentes. Isto é particularmente importante, porque o Pacto determina obrigatoriedade e gratuidade apenas para a educação primária, e esta varia de configuração em cada país. No Brasil, o número de anos obrigatórios de educação pública gratuita ampliou-se de quatro para oito anos em 1971, e para nove anos a partir de 2010. Em 1996, este período teve sua denominação alterada de "Ensino de $1^{\circ}$ grau" para "Ensino Fundamental”.

Além da ambiguidade apontada sobre o termo educação primária, em relação à educação de jovens e adultos, o Pacto fala ainda em educação de base sem especificar seu significado e propõe que este direito seja concretizado "na medida do possível". A redação específica sobre a educação de jovens e adultos, no Pidesc, restringiu o caráter universal do direito à educação, encontrado na Declaração Universal de 1948 e no item "a", alínea 2, capítulo 13, do próprio Pacto, que diz: “a educação primária deverá ser obrigatória e acessível gratuitamente a todos".

O direito à educação de pessoas jovens e adultas também tem sido tema de encontros e conferências internacionais, que, de um lado, reafirmam o direito desse grupo à educação e, por outro, estabelecem metas e propostas para serem adotadas pelos países que deles participam, como o Brasil ${ }^{13}$.

\subsubsection{A educação nas prisões}

A educação de pessoas adultas encarceradas, em âmbito internacional, é prevista no documento "Regras mínimas para o tratamento de prisioneiros", elaborado no $1^{\circ}$ Congresso das Nações Unidas sobre Prevenção do Crime e Tratamento de Delinquentes, realizado em Genebra, em 1955, aprovado pelo Conselho Econômico e Social da ONU por meio da sua resolução 663 C I (XXIV), de 31 de julho de 1957, e aditada pela resolução 2076 (LXII) de 13 de maio de 1977. No item 77, denominado "Educação e recreio", afirma o documento:

\footnotetext{
${ }^{13} \mathrm{O}$ direito educativo desse grupo foi reafirmado na I Conferência Internacional sobre Educação de Adultos Elsinore (Dinamarca, 1949); II Conferência Internacional sobre Educação de Adultos - Montreal (Canadá, 1960); Convenção relativa à luta contra as discriminações na esfera do ensino - adotada em 14 de dezembro de 1960, pela Conferência Geral da Organização das Nações Unidas para a Educação, a Ciência e a Cultura; III Conferência Internacional sobre Educação de Adultos - Tóquio (Japão, 1972); IV Conferência Internacional sobre Educação de Adultos - Paris (França, 1985); Declaração e o Plano de Ação de Educação para Todos Jomtien (Tailândia, 1990); Conferência Mundial de Direitos Humanos - Viena (Áustria, 1993); Declaração de Salamanca sobre Princípios, Política e Prática em Educação Especial - Salamanca (Espanha 1994); V Conferência Internacional sobre Educação de Adultos - Hamburgo (Alemanha, 1997); Cúpula Mundial de Educação - Dakar (Senegal, 2000); VI Conferência Internacional sobre Educação de Adultos - Belém (Brasil, 2009).
} 
1. Serão tomadas medidas para melhorar a educação de todos os presos em condições de aproveitá-la, incluindo instrução religiosa nos países em que isso for possível. A educação de analfabetos e presos jovens será obrigatória, prestando-lhe a administração especial atenção. 2. Tanto quanto possível, a educação dos presos estará integrada ao sistema educacional do país, para que depois da sua libertação possam continuar, sem dificuldades, a sua educação. (ONU, 1955).

Ainda que possa ser interpretada como o reconhecimento do direito à educação para as pessoas presas, a formulação comporta aspectos ambíguos em relação ao papel do Estado na promoção da educação e também sobre a própria noção de educação anunciada. Anuncia a obrigatoriedade do Estado apenas em relação à alfabetização, torna facultativa a integração da educação ofertada nas prisões ao sistema regular de ensino e inclui a instrução religiosa entre as medidas a serem adotadas para "melhorar a educação de todos os presos". O texto oscila entre afirmar o direito à educação formal e considerar educação qualquer prática que envolva treinamento, ensino ou instrução.

A Resolução 1990/20, do Conselho Econômico e Social da ONU torna mais evidente o que este organismo internacional considera educação nas prisões, como a responsabilidade por sua formulação e realização. O texto recomenda que os "Estados-membros, as instituições competentes, os serviços de assessoramento docente e outras organizações formulem a educação nos estabelecimentos penitenciários". Da mesma forma, anuncia os objetivos da educação nas prisões ao recomendar que os

estados-membros proporcionem diversos tipos de educação que contribuam de maneira apreciável à prevenção do delito, a inserção social dos reclusos e a redução dos casos de reincidência, por exemplo, alfabetização, formação profissional, educação permanente para a atualização de conhecimentos, ensino superior e outros programas que fomentem o desenvolvimento humano dos reclusos. (ONU, 1990)

Entre os princípios que os Estados Membros devem observar na formulação de políticas de educação, a Resolução ainda aponta:

[...] b)Todos os reclusos devem gozar de acesso a educação, incluindo programas de alfabetização, educação básica, formação profissional, atividades criativas, religiosas e culturais, educação física e desportivas, educação social, ensino superior e serviços de biblioteca; e) a educação deve constituir o elemento essencial do regime penitenciário[...]; f) o ensino profissional deve orientar-se ao desenvolvimento mais amplo da pessoa e responder às tendências do mercado de trabalho; h) sempre que possível deve-se permitir a participação dos reclusos em atividades educativas fora dos estabelecimentos penitenciários; i) quando a instrução deve ocorrer no estabelecimento penitenciário, se deve contar com a maior participação da comunidade externa [...]. 
Na resolução 1990/24, o mesmo Conselho recomenda que seja formulado um plano de trabalho, de maneira que as Nações Unidas se envolvam de forma mais prática e operacional no desenvolvimento, pelos Estados Membros, de ações no âmbito da prevenção do delito e justiça penal.

Por fim, a resolução 45/111 estabelece os Princípios básicos relativos ao tratamento de reclusos, que reafirma a Declaração Universal dos Direitos Humanos ao precisar que a educação nas prisões deve ser orientada para o pleno desenvolvimento da personalidade humana.

A Resolução 1990/20 introduz uma nova perspectiva aos objetivos da educação nas prisões ao colocar, simultaneamente ao desenvolvimento da personalidade humana dimensão individual -, o "desenvolvimento humano dos reclusos", proposição que tem implicações de ordem coletiva.

Amartya Sen (2000, p. 57) define desenvolvimento humano como processo de expansão das liberdades como forma de adquirir condições de ter vida saudável e digna, em todos os seus aspectos, e nas dimensões da vida coletiva e individual. Neste caso, a liberdade é considerada o fim primordial e o principal meio de desenvolvimento, ou, em outras palavras, desempenha, respectivamente, "papel constitutivo e papel instrumental" neste processo.

O papel constitutivo da liberdade, ou seu caráter de finalidade, baseia-se na premissa que toda a organização social - inclusive a prisão?! - deve ser orientada para garantir o bemestar dos seres humanos, em suas múltiplas dimensões, e aí residiria o desenvolvimento, ou seja, na busca da ausência de privações para as pessoas. Assim como os direitos humanos, esta noção de desenvolvimento é orientada para garantir a dignidade das pessoas.

Por essa concepção, “a contribuição do crescimento econômico tem de ser julgada não apenas pelo aumento de rendas privadas, mas também pela expansão de serviços sociais (incluindo, em muitos casos, redes de segurança social) que o crescimento econômico pode possibilitar" (SEN, 2000, p. 57).

A liberdade como meio ou no seu papel instrumental para o desenvolvimento, é interpretada de diversas formas; entre elas, Sen $(2000, \text { p.55 })^{14}$ destaca as liberdades políticas;

\footnotetext{
${ }^{14}$ As liberdades políticas estão relacionadas aos direitos de participação na vida pública - o voto e a fiscalização dos governantes, liberdade de expressão, entre outros. As liberdades econômicas são as oportunidades que os indivíduos têm para utilizar recursos econômicos para consumo, produção ou troca. As oportunidades sociais são as disposições estabelecidas pela sociedade e que influenciam a possibilidade de os indivíduos viverem melhor. As garantias de transparência referem-se à liberdade de serem estabelecidas relações, no âmbito social, baseadas na transparência, fator que, entre outras possibilidades, pode ser um inibidor da corrupção. Por fim, a segurança
} 
as facilidades econômicas; as oportunidades sociais; as garantias de transparência e, por último, a segurança protetora. $\mathrm{O}$ acesso à educação, neste caso, estaria entre as oportunidades sociais e se constituiria como fator condicionante para o exercício das demais liberdades.

Nesse sentido, os processos educativos não se reduzem aos da escolarização. Rompese a lógica de que para se atingir o desenvolvimento deve-se ter como fim manter crescimento econômico com crescimento de escolaridade. Ao considerar a liberdade como meio e fim, a perspectiva do Desenvolvimento Humano condiciona a participação da pessoa como agente fundamental do desenvolvimento. Desenvolvimento se conquista tendo a participação como processo central, e esta participação é decorrente de uma educação que valoriza o ser humano como agente do seu próprio desenvolvimento e o da sociedade.

A introdução da noção de desenvolvimento humano é coerente com outros aspectos da Resolução 1990/20. O primeiro deles é anunciar efetivamente que a compreensão de educação adotada não se restringe aos processos de elevação de escolaridade - afirma-se as práticas de educação não formais também como legítimas - sem, contudo, atenuar a responsabilidade do Estado para com a promoção do direito à educação. A participação de "outras organizações" está prevista na formulação das políticas educacionais, ficando a cargo do Estado a sua efetivação. Nota-se que a expressão "políticas educacionais" também é utilizada pela primeira vez entre as normas verificadas, afirmando a necessidade do caráter universal - extensivas a todas as unidades prisionais - das ações a serem empreendidas.

O conceito de desenvolvimento humano, considerado expansão das liberdades, também pode ser constatado na transgressão de uma característica essencial à instituição prisional, que é a separação física entre criminosos e pessoas de bem (FOUCAULT, 1987 e 1979; Durkheim, 1995), ao propor que os reclusos saiam para participar de atividades educativas e, no sentido inverso, que pessoas de fora entrem com o mesmo objetivo.

Por fim, a educação de pessoas jovens e adultas encarceradas está prevista na Declaração de Hamburgo, firmada ao final da $5^{\text {a }}$ Conferência Internacional sobre Educação de Jovens e Adultos (Confintea V), realizada na Alemanha em julho de 1997, que avança quanto ao reconhecimento do direito à educação, formal e não formal, ao afirmar o direito à aprendizagem a todas as pessoas, destacando os grupos historicamente excluídos no item 11 Alfabetização de adultos: "A preocupação mais urgente é estimular oportunidades de aprendizagem a todos, em particular, os marginalizados e excluídos".

protetora refere-se a uma rede de segurança social destinada a garantir o bem-estar das pessoas em situações de vulnerabilidade, como catástrofes ou mesmo desemprego. (SEN, 2000, p. 55 a 57). 
No "Plano de Ação para o futuro", aprovado nesse encontro, a educação das pessoas encarceradas é tratada de forma explícita no "Tema 8", que no item 43 afirma a educação como um direito universal que tem sido negado a muitos grupos, entre eles, "os presos"; e, dando consequência a esta constatação, prevê, no item 47:

\begin{abstract}
Reconhecer o direito de todas as pessoas encarceradas à aprendizagem: a) proporcionando a todos os presos informação sobre os diferentes níveis de ensino e formação, e permitindo-lhes acesso aos mesmos; b) elaborando e implementando nas prisões programas de educação geral com a participação dos presos, a fim de responder a suas necessidades e aspirações em matéria de aprendizagem; c) facilitando que organizações não governamentais, professores e outros responsáveis por atividades educativas trabalhem nas prisões, possibilitando assim o acesso das pessoas encarceradas aos estabelecimentos docentes e fomentando iniciativas para conectar os cursos oferecidos na prisão aos realizados fora dela. (DECLARAÇÃO DE HAMBURGO, 1997, tema 8, item 47).
\end{abstract}

O texto da Declaração de Hamburgo alarga a concepção dos direitos educativos ao explicitar o acesso à informação sobre os diferentes níveis e formação também como um direito; estabelecer a participação dos presos na formulação dos programas de educação e indicar a necessidade da atuação de organizações não governamentais e educadores no ambiente prisional.

Além de transgredir o princípio da separação entre os de dentro e os de fora, o texto sugere a quebra dos segredos (FOUCAULT, 1987), ou a retirada do "manto do silêncio" (SALLA, 1997), ao determinar a circulação das informações e a participação dos presos na organização dos programas de educação.

A $6^{\text {a }}$ Conferência Internacional sobre Educação de Jovens e Adultos (Confintea VI), realizada no Brasil - Belém (PA) - em dezembro de 2009, por meio do documento que sintetizou os compromissos assumidos pelos governos, intitulado: "Aprovechar el poder y el potencial del aprendizaje y la educación de adultos para un futuro viable - Marco de acción de Belém”, reafirma os compromissos estabelecidos no encontro anterior e reconhece que a educação de adultos representa um componente importante no processo de aprendizagem ao longo da vida, abarcando as formas formais, não formais e informais de aprendizagem (UNESCO, 2009, p. 3).

A educação de adultos encarcerados foi objeto de compromissos específicos no campo da Alfabetização, no "item e", ao ser incluída entre os grupos prioritários a serem contemplados: "centrar la acción de alfabetización en las mujeres y en sectores de población altamente desfavorecidos, entre ellos los pueblos indígenas y las personas encarceladas, con un hincapié general en las poblaciones rurales" (UNESCO, 2009, p. 4). 
E também no eixo "Participação, inclusão e equidade", "item g": "impartir educación de adultos en los centros penitenciarios en todos los niveles apropiados" (2009, p. 7).

A redação do Plano de Ação do encontro de Belém é mais objetiva ao determinar que a educação de adultos deve ser implementada em todos os cárceres e em todos os níveis apropriados e por não condicionar, no mesmo item, a participação de pessoas presas e de organizações da sociedade civil na sua organização, como acontecia na Declaração de Hamburgo, o que dava margem a interpretações que referendaram a transferência da responsabilidade do Estado para a sociedade civil organizada ou para as próprias pessoas presas. Considerando que são os Estados Partes, representados por seus governantes, que assinam o Plano de Ação, é bastante evidente a responsabilidade do Estado na efetivação da proposição.

A participação da sociedade civil, "das partes interessadas do mercado de trabalho", dos educandos e dos educadores é considerada condição para a formulação de um enfoque holístico e integrado, que deve nortear a educação de adultos em geral, e não apenas das pessoas encarceradas (2009, p. 7).

Também essa estratégia de redação é interessante, pois aproxima a educação de pessoas encarceradas do campo da educação de jovens e adultos em geral, retirando-a da sua redoma de especificidade absoluta, que terminava por excluí-la das conquistas - ainda insuficientes, é verdade - da modalidade educação de jovens e adultos, como será demonstrado ao longo deste trabalho.

No Informe $^{15}$ sobre educação nas prisões, apresentado ao Conselho de Direitos Humanos da ONU em abril de 2009, o relator especial da ONU para o Direito à Educação, Vernor Muñoz (2009, p. 5; 11), avaliou de maneira pessimista o efeito das normas internacionais sobre a efetivação dos direitos educativos das pessoas encarceradas:

[...] la situación de la educación tiende con demasiada frecuencia a oscilar entre "mala" y "muy mala", es preciso reconocer plenamente el número de programas educativos de calidad excepcional que, a la luz de las observaciones de los propios reclusos, son resultado de iniciativas individuales y de un extraordinario compromiso más que producto de la política del Estado o de una determinada institución [...] Las normas jurídicas y políticas internacionales seguirán teniendo un efecto limitado mientras la comunidad internacional, cuya actuación intentan

\footnotetext{
${ }^{15}$ Conforme Muñoz (2009, p. 20), o documento foi elaborado com base em informações recebidas por governos e organizações da sociedade civil dos seguintes países: Albania, Alemaha, Argélia, Argentina, Brasil, Bulgária, Burkina Faso, Costa Rica, Cuba, Chile, Chipre, Equador, Egito, Eslováquia, Grécia, Guatemala, Guiana, Hungría, Irlanda, Itália, Japão, Kazaquistão, Letônia, Líbano, Lituania, Mauricio, México (Comissão Nacional de Direitos Humanos), Noruega, Omán, Peru, Polônia, Reino Unido da Grã Bretanha e Irlanda do Norte, República Árabe Síria, República Checa, República de Moldova, República Dominicana, Romênia, Cingapura, Suíça, Suriname, Suécia, Trinidad e Tabago, Tunísia, Ucrânia y Uzbequistão.
} 
regular, no apoye plenamente los principios en que se fundan. En lo que atañe a las personas privadas de libertad, ese apoyo está tardando en llegar. La elaboración de normas internacionales jurídicamente vinculantes y de orientaciones conexas sobre la educación en los establecimientos penitenciarios es por cierto bienvenida y contribuye a documentar el debate internacional sobre el tratamiento de los reclusos, especialmente en lo que respecta a su acceso a la educación. Pese a que los Estados han desempeñado un papel fundamental en la elaboración de esas normas, su pleno cumplimiento sigue siendo la excepción. (Vernor Muñoz, 2009, p. $5 ; 11)$.

Conforme Muñoz, o não cumprimento das normas que determinam os direitos educativos é a regra em todo o mundo, mesmo nos países que experimentaram a prisão disciplinar (FOUCAULT, 1987) e depois, mantendo características desse modelo, vivenciaram o paradigma "penal-previdenciário" no período do pós-guerra até a metade dos anos 1970, conforme definido por Garland (2008, p. 211), ao descrever as condições das prisões britânicas e norte-americanas: "as propostas de reforma mais recorrentes concerniam ao aperfeiçoamento dos serviços voltados à reabilitação, à redução de controles opressivos e ao reconhecimento dos direitos de suspeitos e presos".

Retomando a discussão anterior, as razões que possibilitaram à instituição prisão manter suas características repressivas e arbitrárias, conforme descrita por Foucault (1987), paralelamente aos avanços normativos no que se refere ao reconhecimento dos direitos dos presos, compõem um novo cenário do cotidiano prisional, que Chantraine (2006) denomina “prisão pós-disciplinar”, ao analisar as políticas penitenciárias do Canadá no final da década de 1990 e primeiros anos deste século.

Chantraine também afirma que a demanda por direitos dos presos, fundada não na melhoria das condições de detenção, mas no reconhecimento dos direitos de cidadania dos presos, foi um "motor importante desse processo" (2006, p. 86). Ao mesmo tempo em que o estabelecimento dos direitos foi se constituindo em instrumento de proteção contra o abuso do poder por parte da administração penitenciária, permitiu à instituição "integrar, domesticar e sobreviver a essa atividade democrática de contestação” (2006, p. 87).

[...] essa garantia permanece relativa: amplos leques de direitos promovidos no interior desse quadro carcerário-securitário permanecem ainda submetidos e condicionados a esse quadro de segurança, constituindo assim um recurso ${ }^{16}$ para a antecipação, a orientação e o controle das condutas. (CHANTRAINE, 2006, p. 88).

A domesticação dos direitos anunciados nas normas deu-se por meio de três mecanismos característicos à prisão pós-disciplinar: a trilogia segurança ativa-liderança-

\footnotetext{
${ }^{16}$ Grifo do autor.
} 
ordem comunicacional; os usos do fator "risco" e o sistema de privilégios (CHANTRAINE, 2006, p. 79).

Em síntese, o autor identifica que a administração das prisões alterou a forma de exercício do poder, abdicando, em parte, do uso da violência e ampliando sua "capacidade de influenciar" a população carcerária. Para tanto, lançou mão da segurança ativa, caracterizada pela busca de informações sobre os presos, a fim de tornar previsíveis suas reações. Ao mesmo tempo, investiu no fortalecimento de lideranças internas ao grupo, responsáveis pelas negociações entre administração e população e, também, bastante úteis na aquisição de informações individuais. Fechando a trilogia, foram estabelecidos canais de comunicação, como os comitês de detentos, que legitimam negociações pacíficas, sempre intermediadas pelas lideranças.

O fator "risco de reincidência", formulado tecnicamente por especialistas, sobretudo psicólogos, também, de certa forma, alivia a tensão da relação entre agentes da segurança e presos, uma vez que a avaliação do comportamento é de responsabilidade dessa figura técnica, revestida de legitimidade por um saber científico, portanto, socialmente considerada isenta de julgamentos arbitrários.

Por fim, operando de forma harmônica com os mecanismos anteriores, há o sistema de privilégios, que opera de maneira bastante simples, transformando os direitos anunciados nas normas, em privilégios concedidos em razão do comportamento.

Schilling (1991, p. 30), ao se valer da ideia de Foucault, segundo a qual o exercício do poder, operando por meio dos micro-organismos de poder existentes nas instituições, conta e, ao mesmo tempo, estimula a emergência de ilegalidades, toleradas e úteis para a manutenção da ordem, afirma: “O sistema, portanto, só se manteria em seu equilíbrio instável (aliás, a única forma de equilíbrio existente) pela existência dessas margens de ilegalidade (transgressões), que, além de garantir a vazão de forças que de outra forma seriam explosivas, garantem o próprio funcionamento das organizações que o compõem."

O sistema de privilégios, descrito por Chantraine, também pode ser interpretado como um “pequeno mecanismo penal”, tal qual descrito por Foucault (1987, p. 159):

$\mathrm{Na}$ essência de todos os sistemas disciplinares, funciona um pequeno mecanismo penal. É beneficiado por uma espécie de privilégio de justiça, com suas leis próprias, seus delitos especificados, suas formas particulares de sanção, suas instâncias de julgamento. As disciplinas estabelecem uma "infrapenalidade"; quadriculam um espaço deixado vazio pelas leis; qualificam e reprimem um conjunto de comportamentos que escapava aos grandes sistemas de castigo por sua relativa indiferença. 
Em que pese o fato de a análise proposta por Chantraine relacionar-se às prisões do Canadá, cujo contexto socioeconômico é absolutamente diferente do Brasil, gerando, portanto, condições de encarceramento também diferentes (RUCHE \& KIRCHHEIMER, 2004; GARLAND, 2005), inclusive no que se refere às suas características ao longo do tempo, ainda assim é possível reconhecer elementos da prisão pós-disciplinar tanto nas possibilidades de acesso quanto de realização das atividades educativas identificadas nesta pesquisa. Também, a educação informal, exercida por grupos organizados de presos, remete tanto às considerações de Chantraine como retoma a constatação de Foucault sobre os pequenos mecanismos penais que se criam no interior das instituições disciplinares, conforme será demonstrado ao longo da exposição dessa pesquisa.

\subsubsection{O âmbito nacional}

A educação escolar de jovens e adultos no Brasil compreende ações de alfabetização, cursos e exames supletivos nas etapas de ensinos fundamental e médio, bem como processos de educação a distância realizados via rádio, televisão ou materiais impressos.

Em âmbito nacional, os direitos educativos das pessoas jovens e adultas estão assegurados em lei desde a Constituição de $1824^{17}$; naquele momento, a determinação de “gratuidade do ensino primário a todos os cidadãos" estava ancorada à definição de cidadania:

[...] não se consideravam na terminologia adotada cidadãos ativos os criados de servir, os jornaleiros, os caixeiros das casas comerciais, enfim qualquer cidadão comum com rendimentos líquidos anuais inferiores ao valor de cento e cinquenta alqueires de farinha de mandioca. Numa palavra, toda a população trabalhadora do país, os escravos naturalmente incluídos. É assim que "garantia-se instrução primária gratuita a todos os cidadãos, mas a grande maioria da população permaneceria inculta por muito tempo ainda. (BEISIEGEL, 1974, p. 43 ).

$\mathrm{Na}$ República, a educação de jovens e adultos continuou prevista nas constituições nacionais, sendo justificada pela necessidade de formação de uma população apta à nova ordem social que se queria desenhar.

\footnotetext{
${ }^{17}$ De acordo com Beisiegel (1974, p. 38), o texto constitucional expressava a contradição vivida pelas elites dominantes e governantes, do período: “... mediante a subordinação dos direitos de igualdade às imposições do direito de propriedade, o liberalismo, no Brasil, nestes primeiros tempos, realizaria a difícil conciliação entre os ideais de igualdade e a base escrava da economia colonial. A escravidão daria testemunho mais agudo das limitações das teses liberais no Brasil e explicaria muitas das suas peculiaridades".
} 
A escolaridade obrigatória associava-se coerentemente às demais reivindicações da época: era condição de formação de uma consciência popular esclarecida, era meio de valorização do trabalho livre, estava na raiz do processo de emancipação da mulher e, sobretudo, era condição básica de realização do progresso. (BEISIEGEL,1974, p. 55).

$\mathrm{Na}$ Constituição de 1988, este direito está previsto no Capítulo III, Seção I - Da Educação, artigo 208, inciso I, que garante a provisão pública de "Ensino Fundamental obrigatório e gratuito, assegurada, inclusive, sua oferta para todos os que a ele não tiveram acesso na idade própria".

A Lei de Diretrizes e Bases da Educação Nacional (LDB), que regulamenta os dispositivos constitucionais referentes à educação, contempla a escolarização básica desse segmento na Seção V do Capítulo II, Educação Básica, que determina aos sistemas de ensino assegurar cursos e exames que proporcionem oportunidades educacionais apropriadas aos interesses, condições de vida e trabalho dos jovens e adultos. Estipula ainda que o acesso e a permanência dos trabalhadores na escola sejam viabilizados e estimulados por ações integradas dos poderes públicos.

Não há, na Lei de Diretrizes e Bases da Educação, nenhuma referência específica à promoção da educação na prisão, contudo, é interessante notar que a mesma lei, no Capítulo II, Seção V, artigo 37, § $2^{\circ}$, determina a integração dos poderes públicos para assegurar o acesso e a permanência dos "trabalhadores na escola", formulação que sugere a condicionalidade do exercício do direito à educação a atividades produtivas ou ao mercado de trabalho.

Em 2000, o Conselho Nacional de Educação aprovou o Parecer 11 e a Resolução 1, que fixaram Diretrizes Curriculares Nacionais para a Educação de Jovens e Adultos, regulamentando alguns aspectos da LDB. A Resolução delimitou a idade mínima para ingresso na educação de jovens e adultos aos 14 anos para a etapa fundamental do ensino, e 17 para o ensino médio. No texto do Parecer 11, o conselheiro Carlos Jamil Cury afirma que a especificidade da modalidade EJA impõe que receba tratamento consequente, e destaca sua função equalizadora:

A EJA vai dar cobertura a trabalhadores e a tantos outros segmentos sociais como donas de casa, migrantes, aposentados e encarcerados A reentrada no sistema educacional dos que tiveram uma interrupção forçada seja pela repetência, seja pelas desiguais oportunidades de permanência ou outras condições adversas deve se saudada como uma reparação corretiva, ainda que tardia, de estruturas arcaicas [...] Para tanto, são necessárias mais vagas para estes "novos" alunos e "novas" alunas, demandantes de uma nova oportunidade de equalização. 
Já a Lei 10.172/2001, do Plano Nacional de Educação (PNE, 2001), definiu 26 metas prioritárias para o decênio 2001-2011, e a educação nas prisões foi inscrita na $17^{\mathrm{a}}$ meta:

Implantar, em todas as unidades prisionais e nos estabelecimentos que atendam adolescentes e jovens infratores, programas de educação de jovens e adultos de nível fundamental e médio, assim como de formação profissional, contemplando para esta clientela as metas $\mathrm{n}^{\circ} 5$ (financiamento pelo MEC de material didático-pedagógico) e $\mathrm{n}^{\mathrm{o}} 14$ (oferta de programas de educação à distância).

Note-se que o Plano Nacional de Educação data de 2001 e, apenas em março de 2005, o Ministério da Educação anunciou sua participação, em parceria com o Ministério da Justiça e a Secretaria de Direitos Humanos da Presidência da República, da definição de projeto educativo destinado às populações carcerárias (LEITÃO, 2005).

De maneira mais precisa, do ponto de vista formal, a educação nas prisões é assegurada na Lei no 7.210 (11/7/1984), denominada Lei de Execução Penal (LEP, 1984), que em seu Capítulo II, intitulado "Da Assistência”, Seção V, artigos 17 a 21 determina:

A assistência educacional compreenderá a instrução escolar e a formação
profissional do preso e do internado; o ensino de $1^{\circ}$ grau será obrigatório,
integrando-se no sistema escolar da Unidade Federativa; o ensino profissional será
ministrado em nível de iniciação ou de aperfeiçoamento técnico; a mulher
condenada terá ensino profissional adequado à sua condição; as atividades
educacionais podem ser objeto de convênio com entidades públicas ou particulares,
que instalem escolas ou ofereçam cursos especializados; em atendimento às
condições locais, dotar-se-á cada estabelecimento de uma biblioteca, para uso de
todas as categorias de reclusos, provida de livros instrutivos, recreativos e didáticos.

Conforme o artigo exposto, a Lei de Execução Penal restringe a obrigação do Estado em ofertar apenas o Ensino Fundamental e também expõe a possibilidade da transferência das responsabilidades estatais para organizações privadas. No entanto, o aspecto mais restritivo, no que se refere à promoção da escolarização dos prisioneiros, é a desvalorização das atividades de educação em relação às atividades consideradas trabalho. Para este segundo grupo, é concedida a remição na proporção de um dia a menos na pena para cada três dias de trabalho. 


\subsubsection{Programa Nacional de Direitos Humanos}

Em 1996, o governo federal, cumprindo determinação da Conferência Mundial de Direitos Humanos, realizada em Viena (1993), lançou o Programa Nacional de Direitos Humanos (PNDH - I), e a Educação era citada entre as "Propostas de Ações Governamentais" de três diferentes maneiras.

A primeira delas diz respeito à educação como meio de capacitação dos profissionais da área da segurança e lideranças populares, no item Conscientização e mobilização pelos direitos humanos. Educação e Cidadania. Bases para uma cultura de Direitos Humanos, entre as ações de Curto prazo:

\footnotetext{
Apoiar programas de informação, educação e treinamento de direitos humanos para profissionais de direito, policiais, agentes penitenciários e lideranças sindicais, associativas e comunitárias, para aumentar a capacidade de proteção e promoção dos direitos humanos na sociedade brasileira. (PNDH - I, 1996, p. 13-14).
}

A segunda, como instrumento de formação da sociedade em geral, no item Produção e distribuição de informações e conhecimento. Educação e Cidadania. Bases para uma cultura de Direitos Humanos, entre as ações de Curto prazo:

\footnotetext{
Criar e fortalecer programas de educação para o respeito aos direitos humanos nas escolas de primeiro, segundo e terceiro grau, através do sistema de 'temas transversais' nas disciplinas curriculares, atualmente adotado pelo Ministério da Educação e do Desporto, e através da criação de uma disciplina sobre direitos humanos. (PNDH - I, 1996, p. 13).
}

Por fim, no item Penas privativas de liberdade, entre as ações de Médio prazo, a educação aparece como meio de ressocialização da população encarcerada: "Promover programas de educação, treinamento profissional e trabalho para facilitar a reeducação e recuperação do preso"(PNDH - I, 1996, p. 11).

Note-se que a educação não aparece uma única vez como um direito humano, mas sempre como um instrumento, ora de capacitação profissional em direitos humanos, outras de formação para os direitos humanos ou ainda para a "modificação" das pessoas presas.

Em 2002, o governo federal lançou a segunda edição do Programa Nacional de Direitos Humanos (BRASIL, 2002), contendo elementos de "revisão" e "atualização" em relação à primeira versão. A principal delas foi a introdução dos direitos econômicos, sociais e culturais, enunciados e detalhados em atividades a serem avaliadas anualmente. 
Especificamente sobre a educação, o PNDH - II reafirma o texto constitucional e aponta ações para a universalização do acesso ao ensino público e também para a melhoria de sua qualidade. Também permaneceram, ou foram ampliadas, ações de educação como meio de capacitação e formação em direitos humanos, sobretudo para servidores públicos do campo da segurança.

Não há nenhuma proposição que afirme o direito de acesso à educação para as pessoas presas, e o tema é tratado de forma bem genérica e imprecisa no item 79: "Implementar políticas visando a garantir os direitos econômicos, sociais e culturais das pessoas submetidas à detenção" (PNDH - II, 2002, p. 24), e no item 91: "Promover programas educativos, culturais, de treinamento profissional e de apoio ao trabalho do preso, com vistas a contribuir para sua recuperação e reinserção na sociedade" (2002, p. 26).

Em dezembro de 2009, o governo federal apresentou a terceira edição do Progarma Nacional de Direitos Humanos (SEDH, 2010). A garantia da educação nas prisões está determinada no eixo Eixo Orientador IV "Segurança Pública, Acesso à Justiça e Combate à Violência", Diretriz 16: "Modernização da política de execução penal, priorizando a aplicação de penas e medidas alternativas à privação de liberdade e melhoria do sistema penitenciário", Ação programática a): "Elaborar projeto de reforma da Lei de Execução Penal (Lei no 7.210/1984), com o propósito de: [...] Instituir a obrigatoriedade da oferta de ensino pelos estabelecimentos penais e a remição de pena por estudo" (SEDH, 2010, p. 135).

É inegável o avanço dessa última versão do Programa em relação ao reconhecimento formal do direito à educação, inclusive apontando para a necessidade de reformulação da Lei de Execução Penal, que, como já exposto anteriormente, é ambígua neste tema. Embora não esteja explícito, no entanto, o texto parece tratar da garantia da educação formal, não fazendo menção às práticas não formais de educação desenvolvidas no ambiente prisional.

A educação não formal é tratada no Eixo orientador V - Educação e Cultura em Direitos Humanos, mas sua oferta, no contexto de privação de liberdade, é vinculada apenas às medidas socioeducativas cumpridas por adolescentes (2010, p. 159-161).

\subsubsection{Programa Estadual de Direitos Humanos do Estado de São Paulo}

O Programa Nacional de Direitos Humanos de 1996 determinou a elaboração de Planos Estaduais e Municipais de Direitos Humanos, com o objetivo de "implementar nos Estados as propostas de ações governamentais incluídas no $\mathrm{PNDH}$, mas também propor novas medidas 
para proteção dos direitos humanos que contemplem as características específicas de cada Estado", conforme afirmado no Prefácio do Programa Estadual de Direitos Humanos do Estado de São Paulo (PEDH-SP, 1997). De acordo com este documento, a decisão de elaborar planos estaduais foi tomada pelos secretários estaduais de Justiça, em maio de 1997, durante o $2^{\circ}$ Fórum Nacional de Secretários de Estado da Justiça, em reconhecimento "à importância dos governos estaduais na implementação do PNDH".

Ainda de acordo com o prefácio do PEDH-SP (1997), São Paulo foi o primeiro Estado a elaborar seu programa de Direitos Humanos, conferindo "status de política pública aos direitos humanos e comprometendo-se a formular e implementar um programa de ação para proteger e promover os direitos humanos".

Como o PNDH, o programa paulista afirma a indivisibilidade dos direitos humanos, reconhece a extrema desigualdade de renda verificada na sociedade brasileira, admite que "é impossível promover os direitos humanos sem que os problemas estruturais do desemprego, do acesso a terra, da educação, da saúde e do meio ambiente sejam objeto de políticas e programas governamentais sejam superados". No entanto, exatamente como a primeira versão nacional, sobrepõe os direitos individuais aos coletivos, ao afirmar que "para que a população possa assumir que os direitos humanos são direitos de todos e as entidades da sociedade civil possam lutar por esses direitos e atuar em parceria com o Estado, é fundamental que seus direitos civis e políticos sejam garantidos".

O programa é estruturado em três capítulos. O primeiro, intitulado Construção da democracia e promoção dos direitos humanos; o segundo, Direitos econômicos, sociais, culturais e ambientais, no qual há um item dedicado à "Educação"; e por último, o capítulo Direitos civis e políticos.

O item "Educação" contém sete ações, que incluem a "melhoria do ensino público" por meio da valorização dos profissionais da educação; fortalecimento dos mecanismos de participação de pais e alunos na gestão escolar e programas de monitoramento e eliminação da evasão escolar.

Especificamente sobre o direito de acesso à educação, há dois itens; o primeiro estabelece: 
Garantir o acesso, o reingresso, a permanência e o sucesso de todas as crianças e adolescentes $^{18}$ nos ensinos Fundamental e Médio, por meio de ações como a implementação de classes de aceleração, a recuperação paralela e outras medidas, entre as quais a concessão de incentivo às famílias carentes que mantiverem seus filhos na escola. (PEDH-SP, 1997, item "Educação").

A segunda indicação sobre o tema diz, simplesmente "promover cursos de alfabetização de jovens e adultos".

A formulação de tais proposições contraria o fundamento básico do conceito de direitos humanos, que é a universalidade da garantia do direito em questão, no caso, a educação. Note-se que o acesso aos ensinos fundamental e médio é previsto como direito, garantido e até estimulado pelo poder público, apenas para crianças e adolescentes. Aos jovens e adultos cabe apenas a promoção de cursos de alfabetização.

Nesse caso, a própria redação estabelece diferentes compromissos do poder público com a efetivação da proposta. Para crianças e adolescentes, pretende-se "garantir o acesso, reingresso, permanência e sucesso" no sistema educacional; a jovens e adultos, o Estado compromete-se apenas a "promover" cursos de alfabetização. Não são mencionadas nem a garantia de cursos de alfabetização a todas as pessoas adultas analfabetas tampouco a garantia de acesso ao ensino regular fundamental ou médio.

No programa estadual, a educação é citada também entre as ações estabelecidas no capítulo dedicado aos direitos civis e políticos, como forma de preparar, capacitar lideranças comunitárias para a defesa dos direitos humanos; profissionais da área de segurança para atuarem no gerenciamento de crises e negociação de conflitos coletivos, assim como para a atuação de policiais. Há também, neste capítulo, um conjunto de ações que visam à oferta de oportunidades educacionais para grupos populacionais específicos, como a população encarcerada, conforme item 169:

[...] a facilitação do acesso à educação, ao esporte e à cultura, fortalecendo projetos como Educação Básica, Educação pela Informática, Telecurso 2000, Teatro nas Prisões e Oficinas Culturais, privilegiando parcerias com organizações não governamentais e universidades. (PEDH-SP,1997, item 169).

Mantém-se a tendência verificada no final da década de 1990, no Programa Nacional, de vincular a educação a processos de ressocialização, com vistas à capacitação profissional, mas também há a previsão de iniciativas à escolarização básica, e atividades culturais. Note-se que o termo utilizado é "facilitação" e, não, "garantia" do acesso. A formulação do texto

\footnotetext{
${ }^{18}$ Destaque da autora.
} 
hesita na afirmação dos direitos educativos das pessoas encarceradas e é ambíguo em relação à obrigação do Estado na promoção das ações anunciadas, ao afirmar que serão privilegiadas as parcerias com as organizações da sociedade civil, sem especificar os objetivos, a abrangência e as condições para sua celebração, conforme reflexões propostas no Capítulo 4 deste trabalho.

\subsection{O que é educação nas prisões - possibilidades de análise}

O conjunto de normas, nacionais e internacionais, bem como os planos e programas de direitos humanos expostos, expressam diferentes compreensões, e anseios, em relação à natureza da educação ofertada nas prisões de pessoas jovens e adultas, bem como sobre seus objetivos.

Também expressam diferentes visões sobre o grupo ao qual se destina a educação. Sujeitos de direitos? Pessoas que precisam ser regeneradas (MANNHEIM, 1962)? Vítimas de um sistema socioeconômico desigual com direito à reparação?

A essas visões, poderiam ser acrescentadas outras, identificadas por diferentes autores com base nas políticas penitenciárias adotadas no mundo ocidental a partir da década de 1980 . Pessoas inúteis, sobrantes (BAUMAN, 1999) de um contexto histórico, que devem ser mantidas fora de circulação, ocupando seu tempo - não importa como - apenas para evitar possíveis transtornos?

A cada uma dessas visões corresponde não apenas a formulação das ações educativas no ambiente prisional, mas também as possibilidades concretas de sua realização.

Antes, porém, de analisar as atividades, é necessário considerar o que é compreendido como educação no ambiente prisional, ou, como estão dispostas as oportunidades educativas na prisão. Embora o objeto desta pesquisa sejam as práticas não formais de educação empreendidas por organizações da sociedade civil nas prisões, dada a multiplicidade e a sobreposição de significados que assume o termo "educação" no ambiente prisional, a seguir serão apresentadas algumas reflexões que permitirão a distinção entre as práticas formais, não formais e informais que envolvem a educação. São considerações, possibilidades de análises, não formuladas exclusivamente para o ambiente prisional, que iluminam a realidade verificada no campo pesquisado. 


\subsubsection{A educação fora da escola}

Na obra "Educação formal e não formal", Jaume Trilla $(2009$, p. 8) inicia seu artigo, "A educação não formal” citando Montesquieu em “O Espírito das Leis” (1973, p. 61) ${ }^{19}$, que afirma: "recebemos três educações diferentes ou contrárias: a de nossos pais, a de nossos mestres, e a da sociedade."

Dessa forma, Trilla recorre a Montesquieu para introduzir a ideia de classificação dos “tipos" de educação existentes Assinala que se o autor vivesse atualmente, certamente acrescentaria um quarto tipo de educação: a não formal "um tipo de educación que no proviene de la família, ni consiste em esta influencia tan difusa como potente que se produce cuando el individuo se relaciona directamente con "el mundo", ni tampoco es la que se recibe en el sistema escolar propriamente dicho" (2009, p. 8-9).

Depois de ressaltar o caráter histórico da instituição escola - o que é essencial a toda sociedade é a educação, e a escola foi e é historicamente constituída e organizada para fins específicos, sendo insuficiente para todos os objetivos educativos -, situa a formulação da ideia de educação não formal na segunda metade do século $\mathrm{XX}$, no período pós-guerra, impulsionada por uma série de fatores sociais, econômicos e tecnológicos.

Entre tais fatores estavam: a necessidade de incorporação de setores sociais tradicionalmente excluídos dos sistemas educativos; transformações no mundo do trabalho, que obrigam novas formas de capacitação profissional; ampliação do tempo livre; sensibilidade social crescente sobre a necessidade de implementar ações educativas para setores da população em conflito, socioeconomicamente marginalizados. Para Trilla (2009, p. 11), duas vertentes ideológicas fundamentaram a formulações sobre a educação não formal: de um lado, a aspiração de fazer avançar a justiça social e o Estado de Bem-Estar e, de outro, a busca funcional de mecanismos de controle social.

Gohn (2008) atribui a ampliação do conceito de educação de maneira a incorporar práticas educativas desenvolvidas fora da instituição escola, aos desafios gerados pela globalização - da economia, mas também no âmbito da cultura - e pelos avanços tecnológicos da era da informação, no entanto, ressalta o papel do agente executor das atividades: as organizações da sociedade civil.

Ela [a educação não formal] aborda processos educativos que ocorrem fora das escolas, em processos organizativos da sociedade civil, ao redor de ações coletivas do chamado terceiro setor da sociedade, abrangendo movimentos sociais,

\footnotetext{
${ }^{19}$ MONTESQUIEU. O espírito das leis. Livro Quatro, Cap. IV. In.: Os Pensadores. Abril Cultural. 1973. 569p.
} 
organização não governamentais e outras entidades sem fins lucrativos que atuam na área social; ou processos educacionais, frutos da articulação das escolas com a comunidade educativa, via conselhos, colegiado etc. (GOHN, 2008, p. 7).

A autora destaca duas outras importantes consequências da globalização, que se refletem sobremaneira nas práticas não formais de educação. A primeira delas é a transformação da área da cultura "no conflito social central" do período: "A cultura se transformou no mais importante espaço de resistência e luta social”, afirma (GOHN, 2008, p.9).

A outra consequência da globalização, relacionada à primeira, é a "metamorfose do sistema de desigualdade social no capitalismo para um sistema de exclusão social" (2008, p.11). De acordo com a autora, nesse período, as lutas sociais serão para a inclusão de setores da população anteriormente excluídos por desigualdades socioeconômicas, e agora “também excluídos por desigualdades socioculturais (dadas pelo sistema educacional, pela raça, etnia, sexo etc.)" (2008, p.12).

Nesse contexto, o alargamento da noção de educação para além da escola é orientado pela perspectiva da inclusão social, e as iniciativas de promoção dessa inclusão por meio de atividades vinculadas ao campo da cultura, ganham destaque no rol das ações empreendidas por organizações da sociedade civil.

Considerar as atividades não formais de educação como meio de inclusão social é uma ideia presente nas reflexões de vários autores. No entanto, Trilla, em entrevista a Varón e Ubal (2009, p. 82) destaca que o conceito de educação não formal é descritivo, pertencendo ao conjunto de conceitos que pretendem simplesmente nomear uma parte da realidade, sem juízo de valor, recurso utilizado para organizar teoricamente um determinado campo de análise. O que significa que nem toda atividade de educação não formal destina-se à inclusão social.

Para o autor (2009, p. 82-98), esse é um conceito absolutamente insuficiente para orientar ações educativas, sejam públicas - formulação de políticas - ou privadas - realização de atividades diversas. A concretização de práticas educativas sejam formais, não formais ou informais, prescindem da qualificação da ação, ou atribuição de valor. Daí, são necessários conceitos denominados valorativos, ou ideológicos, que estabeleçam os objetivos da educação e a quem se destina. 


\subsubsection{Inclusão}

No campo das atividades educativas não formais, há diferentes conceitos para práticas educativas destinadas à inclusão social, ou à promoção de direitos, destacando-se o campo dos Direitos Humanos (educação em e para os direitos humanos), o da Formação para o Trabalho, o do Desenvolvimento Humano, da Educação Popular (HADDAD, 2009, p. 5), além da educação continuada e educação ao longo da vida.

É fato que práticas de educação não formal com vistas à inserção social ou promoção de direitos tem sido amplamente difundidas, inclusive por ações de governos, na educação de crianças, adolescentes e jovens pobres (LARANJEIRA E TEIXEIRA, 2008 e PATTO, 2007).

Haddad (2009), destaca que pessoas jovens e adultas em situação de vulnerabilidade social constituíram-se, historicamente, como público prioritário para as ações de educação não formal destinadas à inclusão social. Citando Beisiegel (2004), afirma que as referências mais remotas são da ação da Unesco, no período imediatamente posterior à Segunda Guerra Mundial, em estimular campanhas de alfabetização de adultos, como forma de estimular o desenvolvimento aos países pobres.

Posteriormente, a Unesco difundiria a ideia de Educação Permanente e, na sequência, já nos anos 1990, a noção de Educação ao Longo da Vida. Para Haddad, os conceitos de educação formulados pelo organismo internacional nominam práticas educativas orientadas para adaptar os indivíduos à sociedade.

Em sentido contrário, o conceito de educação popular, originário das reflexões de Paulo Freire, traz consigo a ideia de transformação social por meio da emancipação e da mobilização por direitos (FREIRE, 1996). Confirmando as ponderações de Gohn (2008) em relação à centralidade do campo da cultura nos conflitos sociais contemporâneos, Haddad (2009) avalia que a educação popular vem incorporando novas dimensões da vida social, para além das desigualdades socioeconômicas, notadamente os aspectos culturais e os desafios colocados às sociedades dos países da América Latina neste período de ordem democrática, mas marcados pela manutenção das desigualdades.

Como apontado anteriormente, Claude (2005) aproxima a noção de educação para os direitos humanos do conceito de educação popular. Em consonância a esta proposição, Padilha (2005) lembra que, em toda a sua obra, Paulo Freire não fez referência a tratados ou declarações de direitos humanos, mas afirmou que "uma das primordiais tarefas da pedagogia 
crítica radical libertadora é trabalhar a legitimidade do sonho ético-político da superação da realidade injusta" $\left(2000^{20}\right.$, p. 43 apud PADILHA, 2005, p. 170).

Embora seja explícita essa proximidade de objetivos, educação popular e educação para/em direitos humanos guardam uma diferença entre si, em relação ao público ao qual se destinam e aos agentes promotores. A primeira, é desenvolvida com pessoas jovens e adultas pobres e é promovida por movimentos sociais e organizações da sociedade civil que têm sua missão orientada para a promoção da cidadania (GOHN, 2008), fora dos muros da escola.

Já a educação para/em direitos humanos pode orientar práticas não formais de educação, mas também vem sendo exercitada no ambiente escolar, portanto, envolvem crianças e adolescentes, além dos profissionais da educação (SCHILLING, 2005; CARVALHO, 2005, VARGAS, 1998, entre outros), e na formação de diferentes agentes públicos, como apontam os programas de direitos humanos apresentados anteriormente. Também se diferenciam entre si, em razão do papel do Estado na sua realização - no caso da educação em/para os direitos humanos, organismos governamentais atuam na formulação e execução de diferentes ações, havendo, inclusive, a institucionalidade conferida pela elaboração do Plano Nacional de Educação em Direitos Humanos, de responsabilidade da Secretaria Especial de Direitos Humanos da Presidência da República.

Também pode se verificar a relação entre as noções de educação, educação em/para direitos humanos e a de desenvolvimento humano:

Los conceptos de desarrollo humano y de derechos humanos comparten una subyacente perspectiva universalista del ser humanos como un agente; [...] Esta perspectiva conduce a la pregunta de cuáles serían las condiciones, capacidades y/o derechos básicos que normalmente permiten a un individuo funcionar como un agente. (O’DONNELL ${ }^{21}$, mimeo s/d apud HADDAD, 2009, p. 7).

Ainda entre os conceitos ideológicos (TRILLA, 2009) que qualificam o termo educação, e interessam particularmente à compreensão das atividades educativas desenvolvidas na prisão, encontra-se a educação social. A obra Pedagogia Social (SOUZA NETO; SILVA E MORA, 2009) data o surgimento do termo em 1949, quando a Seção Cultural do Alto Comissariado da República Francesa na Alemanha organizou um encontro internacional para discutir "os problemas da instrução dos jovens inadaptados". O objetivo era discutir como educar as crianças órfãs da guerra. Em 1951, criada a Associação Internacional

\footnotetext{
${ }^{20}$ FREIRE, Paulo. Pedagogia da indignação: cartas pedagógicas e outros escritos. São Paulo, Editora UNESP, 2000 .

${ }^{21}$ O’DONNELL, Guillermo. Democracia, Desarrollo Humano y Derechos Humanos (versión revisada de la ponencia presentada en el taller desarrollado en Heredia, Costa Rica, 1 y 2 de feb de 2002) mimeo.
} 
de Educadores de Jovens Inadaptados, hoje renomeada Asociación Internacional de Educadores Sociais (AIEJI).

Otto (2009, p. 32) afirma que a educação social resulta das duas tradições alemãs no campo da assistência social. A primeira, baseada no conceito de bem-estar, e a outra, que se orienta pela combinação de práticas de assistência com educação. Em decorrência dessa dupla influência, o autor conclui que a Pedagogia Social busca aliviar a exclusão social por meio da promoção do "funcionamento social da pessoa", que articula diferentes dimensões, como a inclusão, a participação, a identidade e a competência social como membros da sociedade.

No Brasil, o debate sobre o conceito da Pedagogia Social, bem como seus desdobramentos para as atividades de ensino e pesquisa são recentes, conforme Silva et al. (2009, p. 289); e os autores apontam como áreas prioritárias para atuação da Pedagogia Social: infância e adolescência, juventude, ONGs e terceiro setor, além do sistema penitenciário. Sobre esse último, os autores, afirmam "que não se devem conceber métodos e técnicas específicas para a Educação de presos, sob pena de submetê-los a uma dupla estigmatização", e deslocam a especificidade para a formação dos educadores que atuarão nas prisões.

\footnotetext{
Ainda que se possa afirmar que a condição de confinamento prolongado, a necessidade de rápida adaptação a um ambiente hostil marcado pela cultura da violência e a perda de referenciais de valor sejam capazes de suscitar outras formas de saberes e de produção de conhecimentos, a questão fundamental é a qualidade da formação de quem faz a mediação entre os objetivos da Educação e os objetivos da pena e da prisão, e é esta a tarefa que se quer seja assumida pela Pedagogia Social. (SILVA et. al, 2009, p. 299).
}

Alguns autores apontam uma polêmica entre os conceitos de educação não formal e educação social, ou a ciência que a estuda: a Pedagogia Social. No texto de introdução da obra "Pedagogia Social" (2009, p. 11), os organizadores da obra afirmam terem adotado a postura de "recusar o termo educação não formal enquanto categoria classificatória, contestar o caráter não científico atribuído a ela e resgatar a historicidade de suas práticas".

De outro lado, Trilla (2009 apud VARÓN; UBAL, 2009) afirma não conseguir identificar o campo específico de atuação da educação social, exceto pela dimensão do trabalho exclusivo com sujeitos em situação de conflito ou risco social.

No entanto, os âmbitos de atuação da Pedagogia Social envolvem setores tão amplos que é difícil delimitar qual é o público destinatário das práticas de Educação Social. Para Caliman (2009, p. 59), por exemplo, os possíveis âmbitos de atuação seriam: “a educação de adultos, educação de adolescentes em situação de risco, a recuperação e reinserção social de 
sujeitos toxicodependentes, a orientação escolar de alunos atingidos por fortes condicionamentos sociais (pobreza, exclusão social, desagregação familiar), a ação educativa dentro dos ambientes familiares, a influência dos meios de comunicação social e das associações e grupos juvenis (grupo de pares, gangues etc.)”.

Ryynänen, (2009, p. 69), ao relatar as práticas da Pedagogia Social no contexto finlandês, elenca entre os públicos atendidos: "os trabalhos ligados às questões de juventude, terceira idade, imigrantes, usuários de álcool e drogas, reabilitação, novos desafios do mundo do trabalho, comunidades (sub)urbanas e rurais etc.".

Outra divergência no âmbito da classificação das práticas educativas está relacionada às noções de escolar e não escolar, utilizadas em substituição aos conceitos de educação formal, não formal e informal, conforme explica Haddad (2009, p. 3):

\begin{abstract}
A imagem do iceberg tem sido utilizada com frequência para fazer a distinção entre educação escolar e não escolar. A parte visível do iceberg seria a educação escolar, aquela que se confunde com o próprio termo educação e que é valorizada socialmente como um direito humano e fator de conquista de cidadania. A parte submersa, com um volume maior e sustentação da parte visível, normalmente não reconhecida pelo senso comum, aqui denominamos de educação não escolar. Um trata de todo processo educativo institucionalizado, graduado em séries, hierarquizado. Outro, que ocorre fora deste marco oficial, pode ter como características, desde práticas formalmente organizadas e sistemáticas até processos informais de ensino e aprendizagem. A somatória do escolar com o não escolar constituiria o universo da educação. (HADDAD, 2009, p. 3).
\end{abstract}

Sem desconsiderar a relevância das diferentes formas de classificação das atividades educativas, para efeito de análise do material identificado no percurso desta pesquisa, será adotada a formulação sobre educação não formal proposta por Trilla (2009), citada anteriormente e detalhada a seguir. A busca da compreensão das atividades identificadas não será baseada em conceitos predefinidos, mas naquilo que elas produzem de singular na relação com o ambiente prisional.

\title{
1.3.3 Campos de atuação
}

Trilla (2009) define educação escolar - ou formal - com base em algumas características: forma coletiva de ensino e aprendizagem; acontece num espaço próprio; possui tempo prefixado (horário, calendário letivo); separação institucional de dois grupos assimétricos e complementares (alunos e professores); conteúdos trocados entre professores e alunos é ordenado e classificado em um plano de estudo; a aprendizagem é descontextualizada. 
Educação não formal, de acordo com este critério "metodológico", seria aquela que se dá mediante procedimentos ou instâncias que rompem com uma ou mais dessas características.

Outra possibilidade de classificação - a estrutural -, não se baseia no caráter escolar ou não escolar da atividade, mas, sim, na sua inclusão ou exclusão do sistema oficial de ensino, portanto, a distinção entre uma e outra forma de educação é administrativa, legal, do ponto de vista do direito formal.

O formal é definido, em cada país e em cada momento, por leis e outras disposições administrativas; o não formal, por sua vez, é o que está à margem do organograma do sistema educativo graduado e hierarquizado resultante. (TRILLA, 2009, p. 23).

E Trilla (2009, p. 24) define educação não formal como "o conjunto de atividades, meios e instituições específica e diferenciadamente desenhados em função de explícitos objetivos de formação ou de instrução, que não estão diretamente dirigidos à provisão dos graus (níveis ou modalidades) próprios do sistema educativo regular”.

Da mesma forma, aponta que existem possibilidades - instituições, atividades, meios e programas - de educação não formal em todos os setores. Cita, como exemplo, um conjunto de áreas nas quais se encontra a gênese da educação não formal, ao menos no que se refere à sua identificação como tal. São eles: mundo do trabalho, ócio e cultura; a própria escola e "educação social".

De maneira complementar, Gohn (2008, p. 98-99) relaciona seis áreas de atuação para a educação não formal: 1) aprendizagem política de direitos de cidadania; 2) capacitação para o trabalho; 3) aprendizagem e exercício de práticas de organização comunitária; 4) aprendizagem dos conteúdos da educação formal em formas e espaços diferenciados; 5) educação desenvolvida na e pela mídia; 6) educação para a arte do bem viver, que reúne conjunto de aprendizagens para conviver com stress e a ansiedade provocados pelo cotidiano da vida.

O campo pesquisado permitiu identificar ações que podem ser inscritas em uma ou mais das áreas assinaladas.

No campo da capacitação profissional, registra-se a prevalência de atividades manuais, que podem ser consideradas "treinamento" (MANNHEIM, 1962) por não envolverem desafios criativos, remetendo à ideia da divisão do trabalho social, que exige "diversidade pedagógica" a fim de preparar diferentes grupos para o exercício de diferentes profissões (DURKHEIM, 1972, p. 39). Nesse grupo, as diferentes fontes pesquisadas identificaram 
atividades de formação básica em serviços da construção civil, como pedreiro e eletricista, panificação, além de um curso de injeção eletrônica, organizado e financiado por um voluntário da religião espírita.

Há ainda as atividades que se inserem no campo das práticas culturais, como o curso de música ministrado por uma voluntária da Igreja Batista, identificada na pesquisa de campo; e outras vinculadas às ações de comunicação e novas tecnologias da informação, como as oficinas de rádio e os cursos de informática, também em curso nas unidades prisionais pesquisadas. .

Também foram identificadas atividades orientadas para a promoção dos direitos das pessoas encarceradas, por meio de reflexões e discussões compartilhadas com pessoas "de fora" do mundo das prisões, como é o caso do projeto "Quem Somos Nós”, do "Grupo de Diálogo entre Universidade Comunidade e Cárcere" (GDUCC) e do projeto "Promotoras Legais Populares".

Muñoz (2009, p. 7), após a produção do Informe sobre educação das prisões no mundo, identificou três modelos:

el modelo "médico", "de deficiencia cognitiva" y "oportunista". En pocas palabras, el modelo médico tiende a tratar principalmente lo que se percibe como deficiencias psicológicas del delincuente; el modelo de deficiencia cognitiva se centra en la promoción del desarrollo moral y el modelo oportunista en la vinculación del aprendizaje a la formación para el empleo. (MUÑOZ, 2009, p. 7).

A identificação desses modelos, que traduzem as diferentes concepções sobre a população carcerária - pessoas que precisam de tratamento médico-psiquiatríco; indivíduos deficitários em termos de conhecimentos morais e técnicos; mão de obra desqualificada para o mercado de trabalho -, parece ser similar à encontrada no sistema penitenciário brasileiro, mas é interessante que o relator não tenha identificado iniciativas destinadas à promoção de direitos, pelo menos não significativas a ponto de considerar este também um grupo, ou modelo, específico.

Uma hipótese para esta ausência em âmbito mundial é a singularidade do processo de constituição das organizações da sociedade civil brasileira (COSTA, 2002; DAGNINO, 2002; GOHN, 2008), promotoras das atividades de educação em direitos humanos e para o exercício da cidadania no ambiente prisional.

Costa (2002), Dagnino (2002) e Gohn (2008) apontam a mobilização contra a Ditadura Militar e, posteriormente, pelo alargamento dos direitos de cidadania como as principais ações em torno das quais se constituíram as chamadas organizações da sociedade 
civil, sobretudo na década de 1980. Gohn (2008) constata que os anos de 1990 trouxeram uma nova configuração para o campo, com a proliferação de organizações dedicadas a atuar na economia informal ou como empresas terceirizadas pelos governos para a execução precária de ações públicas. Ainda, assim, conforme a autora, persiste a atuação daquelas que ela denomina "ONGs cidadãs", que têm como missão a ampliação do acesso aos direitos de cidadania e elegem a formação de grupos excluídos desses direitos como estratégia de intervenção na esfera pública, conforme será demonstrado no Capítulo 4 deste trabalho.

\subsubsection{Tensão entre $o$ formal e 0 não formal}

Por fim, há as práticas de incentivo à leitura, como o projeto "Leitura Livre" e aquelas destinadas à elevação da escolaridade, que ocorrem em paralelo ao sistema formal de ensino e, por isto, aqui consideradas também educação não formal. É o caso da preparação dos estudantes para participarem dos exames de certificação e das ações de alfabetização, mesmo quando propostas e coordenadas por agências estatais.

A condição de não formalidade de tais práticas reforçam a relatividade histórica e a política do conceito de educação não formal. Em consonância a esta ideia, Machado (2009, p. 141), afirma que a educação a distância e a educação de jovens e adultos em diferentes países são exemplos dessa relatividade. Ainda sobre o tema, Trilla (2009apud VARÓN; UBAL, 2009) afirma que a participação em exames de certificação envolve a educação não formal o processo de preparação, que pode se dar em grupo ou individualmente, com ou sem a orientação de um educador -, mas também a formal, tendo em vista que os exames estão inscritos nas normas que regulam os sistemas educacionais.

Essa é a condição verificada nas unidades prisionais do Estado de São Paulo que têm as atividades de educação subordinadas à Funap, como aquelas onde se desenvolveu a pesquisa de campo. Embora as ações de preparação para os exames estejam integradas ao campo da educação não formal, portanto, objeto de análise dessa pesquisa, as atividades desenvolvidas pela Funap não foram incluídas por tratar-se de um órgão vinculado à Secretaria de Administração Penitenciária (SAP), portanto, um agente do Estado, e a este estudo interessa investigar a atuação da sociedade civil nas prisões.

No entanto, a existência de um órgão estatal, que promove atividades de elevação de escolaridade não formais, utilizando a mão de obra carcerária por meio da figura do monitor 
preso, tem proporcionado um interessante debate nacional entre profissionais da área da educação, que atuam em prisões, mas também pesquisadores, e os da área da segurança.

As discussões têm ocorrido no âmbito do processo de elaboração das Diretrizes Nacionais para a Educação nas Prisões, estimulado pelos Ministérios da Educação e da Justiça, a partir de 2005, por meio do projeto Educando para a Liberdade ${ }^{22}$.

O acompanhamento dos debates, que resultaram no texto base para a formulação de Diretrizes Nacionais para a Educação nas Prisões $^{23}$, e também o posicionamento público de representantes da Funap demonstram uma nítida cisão entre os posicionamentos das equipes vinculadas aos órgãos gestores da educação e aqueles destinados à administração penitenciária.

Há, por parte dos gestores da administração penitenciária, e a Funap/SP representa este setor, predileção pelas práticas não formais de educação destinadas à elevação da escolaridade, enquanto os gestores da educação buscam a vinculação à educação formal. $\mathrm{O}$ texto base (UNESCO, 2006) ${ }^{24}$ para formulação das Diretrizes demonstra esta tensão, sendo impreciso quanto à forma de educação a ser adotada. O documento não vincula a educação no sistema penitenciário à modalidade "Educação de Jovens e Adultos", embora indique que a parceria entre os órgãos gestores da educação e da administração penitenciária deva possibilitar a "disponibilização do material pedagógico da modalidade de EJA para as Escolas que atuam no Sistema Penitenciário, como insumo para a elaboração de projetos pedagógicos adequados ao público em questão". (2006, p. 36).

Quanto aos educadores, o texto afirma que "preferencialmente" devem pertencer aos quadros das Secretarias de Educação e, ao relacionar orientações para a formação e valorização dos profissionais envolvidos na oferta, admite que pessoas presas atuem como monitoras "do processo educativo". Este foi um dos pontos de maior tensão na elaboração do texto, pois os gestores da educação consideram a presença da monitoria de pessoas presas uma forma de barateamento da oferta e entrave para a garantia da qualidade da educação ofertada. Defendem que deve ser preservado o direito à educação formal, tal qual é ofertada fora das prisões.

A Funap/SP, por sua vez, defende a atuação dos monitores sentenciados, classifica esta possibilidade como "educação entre pares", um preceito da "Educação Popular" e, ao

\footnotetext{
${ }^{22}$ Ver mais detalhes sobre o projeto no Capítulo 2.

${ }^{23}$ Seminário Nacional pela Educação nas Prisões, organizado por MEC, MJ e Unesco, e realizado entre os dias 12 e 14 de julho de 2006.

${ }^{24} \mathrm{O}$ referido texto, em fevereiro de 2010, momento da redação final deste trabalho, encontrava-se em discussão no Conselho Nacional de Educação para a formulação das Diretrizes Nacionais para a Educação nas Prisões. O CNE informou que a finalização do trabalho era prevista para março de 2010.
} 
mesmo tempo, parte do processo educativo dos próprios monitores. O tema é bastante complexo e envolve diversos argumentos (GRACIANO, 2005; CARREIRA, 2009). Nesta pesquisa, nos interessou que a opção por este modelo de educação, incluindo a atuação de monitores presos, em substituição aos profissionais habilitados em acordo com as normas educacionais do País, reforça a ideia do ambiente prisional como campo privilegiado da atuação das práticas não formais de ensino e, ao menos no Estado de São Paulo, em substituição à educação formal.

Ao refletir sobre este risco, Trilla (2009) destaca que a substituição do formal pelo não formal é estimulada por questões econômicas. Lembra que não existem estudos sobre os custos ou investimentos na educação não formal, mas que as características dessas iniciativas estimulam seu barateamento em relação à formal. Entre essas características, a participação de educadores leigos em atividades que se aproximam muito das escolares; a curta duração das atividades; e a focalização em pequenos grupos, prescindindo da necessidade de universalidade, existente na educação formal.

No mesmo sentido, Núñez (2009, p. 241-256), refletindo sobre as possibilidades e limites da educação inserida no campo não formal, alerta para o risco de as ações empreendidas serem tomadas como formas de controle social "neohigienistas" sobre as populações indesejadas. Assim, a educação deixaria de cumprir sua missão de "antidestino", ao possibilitar o acesso universal à produção cultural e científica acumulada pela humanidade, para transformar-se em formas de "gestão diferenciada", em geral precarizadas, para grupos de risco social.

\subsubsection{Educação X Segurança}

As práticas não formais de educação como mecanismo de controle serão objeto de reflexão no Capítulo 3 deste trabalho. Neste momento, no entanto, cabe ressaltar que o debate descrito anteriormente, fortemente estimulado pelos gestores do sistema prisional paulista, para além das considerações do campo educacional, sintetizadas na tensão existente na substituição das práticas formais pelas não formais, pode ser interpretado também à luz das características que conformam o ambiente prisional na atualidade, descritas no início deste capítulo.

Dessa perspectiva de análise, a disputa não recairia sobre a educação formal e não formal, mas sobre a partilha do poder na gestão das penas, uma vez que uma das “assistências" previstas na Lei de Execução Penal (LEP, 1984) seria de responsabilidade de 
um agente interno ao governo, mas externo ao sistema prisional. Haveria, neste caso, um desequilíbrio na ordem interna, atualmente estabelecida sobre as relações os dois grupos permanentes na prisão: os funcionários da segurança e a população carcerária.

Durante o seminário "A educação como direito humano: a escola na prisão" 25 , professoras/es de redes públicas de ensino que atuam em prisões narraram as difículdades encontradas para o exercício da profíssão na prisão, sobretudo por conflitos com as equipes da segurança. As situações se assemelham àquelas encontradas pelos educadores das organizações: são histórias de imposição de empecilhos ao processo educativo, sempre sob a alegação das razões de segurança.

A diferença é que, no caso das professoras das redes públicas, a administração dos conflitos, por mais desgastante que seja pessoalmente, não é feita diretamente entre elas e a equipe de segurança, mas entre os gestores das duas pastas. Também não se trata da atuação isolada de um indivíduo, facilmente removível caso contrarie "regras de segurança", mas de uma equipe permanente - se um professor for removido, de acordo com a legislação educacional, outro terá de substituí-lo.

Nesse caso, a presença contínua de atores alheios à prisão, respaldados pelo próprio Estado, seria mais um elemento a ser gerido para a manutenção da ordem interna.

\subsubsection{Educação informal e os elementos da prisão pós-disciplinar}

A ideia da repartição da educação em diferentes tipos também está presente em Mannheim (1962, p. 42), que propõe a distinção entre os aspectos formais, institucionalizados da educação, e a noção mais ampla e generalizada: "decorrente da influência da sociedade educativa, onde educamos pelo emprego de influências comunitárias."

No mesmo sentido, Trilla (2009) defende que a educação se organiza em dois campos: o primeiro, constituído pela educação informal; e um segundo, constituído pela educação formal e não formal.

Esta consideração é particularmente interessante para analisar o ambiente prisional, e não apenas a escola ou as atividades educativas na prisão. $O$ autor não distingue os dois campos pela presença ou ausência de intencionalidade nos processos desenvolvidos em um ou outro. Ao contrário, afirma que as ações educativas informais têm tanta intencionalidade

\footnotetext{
${ }^{25}$ Atividade realizada em janeiro de 2009, durante o Fórum Social Mundial, em Belém (PA), por iniciativa de organizações da sociedade civil - Ver mais detalhes no Capítulo 4.
} 
quanto as formais ou não formais. Também refuta a ideia sobre o caráter sistemático das ações empreendidas neste segundo grupo, em oposição à educação informal.

Para Trilla (2009, p. 13), a distinção está nos critérios de diferenciação e especificidade da função do processo educativo:

[...] estaríamos ante um caso de educação informal quando o processo educativo acontece indiferenciada e subordinadamente a outros processos sociais, quando aquele está inserido inseparavelmente em outras realidades culturais, quando não emerge como algo distinto e predominante no curso geral da ação em que transcorre tal processo, quando é imanente a outro "cometido", quando precisa de um contorno nítido, quando tem lugar de maneira difusa.

Na prisão, pode-se entender como processos informais de educação os dispositivos disciplinares utilizados. Um exemplo é a postura que as e os internas/os devem assumir diante de agentes penitenciários e mesmo de outras pessoas, não presas, que frequentam o ambiente prisional - mãos atrás das costas, cabeça baixa.

Da mesma forma, a demora em liberar estudantes dos pavilhões para a ida à escola, motivo de tensão e desgaste entre estudantes e agentes penitenciários, a suspensão das atividades escolares sem motivo explicito e alheia à vontade da equipe pedagógica, a não distribuição de cadernos, mesmo quando disponíveis (GRACIANO, 2005).

Todas estas são práticas comuns ao ambiente prisional, conforme constataram pesquisas acadêmicas e outros documentos (UNESCO, 2008; CARREIRA, 2009). Não há dúvidas que há intencionalidade educativa nelas, conforme diversos autores que estudaram a prisão, destacadamente, as considerações de Foucault (1987) em Vigiar e Punir, sobre o adestramento de corpos e mentes ${ }^{26}$. Schilling (1991, p. 46), ao refletir sobre os exemplos de ações que descrevem a concretização da educação informal promovida em prisões por meio das normas disciplinares impostas pelos funcionários responsáveis pela manutenção da ordem, sintetiza: "Na situação extrema, a necessidade de estabelecer um novo sistema de valores, atitudes e forma de vida é vital e dessa capacidade resultará o êxito em salvaguardar a própria vida (e a de outros)."

Ocorre que são práticas que se realizam de forma difusa, que ganham sentido justamente porque se entrecruzam, se interpõem a outras práticas. Não há cursos ou palestras para transmitir o ensinamento implícito na possibilidade de não liberar estudantes para a escola. O educativo, neste caso, é justamente o jogo do exercício do poder, a incerteza das

${ }^{26}$ Cf.: SALLA, 2006; SCHILLING, 1991; BETTELHEIM,1989; LEVI,1988. 
regras - nunca se sabe ao certo o que vai acontecer, mas seja lá o que for, o que se espera é um comportamento disciplinado, contido - educado, talvez?

De acordo com as conversas informais não registradas e as entrevistas realizadas no processo na pesquisa de campo, a relação entre as e os internos também é marcada por práticas de educação informal. As regras de conduta que devem ser incorporadas e exercitadas (JOCENIR, 2001; MENDES, 2001 e 2005), os códigos de linguagem e comunicação estabelecidos (BARBATO JR, 2006 e GRACIANO, 2005), e, mais recentemente, os valores disseminados por grupos organizados no interior da prisão, que transpõem os muros e afetam a sociedade em geral (ADORNO; SALLA, 2007), são práticas contidas no universo da educação informal.

Entre os códigos de linguagem e comunicação, destaca-se o desenvolvimento de vocabulário específico e atribuição de significados às tatuagens, feitas algumas vezes de forma espontânea e outras, por meio da violência, quando as imagens são usadas para designar transgressão às normas de conduta do mundo do crime, ou condição subalterna (BARBATO JR, 2006, p. 137-156). Ainda neste campo, Graciano (2005, p. 115) cita o "abano" como

\footnotetext{
forma de comunicação à distância, por gestos, em que os braços são movimentados e cada abaixar de mão corresponde a uma letra do alfabeto; a letra que se quer usar para formar a palavra desejada é marcada por um movimento mais brusco, para baixo. É como "soletrar no ar", mas para "chegar" à letra desejada é preciso percorrer o alfabeto abanando as mãos. A técnica pode parecer cansativa - para cada letra, inúmeros abanos, até serem formadas frases -, mas as mulheres garantem que é extremamente eficiente.
}

Sobre o código de conduta, relata Jocenir, no seu "Diário de um detento: o livro" (2001, p. 85): "Nos dias seguintes tudo transcorreu dentro da maior normalidade [...] Procurava conhecer bem as normas do presídio a fim de não as transgredir. Prestava muita atenção às normas de conduta dos detentos".

Já os valores formulados e impostos por grupos organizados guardam a especificidade de interferir inclusive na vida externa à prisão. Refletindo sobre a onda de violência ocorrida em São Paulo em 2006, atribuída a um dos grupos organizados que atua no sistema prisional paulista, o Primeiro Comando da Capital - PCC, Adorno e Salla (2007, p. 17) afirmam: “Trata-se de uma organização impregnada de rígidos valores. Ao mesmo tempo que prega a solidariedade e proclama luta contra as injustiças, prevê aplicação de pena de morte sem apelação ou julgamento". Analisando o suposto Estatuto da organização, divulgado pela imprensa em 2006, os autores constatam a interferência do grupo na vida de detentos e ex- 
detentos, além de seus familiares, seja pela cobrança de contribuições - regra que, se quebrada, pode custar a vida -, ou pelo sistema de apoio que inclui a contratação de advogados e ajuda às famílias.

Duas das pessoas entrevistadas durante o processo de pesquisa fizeram referência às regras das organizações em relação às práticas educativas. Ambas afirmaram que o grupo Comando Revolucionário Brasileiro da Capital (CRBC) tem orientação bastante favorável ao desenvolvimento de atividades por pessoas "de fora", garantindo as condições para a realização dos trabalhos. Já o PCC teria posição mais reticente em relação à permanência de pessoas "de fora" no ambiente prisional, incluindo educadores. Entretanto, a organização permite que monitores sentenciados atuem, possibilitando a preparação dos alunos para participarem dos exames de certificação.

Embora não tenha sido objeto desta pesquisa a análise de tais práticas, essas considerações são necessárias para a compreensão das relações estabelecidas entre as dimensões formais, não formais e informais da educação nas prisões.

As informações obtidas no campo pesquisado, interpretadas à luz das considerações de Chantraine (2006) sobre os novos arranjos relacionais entre funcionários das prisões e grupos organizados de presos, sugerem que, no atual contexto das prisões, além das restrições normativas, políticas e materiais, a efetivação da educação formal e não formal enfrenta ainda as regras impostas pelas práticas informais de educação, ou, dos grupos que lideram a organização interna dos estabelecimentos.

\subsection{Algumas conclusões}

\subsubsection{A prisão no Brasil}

A situação do sistema carcerário brasileiro guarda semelhanças com as características que diferentes autores vêm identificando como traços comuns às políticas de encarceramento em diversos países, notadamente a partir da segunda metade da década de 1970.

As condições históricas e culturais do Brasil não permitem as noções de Estado penal (WACQUANT, 2002), prisão pós-disciplinar (CHANTRAINE, 2006) e fim do ideal de reabilitação (GARLAND, 2008) sejam integralmente adotadas como categorias de análise para o contexto prisional brasileiro. No entanto, é inegável que alguns traços desses conceitos 
podem ser verificados na realidade brasileira, conforme indicam as informações referentes ao perfil da população carcerária e às suas condições de encarceramento, incluindo a superlotação das unidades, a garantia das assistências previstas na Lei de Execução Penal, e o acesso ao trabalho.

Entre as características compartilhadas com outros países estão: a ampliação do encarceramento com o recrutamento de pessoas que passaram por sucessivos processos de exclusão, tais como renda, educação, acesso ao mercado de trabalho e, destacadamente, pertencimento a grupos étnico-raciais historicamente marginalizados - no caso brasileiro, a população negra.

A superpopulação, como consequência, e a privatização do sistema carcerário, como solução à ampliação do encarceramento, surgem como faces distintas de um mercado lucrativo, que ganha projeção nos Estados Unidos.

Por fim, as novas configurações do sistema prisional estimulam a constituição de novos arranjos das relações internas, em que ganha destaque a relação estabelecida entre funcionários e grupos organizados de presos, sedimentada sob sistemas de privilégios e gerenciamento de riscos, corridos e provocados por ambas as partes.

As assistências e o acesso ao trabalho integram o funcionamento desse sistema de privilégios, conforme será demonstrado no Capítulo 3 deste trabalho.

\subsubsection{A educação nas prisões, segundo as normas}

A educação em geral, a educação de jovens e adultos particularmente, e a educação nas prisões especificamente, são direitos consagrados em diferentes normas, nacionais e internacionais.

De maneira geral, a redação desses documentos é imprecisa quanto à afirmação do dever do Estado em garantir a educação formal. Muitos documentos apontam a partilha da responsabilidade entre Estado e sociedade civil na oferta da educação nas prisões, sem distinguir entre a educação formal e a não formal.

Também, múltiplos são os significados do termo educação nas leis e outros instrumentos normativos, porque são variados também os objetivos que ela deve assumir no cárcere. De maneira geral, a educação surge ora como a garantia de um direito humano, destinada à satisfação de uma necessidade humana, ora aparece como possibilidade de formação moral, capaz de incutir em indivíduos desviados virtudes morais que eles não 
aprenderam até este momento de sua vida. Há também a perspectiva de formação para o mercado de trabalho e a intenção de proporcionar o desenvolvimento integral das pessoas, com a expectativa que elas possam conduzir suas vidas de forma autônoma.

Ainda que possam ser apontadas imprecisões nos documentos, todos eles afirmam que atividades de educação - formal ou não formal - são partes constituintes e essenciais à execução da pena.

Ocorre que nenhuma das normas estabelece prazos para que os Estados as implementem. Também não prevêem mecanismos de monitoramento da sua concretização. Dessa forma, e os dados do sistema carcerário confirmam, as normas tornaram-se "letra morta”. Chantraine (2006) explica: a prisão se adaptou às leis; não há contestação sobre seu conteúdo, e seu cumprimento foi absorvido pela estrutura de organização do cárcere.

\subsubsection{A educação nas prisões - algumas possibilidades de análise}

O ambiente prisional comporta diferentes maneiras de realização de atividades educativas, abarcando a educação formal, a educação não formal e a educação informal.

Há, em relação à educação não formal, um intenso debate conceitual, sobre sua função, que se estabelece em torno do público ao qual ela se destina. Muitos autores consideram que esta é uma forma de transmitir conhecimentos ou valores - de variadas espécies - a grupos que não tiveram acesso, ou foram expulsos, ou encontram dificuldade de adaptação à instituição social concebida para tal fim: a escola. Para alguns autores, a educação não formal seria então um mecanismo de incluir, ou adaptar, estas pessoas à sociedade, ainda que esta inclusão seja baseada na crítica à sua estrutura.

Há outras reflexões que consideram a educação não formal simplesmente as atividades educativas - de inúmeros tipos - que não estão inscritas nas leis que regulam a educação dos países. A qualificação dessas práticas, do ponto de vista ideológico, é atribuída pelos atores nelas envolvidos. Para os fins desta pesquisa esta é a conceituação adotada, e a análise das práticas identificadas será efetuada no Capítulo 3 deste trabalho.

A aplicação do conceito à realidade verificada revelou que não existe educação formal no sistema educacional paulista, a não ser nas unidades onde as direções contrariam as orientações da SAP e buscam parcerias com os órgãos de governo responsáveis pela gestão da educação pública, ao invés de aceitar a atuação da Funap, fundação vinculada à SAP, responsável pela promoção da educação nas prisões do Estado. 
A opção do governo é manter, mesmo as atividades destinadas à elevação da escolaridade, apartada do sistema público de ensino, e privada da atuação de profissionais habilitados, substituídos pelos próprios presos.

O que parece ser uma tensão ideológica entre as práticas formais e não formais é, à luz das considerações de Chantraine (2006), um arranjo destinado a manter o equilíbrio da ordem interna às prisões, baseada nas relações estabelecidas entre funcionários e presos, onde não há lugar para outros atores, sobretudo quando estes são também representantes do Estado - as equipes pedagógicas das secretarias de educação.

No caso do sistema prisional do Estado de São Paulo, há, nitidamente, uma opção pelas práticas não formais de educação, que pode se justificar por diversas razões, entre elas, os baixos custos e a falta de institucionalidade, ao mesmo tempo em que permite demonstrar que leis são cumpridas, e as pessoas estão estudando nas prisões.

Ao lado, acima e abaixo das práticas não formais, verifica-se a singularidade da educação informal que marca as instituições prisionais. São as regras disciplinares, impostas pelas equipes de segurança, mas também os códigos de conduta e ética disseminados entre a população carcerária. A denominada "cultura da prisão" não é uma novidade - livros biográficos de egressos, reportagens, pesquisas e outras fontes trazem para fora dos muros as regras de convivência internas.

O que chamou a atenção nesta pesquisa, no entanto, é o fato de as práticas educativas do campo não formal e formal estarem submetidas à educação informal. Grupos organizados de presos, com a devida complacência dos agentes do Estado, permitem, ou não, a realização de atividades educativas. Mais um sintoma da prisão pós-disciplinar em terras brasileiras. 


\title{
CAPÍTULO 2 - EDUCAÇÃO NÃO FORMAL NAS PRISÕES - A CONSTRUÇÃO DE UM CENÁRIO
}

\author{
O supletivo ginasial era à noite. À noite não me \\ deixavam sair porque minha pena se aproximava \\ de cem anos. A diretoria não permitia por \\ questão de segurança. Também, a lógica deles \\ era assim: para que estudar se vai ficar preso a \\ vida toda? Decerto deve estar com algum plano \\ de fuga ou coisa assim. Sem chances. \\ (MENDES, 2001, p. 454).
}

Chantraine e Mary (2006) afirmam que a observação e a contextualização das mudanças e adaptações sofridas pelas prisões nas sociedades ocidentais contemporâneas se constituem por intermédio da articulação de três níveis da realidade: o carcerário, o penal e o social.

Outros autores apontam a relação entre o comportamento da população em geral frente à população carcerária, ou indivíduos delinquentes, e as políticas penitenciárias formatadas e implantadas. Garland (2008), entre outros, demonstra que os políticos em geral - em funções executivas ou legislativas; de "direita" ou de "esquerda", são movidos pela opinião pública nas suas proposições de tratamento ao crime e aos criminosos. A opinião pública, por sua vez, é influenciada pela mídia, que produz informação privilegiando os interesses de seus leitores - classes médias e grupos privados.

Dessa forma, para compreender a inserção do tema da educação nas prisões em geral, e da educação não formal em particular, na dimensão social da realidade, este capítulo apresenta dados e informações sobre a atuação dos governos - das esferas nacional e estadual paulista - e da mídia sobre estes temas.

A impossibilidade de acessar informações abrangentes diretamente dos órgãos responsáveis pela realização das ações de educação e pela execução da pena determinou a adoção de diferentes estratégias para a obtenção dos dados. Pesquisas a páginas eletrônicas, busca de informações por meio de redes de organizações de direitos humanos e educação, além de entrevistas com organizações e profissionais que atuam no sistema prisional fizeram parte da construção deste quadro.

Já a cobertura do tema pela mídia foi verificada com base no serviço de clipping "Resumo da Mídia", que acompanha 75 jornais de todos os Estados. Foram identificados textos no período de 2002 a 2008, com base no cruzamento das palavras: educação, escola, prisão, penitenciária. 
Para atender aos objetivos desta pesquisa, as informações e dados apresentados serão articulados em torno de dois eixos: as ações no campo da educação nas prisões - destacando a inserção das práticas não formais - e a atuação de organizações da sociedade civil e pessoas voluntárias na sua realização.

\subsection{A ação do governo federal}

\subsubsection{O Ministério da Justiça}

Os convênios celebrados pelo Ministério da Justiça com organizações da sociedade civil foram identificados por meio da página eletrônica do órgão e do Portal da Transparência, organizado pela Controladoria Geral da União (CGU). Por este Portal, foram identificados todos os convênios estabelecidos pelo Ministério da Justiça no Estado de São Paulo, com organizações da sociedade civil, universidades, órgãos do governo estadual, prefeituras e instituições do sistema de justiça.

Consideramos os convênios que tiveram o último repasse de recursos entre 2002 e aqueles em vigência até 20 de novembro de 2009, data da última visita feita ao Portal da Transparência para efeito deste trabalho.

Tabela 17 - Convênios Ministério da Justiça (2002 a 2009)

\begin{tabular}{|l|l|l|}
\hline Convenente & Número de Convênios & $\mathbf{\%}$ \\
\hline Prefeituras & 169 & $45,3 \%$ \\
\hline Governos de Estados (diversos órgãos) & 113 & $30,4 \%$ \\
\hline Ministério Público & 1 & $0,3 \%$ \\
\hline Defensoria Pública & 7 & $1,9 \%$ \\
\hline Tribunal de Justiça & 1 & $0,3 \%$ \\
\hline Conselho Comunitário (Campinas) & 1 & $0,3 \%$ \\
\hline USP & 2 & $0,6 \%$ \\
\hline CIEE & 47 & $12,6 \%$ \\
\hline Outras organizações & 31 & $8,3 \%$ \\
\hline Total & $\mathbf{3 7 2}$ & $\mathbf{1 0 0} \%$ \\
\hline
\end{tabular}

Disponível em: http://www.portaltransparencia.gov.br/convenios/ConveniosLista.asp?UF=SP\&Estado $=\mathrm{SAO}+\mathrm{PAULO} \&$ CodMunicipio $=\&$ CodOrgao $=30000 \&$ Orgao $=$ MINISTERIO + DA + JUSTICA $\&$ TipoConsulta $=1$ \&Periodo. Acesso em: 20 nov. 2009.

A descrição disponível no Portal da Transparência não permite apreender em detalhes o conteúdo dos projetos conveniados. A descrição divulgada possibilitou identificar apenas 
duas ações, desenvolvidas por organizações da sociedade civil e destinadas ao diretamente ao sistema prisional, e uma destinada a pessoas egressas ${ }^{27}$.

A primeira, realizada pela Associação de Apoio ao equilíbrio bio-psicossocial, denomina-se projeto "CRE-SER", de Bauru, e é descrita como realizadora de ações para "busca do equilíbrio psico-efetivo dos servidores das unidades prisionais" 28.

A outra iniciativa é denominada "Projeto Novo Sol" ${ }^{29}$, desenvolvido pela União Brasiliense de Educação e Cultura no município de São Carlos, e a descrição informa tratar-se da concessão de bolsas de estudos a 28 pessoas privadas de liberdade, mas não há informações sobre a etapa ou modalidade ensino em questão nem o tipo de curso.

Há ainda uma ação específica de apoio a pessoas egressas do sistema prisional, desenvolvida pelo Conselho Comunitário de Campinas $^{30}$.

Os demais convênios firmados abrangem temas diversos, com destaque para a área dos direitos do consumidor, ou consumo consciente; projetos de preservação ambiental; promoção de direitos de populações indígenas e pessoas com deficiência; apoio às famílias de refugiados, restauração de biblioteca do Museu de Arte Sacra; pesquisa sobre penas alternativas e organização e monitoramento da $1^{\text {a }}$ Conferência Nacional de Segurança Pública $^{31}$.

Os dois convênios firmados com a Universidade de São Paulo tratavam, respectivamente, de estímulo à produção de conhecimento e informação sobre a lei de falências e pesquisas no campo da preservação ambiental. ${ }^{32}$

\footnotetext{
${ }^{27}$ Os convênios firmados com órgão de governos e do sistema de Justiça não serão descritos por não fazerem parte do foco de pesquisa deste trabalho; mas a título de informação, registra-se que versavam sobre a construção de unidades prisionais; material de apoio para a constituição e fortalecimento de guardas municipais; cursos de capacitação em cidadania para jovens e crianças em situação de risco; capacitação de lideranças comunitárias femininas, no âmbito do Pronasci (Mulheres da Paz), entre outros.

28 Disponível em: <http://www.portaltransparencia.gov.br/convenios/DetalhaConvenio.asp? Cod Convenio $=515516 \&$ TipoConsulta=1>. Acesso em: 19 nov. 2009.

29 Disponível em: <http://www.portaltransparencia.gov.br/convenios/DetalhaConvenio.asp?CodConvenio = 539242\& TipoConsulta=1>. Acesso em: 19 nov. 2009.

30 Disponível em: <http://www.portaltransparencia.gov.br/convenios/DetalhaConvenio.asp?CodConvenio = 487088\&TipoConsulta=1>. Acesso em: 19 nov. 2009.

${ }^{31}$ As instituições conveniadas - algumas com mais de um projeto -, são: Sociedade Humana Despertar (SHD); Rede Nacional de pessoas vivendo com HIV/Aids; Instituto Brasileiro de Política e Direito do Consumidor; Instituto Socioambiental; Instituto Brasileiro de Defesa do Consumidor; Cáritas Diocesana de Bauru; Fundação de Proteção e Defesa do Consumidor; Associação de Pais e Amigos dos Excepcionais de Bauru; Cáritas Diocesana de São Paulo; Associação Amigos do Museu de Arte-Sacra; Instituto Latino-Americano das Nações Unidas para Prevenção do Delito e Tratamento do Delinquente (Ilanud); Via-Pública Instituto para o Desenvolvimento da Gestão; Rede Internacional em Defesa do Direito de Amamentar (IBFAN- Brasil); Fundação Nacional do Meio Ambiente Dr. Ernesto Pereira.

32 Disponíveis em: <http://www.portaltransparencia.gov.br/convenios/DetalhaConvenio.asp?CodConvenio = 499053\&TipoConsulta=1> e $\quad<\mathrm{http} / /$ www.portaltransparencia.gov.br/convenios/DetalhaConvenio.asp? CodConvenio $=517547 \&$ TipoConsulta $=1>$. Acesso em: 20 nov. 2009.
} 


\subsubsection{Estagiários no sistema prisional}

No conjunto das informações, impressiona o grande número de convênios estabelecidos com o Centro de Integração Empresa-Escola (CIEE) - 12,6\% do total, quando o conjunto de todas as outras organizações corresponde a 8,3\%. A descrição desses convênios tem basicamente a mesma redação: “Aceitação como estagiários de alunos regularmente matriculados e que venham frequentando efetivamente, cursos de educação superior e de ensino médio, de educação profissional de nível médio ou de educação especial", e alguns poucos especificam os órgãos para os quais os estagiários serão destinados.

A página eletrônica do CIEE define esta instituição como "instituição filantrópica mantida pelo empresariado nacional", cujo "maior objetivo nestes 45 anos de existência é encontrar, para os estudantes de nível médio, técnico e superior uma oportunidade de estágio que os auxiliem a colocar em prática tudo o que aprenderam na teoria"33.

Embora os convênios com o CIEE não citem explicitamente a atuação de estagiários no ambiente prisional, a página eletrônica do Ministério da Justiça disponibiliza o texto de um protocolo de intenções firmado entre o órgão e o CIEE, em 2007, que define como objeto

\footnotetext{
a conjugação de esforços entre as partes para a reintegração social das pessoas presas e egressas através de ações que promovam: o direito, a cidadania e a dignidade da pessoa humana; a iniciação e a qualificação profissional; a implementação de atividades produtivas; o desenvolvimento da cultura empreendedora; a integração familiar e comunitária; a cultura, a recreação e os esportes; a elevação da escolaridade e a educação continuada; a valorização e a capacitação dos profissionais do sistema penitenciário. (BRASIL, MINISTÉRIO DA JUSTIÇA b, 2007, p. 2) ${ }^{34}$.
}

O documento também afirma, na cláusula $5^{\mathrm{a}}$, que o termo não estabelece transferência de recursos entre as partes e que os escritórios estaduais do CIEE deveriam, em acordo com órgão responsável pela administração penitenciária local, elaborar projetos específicos, prevendo as ações específicas, com os valores necessários à sua realização e previsão orçamentária. Também determina que o financiamento dos projetos seja garantido com os recursos do Fundo Penitenciário Nacional (Funpen), disponibilizado pelo Departamento Penitenciário Nacional (Depen), por meio de convênios celebrados entre os escritórios locais

\footnotetext{
$33<$ http://www.ciee.org.br/portal/index.asp $>$.

${ }^{34}$ Ver: BRASIL, MINISTÉRIO DA JUSTIÇA (b). Protocolo de Intenções. 2007. Disponível em: <http:// http://portal.mj.gov.br/data/Pages/MJDA8C1EA2ITEMID8B687DE17F0D43C8B22BEE7558A78A89PTBRIE. htm>. Acesso em: 27 out. 2009.
} 
do CIEE e o Ministério da Justiça. Por fim, estabelecem que as ações desenvolvidas no âmbito destes convênios sejam denominadas "Novos Horizontes".

\subsubsection{Estagiários no sistema prisional paulista}

A fim de elucidar a natureza dos convênios identificados no Portal da Transparência, o CIEE foi procurado e revelou que tanto a Secretaria de Administração Penitenciária quanto a Funap beneficiam-se destes convênios estabelecidos com o Ministério da Justiça ${ }^{35}$. Nas duas instituições os estagiários atuam em diversas funções, inclusive em unidades prisionais.

Em relação à Funap, órgão responsável pelas atividades de educação e trabalho nas prisões paulistas, infelizmente a falta de informações não permite apreender qual é o papel dos estagiários nas unidades prisionais, e se atuam na realização de outras atividades de educação não formal, além da preparação dos educandos para os exames de certificação da educação básica ou capacitação de sentenciados para exercerem a função de monitoria nessas mesmas turmas. ${ }^{36}$

Quanto à Secretaria de Administração Penitenciária de São Paulo, identificamos ${ }^{37}$ o Decreto $n^{0} 54.341 / 2009$, que regula o estágio não remunerado nas unidades prisionais para estudantes de Direito, Psicologia, Serviço Social, Agronomia, Educação Física e Enfermagem $^{38}$. O texto não designa as atribuições, apenas indica que todos, exceto os estagiários de Agronomia, atuarão nas Diretorias de Reabilitação e nas Comissões Técnicas de Classificação. Os estudantes de Agronomia atuarão nas Diretorias de Qualificação Profissional e Produção Agroindustrial.

O objeto do protocolo de intenções entre Ministério da Justiça e CIEE é bastante amplo e recomenda que a instituição atue tanto na educação não formal - atividades culturais, lazer, esportes, empreendedorismo, profissionalização, entre outras - como na educação formal - elevação da escolaridade.

Faltam elementos para a compreensão de qual foi o alcance real do referido protocolo. Mas dada a natureza da atuação da instituição - seleção de estagiários -, é relevante pressupor

\footnotetext{
35 Informações obtidas por mensagem eletrônica de Glaucia Casalli M. Dias, responsável pelo setor "Atendimento a órgãos públicos, em 30/11/2009. A instituição comprometeu-se a fornecer a relação das atividades desenvolvidas pelos estudantes a serviço da Secretaria de Administração Penitenciária (SAP) e da Funap, mas não o fez.

${ }^{36}$ Ver: GRACIANO, 2005; CARREIRA, 2009.

${ }^{37}$ As informações relativas à SAP foram obtidas por meio de entrevista com Mauro Bittencourt, responsável pela Coordenadoria de Reintegração Social.

${ }^{38} \mathrm{O}$ texto altera o Decreto $\mathrm{n}^{\circ} 47.169 / 2002$, para incluir o estágio de enfermagem.
} 
que o Ministério da Justiça tinha expectativa que estudantes universitários, sob a denominação de estagiários, realizassem as atividades de educação formal e não formal.

Em relação à educação não formal, de maneira geral, é impossível qualquer consideração sem as informações sobre as atividades concretas. Como já exposto anteriormente, a educação não formal só ganha significado com a definição da natureza e da intencionalidade das ações, que variam muito.

Mas quanto às atividades com vistas à elevação da escolaridade, trata-se, nitidamente, da negação do direito ao desenvolvimento intelectual pela precarização das condições de ensino, destinando às unidades prisionais estudantes, portanto, pessoas sem a habilitação necessária prevista pela Lei de Diretrizes e Bases da Educação. São práticas desenvolvidas à margem do sistema de ensino oficial, o que significa dizer, excluída de todos os recursos materiais e humanos garantidos nas normas que regem a educação no País.

\subsubsection{ProJovem prisional}

O Programa Nacional de Inclusão de Jovens: Educação, Qualificação e Ação Comunitária (ProJovem) $^{39}$ foi implantado em 2005, com o objetivo de propiciar elevação da escolaridade para jovens que não concluíram a primeira etapa do ensino fundamental, qualificação profissional e estimular ações de planejamento e execução de ações comunitárias de interesse público. A responsabilidade de sua concretização está sob a coordenação da Secretaria-Geral da Presidência da República em parceria com o Ministério da Educação, o Ministério do Trabalho e Emprego e o Ministério do Desenvolvimento Social e Combate à Fome.

A gestão do programa é feita por meio de um Comitê Gestor, coordenado pela Secretaria-Geral da Presidência da República/Secretaria Nacional de Juventude e integrado pelo Ministério da Educação, Ministério do Trabalho e Emprego e Ministério do Desenvolvimento Social e Combate à Fome. Como suporte operacional, o Comitê conta com uma Comissão Técnica também composta por representantes da Secretaria-Geral e dos três ministérios parceiros.

Foram previstos mecanismos de controle e acompanhamento da implementação do programa por meio de um sistema próprio, denominado Sistema de Monitoramento e Avaliação (SMA). Organizado em quatro subsistemas, o SMA tem por atribuições: 1)

\footnotetext{
39 Informações disponíveis em: <http://www.projovemurbano.gov.br/site/interna.php?p=material\&tipo $=$ Noticias $\&$ cod $=718>-$ ProJovem urbano. Acesso em: 20 fev. 2010.
} 
monitorar cadastro e matrícula de alunos, e também a formação de educadores e coordenadores; 2) inspecionar as unidades de formação para assegurar a precisão das informações; 3) elaborar instrumentos de avaliação externa da formação dos educandos; 4) desenvolver ações de avaliação da implementação e efetividade do programa.

O projeto foi adaptado para atender grupos juvenis específicos - adolescentes, habitantes do meio urbano; do campo e trabalhadores. Em 2008, no âmbito do Pronasci, foi estendido aos jovens de 18 a 29 anos que se encontram em situação de privação de liberdade, e foram feitas adaptações na carga horária - as horas de atividades extraclasse foram suprimidas -, as atividades de inclusão digital sofreram a restrição do não acesso à internet; e as ações comunitárias devem ser pensadas no contexto presente, da prisão:

\begin{abstract}
Nas unidades prisionais, o exercício da cidadania, compreendido sob a ótica das formas de participação no meio social em que os jovens estão inseridos, significa colocar em foco os modos de sociabilidade e de pactuação em torno do que é de interesse coletivo, do bem comum. Por meio de uma metodologia participativa, a dimensão da "Participação Cidadã" tem a intencionalidade de interferir, interagir e, de alguma forma, contribuir para a convivência entre presos, presos e agentes prisionais, presos e suas famílias, estimulando a construção de experiências positivas que propiciem novos parâmetros para a convivência social, incidam na melhoria da qualidade de vida nas prisões e referenciem a construção de novas perspectivas de futuro para esses jovens. (SALGADO; AGUIAR, 2009, p. 24).
\end{abstract}

Outra adaptação feita foi a forma de pagamento da bolsa de $\mathrm{R} \$ 100,00$, destinada aos educandos, que na situação de privação de liberdade, não lhes é entregue diretamente, mas, sim, a algum familiar.

No caso do ProJovem-Prisional, o acesso ao programa depende da celebração de convênio entre o governo federal e os governos estaduais, responsáveis pela administração do sistema prisional. Nas demais versões, os convênios também podem ser celebrados com os governos municipais.

Em junho de 2008, foram celebrados convênios com os governos do Pará, Rio de Janeiro e Acre, para atender, respectivamente, 500, 200 e 60 jovens presos em cada um dos Estados; e a realização efetiva do projeto teve início por volta de abril de 2009, portanto, ainda não existem avaliações sobre o seu funcionamento. Os arcos ocupacionais escolhidos pelos Estados foram: agroextrativismo (Acre), Esporte e Lazer (Rio de Janeiro) e Madeira e Móveis (Pará).

O Estado de São Paulo não aderiu ao programa e, de acordo com $P$., uma das funcionárias da penitenciária Parada Neto entrevistadas no âmbito desta pesquisa, a Prefeitura 
de Guarulhos, município onde se localiza a unidade, demonstrou interesse em implantar o projeto, baseada no convênio municipal, mas a Funap não autorizou. $P$. explica que desde 2007, a Funap busca centralizar as atividades de educação e trabalho, limitando a autonomia das administrações das unidades:

\begin{abstract}
Nós ficamos na dependência da Funap de aceitar ou não determinados trabalhos. Todas as parcerias, obrigatoriamente, têm que passar pela Funap. Esses dias, eu tentei entrar em contato com um local que estava para trazer um grupo profissionalizante e, de imediato, já foi barrado. A Funap alega que tem a pessoa específica que faz esse trabalho, que leva o projeto e coloca em prática, e isso acaba fechando um pouco o espaço da unidade prisional [...] Como a grade curricular e as condições do projeto, do ProJovem, não eram coniventes com a Funap, acabou não sendo aceito, não sendo colocado em prática. (P.).
\end{abstract}

As informações de $P$. parecem, num primeiro momento, contraditórias às análises produzidas por diversos autores, que apontam a histórica autonomia das direções das unidades para decidir sobre todos os assuntos relativos ao cotidiano prisional.

No entanto, impedir a realização de atividades para elevação da escolaridade, formação profissional e também de acesso a um pequeno auxílio financeiro, e não disponibilizar nada no lugar ${ }^{40}$ é bastante coerente com uma das características da prisão na atualidade: o fim do ideal de reabilitação. A oferta de atividades, quaisquer que sejam elas, não são prioridade. $\mathrm{O}$ que importa é que os arranjos relacionais internos à unidade sejam eficazes na garantia da ordem.

Esta é uma possibilidade de análise. A outra hipótese, é que isso acontece em razão das divergências partidárias entre governos federal e estadual, ou PT e PSDB. Esta é uma hipótese bastante plausível, se for considerado que o governo estadual paulista tem demonstrado resistência em aderir às iniciativas do governo federal. No campo educacional, apenas para citar um exemplo, São Paulo foi o último Estado a aderir ao Plano de Desenvolvimento da Educação (PDE), que começou a ser implementado em todo o País em 2007, e chegou ao Estado quase um ano depois.

\title{
2.1.1.4 Outros convênios
}

Paralelamente às informações sobre os convênios, disponibilizadas pela Controladoria Geral da União, por meio do Portal da Transparência, a página eletrônica do Ministério da Justiça

\footnotetext{
${ }^{40}$ Ver, no Capítulo 3, depoimentos e dados sobre a falta de oportunidades de atividades educativas nessa unidade.
} 
apresenta uma planilha, denominada "Convênios em andamento" ${ }^{41}$, que traz as informações sintetizadas na tabela a seguir.

Tabela 18 - Convênios em andamento - Departamento Penitenciário (MJ)

\begin{tabular}{|l|l|l|l|l|}
\hline Convenente & 2004 & 2005 & 2006 & Total \\
\hline Governos de Estados (diferentes órgãos) & & 12 & 32 & $\mathbf{4 4}$ \\
\hline Defensoria Pública & & & 1 & $\mathbf{1}$ \\
\hline Universidades & 2 & & 2 & $\mathbf{4}$ \\
\hline Creche Amadeu Barros Leal (CE) & & & 1 & $\mathbf{1}$ \\
\hline SENAC (MA) & & & 1 & $\mathbf{1}$ \\
\hline SENAI (DF) & & & 1 & $\mathbf{1}$ \\
\hline CIEE/SC & & 1 & $\mathbf{1}$ \\
\hline Associação Alfabetização Solidária (SP) & & & 1 & $\mathbf{1}$ \\
\hline Total & $\mathbf{2}$ & $\mathbf{1 2}$ & $\mathbf{4 0}$ & $\mathbf{5 4}$ \\
\hline
\end{tabular}

Fonte:< http://www.mj.gov.br/data/Pages/MJF3DBC1CEITEMID4934D0C1C6854826BAFC896832 C1D84FPTBRIE.htm>.

O convênio com a creche Amadeu Barros é denominado projeto "Brinquedoteca: a arte de brincar", destinado ao atendimento de cem crianças, filhos e filhas de mulheres presas; e o convênio com a Associação Alfabetização Solidária é referente à realização de concurso de produção literária em 499 unidades prisionais, sendo 173 presídios. Interessante notar que nenhum dos dois convênios foi identificado entre aqueles disponibilizados pela CGU, o que revela descompasso entre as informações.

A tabela a seguir sistematiza a distribuição dos convênios entre 23 Estados da Federação.

Tabela 19 - Número de convênios firmados pelo Depen,
por Estado da Federação (2004-2006)

\begin{tabular}{|l|l|}
\hline Estado & Número de Convênios \\
\hline Alagoas & 3 \\
\hline Amazonas & 2 \\
\hline Amapá & 1 \\
\hline Bahia & 1 \\
\hline Ceará & 3 \\
\hline Distrito Federal & 1 \\
\hline Espírito Santo & 2 \\
\hline Goiás & 4 \\
\hline Maranhão & 4 \\
\hline Minas Gerais & 1 \\
\hline Mato Grosso do Sul & 2 \\
\hline Mato Grosso & 5 \\
\hline
\end{tabular}

\begin{tabular}{|l|l|}
\hline Estado & Número de Convênios \\
\hline Paraíba & 2 \\
\hline Pernambuco & 2 \\
\hline Piauí & 1 \\
\hline Paraná & 2 \\
\hline Rio de Janeiro & 1 \\
\hline Rio Grande do Norte & 4 \\
\hline Rondônia & 6 \\
\hline Rio Grande do Sul & 1 \\
\hline Santa Catarina & 1 \\
\hline Sergipe & 2 \\
\hline São Paulo & 3 \\
\hline Total & $\mathbf{5 4}$ \\
\hline
\end{tabular}

Fonte: $<$ http://www.mj.gov.br/data/Pages/MJF3DBC1CEITEMID4934D0C1C6854826BA FC896832C1D84FPTBRIE.htm>

\footnotetext{
${ }^{41}$ Ver Anexos.
} 


\subsubsection{O Sistema " $S$ "}

A página eletrônica do Ministério da Justiça apresenta ainda um segundo protocolo de intenções, também de 2007, firmado com as instituições que compõem o chamado "Sistema S": o Serviço Nacional de Aprendizagem Industrial (Senai); Serviço Social da Indústria (Sesi); Serviço Social do Comércio (Sesc); Serviço Nacional de Aprendizagem Comercial (Senac); Serviço Brasileiro de Apoio às Micro e Pequenas Empresas (Sebrae).

Este protocolo de intenções tem exatamente o mesmo conteúdo do anterior no que se refere a seu objeto, mas é destinado exclusivamente à população carcerária feminina, que representa cerca de 5\% do total das pessoas privadas de liberdade em todo o País.

O termo estabelece as atribuições de cada uma das instituições envolvidas ${ }^{42}$, e, a exemplo do documento anterior, determina que as representações locais elaborem projetos específicos em acordo com os órgãos responsáveis pela administração penitenciária dos Estados. A diferença, neste caso, para o financiamento das atividades por meio dos recursos do Fundo Nacional Penitenciário, é que devem ser celebrados convênios entre o Ministério da Justiça e o órgão gestor do governo estadual.

Não foi identificado nenhum convênio entre o governo do Estado de São Paulo e o Ministério da Justiça com o Sistema "S" entre os dados disponibilizados no Portal da Transparência. Nas entrevistas realizadas com técnicos da Funap e da Secretaria de Administração Penitenciária (SAP), ambos citaram a celebração de um convênio com o Senai, por meio do Ministério da Justiça, mas não fizeram referência ao atendimento exclusivo a unidades femininas, ao contrário, o exemplo foi o curso de formação de mão de obra para construção civil (pedreiro).

Assim como os convênios com o CIEE, o protocolo de intenções com o Sistema "S" traz à tona a delicadeza das realizações que envolvem a transferência de recursos públicos para o setor privado, em qualquer área da administração pública.

Em se tratando do sistema prisional, a situação é ainda mais delicada, pois informações são mantidas em segredo por princípio (FOUCAULT, 1987); sua gênese é marcada pelas relações privadas entre carcereiros e prisioneiros, em que os primeiros extorquiam dinheiro dos segundos a título de pagamento dos serviços (RUSCHE; KIRCHHEIMER, 2004 p. 95); e o desenrolar de sua história vem sendo marcado pela corrupção na sua gestão (FOUCAULT, 2006; MENDES, 2001E 2005, ADORNO, 2001).

\footnotetext{
${ }^{42}$ Ver: BRASIL, MINISTÉRIO DA JUSTIÇA, 2007. Disponível em: http://portal.mj.gov.br/data/Pages/ MJDA8C1EA2ITEMID8B687DE17F0D43C8B22BEE7558A78A89PTBRIE.htm. Acesso em: 20 out. 2009.
} 
Para completar, diferentemente de outras áreas da gestão pública, o sistema prisional não tem mecanismos de controle social, assim como não há registro da atuação de organizações da sociedade civil no monitoramento das políticas penitenciárias, sobretudo no que se refere à execução orçamentária.

Também há no protocolo a nítida transferência da responsabilidade pela educação formal do Estado para a iniciativa privada, ao atribuir ao Sesi a responsabilidade pela realização de programas de elevação da escolaridade e educação continuada, na Cláusula Segunda - das Atribuições, item II.

Contudo, o protocolo traz alguns elementos inovadores, que incidem sobre a realidade do cárcere. O primeiro deles é a determinação para que o Senai proceda à pesquisa sobre o mercado de trabalho (Cláusula Segunda, item I) e que o Senac organize cursos de capacitação profissional de acordo com a demanda identificada, com estrutura curricular e carga horária compatível com o perfil profissional definido.

A proposição contraria o atual cenário verificado tanto nas unidades femininas quanto nas masculinas, em que os cursos denominados profissionalizantes, em sua maioria, são caracterizados por atividades manuais, socialmente desqualificadas ${ }^{43}$, utilizadas apenas para a ocupação do tempo livre (FOUCAULT, 1987, p. 216).

Outro aspecto a destacar é a previsão da extensão das atividades de educação, saúde preventiva da mulher, esporte, cultura e lazer também para os profissionais que atuam no sistema penitenciário. Todas as pessoas que atuam no desenvolvimento de ações educativas no cárcere entrevistadas para este trabalho, assim como as observações de campo realizadas apontam que parte da resistência de agentes de segurança em colaborar com as atividades é o sentimento de injustiça, ou ciúme, por considerarem que as pessoas presas - delinquentes têm acesso a bens - cursos, palestras, oficinas - que elas, sendo gente de bem, trabalhadora e honesta, não têm.

\footnotetext{
${ }^{43}$ Ver: AÇÃO EDUCATIVA e outros. Encontro Regional da América Latina de Educação em Prisões, 27 e 28/Mar/2008, Brasília. Informe preliminar sobre Educação de Mulheres Encarceradas. Disponível em: $<$ http://www.acaoeducativa.org.br/portal/index.php?option=com_content\&task $=$ view\&id $=1216>$. Acesso em: 12 fev. 2009 e Relatório sobre Mulheres Encarceradas, apresentado à Comissão Interamericana de Direitos Humanos em fevereiro de 2007, elaborado por: Centro pela Justiça e pelo Direito Internacional(Cejil); Associação Juízes para a Democracia (AJD); Instituto Terra, Trabalho e Cidadania (ITCC); Pastoral Carcerária Nacional; Instituto de Defesa do Direito de Defesa (IDDD); Centro Dandara de Promotoras Legais Populares. Associação Brasileira de Defesa da Mulher, da Infância e da Juventude; Asbrad; Comissão Teotônio Vilela (CTV); Instituto Brasileiro de Ciências Criminais (IBCCrim); com o apoio do Comitê Latino-Americano e do Caribe para a Defesa dos Direitos da Mulher (Cladem) e do Programa para a América Latina da International Women's Health Coalition. Disponível em: http://www.ajd.org.br/documentos_ver.php?idConteudo=4. Acesso em: 30 nov. 2009.
} 
Rusche e Kirchheimer (2004) verificaram haver, ao longo de toda a história da prisão, certo consenso social em torno da ideia de que as condições de vida das pessoas encarceradas deveriam ser um tanto piores do que aquelas experimentadas pelas pessoas livres, que vivem nas condições mais vulneráveis. É o "princípio de lesser eligiblity, segundo o qual a condição do detento deve ser inferior à do mais desfavorecido assalariado" (WACQUANT, 2002, p.36).

Esta proposição auxilia a explicar o sentimento de injustiça que os profissionais do sistema carcerário experimentam em relação à garantia de direitos - quaisquer que sejam - às pessoas presas, por também não terem acesso a direitos.

Garland (2008), ao relacionar a consolidação do Estado de Bem-Estar Social na Inglaterra - e seu correlato norte-americano, New Deal -, no período do pós-guerra até meados a década de 1960, assinala que o cenário de pleno emprego, garantia de políticas de saúde e educação, e redução das desigualdades, estimularam a solidariedade, fazendo com que, por exemplo, a criminalidade fosse interpretada como um problema social, que deveria ser tratado por profissionalmente por especialistas do campo social.

\footnotetext{
Neste contexto histórico, o crime podia ser visto não como uma ameaça à ordem social, mas como uma relíquia renitente de privações passadas. As agências penaisprevidenciárias podiam contribuir para aliviar este problema, através da ajuda e do tratamento aos desafortunados indivíduos e às famílias problemáticas, que foram deixados para trás pela maré de prosperidade e de progresso social. (GARLAND, 2008, p. 123).
}

Consequentemente, o declínio do Estado de Bem-Estar, marcado pelo desemprego e restrições às políticas sociais, combinados, no campo da cultura política, com a valorização de temas como a tradição, a ordem, hierarquia e autoridade, resultou "numa disciplina renovada e na intensificação de controles, direcionados, porém, primordialmente aos pobres e às comunidades marginalizadas [...]" (GARLAND, 2008, p. 217).

Nesse contexto, as justificativas sociais para a criminalidade foram desqualificadas porque "negavam a responsabilidade individual, exculpavam as falhas morais, mitigavam as punições, encorajavam o mau comportamento [...]” (2008, p. 220).

O Brasil não viveu nenhum período similar ao Estado de Bem-Estar Social; ao contrário, historicamente as desigualdades determinam as relações sociais e o acesso a direitos é restrito a segmentos da população, enquanto a maioria vive condição de privação aos bens econômicos, sociais, culturais e ambientais. 
A reflexão de Garland (2008) de que o cenário de restrições a direitos limita a possibilidade do exercício da solidariedade para com todos os grupos sociais ajuda a compreender a indignação dos trabalhadores do sistema penitenciário, e talvez da sociedade em geral, em relação às atividades socioeducativas e culturais destinadas às pessoas presas. Impera no Brasil, desde sempre, o que Garland (2008, p. 221) denomina "visão reacionária", em que "o problema subjacente da ordem era visto não como um problema durkheimiano de solidariedade, mas como um problema hobbesiano de ordem, cuja solução deveria ser uma versão centralizadora e disciplinar do Estado-Leviatã".

Daí, as ações de envolvimento dos profissionais do sistema em atividades visam a reverter uma situação amplamente diagnosticada, mas seus resultados efetivos são uma interessante incógnita. A educadora responsável por uma das ações analisadas neste trabalho salientou que a proposta inicial do projeto era que o grupo fosse constituído por presos e profissionais do sistema, mas estes últimos se recusaram, afirmando que sua participação criaria uma situação de igualdade entre as partes, o resultaria na sua perda de autoridade no exercício do controle disciplinar.

\subsubsection{Cooperação técnica}

Por fim, foi ainda identificado, na página eletrônica do Ministério da Justiça, um Projeto de Cooperação Técnica Internacional entre a Organização dos Estados Ibero-Americanos para a Educação, a Ciência e a Cultura (OEI), intitulado "Fortalecimento e Consolidação dos Processos de Gestão e Pesquisa do Programa Nacional de Segurança Pública com Cidadania Pronasci, com vista à Ampliação de sua Capacidade Institucional na Execução de Ações Educativas e de Articulação entre Segurança Pública e Políticas Sociais Desenvolvidas pela União, Estados e Municípios.

A duração prevista é de quatro anos (2008 a 2011), o valor estimado é de R\$ 23.415.550,00, a serem cobertos com recursos do orçamento do Ministério da Justiça e seu conteúdo é assim resumido:

reúne atividades que estão associadas no sentido de fortalecer os processos de gestão e execução do Programa Nacional de Segurança Pública com Cidadania Pronasci no âmbito do Ministério da Justiça. Sua estrutura programática congrega ações de pesquisa para a formulação de diagnósticos sobre as condições socioculturais e educativas da população prisional, perfil dos professores e monitores e as condições de oferta da educação. A partir da identificação e análise 
da realidade de toda a população prisional, o Projeto prevê a concepção e organização de processos metodológicos de ensino-aprendizagem que sejam adequados às condições de seu público-alvo, além da edição e publicação de materiais instrucionais para o apoio educacional nas ações de alfabetização, preparação para o Enem e educação profissional de jovens e adultos - Proeja Prisional. Como complemento desse conjunto de atividades, o Projeto contém um amplo programa de formação de professores, monitores, supervisores e coordenadores que vão atuar no atendimento educacional da população prisional. (BRASIL; MINISTÉRIO DA JUSTIÇA, 2008, p. 1).

Considerando as recomendações metodológicas de Garland em relação às análises de eventos recentes (BRASIL; MINISTÉRIO DA JUSTIÇA, 2008, p. 70-71) e destacando que o referido projeto de cooperação está em pleno desenvolvimento, mesmo não sendo possível tecer qualquer comentário sobre seus resultados, algumas observações são necessárias porque repetem um padrão comum de tratamento da educação em prisões pelos gestores.

Não há dúvidas da relevância da produção de diagnóstico sobre as condições de socioculturais e educativas da população prisional. Como já apontado anteriormente, a escassez de informações impossibilita análises - e proposições - abrangentes, corroborando para a perpetuação das ações pontuais, particulares a cada unidade.

No entanto, é incompreensível a transferência de recursos para um organismo internacional executar esta tarefa, quando o governo dispõe de conceituadas agências de produção de dados, como o Instituto Brasileiro de Geografia e Estatística (IBGE), o Instituto de Pesquisas Econômicas Aplicadas (Ipea) e, de forma especial, o Instituto Nacional de Estudos e Pesquisas Educacionais (Inep).

É intrigante que as atribuições de elaboração da concepção e organização de processos metodológicos de ensino-aprendizagem, assim como a formação de educadores, sejam terceirizadas à revelia do Ministério da Educação, e do Conselho Nacional de Educação, órgãos responsáveis pela educação no País, portanto, inclusive no interior das prisões. Da mesma forma, que a produção de materiais "instrucionais" seja também elaborada de maneira paralela ao Programa Nacional do Livro Didático para a Alfabetização de Jovens e Adultos, destinado justamente a estimular a produção de materiais que atendam à especificidade do processo de ensino-aprendizagem de pessoas adultas com baixa escolaridade, que é o caso da população carcerária.

$\mathrm{O}$ anúncio do projeto revela a perspectiva fragmentada do governo federal em relação à educação nas prisões. Longe de ser a realização de um direito, assumida pelos órgãos responsáveis, formalmente constituídos para tal fim, é terceirizada, para ser executada à sombra, privadamente, distante inclusive dos mecanismos de financiamento previstos para garantir a educação básica e, consequentemente, de seus instrumentos de monitoramento. 
O projeto, também, parece reproduzir, no âmbito do governo federal, a disputa pelo controle das atividades educativas na prisão, protagonizada entre os profissionais da área da educação e da segurança tanto no ambiente prisional (GRACIANO, 2005; CARREIRA, 2009) quanto nos órgãos dos governos estaduais, como demonstram os desdobramentos do projeto Educando para a Liberdade, citados no capítulo anterior.

\subsubsection{O Ministério da Educação}

\subsubsection{Educando para a Liberdade}

A partir de 2005, por meio de uma parceria que envolveu o escritório nacional da Unesco, a Organização de Estados Ibero-Americanos e apoio do governo do Japão, o Ministério da Educação e o Ministério da Justiça desenvolveram o projeto "Educando para a Liberdade".

A iniciativa tinha como objetivo "propiciar um ambiente favorável ao desenvolvimento de atividades educativas no sistema penitenciário" (UNESCO, 2008, p.30). O desenvolvimento das ações compreendeu oficinas envolvendo gestores das pastas da educação e segurança pública de todos os Estados, e foram aportados recursos para a concretização de atividades nos Estados de Acre, Espírito Santo, Maranhão, Mato Groso do Sul, Pará e Pernambuco.

Embora tenha ocorrido um processo de avaliação sobre a implementação do projeto no período de 2005 a 2007, não há informações detalhadas sobre as atividades empreendidas. Existem referências gerais sobre cada um dos eixos estruturantes do projeto.

Sobre o eixo 1: "Gestão e articulação", Teles e Duarte (2008, p. 36) destacam o esforço inédito de busca de articulação entre os gestores das áreas da educação e segurança, com a criação de comitês para formulação de ações, estratégias e metodologias de implementação. Os autores afirmam que tais comitês "tiveram pouco êxito" e constatam que, na maioria dos casos, a gestão dos projetos ficou sob o gerenciamento das Secretarias de Educação, o que foi um fator de entrave para o seu desenvolvimento. Destacam que foi observado que nos Estados em que a iniciativa contou com o maior apoio do órgão responsável pela administração penitenciária, as metas foram cumpridas "com menor nível de dificuldade". 
Os dados da pesquisa de avaliação indicam a dificuldade de concretização do projeto. Ao final de dois anos, 43,9\% dos dirigentes das unidades prisionais dos estados envolvidos afirmaram não conhecer o projeto. Entre as 39 escolas visitadas, em 76,9\% foram identificados fatores que dificultam o funcionamento normal das atividades ali realizadas. Entre eles destacaram-se: dificuldades na condução dos presos; falta de material didático para as turmas, falta de respeito às regras internas de segurança, falta de recursos pedagógicos para os internos (ANDRIOLA, 2008, 48-49).

O eixo 2: "Formação de profissionais" tinha como meta formar 702 educadores e 1.850 funcionários do sistema penitenciário. Ao final, tinham sido formados 198 educadores e 671 funcionários, respectivamente, $28 \%$ e $36 \%$ do previsto.

Sobre o eixo 3: “aspectos pedagógicos", que tinha por objetivo estimular o desenvolvimento de propostas pedagógicas, informam Teles e Duarte (2008, p. 38) que "foi pouco privilegiado, não sendo capaz de provocar alterações referentes a aspectos relevantes na oferta da educação como: projetos político-pedagógicos, currículos e práticas educacionais".

Outra linha de ação do "Educando para a Liberdade" foi a promoção das oficinas regionais, citadas acima, processo que culminou com a realização, em julho de 2006, de um encontro nacional que definiu diretrizes para a educação nas prisões. Os eventos envolveram gestores das pastas da Educação e Segurança, e no encontro nacional foi finalizado um documento que reunia uma série de orientações para a concretização da educação nas unidades prisionais. Ao final da atividade, foi informado pelos representantes do governo federal que o documento seria encaminhado ao Conselho Nacional de Educação e ao Conselho Nacional de Política Criminal e Penitenciária, para serem adequados e aprovados como "Diretrizes Nacionais para a Educação nas Prisões". Em março de 2009, o documento foi aprovado no CNPCP e, em fevereiro de 2010, estava sendo submetido a discussões no Conselho Nacional de Educação.

$\mathrm{O}$ debate $^{44}$ travado durante a construção do documento explicitou algumas das polêmicas e impasses, observados no cotidiano das escolas nas prisões, em parte já expostas no capítulo anterior. A tensa convivência entre as diferentes perspectivas da educação e da segurança, ou contenção da população carcerária, que no dia a dia dos presídios se traduz pela constante suspensão das aulas em razão de revistas às celas ou supostas ameaças de rebeliões, restrições a títulos de livros e transferências de educandos de unidades, entre outras medidas,

\footnotetext{
${ }^{44}$ Referência às discussões feitas durante o "Seminário Nacional pela Educação nas Prisões", realizado entre 12 e 14 de julho de 2006, em Brasília.
} 
na formulação das diretrizes, pôde ser observada na discussão sobre a definição da responsabilidade sobre a gestão das atividades educacionais.

O texto base (UNESCO, 2006) propunha que a oferta da educação no sistema penitenciário fosse resultado de uma articulação entre o órgão responsável pela administração penitenciária e a Secretaria de Educação de cada Estado, cabendo a esta última a responsabilidade pela gestão e coordenação da oferta; gestores responsáveis pela administração das prisões reivindicaram alteração no texto, garantindo a partilha da responsabilidade entre as pastas também na gestão e coordenação da oferta.

Ao governo federal, por meio dos Ministérios da Educação e Justiça, coube a responsabilidade de fomentar e induzir políticas públicas de educação nas prisões, em parceria com os Estados e municípios - o que, se concretizado, seria uma profunda inovação, já que o MEC, historicamente, vem sendo totalmente omisso sobre o tema.

Entre dezenas de outras deliberações, foi reivindicada a inclusão do registro dos educandos em situação de privação de liberdade no Censo Escolar; e que os cursos de graduação em Pedagogia e demais Licenciaturas implementassem em seus currículos a formação profissional em EJA e, nesta modalidade, formação específica para educação na prisão. Outra demanda urgente foi a adequação do espaço prisional para abrigar escolas.

Esse conjunto de reivindicações, que deveria ter sido transformado em diretrizes nacionais, dialoga com alguns dos desafios colocados para o campo. A demanda pelo registro no Censo Escolar responderia à necessidade de informação sobre a real oferta de educação escolar no sistema prisional, inclusive para que a sociedade civil pudesse exercer controle sobre o cumprimento desta obrigação pelo Estado. Atualmente, isto só é possível nos casos em que as classes da prisão são vinculadas a escolas públicas e, ainda assim, os dados não são desagregados - isto é, do total de matrículas na EJA, não se sabe quantas são do sistema penitenciário.

O texto busca explicitamente orientar a educação formal no ambiente prisional, marcando a responsabilidade do Estado, por meio dos órgãos responsáveis pela educação e administração penitenciária, na sua oferta, mas afirma que a gestão deve se manter "aberta a parcerias com outras áreas de governo, universidades e organizações da sociedade civil, sob a orientação de Diretrizes Nacionais" (UNESCO, 2006, p. 36).

A histórica omissão do Estado em relação à educação nas prisões, mas também as dificuldades apontadas anteriormente para a concretização da primeira iniciativa do governo nacional neste campo reafirmam o caráter privado da gestão do espaço prisional, apontado por vários autores (SOARES; ILGENFRITZ, 2003; PORTUGUÊS, 2001; ADORNO, 1991). De 
acordo com estes autores, dirigentes, funcionários e presos compõem grupos que formam estruturas fechadas e autônomas em relação a diretrizes externas às unidades, que estabelecem suas próprias regras de funcionamento, boicotando o que lhes parecer contrário a sua ordem. No atual contexto, como já assinalado no capítulo anterior, não se trata de negar a educação nas prisões, mas de buscar formas de ofertá-las sem alterar as estruturas de poder já estabelecidas - as adaptações identificadas por Chantraine (2006).

Às ações exercidas arbitrariamente Foucault (1987) denomina suplemento disciplinar em relação ao jurídico, que para ele, são a conformação do que se conhece como "penitenciário" - ou seja, a arbitrariedade que marca as unidades não é uma falha na organização do sistema prisional; ao contrário, ela é que garante sua existência.

\subsubsection{Brasil Alfabetizado}

Lançado pelo governo federal em 2003, o Programa Brasil Alfabetizado tem por objetivo a alfabetização de jovens e adultos com 15 anos ou mais. Conforme as Resoluções $\mathrm{n}^{\mathrm{o}} 22$ (20/abr/2006) e no 31 (10/ago/2006), até 2008 o Programa funcionava por meio de parcerias estabelecidas com órgãos de governos estaduais, municipais ou do Distrito Federal, e também com entidades da sociedade civil e instituições de ensino superior.

As organizações da sociedade civil e instituições de ensino superior tinham os repasses financeiros assegurados por meio da celebração de convênios ou termo de parceria, além da aprovação dos planos pedagógicos e cadastro dos alfabetizadores e alfabetizandos.

A partir de 2007, foram introduzidas mudanças no programa Brasil Alfabetizado (Resolução $n^{\circ}$ 12, de 24/4/2007), no sentido de limitar a participação de organizações da sociedade civil. Para tanto, uma das exigências para a celebração de contratos com municípios era que $75 \%$ dos educadores fossem professores das redes públicas de ensino.

Ante a dificuldade dos entes federados em cumprir essa exigência, atualmente o texto de apresentação do programa, apresentado na página eletrônica do MEC, informa que "o quadro de alfabetizadores deve ser composto, preferencialmente, por professores da rede pública [...] mas qualquer cidadão, com nível médio completo, pode se tornar um alfabetizador do programa. Ele deve cadastrar-se junto à prefeitura ou secretaria estadual de educação onde receberá formação adequada". 
Nota-se que a figura das organizações da sociedade civil desapareceu. Além de basearse na premissa que a Educação é dever do Estado, o limite à participação de organizações da sociedade na execução do programa também está relacionado às denuncias de irregularidades na utilização dos recursos, amplamente divulgadas pela imprensa em 2007, conforme exposto adiante.

A inclusão de pessoas privadas de liberdade no programa Brasil Alfabetizado havia sido considerada uma prioridade de atuação a partir de 2006, estabelecida na Resolução 31/2006 (Item II, Art. $4^{\text {o }} ; \S 3^{\circ}$ ), que apontava como segmentos sociais específicos considerados para efeito de priorização na aprovação dos convênios: a) jovens de 15 a 29 anos não alfabetizados; b) populações indígenas, bilíngues, fronteiriças ou não; c) populações do campo - agricultores familiares, agricultores assalariados, trabalhadores rurais temporários, assentados, ribeirinhos, caiçaras e extrativistas; d) remanescentes de quilombos; e) pescadores artesanais e trabalhadores da pesca; f) pessoas com necessidades educacionais especiais associadas à deficiência; g) população carcerária e jovens em cumprimento de medidas socioeducativas.

De acordo com informações do Ministério da Educação, em 2006, 3.238 pessoas encarceradas estavam sendo atendidas pelo programa ${ }^{45}$. Apesar das insistentes solicitações feitas ao longo da produção desta pesquisa, o MEC não forneceu as informações referentes aos convênios estabelecidos com organizações da sociedade para a alfabetização de pessoas privadas de liberdade no período de 2003 a 2008.

Por meio do portal Transparência, no entanto, não foi possível identificar convênios específicos para a atuação de organizações sociais na alfabetização em unidades prisionais mesmo anteriores a 2007.

\subsection{Ações de governo em São Paulo}

A busca pelas informações oficiais sobre as atividades educativas empreendidas por organizações, universidades e pessoas voluntárias nas unidades prisionais de São Paulo incluíram entrevistas com a Coordenadoria de Reintegração Social e Cidadania da Secretaria de Administração Penitenciária (SAP) e Funap.

\footnotetext{
${ }^{45}$ Ministério da Educação. Disponível em: <http://www.mec.gov.br>. Acesso em: 27 set. 2006.
} 
A SAP, por meio de entrevista com o coordenador de Reintegração Social e Cidadania, Mauro Bittencourt, informou que a coordenação das atividades educativas é de responsabilidade da Funap, mas admitiu que muitas organizações e pessoas desenvolvem ações mediante consentimento das direções das unidades prisionais. Também, citou a atuação da Faculdade de Direito da Universidade de São Paulo, por meio da realização do projeto "Grupo de Diálogo Universidade, Cárcere e Comunidade" (GDUCC), uma das iniciativas identificadas também no trabalho de campo desta pesquisa.

Informou ainda que a Coordenadoria de Reintegração Social e Cidadania vem passando por mudanças internas e que está em curso um levantamento de todas as atividades tanto compreendidas como destinadas à reintegração das pessoas privadas de liberdade. $\mathrm{O}$ objetivo é sistematizar esta informação e, em diálogo com os profissionais das áreas de ressocialização e segurança, elaborar um documento que indique os procedimentos básicos para o desenvolvimento de ações e atividades que deverão ser comuns a todas as unidades, porque consideradas essenciais no processo de ressocialização. Este processo deveria ser finalizado em 2009, para começar a funcionar a partir de 2010.

A Funap, por meio de entrevista com José Leme, pesquisador e técnico da instituição, informou que não dispunha das informações sistematizadas, mas tentaria organizá-las para atender à solicitação desta pesquisa, o que não foi possível. Também reforçou que há atividades articuladas diretamente com as direções das unidades, sem o conhecimento da Funap, então, não existe a possibilidade de conhecer todas as ações desenvolvidas no sistema penitenciário do Estado de São Paulo, tampouco as organizações ou pessoas responsáveis.

Durante a entrevista, citou algumas iniciativas, como a instalação de salas de cursos a distância feita pela Fundação Roberto Marinho, que funcionaram entre 2001 e 2003, por meio de convênio com o Ministério da Justiça.

Destacou a atuação da Federação das Indústrias do Estado de São Paulo (Fiesp) na promoção do curso de pedreiro, que em 2008, formou seis turmas de 20 alunos cada, em Franco da Rocha. O objetivo era estimular que empreiteiras absorvessem a mão de obra qualificada, o que não aconteceu, frustrando as expectativas de organizadores e estudantes; e citou um curso de mecânica desenvolvido pelo Senai.

Listou outras organizações que já desenvolveram ações de educação nas prisões, como universidades públicas (Unicamp e USP/Ribeirão Preto) e privada (Unip), o Centro Paula Souza, órgão responsável pela educação profissionalizante no Estado de São Paulo, e Senac. E informou ainda que a própria Funap realizou oficinas de teatro. 
José Leme apontou a falta de financiamento como um dos principais limites à realização das ações de educação no sistema penitenciário paulista. Embora seja o órgão oficialmente responsável pela garantia de educação e trabalho nas prisões, a Funap não dispõe de orçamento próprio e seus recursos advêm da comercialização dos produtos feitos das pessoas encarceradas, sobretudo, da reforma de móveis. Também existe a possibilidade de repasses pontuais de recursos, feitos por outros órgãos da administração pública, quando desejam realizar ações específicas nas prisões.

Dessa forma, a atuação Funap fica condicionada, também, à celebração de parcerias com instituições que financiem as atividades, ou seja, financiadas por outros órgãos, como o Ministério da Justiça. Neste sentido, a Funap opera como uma organização de privada, ainda que de finalidade pública, que necessita buscar financiamento para atuar, assim como as ONGs.

Leme e Bittencourt, indagados sobre o papel das organizações da sociedade, responderam que é desejável que a sociedade partilhe responsabilidades com o poder público no que se refere à promoção da educação e trabalho nas prisões, inclusive o financiamento das ações.

A análise da natureza - e consequências - das diferentes formas de relação entre o Estado e organizações da sociedade civil será tratada nos próximos capítulos.

\subsection{A mídia e a educação de pessoas presas}

\subsubsection{Limites da análise}

Considerar a cobertura da imprensa como fonte de informação é um recurso de caráter bastante restrito. É sabido que a seleção de informações divulgadas nos veículos de comunicação é baseada em critérios nada objetivos. Também, como já apontado, o tema do encarceramento é socialmente invisível, portanto, não tem apelo midiático, exceto em situações de crise.

Apesar desses limites, que de antemão apontam para uma reduzida cobertura jornalística sobre o tema, dois fatores induziram à adoção da estratégia. O primeiro, refere-se ao que Adorno (1991, p. 28) menciona como sendo o "embaralhamento entre o visível e o invisível" no ambiente prisional, mecanismo que tem por objetivo manter em segredo 
aspectos repressivos da prisão, ao mesmo tempo em que busca dar visibilidade a elementos que demonstrem sua capacidade de recuperação da população carcerária. De acordo com o autor:

\begin{abstract}
A prisão, como outras instituições de controle repressivo da ordem pública, não é transparente, sendo pouco acessível à visibilidade externa, a não ser em pequenos momentos e situações, como sejam cerimônias institucionais e rebeliões carcerárias [...]. No limite, este embaralhamento entre o visível e o invisível, entre o dizível e o silêncio, entre aquilo que se sabe e aquilo que circula, entre o "real" e a "fantasia" fazem com que qualquer situação seja passível de manipulação favorável ou desfavorável. (ADORNO, 1991, p. 28).
\end{abstract}

Para Adorno, as cerimônias institucionais estão entre as ações a que se quer dar visibilidade. E, muitas vezes, como demonstrado pela cobertura da mídia, a educação está entre esses momentos.

O segundo fator refere-se à dinâmica da cobertura jornalística sobre educação, que é fortemente pautada por governos ${ }^{46}$. No caso da educação em prisões, a partir de 2004, o governo federal desenvolveu iniciativas que estimularam ações tanto no campo pedagógico como no normativo, por meio do projeto "Educando para a Liberdade".

Essa conjuntura teve reflexo sobre a cobertura da mídia, tornando-a uma fonte de informação considerável para os fins desta pesquisa. Nesse sentido, o objetivo de analisar textos jornalísticos não é buscar informações quantitativas sobre as ações empreendidas, mas identificar atores sociais envolvidos nas atividades educativas e apreender quais aspectos do tema educação nas prisões são socialmente visíveis.

\title{
2.3.2 Deu no jornal
}

No período de 2002 a 2008, foram identificados 256 textos com as palavras educação, escola, prisão, penitenciária. Desses, 69 não se relacionavam a práticas educativas em prisões. Eram textos que tratavam de educação, nos quais a palavra prisão foi usada, em grande parte dos textos, ou para caracterizar situações de violência na escola, ou para afirmar a necessidade de políticas educacionais como forma de prevenção à violência. Interessante notar que neste conjunto foram identificados 15 textos de caráter opinativo - cartas, artigos e editoriais -,

\footnotetext{
${ }^{46}$ Ver: GRACIANO, Mariângela; GONZALEZ, Marina; MODÉ, Giovanna. A cobertura da educação na mídia algumas recomendações para a democratização do debate. Observatório da Educação/Ação Educativa. 2007. Disponível em: <http://www.observatoriodaeducacao.org.br/images/publicacoes/ pdfs/coberturadaeducacao.pdf $>$. Acesso em: 20 jun. 2009.
} 
enquanto entre os 187 textos que tratavam de educação no ambiente prisional, apenas um artigo de opinião foi identificado.

Os textos foram classificados segundo a conceituação proposta por Trilla (2009), inclusive no que se refere aos processos de formação para os exames de certificação. De acordo com este autor, embora os exames de certificação estejam previstos nas leis que regulam a educação, não há normas para o processo de preparação, que acontece inclusive à revelia do sistema de ensino, portanto, não formal. (VARON; XIMENA; UBAL, 2009) No caso das prisões paulistas, os candidatos são preparados por monitores sentenciados, que recebem formação de estagiários contratados pela Funap (GRACIANO, 2005; CARREIRA, 2009).

Entre os 187 textos publicados, 40,1\% estão relacionados à educação formal, incluindo a educação básica e o ensino superior; 33,2\% referem-se à educação não formal e 26,7\% são notícias de temas relacionados à educação nas prisões, sem menção a atividades educativas realizadas.

No conjunto de textos relacionados à educação formal, 33,3\% relatam ações ou pronunciamentos de governantes referentes à educação básica e 66,7\% estão relacionados ao ensino superior. Mesmo considerando o total de textos, nota-se que o ensino superior tem a maior quantidade de informações divulgadas, ocupando $26,7 \%$ dos textos identificados.

A predominância da visibilidade sobre o ensino superior contrasta com a baixa escolaridade da população carcerária nacional. De acordo com dados do Ministério da Justiça, em 2008, 70\% dos presos não concluíram o ensino fundamental, outros 10,5\% são completamente analfabetos, $8 \%$ têm ensino médio completo, portanto estão em condições de cursar o ensino superior, $2 \%$ ingressaram, mas não concluíram este nível de ensino, e outros $2 \%$ já concluíram o ensino superior.

Tabela 20 - Textos jornalísticos pesquisados - 2002 e 2008

\begin{tabular}{|c|c|c|c|c|c|}
\hline \multicolumn{2}{|l|}{ Educação Formal } & \multicolumn{2}{|c|}{ Educação Não formal } & \multicolumn{2}{|c|}{ Temas relacionados } \\
\hline 75 & $40,1 \%$ & 62 & $33,2 \%$ & 50 & $26,7 \%$ \\
\hline Educação Básica & Ensino Superior & Alfabetização & Outros cursos & \multicolumn{2}{|c|}{ Temas relacionados } \\
\hline 25 & 50 & 25 & 37 & \multicolumn{2}{|c|}{50} \\
\hline $13,4 \%$ & $26,7 \%$ & $13,4 \%$ & $19,8 \%$ & \multicolumn{2}{|c|}{$26,7 \%$} \\
\hline
\end{tabular}

A maior parte dos textos sobre o ensino superior (24) refere-se à realização do Exame Nacional do Ensino Médio - Enem em unidades prisionais, visando à classificação para ingresso na universidade. Vale destaque para duas notícias publicadas em 2006, informando 
que o governo estadual do Pará não autorizou a realização do exame no sistema prisional daquele Estado. O segundo tema de maior destaque, com 18 notícias, é a participação de pessoas encarceradas no vestibular. Sete textos relatam a experiência de implantação da graduação em serviço social em um presídio feminino do Rio Grande do Sul e, por fim, há uma reportagem que informa a atuação do Comando Vermelho ${ }^{47}$ na concessão de bolsas de estudos no curso de Direito, para formar profissionais que atuem na defesa de seus membros.

As notícias da educação básica são referentes a ações governamentais desenvolvidas por órgãos gestores da educação pública, em parceria com aqueles responsáveis pela administração penitenciária. Nota-se que algumas das matérias reproduzem depoimentos de gestores anunciando ações a serem implementadas, mas não foram identificados textos informando sobre sua efetivação.

Entre as reportagens relacionadas à educação básica, destaca-se um conjunto de nove textos com informações que tratam da atuação dos professores das redes públicas de ensino no sistema prisional. Dessas matérias, uma traz o relato de uma professora sobre seu trabalho (2004) e as demais são referentes ao embate entre profissionais da educação e governo do Distrito Federal sobre a remuneração adicional aos professores de atuam em presídios. Este foi um tema recorrente em diferentes anos, e a única referência encontrada, no período, foi sobre a mobilização de professores em relação à educação nas prisões.

\subsubsection{As práticas não formais}

Entre os 62 textos que traziam informações sobre atividades de educação não formal, a maioria (25) falava de processos de alfabetização, sendo 23 referências a ações desenvolvidas por entidades da sociedade civil, uma por pessoa voluntária e uma por universidade.

As entidades citadas como promotoras de ações de alfabetização em presídios em diferentes Estados do País, atuando em parceria com governos locais ou por meio de parceria estabelecida diretamente com direções de unidades prisionais, foram: Alfabetização Solidária, Alfabetização através da literatura - Alfalit (BA); Central Única dos Trabalhadores (CUT), Fundação Banco do Brasil, Fundação Bradesco, Fundação Getúlio Vargas, Fundação Roberto Marinho, Fundação Vale do Rio Doce, Grupo Tortura Nunca Mais (BA), Instituto Paulo Freire e Serviço Social da Indústria (Sesi).

\footnotetext{
${ }^{47}$ De acordo com o texto, trata-se de um grupo organizado por criminosos, com atuação dentro e fora dos presídios.
} 
Os textos informavam que algumas das iniciativas eram desenvolvidas no âmbito do programa Brasil Alfabetizado, principal ação do governo federal no campo da alfabetização de adultos. Em 2007, o conjunto de matérias identificado relacionava-se a denúncias de irregularidades na utilização dos recursos federais na execução do programa. As denúncias apontavam para estudantes fantasmas, cadastrados para efeito de repasse de recursos, que já se encontravam em liberdade.

Além de ações de alfabetização, a cobertura da mídia apontou a diversificação de temas e ações dos quais se ocupavam a sociedade civil e pessoas voluntárias no cárcere. Fazia parte deste mosaico de iniciativas: projetos de incentivo à leitura e constituição de bibliotecas, preparação da população carcerária para o exame de certificação, atividades de profissionalização, inclusão digital, educação ambiental e cursos de idiomas.

\section{Tabela 21 - Educação formal e não formal em prisões 2002-2008 - cobertura de jornais}

\begin{tabular}{|c|c|c|c|c|c|c|c|c|c|}
\hline Classificação & Caracterização & 2002 & 2003 & 2004 & 2005 & 2006 & 2007 & 2008 & Total \\
\hline \multicolumn{10}{|l|}{$\begin{array}{l}\text { Educação } \\
\text { Formal }\end{array}$} \\
\hline & Educação Básica & & & & & & & & \\
\hline & Ações governos & 2 & 4 & & 1 & 6 & 2 & 1 & 16 \\
\hline & Condição docente & & 1 & 4 & & 2 & 2 & & 9 \\
\hline & Ensino Superior & & & & & & & & \\
\hline & Enem & 8 & & & 5 & 8 & 3 & & 24 \\
\hline & Vestibular & 1 & 8 & 2 & 4 & 1 & 2 & & 18 \\
\hline & Graduação em presídio & & 1 & & 3 & 3 & & & 7 \\
\hline & $\begin{array}{l}\text { Bolsa Comando } \\
\text { Vermelho }\end{array}$ & 1 & & & & & & & 1 \\
\hline \multicolumn{10}{|l|}{$\begin{array}{l}\text { Educação } \\
\text { Não Formal }\end{array}$} \\
\hline & Alfabetização & & & & & & & & \\
\hline & $\begin{array}{l}\text { Entidades da sociedade } \\
\text { civil }\end{array}$ & 4 & 5 & 2 & 3 & 1 & 7 & 1 & 23 \\
\hline & Voluntário (a) & 1 & & & & & & & 1 \\
\hline & Universidades & & 1 & & & & & & 1 \\
\hline & Outros cursos & & & & & & & & \\
\hline & $\begin{array}{l}\text { Incentivo à } \\
\text { leitura/bibliotecas }\end{array}$ & 1 & 4 & & 4 & 1 & 2 & & 12 \\
\hline & Exame para certificação & 2 & 5 & & 2 & 2 & & 1 & 12 \\
\hline & Inclusão digital & 1 & 2 & 1 & 1 & 2 & & & 7 \\
\hline & Profissionalização & & & & & & 2 & & 2 \\
\hline & Educação ambiental & & & & & 1 & & & 1 \\
\hline & $\begin{array}{l}\text { Idiomas/empreendedoris- } \\
\text { mo/crochê }\end{array}$ & 1 & & & & & & & 1 \\
\hline & $\begin{array}{l}\text { Ações indefinidas - } \\
\text { Universidade }\end{array}$ & 1 & & & 1 & & & & 2 \\
\hline Total & & 23 & 31 & 9 & 24 & 27 & 20 & 3 & 137 \\
\hline
\end{tabular}


Em relação à atuação das universidades, foram identificadas três formas de atuação. A primeira, uma experiência de alfabetização; a segunda, o desenvolvimento de dois projetos de incentivo à leitura, realizados em diferentes Estados; a terceira, narrativa de intervenções pontuais, às vezes de um dia, nas quais se realizavam ações de assistência, como atendimento jurídico e médico, além de palestras, classificadas como "atividades educacionais", sem dados mais precisos sobre temas abordados e pessoas responsáveis, entre outros.

Ainda sobre a atuação das universidades, em julho de 2005, a revista IstoÉ publicou matéria intitulada "Indicadores do bem", que divulgava o resultado de uma pesquisa feita pela empresa Franceschini Análises de Mercado, a pedido do Sindicato das Entidades Mantenedoras de Estabelecimentos de Ensino Superior do Estado de São Paulo (Semesp), sobre a atuação de instituições privadas de ensino superior do Estado em ações de "responsabilidade social” (MORAES, 2005).

De acordo com a pesquisa, $88 \%$ das 291 instituições que participaram do estudo realizavam atividades nas áreas da Saúde, Educação, Cultura, Meio Ambiente e Direito. Um dos exemplos citados na reportagem é o projeto "Leitura Livre", de incentivo à leitura à população carcerária, desenvolvido pela Fundação Escola de Sociologia e Política de São Paulo, um dos casos estudados neste trabalho.

O incentivo à leitura e a constituição de bibliotecas por meio de doação de livros foram as ações de maior visibilidade por meio da mídia impressa, ao lado dos exames de certificação.

Entre os agentes promotores das iniciativas, há algumas instituições de ensino, como a Fundação Escola de Sociologia e Política (SP), o Centro Universitário UniRitter (RS) ${ }^{48}$ e a Universidade do Extremo Sul Catarinense (Unesc) ${ }^{49}$. Nesta última, as ações foram desenvolvidas em resposta a uma solicitação da Justiça. O texto não traz detalhes, mas juntamente com outras ações descritas a seguir, trazem um novo elemento para reflexão: a ação do Poder Judiciário na determinação ou indução na realização de atividades educativas nas prisões. Este foi um aspecto que a pesquisa de campo, realizada em São Paulo, não havia trazido, mas é de suma importância para a compreensão do conjunto de atores responsáveis pela educação nas prisões.

\footnotetext{
${ }^{48}$ Ver: TRIBUNA DO BRASIL, 27/04/2007 e FOLHA DE S. PAULO, 14/04/2007

${ }^{49}$ Ver: A NOTÍCIA (SC), 7/9/2003.
} 


\subsubsection{Os atores}

Além das universidades, iniciativas de governos, organizações e pessoas voluntárias também foram divulgadas no período. De maneira geral, os textos relativos a estes protagonistas não trazem informações detalhadas sobre o alcance da ação, seja quando realizadas por governos (GIOBBI, 2005; BORGES, 2003), por organizações da sociedade civil (ZERO HORA, 8/12/2005) ou pessoas voluntárias. São textos que enaltecem o trabalho, ou melhor, seu simples anúncio, e seus idealizadores, sem elucidar as condições de concretização. Mesmo quando realizadas por governos, as ações não são universais, atendendo apenas a algumas unidades prisionais e, geralmente, contando com doações de organizações da sociedade civil ou atrelando a elas campanhas de doação de livros.

Exemplar nesse sentido é a notícia sobre o projeto "Biblioteca ambulante", que anuncia o programa "Caixa-Estante", existente há 37 anos, e é desenvolvido pela Secretaria de Educação do Governo do Distrito Federal com o objetivo de fazer chegar, por meio de uma biblioteca ambulante, livros às escolas públicas, hospitais "e até presídios". A matéria anunciava, com bastante otimismo, a chegada do programa aos estudantes do ensino médio, graças à doação de títulos feita pela Fundação Nestlé, e também fornecia os contatos para que doações fossem feitas (BORGES, 2003).

Em relação às ações de pessoas voluntárias, os jornais noticiaram a realização da "Expedição Vagalume”, iniciativa protagonizada por três jovens de São Paulo, que por meio da Lei Rouanet de incentivo à cultura, conseguiram recursos de empresas privadas para a constituição de bibliotecas, doadas a 92 comunidades rurais da Região Amazônica. As estantes para a organização dos livros foram fabricadas por sentenciados do presídio Metropolitano de Marituba, no Pará, "que também receberam uma biblioteca" (OLIVEIRA, 2003).

O conjunto das ações revela que apenas os projetos das universidades são desenvolvidos especificamente para a população carcerária, ainda que também sejam focalizados em poucas unidades. Como demonstrando anteriormente, os demais são iniciativas destinadas a diferentes públicos, que têm em comum a vulnerabilidade socioeconômica.

Se, de um lado, esta constatação indica a ausência de iniciativas que garantam direitos culturais à população carcerária, fazendo chegar a ela a sobra, ou uma versão um tanto piorada daquilo que é destinado à população pobre (RUSCHE; KIRCHHEIMER, 2004, 
p.120), de outro, nas ações focalizadas, aponta os riscos da interpretação sobre o que seria exclusivamente adequado à população carcerária.

Tomando o acervo de duas das iniciativas relatadas pela imprensa para efeito de comparação, verifica-se que o projeto "Caixa-Estante" disponibilizava títulos clássicos da literatura brasileira e estrangeira, enquanto a ação desenvolvida pela Universidade do Extremo Sul Catarinense (Unesc), por solicitação do Poder Judiciário, ao iniciar a campanha de doações para constituição da biblioteca, estabeleceu que seriam aceitos apenas "livros didáticos, religiosos, de autoajuda e romances, excetuando-se os livros policias - e revistas" (A NOTÍCIA, 7/9/2003).

Os critérios de doação anunciados são coerentes com os registros existentes sobre os acervos de bibliotecas, ou salas de leituras, instaladas em prisões, não só no Brasil, mas também em outros países da América Latina ${ }^{50}$ : "Prevalecem livros didáticos e para-didáticos ultrapassados e obras de autoajuda [...] entre outros, faltam livros de Direito, em especial direitos humanos e referências sobre direitos da população carcerária" (AÇÃO EDUCATIVA et al., 2008, p. 5). A esses se somam livros fundamentados em experiências da religião espírita, conforme observado nas bibliotecas de algumas unidades de São Paulo. Como tudo nas prisões, as bibliotecas também variam em forma e organização de acordo com a direção da unidade. Assim, também em São Paulo, pode-se constatar a constituição de acervos diversificados, apesar de pequeno, formados por livros em bom estado da literatura brasileira e estrangeira, assim como algumas dispõem de livros de Direito.

Para além da constituição do acervo, as bibliotecas guardam outras especificidades, marcadas pela disciplina - ou violência - inerentes à prisão. Por exemplo, os critérios de acesso. Há unidades que permitem que toda a população frequente e faça empréstimos; em outras o acesso é limitado às pessoas que participam de alguma atividade socioeducativa desenvolvida no ambiente da escola, restringindo a circulação. Há ainda o relato de um dirigente de unidade que afirma garantir o acesso de toda a população aos livros, por meio de um sistema de empréstimo itinerante, onde um sentenciado dispõe os livros sobre uma mesa com rodas, e percorre os corredores recebendo e entregando livros.

Há também o desafio da organização e atendimento, em geral sob a responsabilidade das pessoas sentenciadas, que muitas vezes não tem a formação necessária para atender às solicitações do grupo (GRACIANO, 2005).

\footnotetext{
${ }^{50}$ Ver: Informe preliminar sobre Educação de Mulheres Encarceradas. Disponível em: http://www.acaoeducativa.org.br/portal/index.php? option=com_content\&task=view\&id=1216. Acesso em: 12 fev. 2009.
} 
E ainda os conflitos da prática da leitura com as regras de punição. Há relatos da destruição de livros durante as constantes revistas às celas e castigos para as pessoas que atrasam a entrega ou perdem os livros emprestados. (CARREIRA, 2009; MENDES, 2001).

Novamente, evoca-se o jogo proposto por Adorno, entre a luz e a sombra nas prisões. As iniciativas de incentivo à leitura estão entre aquelas que recebem mais visibilidade social por meio da mídia. No entanto, o foco da informação recai sobre seus promotores, associando-os ao campo da responsabilidade social, solidariedade e agentes da cidadania. $\mathrm{O}$ universo da prisão, ou como os livros serão assimilados a ele, permanece em segredo, na sombra.

\subsubsection{Exame de certificação}

A realização dos exames de certificação da educação básica teve a mesma visibilidade que os projetos de incentivo à leitura. Os textos são, em geral, a reprodução dos informes oficiais produzidos pelos órgãos responsáveis pela gestão da educação pública. Há informações sobre a realização de exames de responsabilidade dos governos estaduais, mas também do exame nacional de certificação (Exame Nacional para a Certificação de Competências de Jovens e Adultos - Encceja). Parte dos textos é de prestação de serviços, anunciando a data e horário da realização dos exames, e outros trazem balanço do número de participantes. Nos dois casos, há apenas a menção ao fato de os exames se estenderem às penitenciárias, assim como hospitais.

Em 2008, houve uma referência, no jornal Folha de S.Paulo (12/8/2008) à realização do Encceja a um Centro de Detenção Provisória (CDP). A notícia é relevante por registrar uma ação educativa em instituição destinada, oficialmente, às pessoas que ainda aguardam sentença. Historicamente, em São Paulo, as atividades de educação e trabalho realizadas pelo Estado não eram estendidas a essas unidades, sob o argumento que os deveres do Estado, previstos na Lei de Execução Penal, contemplam apenas as unidades penitenciárias, onde são cumpridas as penas estabelecidas. As estatísticas, no entanto, indicam que, em virtude da superlotação das penitenciárias, essas unidades terminam por abrigar pessoas já sentenciadas ${ }^{51}$.

\footnotetext{
${ }^{51}$ Ver página eletrônica da SAP: <http://www.sap.sp.gov.br/> e do Ministério da Justiça: $<$ http:// www.mj.gov.br>.
} 
Ao longo do período desta pesquisa, foram identificadas iniciativas de alfabetização e preparação para os exames de certificação empreendidas por agentes de segurança dos CDPs, em acordo com a direção da unidade e à revelia da Funap. Nestes casos, a adesão ao exame é feita por meio do estabelecimento de relação direta entre a unidade prisional e o MEC.

Por organizarem-se de maneira autônoma aos processos oficiais de alfabetização e preparação para os exames, as condições para a realização das atividades educacionais nos CDPs são ainda mais precárias: falta espaço físico, e todo o material - cadernos, material didático, lousa, giz - é conseguido por meio de doações.

A matéria que registrou a realização do Encceja em um CDP do interior de São Paulo, no entanto, não trouxe nenhum tipo de informação sobre a realidade dessas unidades. Da mesma forma, nos textos que registravam a realização dos exames nas penitenciárias, não há nenhuma menção ao processo de preparação dos candidatos. No caso de São Paulo, também não houve menção à falta de material didático, à ausência de professores habilitados, à descontinuidade das aulas, à justaposição entre os horários das aulas e das oficinas de trabalho (GRACIANO, 2005). Novamente, o jogo de luz e sombra.

\subsubsection{Inclusão Digital}

Iniciativas para a inclusão digital da população carcerária foram divulgadas em sete textos. Destes, apenas um consistia em reportagem específica sobre o tema, relatando a visita de um consultor da Unesco, em 2003, aos responsáveis pelo projeto Crisálida de Alfabetização Digital. O trabalho é fruto de uma pesquisa de Doutorado do programa de pós-graduação de Engenharia de Produção da Universidade Federal de Santa Catarina.

A matéria ressaltava que o projeto era o único brasileiro a integrar o Observatório Internacional de Educação em Prisões e informava que havia formado 30 mulheres sentenciadas, tendo paralisado as atividades em virtude de problemas técnicos com a unidade móvel utilizada. Registrou ainda que o veículo-escola pertencia ao Serviço Nacional de Emprego e que o projeto tinha sido realizado com o apoio das Secretarias estaduais da Justiça e Cidadania e do Bem-Estar Social e da Família (DIÁRIO CATARINENSE, 28/1/2003).

Embora as informações disponibilizadas permitam reflexões sobre o compromisso do Estado para com a atividade - paralisar um projeto por problemas no veículo, tendo apoio de órgãos de governo é quase incrível -, o texto não avança sobre indagações que permitissem apreender qual seria a responsabilidade de cada uma das partes na concretização da ação ou, 
dito de outra forma, o que significam as parcerias entre Estado e sociedade civil na realização de atividades educativas na prisão.

Duas pequenas notas informativas dos diários gaúchos Zero Hora e Correio do Povo, em 2006, anunciavam aulas de informática para os internos do presido de Santa Rosa, promovidas pela Fundação Educacional Machado de Assis (Fema), que oferece curso superior, ensino técnico e administra uma rádio educativa ${ }^{52}$. De acordo com o texto, também participava da iniciativa o Conselho da Comunidade da Execução Penal.

Essa foi a única referência ao órgão encontrada no levantamento realizado, mas contribui com a finalidade dessa pesquisa, ao acrescentar outro ator social no campo da educação nas prisões. O papel que estes órgãos vêm desempenhando em todo o País ainda carece de análises, mas importa relacioná-lo quando buscamos identificar as possíveis formas de atuação da sociedade no cenário nacional, um dos objetivos do próximo capítulo ${ }^{53}$.

Os demais textos eram matérias institucionais, que relatavam os projetos de inclusão digital do Centro de Democratização da Informática (CDI) e do Banco do Brasil.

De acordo com o texto do Diário de Pernambuco (13/4/2005), a atuação do banco estatal consiste na instalação de telecentros em bairros de diversos Estados brasileiros; no caso de Pernambuco, a experiência foi levada ao presídio Aníbal Bruno e à Colônia Penal feminina do Bom Pastor.

Outros três textos relatavam a atuação do CDI no processo de inclusão digital de comunidades empobrecidas e marginalizadas, e citavam a atuação em unidades prisionais do Rio de Janeiro ${ }^{54}$.

O texto de O Globo (2003) ao informar sobre o trabalho desenvolvido nas prisões, explica que são ministradas aulas de introdução a diversos programas, mas "a exceção é o uso da internet, já que há restrições em relação à comunicação dos presos".

A atuação do CDI em prisões tinha sido identificada na Penitenciária Feminina da Capital, em São Paulo, durante a realização do mestrado que estimulou este estudo. No entanto, quando da realização da pesquisa de campo nessa mesma unidade, no segundo semestre de 2008, o trabalho da ONG estava suspenso, o que impossibilitou que fosse incluído entre os estudos de caso.

\footnotetext{
${ }^{52}$ Ver: ZERO HORA, 30/4/2006 e CORREIO DO POVO, 30/4/2006.

${ }^{53}$ Os Conselhos da Comunidade são órgãos estabelecidos nos artigos 80 e 81 da Lei de Execução Penal (LEP/1984) e têm por atribuição: visitar, pelo menos, mensalmente, os estabelecimentos penais existentes na Comarca; entrevistar presos; apresentar relatórios mensais ao Conselho Penitenciário e ao juiz da execução, especificando as contas; e diligenciar a obtenção de recursos materiais e humanos para melhor assistência ao preso ou internado, em harmonia com a direção do estabelecimento.

${ }^{54}$ Ver: O GLOBO, 11/4/2003; ALVES, 2004; O GLOBO, 15/12/2004; LEAL, 2002.
} 
Para efeito da análise da cobertura da mídia em relação aos projetos de inclusão digital, e também para assegurar a mais abrangente quantidade de informações sobre as práticas de educação não formal desenvolvidas por organizações da sociedade civil em São Paulo, durante o processo de redação deste trabalho foi feito contato com o escritório do CDI neste Estado, o que permitiu trazer alguns novos elementos para traçar o panorama da das iniciativas não governamentais desenvolvidas em prisões.

$\mathrm{Na}$ capital paulista, o $\mathrm{CDI}^{55}$ mantém laboratório de informática em duas unidades femininas - na Penitenciária Feminina da Capital (PFC) e no Centro de Atendimento Hospitalar à Mulher Presa. Na PFC, o trabalho havia sido paralisado em 2008, em razão de mudanças no quadro de funcionários da instituição, e retomado em agosto de 2009. O trabalho consiste na doação de computadores, formação e acompanhamento de internas que atuam como monitoras de informática, multiplicando o conhecimento entre a população carcerária.

O curso tem duração de quatro a seis meses, com duas aulas semanais de duas horas cada, e as turmas são de dez alunas. Para atuar nas unidades paulistas, o contato é feito por meio da Funap, que remunera a monitora a sentenciada. Sobre a restrição de uso da internet, o CDI apresentou proposta de uso limitado, de maneira a possibilitar a navegação em páginas eletrônicas predeterminadas pelos dirigentes da unidade, mas foi recusada, sob a alegação de questões de segurança.

A prisão não é um foco prioritário de atuação da ONG em virtude da dificuldade de obtenção de financiadores, e o trabalho é desenvolvido de maneira pontual, com recursos de projetos não específicos. O CDI avalia que seja necessário refletir sobre a sua prática nas prisões para consolidar a metodologia, uma vez que as restrições impostas apresentam-se como desafios à adaptação do seu trabalho em diferentes comunidades.

$\mathrm{O}$ argumento das razões de segurança para impedir o uso controlado da internet é um entre tantos outros exemplos da forma como se dá o exercício do poder, por meio das normas disciplinares, em relação às ações de educação nas prisões. Demonstra e reforça a assimetria das relações (FOUCAULT, 1979, p. 248-251), não apenas das pessoas sentenciadas em relação aos agentes da segurança, mas também desses em relação aos educadores.

De onde veio a determinação para a não utilização controlada da internet? Não existem leis que tratem do tema ou tampouco orientações emanadas dos órgãos gestores, mas é interessante que tanto o trabalho no Rio de Janeiro como o de São Paulo, para usar dois

\footnotetext{
${ }^{55}$ Informações obtidas por meio de entrevista com Emerson Almeida, gestor do CDI, em 22/11/2009.
} 
exemplos explicitados, esbarram no mesmo argumento, a ponto de o texto publicado no jornal explicitar esta restrição como algo óbvio - natural.

Como em outras situações relacionadas às atividades de educação, o discurso verdadeiro, que deve ser observado, é aquele produzido pela lógica da segurança. Impossível identificar o autor desse discurso, uma pessoa, um órgão com poder para impor a norma e defendê-la, sustentá-la com argumentos racionais, apenas se consegue observar seus resultados, suas consequências.

Nas palavras de Foucault (1979, p. 248): “o poder não existe [...] é um feixe de relações mais ou menos organizado, mais ou menos coordenado, mais ou menos piramidalizado, mais ou menos coordenado" . Para compreender seu efeito sobre as ações realizadas ao campo educacional, é preciso aceitar a proposição do autor quanto à necessidade de "munir-se de princípios de análise que permitam uma analítica das relações de poder".

Para esta pesquisa, interessou analisar as relações de poder estabelecidas entre educadores e agentes públicos responsáveis pela gestão da prisão ou, em outras palavras, entre as organizações da sociedade e o Estado, um dos temas do próximo capítulo.

\subsubsection{Profissionalização}

Apenas duas matérias foram identificadas sobre o tema do ensino profissionalizante. Ambas relatavam anúncio, por parte de governos locais, de ações na área. Em Brasília (TRIBUNA DO BRASIL, 2007), o governador anunciava a ampliação da oferta de cursos já realizados nos presídios do Distrito Federal, como alfaiataria, oficina mecânica, marcenaria e panificação, a fim de garantir que " $50 \%$ dos detentos estejam trabalhando, estudando, ou fazendo as duas coisas".

Em Mato Grosso (DIÁRIO DE CUIABÁ, 2007), a matéria informava sobre a parceria estabelecida entre o governo estadual, o Poder Judiciário e o Serviço Nacional de Aprendizado Industrial (Senai), destinada à "maior capacitação técnica de reeducandos do país". O texto não especifica todos os cursos que seriam disponibilizados, e o único exemplo citado é o de preparo de salgados finos, previsto para ser realizado em uma unidade feminina. Mas anuncia o critério de seleção: "todos os reeducandos foram selecionados pela Secretaria de Justiça e Segurança Pública de acordo com o comportamento dentro do presídio e afinidade com os temas das aulas". 
Destaca-se a participação do Poder Judiciário na iniciativa, com um importante detalhe: a juíza responsável será a responsável pela "fiscalização da capacitação". Seria particularmente interessante a verificação do processo de implementação desta iniciativa, pois é a única referência encontrada sobre "fiscalização" das atividades propostas, ainda mais a ser feita por uma juíza.

O comportamento como critério de seleção para o acesso aos cursos também é um tema que suscita reflexões no atual contexto da prisão. Em tempos de prisão disciplinar, a expressão remeteria à obediência às regras impostas pelo aparato de segurança. Como o sistema prisional está marcado por elementos que aludem à prisão pós-disciplinar, o "bom comportamento" pode significar a atuação nos novos arranjos relacionais e se vincular aos sistemas de privilégios estabelecidos entre população carcerária e funcionários, como indica G., uma das educadoras entrevistadas para esta pesquisa, ao constatar que os participantes da atividade proposta eram evangélicos e/ou membros do grupo (partido) que comanda a unidade em questão ${ }^{56}$.

Seja qual for o significado, o fato é que utilizar o comportamento como critério de seleção, sobretudo quando o tempo de duração da atividade pode ser usado para efeito de remição da pena, como era o caso descrito na reportagem citada, é submeter sua função pedagógica à lógica da punição, conforme explica Foucault (1987, p. 159) na descrição dos pequenos mecanismos penais que funcionam no interior dos sistemas disciplinares

É interessante notar que esta sanção, a exclusão da possibilidade de frequentar um curso profissionalizante, constitui-se num ilegalismo (1987, p. 228-256), ao contrariar explicitamente a Lei de Execução Penal, que estabelece o acesso à educação e ao trabalho como parte constitutiva da própria pena.

Por fim, a identificação de apenas dois textos sobre atividades de formação profissional pode ser interpretada de acordo com as reflexões de Bauman (1999, p. 119-120), que constata que o trabalho não é mais o elemento organizador da prisão em razão da escassez de empregos, característica da pós-modernidade. A ausência de investimentos na formação de mão de obra, ou mesmo a sua utilização é confirmada pelo reduzidíssimo número de ações desse tipo identificado neste trabalho - apenas um era desenvolvido em condições muito precárias, como será apresentado no Capítulo 3.

\footnotetext{
$\overline{{ }^{56} \text { Ver mais informações sobre o tema no Capítulo } 3 .}$
} 


\subsubsection{Outras considerações}

No período analisado, houve a publicação de outras duas reportagens, relatando atividades de educação não formal nas prisões. Em 2002, o Jornal do Commercio (PE) ${ }^{57}$ publicou nota anunciando a promoção de cursos de espanhol, empreendedorismo - realizado em parceria com o Sebrae - e crochê, na unidade masculina Aníbal Bruno. A fonte da informação foi a Secretaria da Justiça e Cidadania.

Dois destaques no texto fazem alusão ao comportamento dos presos. O primeiro, a ironia do jornalista em relação ao curso de crochê: "será que os detentos estão determinados a fazer peças do vestuário feminino ou interessados nas agulhas de crochê?"; e, ao final, a fala do diretor do presídio: "esses cursos ajudam a manter a ordem".

A justificativa do diretor da unidade para a realização dos cursos ajuda na compreensão das razões para a existência de ações de educação nas prisões. Ainda que os objetivos das atividades sejam explicitados nas normas como mecanismos para preparar a população carcerária à reinserção social, observando a escassez, precariedade e descontinuidade das ações, é difícil acreditar que o próprio sistema acredite na sua eficácia.

Por outro lado, nas entrevistas, nenhum funcionário do sistema apontou a manutenção da ordem como objetivo, e sustentaram no potencial ressocializador das atividades. Aliás, as entrevistas revelam que grande parte das ações só ocorre por iniciativa pessoal desses funcionários. Falam, nas entrevistas, na necessidade de buscar parcerias e doações para a realização de cursos, mas também de eventos culturais.

Certamente são verdadeiros o empenho e a crença dessas pessoas, assim como as entrevistas com internos e egressos do sistema, e também relatos registrados em obras autobiográficas, demonstram a relevância das atividades, como demonstrado a seguir.

Mas a declaração da direção da unidade revela uma faceta da administração penitenciária, ou da economia do poder, a forma como ele é distribuído e exercido na prisão, além de seus custos - econômicos e políticos. "Existe também o custo propriamente político. Se a violência for grande, há o risco de provocar revoltas; ou, se a intervenção for muito descontínua, há o risco de permitir o desenvolvimento, nos intervalos, dos fenômenos de resistência, de desobediência, de custo político elevado" (FOUCAULT, 1979, p. 217).

A concessão das possibilidades de acessar prazer e conhecimento faz parte do exercício do poder, buscando sua eficácia,

\footnotetext{
${ }^{57}$ Ver: FERREIRA, 2002.
} 
pois, se o poder só tivesse a função de reprimir, se agisse apenas por meio da censura, da exclusão, do impedimento, do recalcamento, à maneira de um grande superego, se apenas se exercesse de um modo negativo, ele seria muito frágil, Se ele é forte, é porque produz efeitos positivos no nível do desejo - como se começa a conhecer - e também no nível do saber. (FOUCAULT, 1979, p. 148).

Por fim, foi publicada reportagem ${ }^{58}$ que narra a realização do projeto "Conquistando a Liberdade", que envolveu 60 presos de duas unidades do Estado do Pará, e consistia, inicialmente, na atuação do grupo em praças e escolas públicas, onde recolhiam o lixo e distribuíam sacos de lixo e material de divulgação de uma campanha de preservação ambiental.

O projeto envolveu diferentes secretarias do governo estadual, mas a proposta partiu de um juiz, daí o envolvimento do Tribunal de Justiça do Estado na ação.

\subsubsection{Temas relacionados}

No período analisado, foram identificados 50 textos, $26,7 \%$ do total, referentes a temas que não faziam referência explícita a atividades educativas, mas sim à educação nas prisões em diferentes aspectos, ou mesmo a relação da prisão com a educação.

\subsubsection{Trabalho para a educação}

Este último grupo reuniu o maior número de textos, 12, que tratam de iniciativas governamentais que têm por objetivo envolver a mão de obra carcerária em atividades de trabalho destinados à educação pública. É o caso do projeto "Segundo Tempo", noticiado em 2003, e desenvolvido pelo Ministério do Esporte, com apoio dos Ministérios da Educação e Justiça, cujo objetivo é a realização de atividades esportivas em escolas públicas, nos horários alternativos às aulas - as bolas utilizadas seriam confeccionadas por presos de 42 unidades do País ${ }^{59}$, e sua versão estadual, organizada pelo governo do Estado do Acre, chamada "Pintando a liberdade" ${ }^{60}$ - A construção e reforma de escolas públicas feitas por detentos de São Paulo

\footnotetext{
${ }^{58}$ AMAZÔNIA JORNAL, 3/4/2006.

${ }^{59}$ Ver: DIÁRIO DA MANHÃ, 24/7/2003; DIÁRIO DE PERNAMBUCO, 23/7/2003; CAFARDO, 2003; JORNAL DO BRASIL, 23/4/2003 e 6/4/2003.

${ }^{60}$ A GAZETA (AC), 1/6/2005.
} 
e Roraima" também foi destaque ${ }^{61}$. Por fim, foi divulgado o projeto "Arca das Letras", impulsionado pelo Ministério do Desenvolvimento Agrário, com o objetivo de distribuir livros para populações rurais, ribeirinhas e caiçaras, no qual o Ministério da Justiça participava cedendo a mão de obra carcerária para a produção das estantes ${ }^{62}$.

Não foi objetivo desta pesquisa analisar o trabalho ofertado, ou imposto, à população carcerária. No entanto, é preciso registrar que este tema tem provocado polêmica desde o surgimento das mais remotas formas de encarceramento como forma de punição de crimes. Ruche e Kircheimer (2004) identificaram que a utilização da mão de obra carcerária adquiriu diferentes contornos, variando de acordo com as necessidades do sistema de produção. Nos momentos marcados pela escassez ou insuficiência de postos de trabalho para as pessoas livres, a mão de obra carcerária é desprezada, sob pena de gerar revolta social.

Foucault (2006), no entanto, afirma desconfiar que o desentendimento entre pessoas presas e livres em torno do acesso aos postos de trabalho foi deliberadamente provocado para o funcionamento do sistema de produção organizado pela burguesia, no qual a riqueza e os meios de produção para gerá-la ficam sob o domínio real dos operários, nas fábricas. Para proteger sua riqueza das pessoas que a produzem, é necessário impedir desmandos e revoltas, transformadas em ilegalismos por leis ditadas pela burguesia (MOTTA, MANOEL BARROS, 2006, XXX-XXXI). E, por fim, era preciso que os ilegalismos não fossem tolerados: "O que a burguesia temia era essa espécie de ilegalismo sorridente e tolerado que se conhecia no século XVIII" (FOUCAULT, 2006, p. 162-163) e para atingir este objetivo, a estratégia utilizada foi estimular o medo, o horror, da sociedade em relação aos delinquentes, promotores dos ilegalismos. "Não há por que se surpreender por encontrar hoje no meio da população uma desconfiança, um desprezo, um ódio pelo delinquente: é o resultado de 150 anos de trabalho político, policial” (FOUCAULT, 2006, p. 163).

Bauman (1999) aponta que a pós-modernidade é um dos momentos em que a mão de obra penitenciária é desprezível, uma vez que não há mais trabalho na sociedade, afirmação confirmada pelos dados do Ministério da Justiça, de 2009, em relação ao número de pessoas presas trabalhando, e às atividades realizadas, conforme apresentado no capítulo anterior.

As notícias de jornais, ainda que esparsas, informam de atividades de trabalho estimuladas, ou impostas, pelo Estado, quando estas representam apenas 3,8\% das oportunidades de trabalho para os presos em regime fechado. E o que é noticiado, o que adquire visibilidade pública, é o trabalho a serviço da educação pública de crianças. Nada se

\footnotetext{
${ }^{61}$ O ESTADO DE S. PAULO, 30/08/2005; FOLHA DE BOA VISTA (RR),16/7/2003.

${ }^{62}$ DIÁRIO DO NORDESTE; 7/8/2005; CORREIO BRAZILIENSE, 28/2/2005; COLETIVO (DF), 29/3/2005.
} 
fala sobre a utilização do trabalho carcerário na manutenção das unidades prisionais - $42 \%$ das atividades de laborterapia estão vinculadas a este setor - ou da participação da iniciativa privada, que contribui com $26,4 \%$ das vagas.

Certamente, a publicação dessas reportagens foi estimulada pelos governos, interessados em divulgar tais ações, já que da forma como são construídas, parecem ter o propósito de convencer a população em geral sobre a humanidade dos encarcerados. Esta é uma hipótese bastante possível se consideramos que parte considerável das ações noticiadas foram estimuladas pelo Ministério da Justiça, também responsável pelo programa Recomeço, destinado a egressos do sistema prisional, que, em 2009, fez veicular em emissoras de TV um informe publicitário que buscava despertar a solidariedade e problematizar o preconceito da população em relação a este grupo.

A tentativa de buscar aproximar a população carcerária da sociedade por meio do trabalho "útil", também é utilizada por organizações da sociedade civil. $D$. dirigente de uma organização que foi fundada para atendimento de pessoas presas, contou na entrevista que uma das primeiras ações foi estimular os detentos a acompanhar o cultivo de uma horta, e as verduras e legumes eram destinadas à creche do bairro onde se localizava a organização. A ideia era aproximar os detentos da comunidade local, de uma maneira positiva, para que percebessem que eles não "são monstros".

Também não foi objeto desta pesquisa investigar a utilização e os diferentes e possíveis significados do trabalho da mão de obra carcerária no atual contexto, mas a falta de informações e de análises sobre o tema revela uma lacuna importante para a compreensão do funcionamento da instituição prisão na atualidade.

\subsubsection{Diagnóstico da precariedade}

Um segundo conjunto de textos (dez) foi constituído por notícias que constatavam a precariedade ou inexistência de ações educativas nas prisões brasileiras. Desses, quatro foram notícias da missão realizada pela Relatoria Nacional pelo Direito à Educação a unidades prisionais. A Relatoria é um projeto da rede de organizações de direitos humanos, Plataforma Dhesca-Brasil, desenvolvido desde 2003. A relatora Denise Carreira, no período de 2008 e 2009, visitou unidades prisionais de seis Estados e elaborou relatório descrevendo a situação verificada, além de emitir recomendações para a superação das violações de direitos 
educativos identificados. Todas as matérias referiam-se à missão realizada às unidades pernambucanas $^{63}$.

Os jornais catarinenses, A Notícia e Diário Catarinense, publicaram no mesmo dia 26/10/2008 - textos idênticos, abordando a precariedade ou a inexistência de atividades educativas nas unidades prisionais do Estado, citando dados nacionais e catarinenses sobre a escolaridade da população prisional ${ }^{64}$. Em 2007, o Diário Catarinense tinha publicado entrevista com o coordenador da Pastoral Carcerária no Estado, que fazia a mesma análise sobre as deficiências da educação nas unidades do estado. ${ }^{65}$

O Correio da Paraíba, em 2007, publicou uma longa reportagem sobre o sistema penitenciário estadual, abordando também a ausência de políticas educacionais para a população carcerária ${ }^{66}$.

Em 2003, o Correio do Povo cobriu a visita de Marc De Mayer, assessor da Unesco, ao Brasil, reproduzindo suas observações sobre possíveis propostas pedagógicas para a educação nas prisões ${ }^{67}$.

Em São Paulo, o jornal O Estado de S. Paulo ${ }^{68}$ publicou, em 2006, longa reportagem sobre a oferta de ensino no sistema penitenciário paulista. $\mathrm{O}$ texto trouxe entrevista com detentas da Penitenciária Feminina da Capital, que denunciaram a impossibilidade de frequentar a escola em razão do conflito de horário com as oficinas de trabalho. A reportagem também trazia depoimentos da gestora responsável pela coordenadoria de Educação de Jovens e Adultos da Secretaria Estadual de Educação, que afirmava que o órgão passaria a responsabilizar-se pela educação em prisões, por ser um campo da Educação de Jovens e Adultos, e que um programa específico estava sendo elaborado em parceria com a Secretaria da Administração Penitenciária. O trabalho de pesquisa neste Estado demonstra que o anúncio não se concretizou.

Essa, também, foi a única notícia referente à mobilização de organizações da sociedade civil em defesa dos direitos educativos de pessoas encarceradas. Tratava-se de um abaixo-assinado $^{69}$, subscrito por organizações do campo da educação e dos direitos humanos,

\footnotetext{
${ }^{63}$ Ver: JORNAL DO COMMERCIO (PE), 28/10/2008, 30/10/2008 e FERREIRA, 2008.

${ }^{64}$ Ver: DIÁRIO CATARINENSE. 26/10/2008 e A NOTÍCIA, 26/10/2008.

${ }^{65}$ Ver: DIÁRIO CATARINENSE, 16/7/2007.

${ }^{66}$ Ver: CORREIO DA PARAÍBA, 19/8/2007.

${ }^{67}$ Ver: CORREIO DO POVO, 27/1/2003.

${ }^{68}$ Ver: CAFARDO, 2006.

69 O documento, entregue ao Congresso Nacional em abril de 2006, foi redigido por: Ação Educativa, Associação Juízes para a Democracia, Instituto Terra, Trabalho e Cidadania (ITTC), Pastoral Carcerária de São Paulo, Instituto de Defesa do Direito de Defesa (IDDD), entidades que compõem, dentre outras, o Grupo de Estudos e Trabalho "Mulheres Encarceradas", além de Geledés - Instituto da Mulher Negra, Instituto Paulo Freire e Instituto Paulo Montenegro.
} 
dirigido ao Congresso Nacional, reivindicando a aprovação de projeto de lei que instituísse a remição penal pelo estudo.

Tabela 22 - Temas relacionados à educação nas prisões em geral 2002-2008

\begin{tabular}{|c|c|c|c|c|c|c|c|c|}
\hline Caracterização & 2002 & 2003 & 2004 & 2005 & 2006 & 2007 & 2008 & Total \\
\hline Trabalho para Educação & & 7 & & 5 & & & & 12 \\
\hline $\begin{array}{lrr}\begin{array}{l}\text { Diagnóstico } \\
\text { insuficiência } \\
\text { existentes }\end{array} & \text { das } & \text { ações } \\
\end{array}$ & & 1 & & & 1 & 2 & 6 & 10 \\
\hline Debate sobre o tema & & & & 2 & 7 & 1 & 1 & 11 \\
\hline Projetos de lei & 2 & & & & & 2 & 2 & 6 \\
\hline $\begin{array}{l}\text { Analfabetismo no País } \\
\text { cita situação na prisão }\end{array}$ & & 1 & & 1 & & & & 2 \\
\hline Bolsa Família & 3 & & & & & & & 3 \\
\hline Remição pelo estudo & & & & & 3 & & & 3 \\
\hline Infraestrutura & & & & 1 & 1 & & & 2 \\
\hline Concurso Redação & & & & & & 1 & & 1 \\
\hline Total & 5 & 9 & - & 9 & 13 & 6 & 8 & 50 \\
\hline
\end{tabular}

Os Ministérios da Educação e Justiça pautaram o tema da educação nas prisões em razão das oficinas regionais realizadas para discutir a elaboração de Diretrizes Nacionais para a educação em prisões. Os encontros, realizados a partir de 2005 no âmbito do projeto Educando para a Liberdade, além do anúncio de ações pilotos em alguns Estados foram divulgados pela imprensa escrita. Os textos, de maneira geral, reproduziam informações oficiais sobre o formato da iniciativa ${ }^{70}$.

No período, cinco textos referiam-se às iniciativas de parlamentares federais em criar leis referentes à obrigatoriedade do ensino nas prisões. As notícias refletiam a aprovação dos projetos em comissões específicas, sem haver informações sobre sua tramitação posterior ${ }^{71}$. O Estado de Minas divulgou, em 2002, a Assembleia Legislativa aprovou e o governador sancionou a Lei 11.404/94, estabelecendo a obrigatoriedade do ensino fundamental nas prisões, além de cursos profissionalizantes e ensino médio supletivo ${ }^{72}$. Interessante que nenhum dos textos informou que a determinação da obrigatoriedade da educação básica já estava determinada na Lei de Execução Penal.

Ainda sobre leis, em 2006, o Ministério da Justiça enviou para a Câmara Federal projeto de lei alterando a Lei de Execução Penal, de maneira a estender para as atividades

\footnotetext{
${ }^{70}$ DIÁRIO DO NORDESTE, 15/3/2005; MEIO NORTE (PI), 10/2/2005; PARREIRAS, 2006; O ESTADO DE MINAS, 21/11/2006; TRIBUNA DO PLANALTO (GO), 30/8/2006; ZERO HORA, 2/2/2007; JORNAL DE BRASÍLIA, 14/7/2006; NISKIER, 2006; MACEDO, 2006; HENRIQUES, SILVA e GRACIANO, 4/8/2008. ${ }^{71}$ Ver: A NOTÍCIA, 8/7/2002; JORNAL DO SENADO, 5/12/2007; JORNAL DO SENADO, 18/4/2007; O GLOBO, 3/4/2008; O PARANÁ, 4/4/2008.

${ }^{72}$ Ver: O ESTADO DE MINAS, 28/11/2002.
} 
educativas a possibilidade da remição pelo estudo, a exemplo do que ocorre com o trabalho. A iniciativa provocou três reportagens sobre o tema ${ }^{73}$.

Dois textos abordaram os elevados índices de analfabetismo no Brasil, citando a situação da população carcerária, apontada como público prioritário para as ações de alfabetização $^{74}$.

Dois textos trouxeram informações sobre a intenção de governantes de construir e equipar escolas nas unidades prisionais ${ }^{75}$.

Em 2003, três textos abordaram iniciativas do governo federal ${ }^{76}$ e do governo estadual de Pernambuco ${ }^{77}$, no sentido de incluir as famílias da população carcerária no programa Bolsa Família.

Por fim, foi identificado um texto que anunciava a realização do concurso de redação "Escrevendo a Liberdade", iniciativa do Ministério da Justiça em parceria com a ONG Alfabetização Solidária ${ }^{78}$.

\subsection{Algumas conclusões}

\subsubsection{A produção do silêncio}

Para efeito desta pesquisa, os Ministérios da Justiça e da Educação não disponibilizaram informações sobre as parcerias celebradas com organizações ou pessoas para o desenvolvimento de atividades de educação não formal nas unidades prisionais. O mesmo ocorreu com a Funap/SP, com o agravante que, neste caso, não há informações nem mesmo na página eletrônica da instituição ou outro órgão do setor público paulista.

Há duas hipótes para explicar a impossibilidade de obtenção de dados oficiais relativos à participação de organizações da sociedade civil no desenvolvimento de atividades educativas nas prisões, que não são necessariamente excludentes entre si. A primeira, é que os governos não possuem esses dados, e não os possuem porque não os produziram. A segunda, é que os governos os detêm, mas os mantém em segredo "uma das formas importantes do poder político" (FOUCAULT, 2006, p.70).

\footnotetext{
${ }^{73}$ Ver: COLARES, 2006; KLINGL, 2006; DIÁRIO DE PERNAMBUCO, 2006.

${ }^{74}$ Ver: A GAZETA (MT), 2003; JORNAL DO COMMERCIO (PE), 16/12/2005.

${ }^{75}$ Ver: JORNAL DE BRASÍLIA, 18/1/2006; ZERO HORA, 24/2/2005.

${ }^{76}$ O GLOBO, 3/4/2002 e A NOTÍCIA (SC), 3/4/2002.

${ }^{77}$ JORNAL DO COMMERCIO (PE), 22/1/2002.

${ }^{78}$ MARIZ, 2007.
} 
A primeira hipótese é reforçada pela dificuldade do Departamento de Políticas Penitenciárias (Depen) em manter atualizados dados nacionais básicos sobre o perfil da população carcerária, como se pode observar nos relatórios eletrônicos produzidos pelos sistema InfoPen e disponíveis na página eletrônica do Ministério da Justiça ${ }^{79}$. Para cada um dos itens relacionados há a inclusão de valores assim definidos: "Valor automático de correção de itens inconsistentes - Diferença com relação à população carcerária do Estado". No caso do pertencimento étnico-racial da população carcerária feminina, por exemplo, este índice chega a 15\%, o que significa que os Estados não se empenham em enviar informações ao sistema nacional.

E pode-se indagar se o governo central não tem poder para determinar a transmissão dos dados. Mas a resposta nos é dada por Foucault (1979, p. 150-151): o poder não está no aparelho do Estado, mas "nos mecanismos de poder que funcionam fora, abaixo, ao lado dos aparelhos de Estado a um nível muito mais elementar, cotidiano [...]".

Ao mesmo tempo em que não detêm condições para acessar, analisar as informações relativas ao sistema penitenciário para transformá-lo em dados públicos, os órgãos de governo contribuem para a manutenção do segredo em torno das prisões, mantendo sob sigilo as informações sobre suas próprias ações. A segunda hipótese é que os governos manipulam o "o feixe de poder" que detêm para reforçar a sombra que circunda as prisões, tornando privados dados que são públicos.

\subsubsection{Diversidade e fragmentação}

O conjunto de iniciativas identificadas impressiona pelo volume e pelo caráter pontual. Convênios, protocolos de intenções, cooperação técnica, projetos pilotos, iniciativas filantrópicas, ações destinadas à promoção da cidadania.

São muitos os anúncios de realizações, ou pretensões de ação, mas de alcance sempre limitado, pontual. Também, com exeção do projeto "Educando para a Liberdade", não há qualquer anúncio de avaliação dos resultados dessas iniciativas ou mesmo de seu significado para as pessoas presas.

Embora em contextos muito diferentes, a descrição de Garland (2008, p. 76-77) sobre o campo penal no fim do século XX na Inglaterra, é bastante pertinente ao cenário aqui identificado:

\footnotetext{
${ }^{79}<$ www.mj.gov.br> .
} 
Em resposta à erosão ou ao colapso de uma configuração institucional estabelecida anteriormente, vários tipos de programas e de adaptações rapidamente surgiram para preencher o vácuo. Esta proliferação de novas propostas, esta enxurrada de novas ideias, é eclética, variada e emerge de várias fontes do campo social. [...] Atores socialmente situados, precariamente informados, tropeçam no desenvolvimento das atividades que parecem funcionar e que parecem coincidir com seus interesses. Autoridades arranjam soluções práticas para os problemas que percebem e que podem enfrentar. [...] Cada "solução" é baseada em uma percepção específica do problema que está sendo tratado, dos interesses que estão em jogo e dos valores que devem guiar a ação e distribuir as consequências. (GARLAND, 2008, p. 76-77).

Em relação à educação nas prisões, é preciso considerar que esta profusão de iniciativas, desconexas e desarticuladas entre si, não vêm em substituição a nada, pois a preocupação com o tema, seja no campo da defesa dos direitos de pessoas presas, na produção científica e, sobretudo, nas políticas educacionais é absolutamente recente, conforme demonstram as ações apresentadas anteriormente.

O que é permanente, como será demonstrado nos capítulos seguintes, é a presença de pessoas voluntárias e instituições filantrópicas.

\subsubsection{Quem são os atores}

Não é desprezível a atuação do Estado na tentativa de intervir e estimular ações de educação não formal nas prisões. Aliás, a julgar pelas iniciativas dos gestores do sistema penitenciário, parece haver a crença que a prisão é destinado à práticas não formais, inclusive em substituição à educação formal.

A análise da cobertura do tema pela mídia impresa permitiu a identificação de dois novos atores como indutores de atividades educativas: o Poder Judiciário e o Conselho da Comunidade. A intensidade e os resultados dessas intervenções constituem-se em interessantes temas de pesquisa, mas fogem aos objetivos do presente estudo.

A atuação da sociedade se apresentou de duas formas distintas: como executora de ações, mas também como ator político na exigibilidade de direitos, em consonância com as reflexões de Scarfó (2009), sobre o papel da sociedade na realização dos direitos educativos de pessoas encarceradas.

Verifica-se, na execução das atividades, a variedade de instituições que, a partir da década de 1990, passaram a compor o chamado terceiro setor (Gohn, 2008). São organizações 
de natureza muito diversa, com objetivos institucionais, fontes de financiamento e metodologia de atuação variadas.

Chama a atenção o considerável número de reportagens que cita a presença das instituições do Sistema $\mathrm{S}$ em atividades de educação não formal, notadamente na alfabetização e na formação profissional. Esta forte presença na mídia é coerente com a expectativa dos governos em relação a atuação do grupo nas prisões, existindo inclusive protocolo de intenção firmado no âmbito federal, mas é absolutamente contraditória à sua atuação efetiva. Conforme dados do Ministério da Justiça (2009), a participação do Sistema S, juntamente com outras ONGs não identificadas, na oferta de vagas em ações de laborterapia é irrisória, correspondendo a $1,6 \%$ das vagas, no caso das atividades externas, e $0,4 \%$ das atividades internas, como demonstrado no Capítulo 1.

A presença de pessoas voluntárias, sobretudo vinculadas a igrejas, não é tema de divulgação na imprensa nem foram identificados convênios com igrejas para atuação em atividades educativas nas prisões. Porém, a pesquisa de campo revela sua atuação, silenciosa, discreta, mas firme e permanente ao longo de toda a história da prisão.

Por fim, há a presença da universidade. Presença também diversa, ora por meio de projetos de estudo desenvolvidos por estudantes, que se transformam em estratégias de atuação; outras vezes, por projetos institucionais que também se desenvolvem pela ação de estudantes, no papel de estagiários.

Diferentemente das informações identificadas no âmbito do governo federal, que apontam para uma ação reguladora do Estado, como indutor e financiador de ações, que são formalizadas por meio de convênios, no Estado de São Paulo, o conteúdo das entrevistas com os gestores, e também a precariedade dos registros das informações, traduzem um intenso componente de informalidade e, simultaneamente, de fragilidade dos órgãos de gestão quanto à sua capacidade de induzir ou realizar ações públicas que se estendam por todo o sistema.

Ao mesmo tempo, o tema do financiamento das iniciativas - tanto de âmbito nacional quanto estadual -, remete à necessária reflexão sobre processos de terceirização e privatização da gestão do sistema prisional, outro aspecto a ser abordado a seguir.

O significado de cada uma dessas intervenções será o objeto de reflexão do próximo capítulo. 


\title{
CAPÍTULO 3 - LIMITES E POSSIBILIDADES DA ATUAÇÃO DA SOCIEDADE CIVIL NA EDUCAÇÃO EM DUAS PRISÕES DE SÃO PAULO
}

\author{
Um fato que chama atenção na Detenção é o \\ trabalho voluntário de algumas pessoas. Gente \\ que deixa de estar com a família, ou ganhar \\ dinheiro, para estar numa prisão prestando \\ solidariedade e ajuda aos presos. (JOCENIR, \\ 2001, p. 125).
}

A investigação das atividades educativas realizadas na Penitenciária Feminina da Capital (PFC) e Penitenciária Masculina Parada Neto permitiu identificar iniciativas de organizações da sociedade civil, pessoas voluntárias vinculadas a igrejas, estudantes universitários e representantes de universidades.

Foram realizadas entrevistas com as pessoas responsáveis pelo desenvolvimento de cada uma das iniciativas, exceto das Oficinas Prevenção DST/Aids e da Oficina de Capacitação em Rádio - Universidade Metodista de São Paulo.

É necessário registrar a atuação da Pastoral Carcerária, articulação de voluntários leigos e religiosos vinculada à Igreja Católica, na alfabetização de presos em unidades prisionais de São Paulo. Nas unidades onde foi realizado o levantamento de campo, a Pastoral Carcerária desenvolve trabalho de evangelização e também de defesa de direitos, mas não de educação. No entanto, sua atuação na alfabetização de pessoas presas foi citada em algumas das entrevistas, e o registro da informação contribuiu para a compreensão do objeto deste estudo.

Por fim, entre os grupos "de fora" que atuam nas prisões, foi identificada a presença do Narcóticos Anônimos, definido na página eletrônica da instituição como "associação comunitária de adictos a drogas em recuperação; iniciado em meados de 1953, o movimento de NA é um dos maiores e mais antigos deste tipo, com aproximadamente quarenta mil reuniões semanais em 130 países" ${ }^{\Perp 0}$. E também da Alcoólicos Anônimos, definida em sua página eletrônica como "uma irmandade de homens e mulheres que compartilham suas experiências, forças e esperanças, a fim de resolver seu problema comum e ajudar outros a se recuperarem do alcoolismo" 81 .

\footnotetext{
${ }^{80}$ Disponível em: <http://www.na.org.br/portal>. Acesso em: 7 jan. 2010.

${ }^{81}$ Disponível em $<$ http://www.alcoolicosanonimos.org.br>. Acesso em: 7 jan. 2010.
} 
Sem desconsiderar a importância de compreensão da natureza do trabalho desses grupos no ambiente prisional, essas experiências não foram tomadas para investigação em virtude de seu caráter clínico-terapêutico, o que não se constitui objeto desta pesquisa.

A seguir é apresentada a descrição do trabalho realizado pelos diferentes atores identificados, e a busca da compreensão de seu significado - para os/as educandos/as envolvidas e também para o sistema prisional - será empreendida com base em teóricos que estudam dois campos do conhecimento: a educação e a segurança pública, mais precisamente, o sistema prisional.

As reflexões sobre as possibilidades e os limites das práticas educativas no ambiente prisional estão baseadas nas considerações de Paulo Freire sobre educação e autonomia (1996, 1987, 1983) e de Fichtner (2009); Ribeiro (2009), Nuñez (2009), entre outros, sobre o potencial de controle social existente nas práticas não formais de educação.

A compreensão da inserção dessas práticas no ambiente prisional foi baseada em autores que estudaram o funcionamento das prisões brasileiras em diferentes períodos (SALLA 1997, 2007; ADORNO, 1991a, 1991b; SOARES; ILGENFRITZ, 2002) e as características da prisão, em diferentes países, na atualidade (GARLAND, 2008; CHRISTIE, 1998; CHANTRAINE, 2006; WACQUANT, 2002), entre outros.

\subsection{Quem faz e o que faz}

\subsubsection{Curso Promotoras Legais Populares}

Desenvolvido pela ONG Coletivo para Liberdade e Reinserção Social (Colibri), o curso "Promotoras Legais Populares" (PLP) objetivava a capacitação de mulheres para que tivessem acesso à informação e aos instrumentos jurídicos de proteção para a efetivação de seus direitos. Foi constituído em 1994, estimulado pelo contato de lideranças feministas brasileiras com iniciativas de capacitação legal de mulheres em outros países da América Latina. O curso foi desenvolvido em diversas cidades brasileiras, tendo como público prioritário lideranças comunitárias femininas ${ }^{82}$.

\footnotetext{
${ }^{82}$ Mais informações <http://www.promotoraslegaispopulares.org.br>.
} 
No ambiente prisional, foi realizado uma única vez na PFC, em 2002, por iniciativa do Colibri, com o apoio financeiro da Coordenadoria Nacional de DST/Aids do Ministério da Saúde.

A organização foi fundada no início dos anos 2000, com o objetivo de atuar com a população carcerária. Durante a sua curta existência - o coletivo foi extinto em 2004, por falta de apoio financeiro -, destacaram-se duas iniciativas. A primeira, realizada em parceria com o Coletivo de Feministas Lésbicas, entre 2001 e 2002, constituiu-se de oficinas de prevenção às DST-Aids na Penitenciária Feminina da Capital; e a segunda, foi o curso "Promotoras Legais Populares".

$\mathrm{O}$ apoio do Ministério da Saúde à ONG foi iniciado por meio do primeiro projeto e, depois, estendido para a realização do PLP, mesmo não sendo específico sobre o tema DSTAids. "Não sei como eu consegui convencê-los de que isso [o Curso PLP] modificava o comportamento; e modificava mesmo, sem dúvida, é que modificava num universo pequeno. Também, havia ali [no projeto do curso] uma preocupação de formação de multiplicadores”, conta $A$.

O projeto contou com o apoio da direção da unidade, e a divulgação das inscrições foi feita por meio de cartazes, confeccionados pela ONG e distribuídos pelas dependências da PFC. As inscrições foram feitas no prédio da escola, sob a responsabilidade da equipe que lá atuava. A. acredita não ter havido qualquer restrição à participação das internas no processo de inscrição, e a seleção foi feita pelo Colibri, por meio de uma prova "que não exigia conhecimento, mas redação". O objetivo era garantir que participassem pessoas alfabetizadas, uma vez que o curso exigia a leitura de textos.

A. avalia que a seleção terminou por constituir um grupo com perfil "mais apurado", do ponto de vista da formação, que aquele encontrado nas edições do PLP realizadas fora da prisão. "Acho que selecionei muito... hoje faria um pouco diferente em relação a isso", avalia. De qualquer maneira, o curso não poderia ser universal, ou seja, estendido a toda a população da unidade, pois os recursos eram limitados e permitiam atender um número reduzido de presas.

A. não tem o número exato de inscritas na ocasião, mas a turma foi constituída por aproximadamente 22 ou 23 mulheres e, dessas, 17 receberam o certificado de conclusão em dezembro de 2003, durante a missa de Natal. A população da unidade naquele momento era de aproximadamente 600 mulheres.

Três das mulheres que desistiram o fizeram por pressão de suas “empregadoras", no caso, funcionárias do setor administrativo da unidade, onde as internas prestavam serviços. 
Comentando a relação da equipe de funcionárias da PFC com o curso, $A$. distingue a postura da direção, que a apoiou, daquela adotada por algumas funcionárias: "Se eu disser que tive problemas [com a direção] estou sendo mentirosa, os problemas são menos sofísticados, eles são problemas mais da mesquinharia do poder do carcerário, aquela coisa de não liberar algumas mulheres que trabalhavam na parte administrativa, essas eram as piores, as que trabalhavam mais como peões, tudo bem".

De acordo com a entrevistada, as internas que trabalhavam no setor administrativo são aquelas que têm formação mais qualificada, mas dependiam da proteção das funcionárias para sobreviverem, seja por terem cometido crimes condenados pela população carcerária, por sua beleza ou condição socioeconômica privilegiada.

Para garantir proteção, essas mulheres desenvolviam relação de absoluta submissão com as funcionárias, que, neste caso, não concordaram com sua participação no curso.

“Forma-se ali uma relação de poder que, para a presa, é absolutamente perversa. É como se fosse refém dessa superior administrativa. O que acontece é que você tem o privilegio [trabalhar na administração], você sabe que tem o privilégio se tiver formação, e, já que você teve esse privilégio, vai ter que pagar. Eu perdi alunas assim... Fui lá conversar e elas disseram: 'não quero mais, eu resolvi desistir", explica $A$.

Os encontros eram semanais, com duração de duas horas e meia a três horas. O programa previa encontros de quatro horas, mas não era possível em virtude do período de trabalho nas oficinas instaladas na unidade ou na realização dos serviços gerais da unidade. De acordo com A.: "Elas trabalhavam... era complicado porque tinham que ser liberadas, então era perto da hora do almoço, às vezes elas ficavam sem almoço."

A. não tem notícias de fatos que demonstrem que os conhecimentos adquiridos no curso tenham influenciado ou promovido alterações na vida cotidiana das alunas, ainda prisão. "Elas usavam aquele espaço muito para desabafar sobre as arbitrariedades sofridas [...]. Eu acho também que elas eram muito ciosas da coisa, elas tinham muito medo de perder o curso", justifica.

Não foi possível entrevistar ex-alunas do PLP na pesquisa de campo, afinal, quase sete anos se passaram. No entanto, algumas informações contidas na dissertação "A Educação como direito humano: a escola na prisão" (GRACIANO, 2005) contribuem para compreender a experiência do curso de formação de "Promotoras Legais Populares" na prisão.

A primeira observação é que a pesquisa que originou a dissertação citada foi realizada em 2004, na PFC, e tinha como foco a educação escolar. As entrevistas com as internas seguiam um roteiro focado na vida escolar, anterior e na prisão, e também dos filhos daquelas 
mulheres. Durante as entrevistas, algumas delas citaram o PLP para afirmar que conheciam seus direitos, e de seus filhos, de acesso à educação.

Então, talvez, a apropriação do conhecimento proporcionado pelo PLP se manifeste de formas difusas, mas muito significativas, que extrapolaram o ambiente da prisão e, mesmo nele, surgiram de formas inesperadas, informalmente, por que não dizer, autônomas.

As alunas, tendo se apropriado do conhecimento, fizeram uso dele como, quando e onde puderam, e a ação da monitora sentenciada, no curso de alfabetização, é exemplar neste sentido e ilustra muito bem a reflexão de Paulo Freire (1996, p. 107) sobre a relação entre educação e autonomia:

\footnotetext{
A autonomia, enquanto amadurecimento do ser para si, é processo, é vir a ser. Não ocorre em data marcada. É neste sentido que uma pedagogia da autonomia tem de estar centrada em experiências estimuladoras da decisão e da responsabilidade, vale dizer, em experiências respeitosas de liberdade.
}

A outra observação está relacionada ao grupo selecionado, que participou do curso. Embora $A$. afirme não ter havido seleção por parte das funcionárias, é interessante notar que as mulheres entrevistadas em 2004 tinham um histórico de participação nas atividades educativas ofertadas na prisão. Tinham feito muitos cursos, além de frequentar a preparação para os exames supletivos. Algumas até já tinham concluído a educação básica, mas continuavam a frequentar as aulas. Outras ainda atuavam como monitoras contratadas pela Funap. De uma forma ou de outra, eram mulheres inseridas nas redes oficiais de relações, que acessavam direitos - ainda que precários -, concretizados por meio das atividades.

Tendo em vista o limitadíssimo número de pessoas atingidas pelas ações, se considerarmos que foram as mesmas a participarem de todas, concluímos que a imensa maioria da população carcerária não participa de nada. Este será um tema recorrente nas outras experiências aqui relatadas.

\subsubsection{Projeto Quem Somos Nós}

O Projeto "Quem Somos Nós" é desenvolvido nas penitenciárias femininas da Capital e Santana, ambas na cidade de São Paulo, pelo Instituto Terra, Trabalho e Cidadania (ITTC), com o financiamento da Petrobrás, programa "Fome Zero" (atualmente denominado "Programa Desenvolvimento e Cidadania"), com o objetivo de estimular reflexões de mulheres presas sobre eixos temáticos, discutidos em oficinas e definidos com a participação 
do grupo. Em 2007, o trabalho transcorreu com base nos eixos: cidadania, violência e gênero, com a participação de 165 mulheres, organizadas em grupos de 10 a 15 pessoas. Na Penitenciária de Santana, foram constituídos 22 grupos, e na PFC, três. A capacidade de atendimento da unidade de Santana é de 2.400 mulheres, e sua população, em fevereiro de 2010, era de 2.701; na PFC, no mesmo período, a capacidade era de 251 pessoas, e a população, 783 mulheres.

Para as educadoras responsáveis pelo projeto, $F$. e $P$., os eixos temáticos escolhidos estão relacionados diretamente à realidade das mulheres presas. Violência, abordando as violências que elas praticaram e praticam, mas também aquelas sofridas no presente e no passado - são vidas marcadas por histórias de violência, social e familiar; Gênero, que busca discutir a construção dos papéis sociais entre homens e mulheres, inclusive no mundo do crime; e Cidadania, partindo da noção que cidadania é construída com o exercício de direitos e deveres, portanto, necessita da participação, da atuação das pessoas na vida social - e como participar estando privadas de liberdade? É possível? Quais os caminhos?

Esses foram alguns dos temas discutidos nas oficinas de trabalho, que $F$. e $P$. fazem questão de frisar que não são aulas: “a oficina é uma troca, não é algo que a gente só está levando, mas algo que a gente está trocando com essas mulheres, as experiências delas, e a gente podendo também proporcionar informações”. E os encontros são constituídos de momentos de debates e atividades lúdicas "que permitam reflexão". Há também a produção de material pelas mulheres, como cartazes, música e outros. No momento da entrevista, por sugestão das internas, o grupo estava discutindo a confecção de um jornal para sistematizar o conteúdo de suas reflexões.

O processo de inscrição para participar do projeto é diferente para as duas unidades. Na Penitenciária de Santana, onde há poucas oportunidades de trabalho e atividades de educação, cultura ou lazer, o ITTC dá prioridade para as mulheres que não estejam participando de outras ações. Nesta unidade, tanto a divulgação do projeto quanto as inscrições são feitas pelas "agentes culturais", internas responsáveis pela organização das atividades de cultura, esporte e lazer na unidade.

$\mathrm{Na} \mathrm{PFC}$, em virtude da maior oferta de trabalho e outras atividades, de acordo com as educadoras, não há critérios de seleção. Nesta unidade, a divulgação e a inscrição ficam sob a responsabilidade da equipe que atua na escola. Ali, a procura pelo projeto é bem menor, de acordo com F. e P.: "são mulheres que realmente não estão fazendo nada, mas já estão na fila, esperando vaga para o trabalho". Quando conseguem a vaga, as mulheres abandonam o 
projeto, então, a maior oferta de trabalho na PFC é proporcional à evasão verificada nas oficinas, que começam com 20 a 30 mulheres, e terminam com um grupo de dez a 15.

A baixa escolaridade não é considerada um problema para as organizadoras do curso, que afirmam buscar dinâmicas que possibilitem a participação de todas as pessoas, inclusive analfabetas; situações raras, mas quando ocorrem, está prevista a ajuda mútua entre as participantes.

As educadoras avaliam que o projeto tem conquistado a confiança tanto das internas quanto dos funcionários das unidades. Em relação às mulheres, afirmam preocupar-se em, desde o primeiro encontro, informar tratar-se de um projeto de uma ONG, portanto, não é relacionada à administração da prisão, não trará nenhum benefício em relação à pena, ou outro, além da possibilidade de discussões e reflexões.

Ao final do ciclo de oficinas, as mulheres recebem um certificado com o endereço e o telefone do ITTC e o convite para entrarem em contato quando conquistarem a liberdade. $F . e$ $P$. contam que muitas telefonam ou as procuram pessoalmente, para contar sobre a retomada de suas vidas ou pedir ajuda: "Saem de uma hora pra outra, não sabem como se virar, e buscam orientação", justificam.

Em relação aos funcionárias/os, afirmam que no início havia certa desconfiança, como se suspeitassem que as oficinas fossem espaços para "falar mal deles", e também reclamavam por não haver atividades destinadas a elas/es. O ITTC propôs a constituição de um grupo para a realização de oficinas com as agentes, mas não foi possível pela falta de disponibilidade de horários dos profissionais. A alternativa encontrada foi apresentar o projeto durante o processo de capacitação de agentes penitenciários, realizado na Escola de Administração Penitenciária, por ocasião da contratação de novos agentes.

As educadoras afirmam que o fato de o projeto estar se tornando conhecido nas unidades tem contribuído para amenizar a resistência dos agentes, mas ainda enfrentam problemas do cotidiano prisional, como serem impedidas de entrar com material nas oficinas, sob a alegação de não terem enviado ofício com antecedência.

São limites impostos pela dinâmica da prisão, que se manifesta assim diretamente, mas também por uma inércia silenciosa, que impede a ação, sem, contudo, explicitar que é contrária a ela. Um exemplo foi a iniciativa das mulheres de, com base nas reflexões, buscar "fazer alguma coisa" para melhorar o dia a dia na penitenciária. Discutiram algumas possibilidades de atuação, considerando as condições da unidade, e decidiram elaborar um projeto que viabilizasse a cobertura do pátio, local onde recebem as visitas, na chuva ou no sol. 
Concluíram que poderiam, elas mesmas, fazer a cobertura, utilizando as garrafas "pet" que eram trazidas com suco e refrigerante pelas visitas, e que iam para o lixo. A decisão foi inspirada em uma reportagem veiculada na televisão sobre o tema, e as mulheres ponderaram que, além de ser uma forma econômica - não geraria despesas para a unidade -, também contribuiriam com a reciclagem do lixo.

Assim, a equipe do ITTC foi incumbida de fazer a pesquisa que trouxesse os detalhes para a ação, e as mulheres concordaram em realizar as tarefas envolvidas. O projeto não se concretizou pelas dificuldades impostas pela dinâmica interna da unidade - não foi disponibilizado local para o trabalho, nem tempo, foram apresentados obstáculos burocráticos, etc., etc. Diante dos entraves colocados, o grupo se desarticulou, e a ideia se perdeu. Posteriormente a cobertura do pátio foi feita graças a uma doação de recursos "mas não é de garrafa 'pet' nem feita por elas", destaca $F$.

Apesar dos limites e frustrações, as educadoras apontam algumas alterações nas relações entre as internas, estimuladas não só pelo conteúdo das oficinas, mas por sua dinâmica de propiciar, e estimular, a escuta e a fala.

\footnotetext{
"Elas apontam que passaram a cumprimentar pessoas do grupo no corredor, coisa que não faziam, pessoas com quem elas podem conversar, e reconhecem no grupo a possibilidade de contar coisas delas sem se sentirem ameaçadas. No sentido de poder se expor sem parecer ridícula, fraca, ou ter que manter uma posição de durona o tempo todo. De repente, aquela que é mais durona conta uma coisa que emociona, e ninguém faz chacota, as pessoas acolhem. E a gente imagina que isso vai tomando uma proporção que é maior do que o grupo em si, mas nas relações que elas vão estabelecendo entre elas", explica $P$.
}

Um aspecto peculiar na atuação do ITTC é a conciliação entre o atendimento direto à população carcerária por meio da realização de atividades educativas, e a defesa de direitos do grupo.

São duas frentes que colocam a instituição em posições diferentes diante do Estado. Embora a realização da atividade não coloque o ITTC na condição de "contratada" pelo governo estadual, responsável pela administração penitenciária ou da direção das unidades, a concretização do trabalho depende da permissão desta última instância.

Ao mesmo tempo, a instituição foi formada para defender e promover os direitos da população carcerária. O ITTC foi constituído em 1997 por um grupo de ativistas do campo dos direitos humanos, com o objetivo de garantir os direitos de cidadania "à população excluída - o povo da rua e outros grupos" informa S., uma das fundadoras e atual dirigente da organização. Sem estrutura garantida para o trabalho e em função da experiência anterior dos 
integrantes em atuar no sistema prisional, a organização restringiu seu foco à população carcerária.

No início, foram realizadas iniciativas em unidades masculinas e femininas. Na masculina, houve um trabalho de constituição de horta comunitária, incentivo a trabalhos manuais e sensibilização aos cuidados e aproximação com os filhos. Especificamente para o público feminino, já em 1997 foi produzida a publicação "Manual dos direitos das presas", revista a atualizada em 2001, contendo informações sobre direitos como amamentação, visitas, visitas íntimas, remição de pena, trabalho, assistência jurídica e outros.

Também em 2001, em razão da falta de financiamento, o ITTC fez um novo recorte no seu trabalho, dedicando-se exclusivamente à atuação em unidades femininas. Naquele mesmo ano, firmou um protocolo com a Secretaria de Administração Penitenciária (SAP) para o desenvolvimento de atividades específicas com presas estrangeiras.

Em 2007, juntamente com outras organizações da sociedade civil, o ITTC apresentou à Corte Interamericana de Direitos Humanos um dossiê com denúncias sobre violações dos direitos da população feminina encarcerada ${ }^{83}$. Suas dirigentes são reconhecidas ativistas de defesa dos direitos humanos em geral e da população carcerária, em particular.

As educadoras sintetizam o desafio: "não fazer vista grossa [para as violações], mas sem que essas denúncias acabem impossibilitando que a gente consiga entrar lá”. Para tanto, estabeleceram alguns procedimentos. O primeiro deles é garantir o sigilo dos "desabafos" feitos durante as oficinas. Uma violação só se torna denúncia se a vítima expressar este desejo. Caso isto não aconteça, as educadoras buscam dialogar com a direção da unidade, sem precisar diretamente as pessoas envolvidas. Diante de uma violação, o grupo das oficinas decide as medidas adequadas - denunciar ao Ministério Público, encaminhar para conselhos de defesa de direitos humanos ou buscar diálogo com a direção da unidade são algumas possibilidades.

$F$. e $P$. lembram do caso de uma mulher que deixou de frequentar as oficinas. Perguntaram para as colegas, e uma delas contou que a moça estava doente. Grávida, tinha sofrido uma forte hemorragia e não tinha sido encaminhada para o atendimento médico adequado, ficando na cela, com febre. A colega que contou não podia ser identificada, uma vez que a situação traduzia a omissão das funcionárias e a precariedade do atendimento médico da unidade. A solução encontrada foi de as educadoras procurarem a direção e, com muita delicadeza, perguntar sobre a moça, pedir informações e para vê-la. Então, foram

${ }^{83}$ Cf.: CEJIL e outros (2007). 
tomadas as devidas providências - tratava-se de um aborto, e a mãe ficou mais de 40 dias com o feto morto no ventre.

F. e P. consideram esta a postura possível, mas não ideal, por incidir sobre casos particulares, sem alterar o funcionamento do sistema em geral.

\footnotetext{
"Essa mulher conseguiu atendimento, ela foi encaminhada, ela foi para o hospital. Agora... e as outras? E as outras? Então por isso que a gente fala que não é uma denúncia ideal, porque a gente poderia estar fazendo muito mais por mulheres que estejam passando por situação parecida, e às vezes a gente não chega porque não estão participando dos grupos", refletem as educadoras.
}

F. e P. concordam que as intervenções do ITTC, por vezes, dificultam o trabalho na unidade: "às vezes a gente associa: demos uma cutucada ali, naquele caso, e, de repente, num dia, não deu pra entrar, está mais difícil... aí dá um tempinho pra própria unidade, pra direção, pra baixar a poeira... depois retoma todo o contato, começa a conseguir entrar de novo com mais tranquilidade."

$\mathrm{Na}$ avaliação das educadoras, a organização das oficinas não reduz sua independência do Estado, ao contrário, legitima sua ação na defesa de direitos:

\footnotetext{
“A gente vê muito que se fala de uma realidade distante ou contada. Ir lá, vivenciar, ouvir as histórias dessas mulheres, ouvir as histórias dos agentes, ver um pouco como funciona o dia a dia, o cotidiano dessas mulheres... Ter essa apropriação contribui para denunciar, contribui para ter propriedade de falar, de ir a um debate, de colocar essas questões para debater", afirmam.
}

Por fim, as educadoras afirmam que sua aproximação com o cotidiano da prisão tem levado à reflexão sobre o papel das/os agentes de segurança. Não apenas na perspectiva de representantes do Estado, ou violadores de direitos, mas de seres humanos que são parte de um sistema e enfrentam dificuldades variadas. "A gente vem discutindo bastante com os profissionais que atuam lá dentro, que também possam ser olhados na dificuldade de realizar esse trabalho... o quanto os profissionais também ficam aí nesse meio, convivendo com todo esse sofrimento".

\subsubsection{Projeto Leitura Livre/ Leitura Ativa}

O projeto "Leitura Livre/Leitura Ativa", que no momento da pesquisa de campo era desenvolvido pela Fundação Escola de Sociologia e Política (Fesp), foi criado em 2003, como 
parte do Trabalho de Conclusão de Curso (TCC) de dois estudantes de biblioteconomia e inicialmente chamava-se "Leitura Livre". Posteriormente, a instituição de ensino decidiu dar continuidade à iniciativa, contratou os estudantes, já graduados, que atualmente realizam encontros de leituras em três unidades prisionais de São Paulo - duas femininas, de regimes fechado e semiaberto; e uma masculina, de regime semiaberto. No processo de institucionalização do projeto, o nome foi alterado para permitir o registro, pois já existia outro trabalho com o mesmo nome.

G., um dos idealizadores do projeto, conta que na unidade de Franco da Rocha encontrou um acervo bastante interessante, com obras clássicas da literatura brasileira e estrangeira, mas a biblioteca não era frequentada. O educador informa que o funcionamento das bibliotecas varia entre as unidades. Há bibliotecas abertas, que podem ser frequentadas pelos internos, outras fechadas, nas quais o acesso aos livros é feito por meio de uma lista que contém a relação do acervo, que o interno deve usar para escolher o livro desejado.

De maneira geral, G. considera que as bibliotecas são espaços que estão constantemente sob suspeita, vigilância por parte da segurança, para evitar que se transformem em esconderijo de armas, por exemplo ${ }^{84}$. E as rígidas regras da segurança terminam por desestimular o contato com os livros, mesmo nas bibliotecas abertas. "Passa por todo aquele processo de autorização para poder pegar, e isso já desestimula, porque tem que descer do pavilhão, pedir autorização, depender do agente para poder chegar. Tem um monte de coisas que contribuem para que não vá pegar o livro", explica.

Em geral, as bibliotecas estão inseridas no espaço da escola, então, diante das dificuldades relatadas, na prática somente as pessoas que participam das atividades naquele espaço têm acesso aos livros.

$\mathrm{Na} \mathrm{PFC}$, os encontros do projeto "Leitura Ativa" eram realizados no espaço da escola, onde também fica a biblioteca, o que facilitava o trabalho, uma vez que o objetivo do projeto é estimular reflexões com base na leitura de obras literárias e letras de músicas, em encontros semanais que duram cerca de duas horas.

\footnotetext{
"A proposta inicial foi fazer com que as reeducandas começassem a sentir o gosto pela leitura, a desenvolver o hábito de leitura. Utilizei técnicas que aprendi na faculdade, como mediador de leitura, e fui me aproximando. Então, percebi que tinha um fosso maior, que se eu fosse falar só de literatura, não iria resolver nada, porque o problema era maior. Comecei a trabalhar coisas pontuais, como sexualidade, amor, perdão, saudades e filhos, e com textos menores", informa G..
}

\footnotetext{
${ }^{84} \mathrm{~W}$. relata os transtornos ocasionados em uma unidade quando uma faca foi encontrada na biblioteca.
} 
O número de participantes era bastante variado, e a proposta do trabalho incluiu não haver qualquer tipo de controle de presença. No momento da entrevista, cerca de 30 mulheres estavam inscritas. As pessoas eram convidadas a sentarem em círculos "para quebrar a hierarquia" e havia a preocupação em deixar claro que a participação era absolutamente voluntária. Para o educador, esta estratégia estimulou a confiança do grupo:

Toda vez que era feito um questionamento, era aberto, sem certo ou errado. A ideia era dar voz para as meninas. Daí, fui descobrindo um monte de coisas legais, como a dificuldade de expressar sentimentos, falar do passado, ou até mesmo de vislumbrar o futuro, e também essa lacuna que o Estado deixa no atendimento, como a carência de políticas públicas voltadas para o regresso do reeducando.

O educador lembra que, no início do trabalho, os encontros eram bastante vazios; depois, as pessoas foram chegando e ficando. Na PFC, uma forma de despertar o interesse do público e tornar o ambiente mais agradável foi a utilização de incensos durante a aula, que também eram entregues às participantes. Mas funcionários da unidade "sugeriram" que o produto não fosse mais utilizado nem dado às pessoas, porque estavam sendo utilizados nas celas para "disfarçar" o cheiro exalado dos cigarros de maconha.

A divulgação do projeto era feita por meio de cartazes, afixados nos refeitórios pela equipe da escola da unidade, que também se encarrega de receber as inscrições. $W$. não acredita que existia qualquer seleção prévia por parte dos funcionários da unidade, baseada em critérios disciplinares.

Para G., a resistência dos funcionários em relação às atividades educativas está relacionada ao "trabalho" que elas geram: "Eu não vou generalizar, mas o sistema prisional não gosta dessas atividades na prisão porque demanda trabalho. Para eles, pra elas irem até minha sala, tem que ter alguém olhando, então é legal se não for, né?’.

E., egressa do sistema prisional paulista, onde ficou por aproximadamente sete anos, tendo concluído o ensino médio por meio dos exames de certificação e participado de várias atividades ofertadas ${ }^{85}$, inclusive do "Leitura Ativa", relata que a maior dificuldade é chegar até a escola.

"Dentro do sistema, você necessita de um funcionário para te acompanhar, se não
tiver nenhum funcionário para estar ali na escola, você não pode estudar, se tem
reunião deles, não tem aula, e é sempre assim. A gente tem poucas aulas durante o

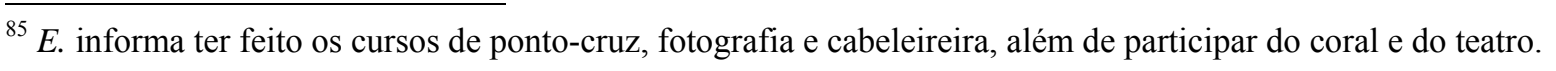


ano. Eu penso assim: a unidade deveria ter um trabalho mais sério, para as pessoas estudarem todos os dias, para ter mais frequência e para as pessoas aprenderem mais. Às vezes é um ano, mas quando você for olhar, durante esse ano você só estudou seis meses, por falta de funcionários, às vezes", diz $E$.

Também tem a desqualificação da população: "Você vai dar aula de literatura para as presas por quê? Por que presa vai ler? Você está dando aula para essas meninas, e elas vão roubar sua casa, e matar sua mãe. Já aconteceu de me segurarem duas horas na porta", lembra G. Quem? Quem diz?

Uma forma encontrada pelo educador para superar a resistência foi buscar envolver os funcionários, apresentando o material que seria trabalhado com as alunas e oferecendo para que levassem também para suas casas. Esta atitude "inclusiva", na avaliação de G., reduziu as resistências.

Contudo, houve dificuldades de outra natureza. A incompatibilidade de horários entre os encontros de leitura e as oficinas de trabalho foi uma delas. A outra, foi a falta de integração entre as atividades, e $G$. afirma não ter havido qualquer tipo de iniciativa no sentido de tentar articular as diversas ações realizadas no mesmo espaço - a escola -, uma tarefa que ele atribui à agência do Estado oficialmente responsável pelas atividades de educação nas prisões, a Funap. "Fica meio solto... eu faço um trabalho de literatura, tem um outro que faz um trabalho de teatro, e a gente podia fazer uma coisa mais em conjunto. Isso me incomoda, e é isso que me pega um pouco na atuação da Funap."

G. considera difícil mensurar o alcance do sentido do projeto para a vida das pessoas envolvidas. $\mathrm{O}$ que percebeu foram algumas mudanças de comportamento, sutis, difíceis de serem apreendidas. Por exemplo, a tentativa de usar o diálogo para buscar a resolução de conflitos, inclusive reconhecendo atitudes acertadas em outras pessoas, mesmo quando contrariavam seus interesses pessoais.

O vínculo estabelecido entre o educador e as mulheres muitas vezes extrapola os muros da prisão e, quando em liberdade, elas buscam contato, seja para contar da sua vida algumas ligam para dizer que estão trabalhando, ou estudando, outras informam que voltaram a roubar e fazer programa -, ou pedir orientação, sobretudo sobre serviços públicos, atualização de documentos.

G. conta que aprendeu muito com as mulheres do grupo, e destaca que entre os conhecimentos adquiridos, está o exercício da solidariedade: "tenho visto aqui exemplos de solidariedade que não vi na igreja." 
Esta entrevista com G. foi realizada em novembro de 2008. Em junho de 2009, novo encontro com o educador revelou que a Fesp, em razão de mudanças na gestão, havia decidido encerrar o projeto "Leitura Ativa". G. estava desempregado, mas tentava desenvolver o trabalho por meio da atuação na Pastoral Carcerária.

\subsubsection{Grupo de Diálogo Universidade Cárcere e Comunidade (GDUCC)}

O projeto "Grupo de Diálogo Universidade Cárcere e Comunidade" (GDUCC) é desenvolvido por estudantes da Faculdade de Direito da Universidade de São Paulo (USP), sob a coordenação do professor Alvino Augusto de Sá, que liderou a iniciativa de constituição do primeiro grupo em 2006. É definido como um grupo oficial do departamento de Direito Penal da Faculdade de Direito da USP e, no final de 2009, houve solicitação para reconhecimento dos créditos de extensão, o que significa maior grau de formalidade.

A iniciativa é desenvolvida na Penitenciária José Parada Neto, que tem capacidade para 804 pessoas e abriga 1.051 homens. O objetivo é assim definido por Braga (2007): “estreitar distância universidade - cárcere, partindo do conceito de reintegração social de Alessandro Baratta, segundo o qual a reintegração é uma 'via de mão dupla', na qual tanto o preso quanto a sociedade têm responsabilidade por essa reaproximação ${ }^{86}$."

Essa aproximação é feita por meio de grupos de diálogos, formados por universitários e presos, que se reúnem em encontros semanais, para discutir temas diversos, ao longo de um semestre. A escolha dos temas pelos dois segmentos, de maneira alternada - uma semana o grupo da academia define e prepara o encontro, na outra, o grupo dos presos.

$M$. destaca que o grupo de internos fez um grande esforço para preparar os encontros, pois não podiam reunir-se fora do espaço do GDUCC. Ainda assim, adotavam a mesma prática dos universitários, tanto no cuidado de organização das dinâmicas quanto no esforço de sistematizar os debates. Então, da mesma forma que os universitários, os internos também tinham um relator, responsável pelas anotações. A coordenação do GDUCC pretende organizar uma publicação com textos dos dois grupos, como parte do trabalho de trazer a prisão para fora de seus muros.

O grupo dos universitários é, até hoje, constituído por estudantes de graduação de diversas faculdades, não se restringindo ao campo do Direito. Há estudantes de Psicologia,

\footnotetext{
${ }^{86}$ Diferentemente das chamadas ideologias "res" (ressocialização, reeducação), pelas quais cabia ao individuo readequar-se valorativamente como condição de seu aceite pela sociedade.
} 
Serviço Social, Ciências Sociais, entre outros. A única exigência é que tenham, pelo menos, $30 \%$ de frequência no período preparatório, que tem duração de um semestre e consiste em encontros para leitura e debate de obras sobre o sistema prisional.

M., uma das coordenadoras do grupo, ressalta que a principal dificuldade é a rotatividade do grupo - ela é a única pessoa que permaneceu desde o princípio, em 2006. Os encontros para formação teórica dos estudantes chegam a reunir 50 pessoas, porém, após as primeiras reuniões na prisão, muitos desistem. "Este é o problema: as pessoas são movidas pela curiosidade [a maioria nunca entrou na prisão], e não com o compromisso com o trabalho", pondera.

Já para a constituição do grupo dos presos, $M$. diz que havia o critério de priorizar os internos que não estivessem participando de nenhuma outra atividade, mas este não foi efetivado porque a seleção ficava sob a responsabilidade dos funcionários da unidade. “Apesar de a gente pedir determinado perfil, para priorizar o preso que está mais aprisionado, mais do fundão, acabam vindo os presos que já estão na escola, que já estão no trabalho, que já têm uma inserção e que, muitas vezes, circulam no lado da educação, e vários que estão envolvidos com a facção criminosa também.”

O GDUCC realiza seus encontros no espaço da escola, ocupa as duas salas de aula existentes, e integram o grupo os presos que participam das demais atividades da escola, inclusive os monitores sentenciados que atuam na preparação para os exames supletivos, o que significa que os encontros do GDUCC provocam a suspensão das demais atividades naquele período.

M. avalia que esta seleção, de os mesmos participarem de tudo, tem múltiplas razões. A primeira, diz respeito à organização interna da unidade: daria mais trabalho locomover um número maior de presos, o que envolveria um número maior de funcionários nem sempre disponível. Outra razão é o grau de "assimilação" dos presos em relação ao sistema. O grupo que participava de tudo, à época da pesquisa, era constituído por pessoas que estavam havia mais tempo na prisão, assimilaram suas regras de comportamento e, portanto, sabiam se comportar de acordo com elas, e, em geral, estavam mais próximos de alcançar a liberdade, o que era um estímulo à participação de atividades que os aproximassem do mundo "de fora".

Notou-se, nesse grupo, um grande número de pessoas evangélicas, convertidas na prisão. Também a disposição espacial demarcava este agrupamento. Os pavilhões mais próximos à área da administração e da escola eram ocupados pelo grupo dos já incluídos na dinâmica do sistema. No pavilhão dos fundos, longe das atividades disciplinares, estavam 
aqueles com penas mais altas, considerados mais perigosos, que ficarão mais tempo na prisão e ainda não se adaptaram às regras da instituição.

No início dos encontros, as relações de poder já estabelecidas entre os presos tendiam a influenciar a participação, e apenas alguns, as lideranças, falavam. No transcorrer do trabalho, M. avaliou que os demais iam se sentindo mais seguros para se expressar. A livre expressão, tanto dos universitários quanto dos presos, é o pressuposto básico do GDUCC; não se trata de transmitir informações, trata-se mesmo de confrontar diferentes perspectivas, opiniões e reflexões sobre temas variados.

Apesar desse pressuposto, $M$. avalia que os presos, muitas vezes, falam o que pensam que os universitários consideram correto e apropriado. Esta também foi a impressão deixada com o acompanhamento de um dos encontros, durante o trabalho de campo.

Naquele dia, 24/9/08, participaram estudantes de Direito e Psicologia, além de aproximadamente 20 internos com idades variadas. $\mathrm{O}$ acordo feito para participar do encontro era não fazer nenhum tipo de anotação durante a reunião. O tema em debate era "A Prisão" e, na conversa, os estudantes argumentavam que a prisão é ineficiente e injusta, feita apenas para as pessoas socialmente vulneráveis. E os internos davam como contra-argumento que era justo estarem ali, pois de fato tinham "errado" e tinham que pagar.

Chamou a atenção a desigualdade da situação - estudantes de classe média (assim se definiam), da universidade pública (reservada para a elite), todos brancos, desqualificando e criticando a prisão. E os presos, pobres, muitos negros, jovens, afirmando que a prisão estava sendo uma oportunidade de aprendizado, sobretudo pela conversão às igrejas evangélicas. Foram vários os relatos de "encontro com Jesus".

Era aniversário de um dos rapazes, jovem negro, A., que completava 23 anos. Ele nos presenteou com um rap de louvor a Cristo, e depois cantamos "Parabéns"; nos ofereceram café, e a equipe do GDUCC teve que sair correndo - literalmente -, pois seu horário tinha acabado. Eu poderia ficar até o final do expediente, às $17 \mathrm{~h} 30$.

M. avalia que o trabalho do GDUCC tem reduzida possibilidade de alterar a vida no cárcere, as relações entre as pessoas ou as dinâmicas do funcionamento do sistema. Pondera que são poucas as pessoas que participam e que ainda não conseguiram envolver os agentes de segurança no trabalho - uma dimensão prevista. No entanto, relata que os participantes contam que as dinâmicas e discussões do grupo são tema de conversas entre eles e, algumas vezes, com suas famílias, nos dias de visita. Para M., no entanto, o maior ganho é a possibilidade de interação entre os próprios presos ao reunir pessoas de diferentes pavilhões que não se conheciam - dentro dos limites das disposições espaciais, já explicitados 
anteriormente - e o embate de ideias, a possibilidade de divergir, discordar de outras pessoas - de dentro e de fora - por meio do diálogo.

Também há a movimentação, ainda que pequena, causada pela presença de pessoas "de fora" ao ambiente prisional. Esta presença, consentida, mas estranha e controlada, é considerada como positiva, porque a possibilidade do encontro com os presos traz a eles bemestar, e eles dizem que durante os encontros é como se não estivessem presos.

O fato de serem universitários desperta curiosidade em relação a sua intencionalidade: por que estariam gastando seu tempo para irem ali conversar com presos? No início, conta $M$, a principal hipótese é que estariam ali para ensinar alguma coisa, mas no decorrer do trabalho percebem que a ideia do grupo é justamente o contato, contato este que permitiria aos de fora conhecer o cárcere, e os presos, confrontar suas percepções com este grupo.

S., havia, então, 13 anos no sistema penitenciário, em setembro de 2008 participava do GDUCC pela segunda vez e das aulas de preparação para o exame supletivo do ensino médio. Informou que a área da educação já esteve melhor, com mais cursos, mas naquele momento não havia nada além do grupo de diálogo e das aulas preparatórias para os exames. O curso de informática deixou de acontecer porque o equipamento está quebrado e também foi extinta a aula de pintura. Sobre o GDUCC, tem avaliação muito similar a de M.:

\begin{abstract}
Muito diálogo. Conhecemos pessoas novas, conversamos sobre lá fora, ele nos traz novidades de lá para cá. Estamos aprendendo com eles, e vice-versa. É uma área apenas de diálogo, nos faz bem conversar [...] Isso é bom, em termos da nossa vivência interna, passamos a conhecer um pouco mais de cada um deles, e eles a nos conhecer também, isso é muito bom, aproxima a pessoa, nos tornamos amigos. (Retornou ao grupo) porque vi que gosto de conversar, e não vejo outra oportunidade fora dali. Está sendo um prazer fazer novamente, conhecer pessoas novas, ver o que elas pensam, para quebrar essa barreira e vir aqui dentro. Isso me fascina, fico curioso em saber o que se passa na cabeça deles, em vir aqui na penitenciária para ver os presos, e estar do nosso lado conversando conosco.
\end{abstract}

$R$, no sistema prisional havia quatro anos, concluiu o ensino médio na prisão e também cursou a distância "Administração de micro e pequenas empresas". No momento da entrevista, atuava como monitor de um curso de idioma. Tinha participado do GDUCC no ano anterior e opinou sobre a iniciativa:

Eu classifico o GDUCC como uma troca, eles aprendem conosco o que se passa no sistema prisional, o que se passa na cabeça do reeducando, o que se passa na vida interna dele, o que o vislumbra quando voltar para fora; e nós aprendemos com o pessoal do GDUCC, eles nos trazem atividades, tem muita gente aqui dentro que está desatualizada, mesmo acompanhando pela televisão e jornal. O GDUCC traz as noticias de fora, as novidades, nos traz outra maneira de ver a vida, até conselho 
alguns deles nos dão, 'olha, quando voltar para fora, não vai entrar no mundo do crime, vai estudar, vai se formar', de certa forma há uma troca. $(R$.$) .$

Houve, por parte de alguns presos, a cobrança para que o GDUCC "fizesse mais por eles" em relação à assistência jurídica e a ações concretas de reintegração quando alcançassem a liberdade. M. diz ter explicitado que estas são atribuições do Estado.

$M$. admite que o projeto provoca mais impacto no grupo de universitários, que são levados a conhecer o ambiente prisional - muitos advogados passam pela faculdade sem conhecer a prisão -, desfazendo preconceitos e mitos e levando novas percepções também para suas famílias: “eu acho que isso reverbera de alguma forma, meu filho está indo lá, e está voltando vivo para casa."

Em relação aos agentes, $M$. conta que há, por um lado, curiosidade quanto ao conteúdo das discussões, o que leva alguns a ficarem "espiando" pela porta. $M$. convidou um deles para participar, "porque o ideal seria envolver os funcionários, os presos, os acadêmicos, diretores, juízes e etc.”, mas ele se recusou e justificou, alegando incompatibilidade entre participar de uma conversa com presos "o que pressupõe uma relação de simetria" e o cumprimento de suas funções, que requer o exercício da autoridade. "Ele achava que havia uma contradição entre se expor, mostrar um pouco da individualidade, e manter a distância que precisa para exercer o trabalho dele." 87

De outro lado, há a necessidade de afirmar a sua autoridade perante a equipe do GDUCC, seja disputando a garantia de sua segurança com os presos - "mas a gente sabe que quem garante a nossa segurança e permanência ali são os presos", diz M. - ou mudando constantemente as regras de ingresso: às vezes, ocorre uma revista, outras, não; em um dia, podem deixar o carro no pátio externo, no outro, não.

Por fim, $M$. também percebe a queixa dos funcionários sobre a atenção dispensada aos presos, e não a eles, que as atividades representam. Esta é uma preocupação do GDUCC, mas há a indisponibilidade de horários dos funcionários para a organização de grupos de diálogos exclusivos a eles.

Se do lado dos funcionários há reclamações, o mesmo não acontece com os presos. $M$. afirma que, ao contrário do que os próprios universitários esperavam, durante os encontros não surgem denúncias de violações de direitos ou queixas sobre as condições de vida na penitenciária. A julgar pelas falas dos presos, as condições de vida e de convivência são

\footnotetext{
${ }^{87} M$. afirma que a agente de segurança responsável pelas atividades educativas participou de um dos grupos de diálogo, e foi muito interessante.
} 
bastante satisfatórias para os presos, pelo menos para o grupo que participa do grupo de diálogo.

O GDUCC guarda algumas peculiaridades em relação às demais iniciativas identificadas no campo pesquisado. Um delas é o processo de entrada na unidade, que diferentemente das demais, não se deu por meio do diálogo direto com a direção da unidade, mas, sim, com o departamento de Reintegração Social da SAP. Depois de passar por esta instância, houve a solicitação para a realização do trabalho com a direção da unidade.

Outro diferencial é seu reconhecimento no sistema de execução penal, a ponto de o juiz da Vara responsável ter solicitado para participar dos encontros e, mais recentemente, ter proposto que a experiência fosse levada a outras unidades.

M. diz que a participação do juiz no encontro gerou polêmica, pois os presos queriam aproveitar a oportunidade única de contato, e tratar de seus casos específicos. Mas isto não seria possível, pois fugiria ao objetivo do encontro. Os presos ficaram bastante incomodados com essa presença, sobretudo porque é considerado um juiz "linha dura", que não concede benefícios, e manifestaram o desejo que ele não mais participasse.

Quanto à possibilidade de levar o trabalho a outras unidades, duas questões se impõem: a falta de pessoas e de estrutura para a ampliação do trabalho e, também, a insegurança em relação às possibilidades de realização das ações. Na atual unidade, o grupo organizado que está no comando do presídio é favorável à realização de atividades promovidas por pessoas "de fora". Mas o grupo que comanda a maior parte das unidades do Estado é avesso a presença de "estranhos" no ambiente prisional, então, há o receio por parte do GDUCC de enfrentar problemas que fogem à sua governança.

\subsubsection{Oficinas Prevenção DST/Aids}

As oficinas de prevenção às DST/Aids, promovidas pelo Instituto Diet - Direito, Integração, Educação, \& Terapêutica em Saúde e Cidadania foram realizadas em períodos anteriores a 2008, quando foi feita a pesquisa de campo. Os funcionários da unidade prisional não tinham o registro da data ou os períodos exatos do trabalho, mas forneceram os contatos da instituição.

A atual equipe do Instituto Diet informou que a pessoa responsável pelas oficinas em unidades prisionais havia se desligado da instituição e não havia outra que pudesse informar sobre a experiência. Foi possível localizar esse profissional, que na época, outubro de 2008, 
trabalhava como vendedor em uma grande loja de departamentos no município de Guarulhos. A entrevista foi marcada, mas sucessivamente cancelada.

As informações apresentadas a seguir foram extraídas da página eletrônica da instituição. É também preciso registrar que o Instituto Diet é citado como apoiador de dois boletins informativos produzidos pelos internos, juntamente com outras organizações: o "Sara-me - mudança, reforma íntima e confiança", nas edições de março e abril de 2008; e o "Atalaia de Cristo - informativo cristão", edição de maio de 2008.

O Instituto Diet - Direito, Integração, Educação, \& Terapêutica em Saúde e Cidadania, ONG idealizadora e executora da ação, em sua página eletrônica institucional ${ }^{88}$ informa que se trata de uma ONG (atualmente juridicamente constituída como Organização da Sociedade Civil de Interesse Público - Oscip) formada em 1989, em Guarulhos, município da região metropolitana de São Paulo. Desde o início, foram realizadas atividades de formação e informação sobre prevenção as DST/Aids e atendimento social, jurídico e psicológico a pessoas HIV soropositivas. A sustentabilidade da organização está vinculada, principalmente, a convênios estabelecidos com governos municipais, estadual e federal, em diferentes programas e linhas de financiamento.

\subsubsection{Oficina de Capacitação em Rádio - Universidade Metodista de São Paulo}

Não foi possível localizar os ex-alunos de jornalismo da Universidade Metodista de São Paulo, responsáveis pela instalação de uma rádio na PFC, assim como pela capacitação de internas para a produção de programas ${ }^{89}$.

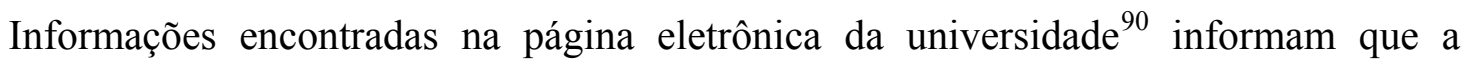
experiência foi desenvolvida como um Trabalho de Conclusão de Curso (TCC) de jornalismo, por oito estudantes no segundo semestre de 2005.

$\mathrm{Na}$ ocasião, 15 mulheres foram capacitadas e, em 5 de setembro de 2005, a rádio foi ao ar, batizada como "Rádio Espaço Livre". A ideia é que essas mulheres multiplicassem a capacitação.

Em 26/9/08, durante uma das visitas de observação à PFC, acompanhei a reestreia da Rádio, que ficou fora do ar por algum tempo, por problemas na aparelhagem. De acordo com

\footnotetext{
${ }^{88}$ Disponível em: <http://www.diet.mk.com.br>. Acesso em: 20 fev. 2009.

${ }^{89}$ Os contatos foram solicitados à administração da Universidade Metodista e também buscados na internet, mas nenhuma das estratégias obteve êxito.

${ }^{90}$ Disponível em: <http://www.metodista.br/noticias/2005/10/28/news_1453>. Acesso em: 18 fev. 2009.
} 
$R$, diretora da escola, os equipamentos foram doação dos estudantes, que dividiram os custos entre si. Quando souberam que os equipamentos não estavam funcionando, os agora exestudantes reuniram-se novamente e viabilizaram o conserto.

Os programas são gravados com antecedência e vão ao ar no horário do almoço, por meio de equipamentos de som instalados nos pavilhões, e os cuidados com a saúde são as principais pautas, além de seleções musicais. O programa de reestreia foi dedicado aos cuidados que devem ser tomados para não se contrair frieiras ou micoses durante o banho na unidade. A produção do programa é feita no espaço da escola, com o apoio dos funcionários que lá trabalham.

Em decorrência da indisponibilidade de horários, não foi possível entrevistar as mulheres envolvidas na realização deste trabalho. No entanto, é necessário registrar o entusiasmo e emoção das mulheres, e também da diretora da escola, na reestreia do programa. Infelizmente, por um problema técnico, o som não chegou a todos os pavilhões.

\subsubsection{Curso de música}

O curso é desenvolvido por B., voluntária vinculada à Igreja Batista, há aproximadamente três anos e meio, com o objetivo de ensinar a ler partituras musicais, "já que a maioria aqui é membro da igreja, já sabem cantar os hinos, mas não têm noção de partituras".

O curso, que dá certificação, não tem duração definida: “depende do aproveitamento deles e da circunstância”. O certificado é emitido pelo Seminário Teológico de Guarulhos, onde $B$. estudou música: "Recebem um documento; a ficha fica arquivada lá no seminário. Amanhã ou depois quando saírem daqui e quiserem terminar o curso, não precisam fazer o básico, que já fizeram aqui dentro”, explica.

B. conta que se aproximou da unidade ao acompanhar os cultos da Igreja Batista ali realizados e, a partir desse contato, se dispôs a realizar o curso de maneira voluntária. Embora a atividade não seja considerada como religiosa, ela explica a relação: "Eu entro aqui como professora de música, mas acabo fazendo outras coisas também, então é como se fosse missionária."

O curso não é restrito aos evangélicos, mas "a maioria que vem procurar já tem conhecimento da palavra, já tem conhecimento da bíblia, eles já têm uma vida reformada, estão arrependidos", informa B., que não participa dos processos de inscrição ou seleção dos alunos e também não tem informação sobre as formas de divulgação. 
Geralmente cada ciclo tem duração de oito ou nove meses, e as turmas começam com dez ou 12 pessoas e terminam com duas ou três. Sobre a evasão, B. informa que para aqueles que desistem, são projetados filmes no horário da aula "para que não fiquem sem fazer nada". Então, enquanto um grupo estuda música, o outro assiste a filmes "com mensagens evangelísticas".

B. classifica como "ótima" sua relação com os estudantes: "eles me respeitam muito, acabamos até criando uma amizade, quando eles saem e eu tenho algum contato, às vezes conhecemos a família, telefonam para perguntar como está". Também em relação aos funcionários diz não encontrar qualquer resistência ao trabalho, ao contrário, "o que eles puderem fazer para ajudar eles fazem. Eles já me conhecem há bastante tempo e sabem que o meu trabalho é esse, eu não tenho dificuldade".

Sobre o significado do curso para os alunos, reflete:

\begin{abstract}
Não sei se eles vão usar o curso como um motivo para fazer alguma coisa, por exemplo, 'não vou voltar para o crime porque fiz um curso de música', isso eu não posso dizer. Mas que o curso faz com que aqueles que cheguem ao final, é porque realmente querem estudar. A música é um negócio enjoado, não é todo mundo que tem paciência, os que conseguem receber certificado, você vê que eles estão interessados mesmo, então quando eles saírem, eles podem até querer continuar o curso.
\end{abstract}

\title{
3.1.8 Curso de injeção eletrônica
}

A iniciativa de promoção do Curso de Injeção Eletrônica é de $J$, voluntário vinculado à religião Espírita, técnico em processamento de dados, que tem como hobby a mecânica de automóveis. Sua aproximação com a prisão aconteceu por meio de um grupo de reflexão espírita, que se reúne na unidade desde 1999.

Depois de quase três anos de trabalho filosófico, J. decidiu propor um curso profissionalizante de mecânica de automóveis, e obteve autorização da diretoria para realizálo pela primeira vez em 2003, e repeti-lo em 2007.

A divulgação do curso contou com a ajuda de dois funcionários da unidade e dos próprios presos: "Lá as informações correm rápido", diz. Houve processo de seleção, pois o curso exige habilidades básicas de leitura e escrita, além de conhecimentos iniciais de eletricidade e mecânica. Cerca de 35 pessoas se inscreveram e 20\% concluíram. Na segunda edição, cerca de 25 se inscreveram e a evasão também foi de aproximadamente $80 \%$. 
Ao comentar o alto índice de evasão, $J$. afirma não haver motivações externas, mas tratar-se de uma decisão pessoal. Sugere ser necessário desenvolver formas de estimular, sensibilizar as pessoas presas a valorizarem atividades de formação. Refletindo sobre a relação entre participar de atividades educativas e praticar uma religião no cárcere, $J$. avalia que as pessoas que buscam religiões têm certa predisposição para participar, buscar novos conhecimentos, assim, também procuram aproveitar as oportunidades de formação.

O fato é que as pessoas que participaram do curso de mecânica de automóveis também frequentavam outras atividades, como aulas de idioma e informática. $J$. explica:

\begin{abstract}
Para entender aquele mundo deles é um pouco complicado. Eles têm necessidade de manter o tempo ocupado com uma ou outra coisa que não seja ficar jogando bola, porque o jogar bola é o dia a dia deles e, fora isso, ficar jogando conversa fora, o que não leva a nada. Então, a grande preocupação é ocupar a cabeça. Quando a pessoa já tem um certo discernimento, ela vai buscar isso. Ou através do curso de injeção eletrônica, ou através do curso de inglês. Ou através de um curso de música. Então, ele quer sair fora do ambiente que ele sente que é prejudicial. Então, ele vai buscar. Às vezes, ele não quer aprender inglês, mas ele vai porque é uma maneira de ele sair fora daquele ambiente, do dia a dia. É complicado.
\end{abstract}

O curso tem duração de três semanas, com aulas em dias alternadas, carga horária de 2,5 horas, no período da tarde e, ao final, os aprovados recebem um certificado assinado por $J$. e pelo diretor da unidade.

$J$. não tem notícia de pessoas que, depois de saírem da unidade, tenham adotado a profissão, mas alguns ex-alunos telefonaram para contar que tinham encaminhado o filho para cursar o Senai, por influência do curso na unidade, baseado no material didático daquela instituição, onde $J$. estudou. E $J$. considera este um resultado positivo, por tratar-se "de uma escola de alto nível".

No início do trabalho, houve dificuldades em entrar com o material necessário ao curso - peças, circuitos, etc. De acordo com J., os funcionários ficaram muito enciumados, e dificultavam o acesso: "Quando eu me deparei com esse problema, eu contornei da seguinte forma: então, vocês formem o grupo, vamos passar pela mesma pré-seleção que os presos passaram, e eu me proponho a dar aula para vocês. O grupo não foi formado, mas pelo menos não tocaram mais nesse assunto de ciúmes", conta.

Em relação aos equipamentos, a maior dificuldade foi colocar um carro dentro da unidade para uma aula prática. A direção autorizou, mas os agentes foram muito resistentes, alegando motivos de segurança. Ao final, a ambulância da unidade foi utilizada na aula, mas apenas por alguns minutos - foi o máximo que se conseguiu. 
Embora $J$. continue disponível para realizar o curso, não há perspectiva de novas edições por falta de apoio. Um entrave é a reprodução da apostila necessária para o acompanhamento do curso. O material tem 120 páginas, e deve distribuído individualmente aos alunos. Na primeira versão do curso, o educador financiou com recursos próprios; na segunda edição, um funcionário comprometeu-se a providenciar as cópias, mas depois de quase um ano de espera, não conseguiu viabilizar. "Eu perguntei qual era o problema e ele: 'Olha, consegui xerocar uma parte, nós mandamos xerocar uma parte num outro setor'. Aí percebi que a coisa é muito complicada", lamenta. $J$. se dispõe a financiar parte do material, mas não tem como arcar com o total dos custos, e "o Estado não consegue me ajudar na confecção dessa apostila”, explica.

$J$. acredita que a participação no curso não gerou apenas conhecimentos técnicos, mas as aulas eram momentos de conversas sobre o mundo do trabalho, posturas profissionais a serem adotadas, importância da constante formação. "Você percebia que a pessoa, conforme ela ia pegando mais conhecimento, ia confiando mais nela. E você via o sonho nascer, sonho que ele queria sair dali entendendo um pouco mais de mecânica, poder se atualizar... Isso ficava bem claro".

\subsection{Algumas reflexões}

\subsubsection{Quem são os atores, o que e como fazem}

As atividades identificadas no campo pesquisado ampliam o quadro de ações construído com base no noticiário dos jornais impressos, apresentado no capítulo anterior.

A "Rádio Livre" caracteriza-se como uma experiência de Educomunicação, campo de atuação e pesquisa que aproxima o uso da produção de meios de comunicação em processos educativos, formais ou não formais ${ }^{91}$. Há experiências de Educomunicação em comunidades $^{92}$, mas também desenvolvidas com grupos específicos, sobretudo de jovens ${ }^{93}$, e também em escolas.

As iniciativas desse campo têm duplo sentido. De um lado, a capacitação de membros de grupos na operação e elaboração de programas de Rádio estimula a produção de

\footnotetext{
${ }^{91}$ Cf.: SOARES, 2000.

${ }^{92}$ PERUZZO, s/d.

${ }^{93}$ Cf.: Revista Viração: <http://www.revistaviracao.com.br>.
} 
conhecimento. De outro, atribui-se a este processo a capacidade de fortalecer vínculos entre os envolvidos, que estimulam o exercício da cidadania ativa ${ }^{94}$. No caso de sua utilização em escolas públicas ${ }^{95}$, por exemplo, havia a expectativa de estimular o envolvimento da comunidade na escola.

As oficinas de prevenção de DST/Aids, realizadas pela ONG Diet, estão inseridas entre as ações educativas realizadas por ONG, financiadas pelo Estado, em todo o Brasil desde o final dos anos 1980, e destinadas a diferentes grupos considerados vulneráveis ao contágio, como profissionais do sexo, usuários de drogas injetáveis e população carcerária ${ }^{96}$. Note-se que também a ONG Colibri iniciou sua atuação no ambiente prisional por meio de um projeto de prevenção a Aids, financiado pelo Ministério da Saúde. Para Gohn (2008, p. 17), a atuação das ONGs neste campo é exemplar da entrada dessas organizações na "agenda das políticas sociais", um dos temas do próximo capítulo deste trabalho.

Já as experiências do "Quem Somos Nós", "Promotoras Legais Populares", GDUCC e "Leitura Ativa" caracterizam-se como ações de Formação para Cidadania, ou em Direitos Humanos, conforme reflexões apresentadas anteriormente neste trabalho.

O curso "Promotoras Legais Populares" (PLP) distingue-se das demais iniciativas por sua aproximação da educação formal no que se refere às rígidas regras de seleção adotadas ${ }^{97}$ mais severas com as mulheres do cárcere do que com as integrantes das edições realizadas nas comunidades de fora da prisão.

A experiência tem foco prioritário na "transferência de conhecimento" (FREIRE, 1996, p. 22) a exemplo das iniciativas de profissionalização (curso de injeção eletrônica) e arte-cultura (curso de música) apresentadas. Nestas iniciativas, o conteúdo a ser transmitido é estabelecido a priori, e os educandos são selecionados para adequar-se a eles. No caso dos cursos de música e injeção eletrônica, há inclusive mecanismos de avaliação para aferir a assimilação dos conteúdos e a certificação para atestá-la.

Diferentemente do curso de profissionalização e arte-educação, e também das demais experiências descritas, o "Promotoras Legais Populares" foi peculiar ao colocar entre seus

\footnotetext{
${ }^{94}$ Ver BENEVIDES, 2004.

${ }^{95}$ Entre 2001 e 2004, em virtude de uma parceria entre a prefeitura de São Paulo e o Núcleo de Comunicação e Educação da USP, estudantes e educadores de escolas de ensino fundamental da rede municipal de ensino foram capacitados a operarem equipamentos de rádio instalados nas escolas. Para garantir a continuidade do projeto "Educom.radio" após a mudança dos gestores, em 2004, a Câmara Municipal de São Paulo votou uma lei que estabelecia sua permanência. As gestões seguintes (2005/2008 e 2009/) alteraram o nome do projeto para "Ondas do Rádio", mas o mantiveram.

${ }^{96}$ A ação de prevenção da Aids nas prisões ganhou projeção pública por meio do trabalho voluntário do médico Dráuzio Varella, amplamente divulgado nos meios de comunicação e tema de obra literária e cinematográfica, intitulada "Estação Carandiru" (VARELLA, 1999).

${ }^{97}$ Cf.: HADDAD, 2009.
} 
objetivos a propagação do conhecimento no ambiente prisional por meio da formação de multiplicadoras, tornando as mulheres envolvidas potenciais educadoras de suas colegas. Este objetivo, que a julgar pela narrativa de $A$., não chegou a se concretizar - pelo menos não formal e institucionalmente -, aproxima a experiência das práticas de educação popular, que tem entre seus princípios a educação entre pares ou entre iguais, membros de uma mesma comunidade ou grupo.

No entanto, o objetivo pode ter sido alcançado, ainda que de forma parcial e informalmente. Em 2004, o acompanhamento da turma de Alfabetização, conduzida por $M B .{ }^{98}$, monitora sentenciada que participou do PLP, constatou que o conhecimento adquirido no curso era disseminado durante as aulas de alfabetização. O tema, e a linguagem, dos direitos e deveres das presas eram bastante recorrentes, indicando ser resultado de reflexões anteriores.

Também na perspectiva da continuidade, os cursos de injeção eletrônica e de música se destacaram pela preocupação em estabelecer vínculos entre os educandos e instituições externas, que podem ser acessadas caso desejem continuar os estudos quando em liberdade.

Em geral, as justificativas para a realização das atividades educativas na prisão são baseadas na ideia da reintegração ou ressocialização. Tanto as pesquisas acadêmicas do campo $^{99}$ quanto os textos publicados pela mídia apresentam esta perspectiva: é quase um jargão que se utiliza, também, para angariar a simpatia da opinião pública a tais iniciativas e ampliar a tolerância em relação à população carcerária. É uma tentativa de instrumentalizar a educação, mostrando, de um lado, que "alguma coisa está sendo feita" para recuperar os presos, e, de outro, que há interesse por parte do grupo em participar, o que os torna mais "humanos" e, portanto, pode gerar alguma identificação com as pessoas honestas.

Entretanto, a observação da realização das ações demonstra que poucas são as chances dessas práticas contribuírem com a organização da vida do lado de fora dos muros, em grande parte, porque elas são destituídas de sentido. E também porque são organizadas de forma bastante precária, sem possibilidade de continuidade, com falta de material, infraestrutura, entre outros. Entre as manifestações da precariedade das ações, está a ausência da formalização dos projetos em termos de objetivos, definição de metodologia, carga horária e certificação: se dão de forma tão fluida que parecem mais destinadas a ocupar o tempo livre, como é o caso dos cursos de idiomas conduzidos, muitas vezes, pelos próprios presos, sem

\footnotetext{
${ }^{98}$ GRACIANO, 2005.

${ }^{99}$ Ver GRACIANO, 2005.
} 
qualquer apoio ou material didático e, também, dos encontros para preparação para os exames supletivos.

Em sentido oposto, as pessoas responsáveis pelos cursos de música e injeção eletrônica desconsideram a especificidade da condição de prisioneiros e guiam sua iniciativa pela noção de direito e dever. Buscam dar aos educandos exatamente o mesmo conteúdo que seria ofertado fora da prisão - tentar levar um carro e insistir para a entrada dos circuitos -, fazem as mesmas cobranças e garantem os mesmo direitos - um certificado que garante o prosseguimento.

O caso da professora de música é ainda mais peculiar, pois foi sua a iniciativa de buscar institucionalidade para o curso, garantir que exista uma ficha de aluno, que fica arquivada para o caso de haver interesse de continuar.

Trata-se de uma orientação que, não estando inserida na concepção da educação em direitos humanos, afirma-se na concepção da educação como um direito humano, no sentido de tentar disponibilizar, na prisão, o mesmo conteúdo dispensado fora dela.

Da parte dos educadores, não existe a intenção de adaptações, simplificações que, em nome do respeito ao perfil do educando, ou à falta de condições, terminam por empobrecer o conhecimento ofertado. J., porém, se recusa ao jogo de faz de- conta, tão comum às atividades ofertadas na prisão: se não há como ter apostila, o curso não acontece, porque é impossível a relação ensino-aprendizagem sem um mínimo de material didático-pedagógico.

Como demonstrado por pesquisas acadêmicas e relatórios de direitos humanos (GRACIANO, 2005, ONOFRE, 2007; CARREIRA, 2009; MUÑOZ, 2009), os números oficiais sobre pessoas estudando e trabalhando nas prisões escondem realidades de situações tão precárias que dificilmente poderiam ser classificadas como atividades educativas, por não atenderem ao princípio da Aceitabilidade, um dos parâmetros adotados pela ONU para analisar as condições da educação em diferentes países.

Esses parâmetros foram formulados pela Relatoria Especial das Nações Unidas para o Direito à Educação, e além da Aceitabilidade, que se relaciona à garantia da qualidade da educação - incluindo programas de estudos, métodos pedagógicos e a qualificação dos professores -, propõe ainda que a verificação de outras três dimensões: "Adaptabilidade requer que as escolas se adaptem às necessidades dos alunos e que a educação corresponda à sua realidade"; "Disponibilidade - a educação gratuita deve estar à disposição de todos"; "Acessibilidade - garantia do acesso à educação pública sem qualquer tipo de discriminação" (TOMASEVSKI, 2001, p. 12-14). 


\subsubsection{Não à escola, sim ao conhecimento}

Se os cursos de injeção eletrônica, música e PLP foram formatados com base em mecanismos que os aproximam, pelo menos na estruturação, da educação formal, "Quem Somos Nós", GDUCC e Leitura Ativa buscam afirmar-se pela negação de adoção desses mecanismos.

As pessoas envolvidas nesses projetos estranharam serem entrevistadas para uma pesquisa que tem como objeto as práticas de educação não formal realizadas pela sociedade civil nas prisões. Frisaram mais de uma vez que suas ações não são de educação, pois não querem "ensinar nada a ninguém", "os encontros não são aulas", "não há hierarquia", "a opinião de todos tem o mesmo valor".

Sem desconsiderar a importância, e abrangência, do debate sobre as concepções de educação escolar que estimulam essas observações, interessa para esta pesquisa registrar que as opções pedagógicas das iniciativas apresentadas inserem-nas no campo da educação popular (FREIRE, 1983; VARGAS, 1998), inclusive e, sobretudo, porque geram conhecimento e, ao mesmo tempo, informações, com base no cotidiano do cárcere. Adotam o que Freire (1996, p. 47) chamou de perspectiva progressista de educação, baseada na ideia de que "ensinar não é transferir conhecimento, mas criar as possibilidades para a sua própria produção ou a sua construção".

Silva e Marques $(2009$, p. 27) alertam para o risco de análises de experiências de educação popular basearem-se no senso comum da afirmação que "a participação gera conhecimento", sem explicitar qual é ele.

Cada uma das iniciativas descritas anteriormente geraria pesquisas específicas sobre o conhecimento construído no cárcere. Neste trabalho, os breves relatos permitem apreender alguns fragmentos da aventura de pessoas que se dispõem a constituir grupos de ensinar e aprender, juntos.

No caso do "Quem Somos Nós", a descrição do sofisticado exemplo da elaboração do projeto da cobertura de garrafa "pet", com todas as etapas deste tipo de trabalho, é bastante explicita quanto às possibilidades de conhecimento produzido.

No GDUCC, ao contrário de M., o interno $E$. não tem dúvida sobre o fato de que estão uns aprendendo com os outros sobre prisão, sobre o funcionamento da sociedade. Tanto assim que há, nos dois grupos, a preocupação do registro de suas discussões, material que pretendem divulgar, fazendo circular as ideias e debates compartilhados, trazendo para fora dos muros um conhecimento que só ali dentro poderia ter sido gerado. 
O "Leitura Ativa" poderia ser classificado como um projeto de estímulo à leitura, como outros que são desenvolvidos e noticiados em diferentes Estados, conforme análise de mídia apresentada no Capítulo 2. No entanto, G. não se limitou a oferecer clássicos da literatura para leitura e discussão. Inverteu a lógica das aulas e propôs que as mulheres conversassem sobre sua vida: a prisão, a família, os amores e, a partir daí, buscou textos mais curtos, respeitando a história irregular de escolarização e falta de familiaridade com o mundo escrito - e músicas que pudessem se relacionar à sua realidade e, com base neles, refletir sobre possibilidades de organização da vida e dos sentimentos. G. apostou no potencial "humanizador" da literatura, como Antonio Candido (2004, p. 144) propõe: "A literatura desenvolve em nós a quota de humanidade na medida em que nos torna mais compreensivos e abertos para a natureza, a sociedade, o semelhante.".

\subsubsection{Incidir sobre o presente}

"Quem somos nós" e "Leitura Ativa" se aproximam na expectativa de que suas ações estimulem as educandas a buscar transformar sua vida. O conhecimento produzido deve orientar ações para mudar suas condições de vida, seja no aspecto emocional ou material - no encontro com a emoção na leitura de um livro ou audição de uma música, ou construindo coberturas de garrafa "pet". O que importa é estimular a crença na sua própria capacidade de conduzir a vida pessoal, e também a "conscientização como um esforço de conhecimento crítico dos obstáculos, vale dizer, de suas razões de ser" (FREIRE, 1996, p. 54).

O autor (1996, p. 54) insistia na necessidade de homens e mulheres se conscientizarem do seu "inacabamento", da sua "incompletude", para que possam se convencer da possibilidade de ir além dele. Este processo é que traz a consciência da presença no mundo e mais, da sua própria, mas também das outras pessoas. Também instiga a busca do conhecimento para buscar a compreensão deste mundo e, mais ainda, as possibilidades de alterá-lo. "[...] apelei para a conscientização não como panaceia, mas como um esforço de conhecimento crítico dos obstáculos, vale dizer, de suas razões de ser."

Para o autor (1996), a consciência em relação ao mundo, aos fatos, aos acontecimentos, é exigência humana e um dos caminhos para colocar em prática a "curiosidade epistemológica" e "fundante na produção do conhecimento".

O processo de elaboração do projeto da cobertura de garrafa "pet" certamente exemplifica, dá concretude às reflexões do autor. Conscientes de que podem atuar para alterar 
o mundo - no caso, resumido à penitenciária --, as mulheres puseram-se a identificar como fazer... e decidiram por uma necessidade absolutamente concreta: proteger-se e às suas visitas da chuva e do sol. Curiosas, buscaram fora a inspiração - um programa de TV que alguém tinha assistido, a solução economicamente viável e... ambientalmente sustentável. Interessante o discurso da proteção ambiental sendo incorporado num lugar onde não há árvores ou animais - exceto ratos e baratas - a serem apreciados; valores de parte da sociedade externa aos muros sendo incorporados, tendo os meios de comunicação como o agente educativo.

Divisão de tarefas executada, pesquisa feita, socializada entre o grupo; tudo pronto para colocar em prática, mas a lógica da prisão impediu a concretização, a finalização do trabalho.

Não foram apresentadas justificativas - nem mesmo a tradicional frase "razões de segurança", tão conhecida dos educadores que atuam nas prisões, foi expressa. O que havia de errado, de inadequado na experiência? O fato de tratar-se de uma ação repleta de sentido é uma explicação bastante razoável.

\subsubsection{A falta de sentido como condição}

Vale a pena recuperar as reflexões de Foucault sobre a natureza da prisão $(1979,1987,2006)$. O autor explica que a prisão deveria ter tido o mesmo êxito, em termos de transformação dos indivíduos, que a escola, os quartéis ou os hospitais, todas instituições formatadas pela inspiração Iluminista do século XVIII. No entanto, no caso das prisões, o "fracasso foi imediato", e logo se percebeu que, longe de ofertar às pessoas presas conhecimentos e condições para viverem dignamente em sociedade, a instituição aprofundava o saber no mundo do crime, produzindo delinquentes (FOUCAULT, 1979, p. 133).

Ocorre que também se percebeu que a produção e a reprodução da delinquência eram úteis à organização social. Em alguns momentos, como mão de obra quase escrava, quando o mercado assim o exigia (RUSCHE; KIRCHHEIMER, 2004) e em outros, para demonstrar a necessidade de garantir poder ilimitado ao Estado para proteger as pessoas honestas contras os grupos perigosos, lembrando que a noção de grupos perigosos é construída historicamente. No Brasil, no final do século XIX e início do XX, o grupo era constituído por ex-escravos e outros desempregados que vagavam pelo meio urbano que então nascia (ADORNO, 1990); em meados do século $\mathrm{XX}$, foram os desempregados, chamados de vagabundos e prostitutas (SOARES e ILGENFRITZ, 2002); durante o período da ditadura militar de 1964 a 1984, 
manteve-se o grupo do período anterior, mas foi dado especial destaque para as pessoas que discordavam do regime autoritário, classificados como comunistas, assim como, na atualidade o foco recai sobre as pessoas envolvidas com drogas, usuários ou traficantes (NASCIMENTO, 2008).

Por fim, para Foucault $(1987,2006)$, a prisão também funcionava, e continua funcionando ${ }^{100}$, principalmente como instituição de sequestro, destinada a tirar de circulação os grupos que não têm lugar na sociedade ou, como define Castel (1997), as pessoas que estão na "zona de desfiliação", caracterizada por duplo processo de desligamento social: ausência de trabalho e isolamento relacional.

Assim, cada país, ou sociedade, tem seus grupos sobrantes, caracterizados por condições socioeconômicas, étnico-raciais; culturais e/ou religiosas (BAUMAN, 1999; CHRISTIE, 1998), variáveis que podem se combinar. Entre os diferentes países, há traços comuns que unem as populações carcerárias - em sua maioria, são pobres, homens e jovens, e há um forte componente étnico-racial, notadamente afrodescendente ${ }^{101}$. Chantraine e Mary (2006) relata que pesquisa realizada no Canadá, buscando analisar a clientela da prisão daquele país entre 1836 e 1913, com dados sobre infração, duração da pena, idade e grupo étnico, concluiu que a "estabilidade da instituição frente ao tempo, na permanência de seus fundamentos como avesso vergonhoso da liberdade e, apesar das mudanças de infrações ou de população, na permanência de sua função de último gestor dos resíduos sociais" (CHANTRAINE, 2006, p. 4).

Em todo caso, para Foucault (1979, p. 133), seja qual for a ênfase da função social da prisão em determinado tempo e lugar, as atividades destinadas aos presos deveriam ser destituídas de sentido. $\mathrm{O}$ autor reflete sobre a necessidade de o trabalho ser inútil, primeiro para afirmar sua virtude e, agora, para garantir a produção da delinquência:

\begin{abstract}
o trabalho penal não é aprendizado deste ou daquele ofício, mas o aprendizado da própria virtude de trabalhar [...] o problema então não era lhes ensinar alguma coisa, mas ao contrário, não lhes ensinar nada para se estar bem seguro de que nada poderão fazer saindo da prisão. O caráter da inutilidade do trabalho penal que está no começo ligado a um projeto preciso, serve agora a uma outra estratégia.
\end{abstract}

As pessimistas reflexões de Foucault (1979, p. 133), formuladas sobre o trabalho nas prisões, são aqui estendidas à educação. De outra forma, como justificar a manutenção dos pequenos entraves, cotidiana e incansavelmente impostos às atividades educativas? No campo

\footnotetext{
${ }^{100}$ Ver: GARLAND, 2008; CHRISTIE, 1998; DE GIORGI, 2006 E BAUMAN, 1999, entre outros.

${ }^{101}$ NASCIMENTO, 2008; CHRISTIE, 1998; BAUMAN 1999; CARREIRA, 2009; MUÑOZ, 2009.
} 
do ensino profissionalizante, porque restringir a oferta aos trabalhos artesanais e raramente propiciar cursos com algum valor no mercado de trabalho ${ }^{102}$ ? O que dizer das proibições inexplicáveis, explicadas quase sempre sobre a enigmática frase "razões de segurança"? São de fato muito curiosas: mesmo com homens e mulheres observando, com as constantes revistas às celas, aparelhos detectores de metais, tudo que pode agregar sentido às atividades é perigoso, coloca em risco a segurança: a presença de um carro, varetinhas de incenso, visitas a bibliotecas, acesso a páginas eletrônicas de conteúdo educativo, para citar exemplos encontrados no campo pesquisado.

Contudo, podem-se ampliar os exemplos se forem consideradas algumas informações obtidas em conversas informais. O cultivo de hortas já foi estimulado pelo ITTC, apresentando resultados interessantes na aproximação com a comunidade e também na elevação da autoestima da população carcerária, justamente por ser uma atividade útil a eles e às crianças da creche beneficiada. Também tem uma interessante dimensão educativa, pois envolve a necessidade de acessar conhecimentos sobre o cuidado e cultivo da terra. Para algumas direções de unidades, trata-se de uma atividade perigosa, em virtude do tamanho da planta. Considera-se que os pés de tomate, por exemplo, podem abalar o sistema de segurança, pois crescem muito e podem ocultar intrusos que venham resgatar os presos.

$\mathrm{O}$ que reforça a ideia da necessidade de garantir a falta de sentido para as atividades é a ausência da busca de alternativas. No caso da horta, por exemplo, se os tomates são perigosos, porque não investir nas batatas, cenouras e toda a legião de verduras? Se não pode haver acesso livre à internet, porque não liberar apenas algumas páginas eletrônicas de caráter educativo? Para cada razão de segurança haveria muitas alternativas, mas elas não são sequer cogitadas, sob pena de parecer contestação. Mas, também, quem contestaria? Quem sairia em defesa da qualidade da educação ofertada? Quem reivindicaria as condições adequadas de ensino-aprendizagem? Quem ousaria questionar a ênfase na segurança, que Garland chama “contenção neutralizante” (2008, p.56).

\footnotetext{
${ }^{102}$ E., egressa do sistema, faz uma análise dos cursos que fez - cabeleireira, estética, manicure, que acontecem uma vez por ano ou a cada dois anos - na penitenciária: “'mente vazia, oficina (do Diabo). Lá dentro você convive com diversas pessoas que foram traficar ou roubar e, como consequência, foram parar naquele lugar, e existem pessoas que estão ali porque gostam, gostam do crime, gostam do dinheiro fácil. [...] esta convivência te leva para baixo, então, se a unidade oferece cursos, já te dá uma direção do que você vai fazer da vida quando sair dali. Eu comecei a trabalhar com ponto-cruz, se eu tivesse que trabalhar na área de artesanato eu trabalharia tranquilamente, a maioria dos cursos lá dentro da penitenciária é com artesanato. A princípio, era para passar o tempo, hoje em dia, se fosse para trabalhar com artesanato, eu trabalharia". Mas E. encontrava-se desempregada no momento da entrevista, tinha procurado a ajuda de $G$. para organizar seus documentos pessoais, e não sabia exatamente como iniciar a busca por emprego.
} 


\subsubsection{Acesso controlado}

As atividades educativas na prisão constituem em privilégio, e não direito. Esta situação é percebida por $M$., do GDUCC, ao constatar que os presos que participam das atividades são aqueles já devidamente inseridos no sistema - pessoas que se converteram às religiões evangélicas ${ }^{103}$ e membros de facções criminosas, em sua maioria. Os demais responsáveis por atividades educativas creem que não se usam critérios de comportamento para a seleção dos participantes. No entanto, tanto a divulgação quanto o registro dos interessados são feitos com a "ajuda" de pessoas de "dentro" do sistema: presas agentes culturais e funcionários foram citados.

Também, não pode ser coincidência o fato de, num ambiente em que a oferta de atividades é restrita - os internos e a interna das duas instituições falam das reduzidas possibilidades, inclusive afirmando que já houve "dias melhores", com mais atividades -, as mesmas pessoas participarem de todas as atividades propostas em diferentes períodos, como demonstram as entrevistas tanto com alguns educadores quanto com as pessoas sentenciadas.

M., do GDUCC, constata que, para facilitar o trabalho dos agentes, participam as pessoas que já estão no ambiente da escola no horário, tanto assim que os encontros para a preparação para os exames supletivos são suspensos, emprestando seus alunos para o grupo de diálogo.

$J$. considera que a opção de participar, ou não, é pessoal, e explica a presença de muitas pessoas convertidas a religiões pela motivação individual - são pessoas que estão em busca de sair do mundo da prisão, mesmo estando presos; então, buscar religiões, cursos ou outra atividade qualquer é parte dessa estratégia.

É uma explicação que não exclui a possibilidade de as atividades educativas integrarem o sistema de privilégios, ao contrário, podem potencializá-lo, conforme demonstram as reflexões de Chantraine $(2006$, p. 79$)$ ao analisar a organização das prisões canadenses, baseando-se na "economia relacional da detenção."

\footnotetext{
103 O papel das religiões evangélicas no sistema prisional tem sido objeto de pesquisas acadêmicas. Também, Carreira (2009), em relatório sobre a educação nas prisões brasileiras, aponta a conversão às religiões evangélicas como forma de proteção, uma vez que este grupo habita celas separadas do restante da população. Conversas informais com dirigentes de unidades prisionais revelam que as celas habitadas por pessoas evangélicas são localizadas em pontos estratégicos das penitenciárias, a fim de ampliar as condições de segurança - em geral, nos pontos de onde se pode ver com maior nitidez os vigias na muralha.
} 
A submissão do acesso a direitos ao sistema de recompensas é denominada por Fisher $^{104}$ (2004 apud CHANTRAINE, 2006, p. 87) de "manuseabilidade dos corpos associada doravante à garantia dos direitos" e por Chantraine (2006) de "relativa garantia de direitos", referindo-se às prisões do Canadá, que viveram o que Garland (2008) denomina "previdenciarismo penal”, caracterizado pela extensão, aos presos, dos direitos garantidos às populações pobres nos países que passaram pelo Estado do Bem-Estar Social.

Certamente não é o caso do Brasil, mas ainda assim, como demonstrado no Capítulo 1, o sistema penitenciário brasileiro incorporou, formalmente, o vocabulário da garantia dos direitos à população carcerária. Com isso, é válida a formulação de Chantraine (2006, p. 88) ao constatar que: "amplos leques de direitos promovidos no interior desse quadro carceráriosecuritário permanecem ainda submetidos e condicionados a esse quadro de segurança, constituindo assim um recurso para a antecipação, a orientação e controle das condutas".

Tomando como exemplo a visita íntima, que segundo Chantraine (2006, p. 88) foi instituída no Canadá em 1980, por demanda de ativistas de direitos humanos, o autor explica:

A análise de seu funcionamento deixa transparecer a existência de "vales" que permitem constituir esse direito em instrumento de governo e integrá-lo ao arsenal tático necessário para a produção da ordem. Com efeito, para além das desigualdades inerentes ao dispositivo, o acesso às visitas íntimas está condicionado ao bom comportamento institucional.

Os "vales-direito", conforme Chantraine (2006, p. 97), são concedidos prioritariamente "aos detentos-líderes, produtores de ordem" (2006, p. 88), e é este arranjo que caracteriza o canadense "sistema bombom", baseado na "instrumentalização intensificada das relações sociais em detenção".

Exemplar na conversão dos direitos em privilégio, como forma de garantir a ordem, é a proibição do acesso à leitura - um direito humano, como propõe Antonio Candido (2005, p. 130-158) - como uma das formas de punição utilizadas nas penitenciárias de "supermáxima segurança”, chamadas "Máxi-Máxi”, em 36 Estados dos EUA. "O confinamento disciplinar é ainda mais sério e dirigido aos presos que cometem infrações dentro da penitenciária. Além das restrições associadas à vigilância estrita, esses internos não têm autorização para qualquer leitura não seja de textos legais" (CHRISTIE, 1998, p. 90).

Chantraine (2006, p. 97) avalia que, neste contexto, a ordem carcerária surge como equilíbrio instável para atender a duas ordens de necessidades. A primeira, dos funcionários

\footnotetext{
${ }^{104}$ FISHER, N. Focault et le droit, de l’hypotèse répressive a l’instrument de gouvernement: le cas de la retention administrative dans la France contemporaine, communication au colloque "La politique vue avec Foucault”. Paris: Sciences-Po, CIR, 2004.
} 
que têm a responsabilidade pela guarda dos detentos e buscam fazer isto evitando problemas, geralmente pela concessão dos privilégios. Em segundo lugar, há a necessidade dos internos de melhorar seu cotidiano e organizar sua vida social, muitas vezes por meio "das lacunas do regulamento, de acordo com um continuum clandestinidade-tolerância.”.

De acordo com Chantraine (2006, p. 98), é com base nessa dupla necessidade que se estrutura um sistema complexo de privilégios, que serve ao mesmo tempo "como ferramenta de pacificação e de estabilização das relações no âmbito da prisão, condição sine qua non para a cooperação dos detentos e para sua participação em sua própria sujeição, e fonte de desigualdades significativas entre detentos.”.

Para funcionar adequadamente, o sistema conta com a participação dos detentos, que assumem a posição de líderes, representantes de seus pares. Estas pessoas assumem o papel de negociadoras, levando demandas dos presos aos funcionários e convencendo os colegas a manterem a ordem, como forma de receberem "bombons" ou privilégios coletivos, como festas, atividades educativas e socioculturais. Dessa forma, sua autoridade depende que as duas partes cumpram os acordos - os detentos evitam provocar tensões internas, os funcionários concedem privilégios coletivos à população carcerária, e individuais aos líderes.

Por esse sistema, os funcionários das prisões tornam-se reféns da boa atuação dos líderes e, simultaneamente, as pessoas presas, sobretudo os líderes, se envolvem pessoalmente na gestão da prisão, tornando seus interesses pessoais reféns dos interesses da instituição na manutenção da ordem. Decorre daí que não há espaço para a contestação da organização da unidade durante os períodos de equilíbrio de funcionamento do sistema.

As reflexões de Chantraine (2006) ajudam a interpretar a observação de $M$. sobre o grande número de líderes de facções participando das atividades e, talvez, sobre a total ausência de críticas à gestão da unidade nos encontros. Também, constituem-se numa perspectiva de análise bastante plausível para um aspecto inusitado das entrevistas com os internos, feitas no interior da unidade.

As duas pessoas entrevistadas demonstraram-se muito preocupadas em elogiar e reconhecer a boa vontade dos funcionários e educadores da Funap na oferta das atividades. Apontados problemas, como o fato de os computadores estarem quebrados havia bastante tempo, os próprios entrevistados apressavam-se em afirmar que a responsabilidade não era dos funcionários ou da Funap. Os elogios chegaram a tal ponto que um deles afirmou que a biblioteca da unidade contém dez mil títulos. Ninguém da unidade pôde confirmar a informação, também não foi possível visitar o local, mas parece pouco provável que a informação corresponda à realidade. 
Certamente os internos têm suas razões para aprovar a organização da vida na unidade. Não se trata de desqualificar sua avaliação, mas chama a atenção a necessidade de defender as iniciativas, quando as perguntas buscavam compreender o significado delas para sua vida pessoal. Mas é impossível não relacionar seu comportamento ao fato de eles terem acessado todas as atividades educativas realizadas na prisão nos últimos três anos e, no momento da entrevista, serem contratados pela Funap como monitores de educação, ao mesmo tempo em que frequentam ou frequentaram o GDUCC.

As reflexões de Onofre (2007, p. 19) sobre o comportamento das pessoas presas diante de perguntas sobre seu cotidiano, em geral, e em relação às atividades ofertadas, em particular, elucida o tema: "Sua sobrevivência depende de sua capacidade de dissimular, mentir e conter-se. Por isso são comuns, em suas falas, avaliações positivas do trabalho, das atividades de que participam e da própria escola"

\subsubsection{Os/as educadores/as e o potencial de controle da educação}

No contexto descrito, dificilmente serão os detentos a reivindicar ações educativas ou mesmo de trabalho. Então, não seria absurdo supor que as pessoas que entram nas unidades prisionais para realizar atividades educativas cumprissem este papel.

Ocorre que, historicamente, a contestação das prisões é feita na perspectiva da defesa da integridade física da população carcerária, o que implica a crítica sobre os maus-tratos, tortura, falta de acesso à alimentação e à saúde (RUSCHE; KIRCHHEIMER, 2004, FOUCAULT, 2006, ALVAREZ, 2006, CHANTRAINE, 2006). Especificamente sobre a educação, apenas muito recentemente, no Brasil, há registros de grupos que demandem os direitos educativos de presos, conforme será demonstrado no capítulo 4.

Da mesma forma, há poucas reflexões dos teóricos do campo prisional sobre o papel dos educadores. Foucault (1988, p. 219) iguala sua atuação à dos sacerdotes na função de contribuir com a individualização e variação na aplicação da pena. $\mathrm{O}$ autor explica que a adoção de recompensas, ou concessão de benefícios, não pode ser gerida pelas instâncias judiciárias, distantes do cotidiano prisional, sem condições de acompanhar o comportamento dos presos. Esta função seria então exercida, com total autonomia, pelas pessoas que ficam próximas à população carcerária: 
Autonomia indispensável, por conseguinte, de pessoal que gere a detenção quando importa individualizar e variar a aplicação da pena: fiscais, um diretor de estabelecimento, um sacerdote ou um professor são mais capazes de exercer essa função corretiva que os detentores do poder penal. (FOUCAULT, 1988, p. 219).

Garland (2008) e Christie (1998), quando fazem referências a professores ou educadores no ambiente prisional, os incluem no grupo dos "trabalhadores sociais", que compreendem também psicólogos e assistentes sociais.

A aproximação entre os campos da educação e da assistência social é discutida na formatação do conceito de Pedagogia Social, ou Educação Social, como demonstrado no Capítulo 1.

Teóricos que refletem sobre a Pedagogia e Educação Social (FICHTNER, 2009; RIBEIRO, 2009; NUÑEZ, 2009) afirmam haver uma contradição inerente a qualquer prática educativa, formal ou não formal, destinada às populações vulneráveis: ao mesmo tempo em que busca contribuir com a superação da condição de vulnerabilidade, intensifica os mecanismos de controle social sobre as pessoas envolvidas.

No mesmo sentido, Adorno (1990, p. 50) salienta que a filantropia privada foi "renovada" no final do século XIX, início dos XX, a fim de dar atenção às pessoas pobres trabalhadores da economia informal, delinquentes, vadios, alienados mentais, prostitutas, crianças abandonadas, velhos - no processo de constituição dos centros urbanos brasileiros, notadamente a cidade de São Paulo, tarefa que o Estado não assumia. "Tratava-se, em verdade, de uma operação delicada: prestar socorro e assistência aos pobres sem que isso se convertesse em direito à pobreza.".

Adorno afirma ainda (1990, p. 50) que a atuação filantrópica apresentou-se como alternativa ao "enclausuramento", única ação do Estado dispensada aos pobres, mas que estava em desacordo com os princípios liberais humanitários, amplamente invocados no período. "A emergência da filantropia higiênica [...] buscou fixar modalidades sui generis de relações hierárquicas entre micropoderes, constituindo a trama do complexo tutelar, introduzindo uma nova arte de administrar a cidade e fazendo com que o Estado se governamentalizasse", salienta o autor, apontando a relação entre a ação filantrópica e a possibilidade de controle sobre esses grupos.

Mesmo considerando motivações vinculadas à solidariedade humana, contribuição com a promoção da justiça social, assistência, parece não haver possibilidade de atuação, no campo da educação, com populações marginalizadas, sem a dimensão do controle. 
O GDUCC, por exemplo, que tem seu foco de atuação na possibilidade de reintegração do preso, portanto, uma perspectiva de futuro, indica ter também a expectativa de alterar o cotidiano dos integrantes do grupo ao vislumbrar, como critério de seleção, a participação daquelas pessoas que não participam de nenhuma outra atividade, que não estão inseridas na organização da prisão, que ainda não compartilham da cultura interna, que não tenham passado pela educação informal amplamente ofertada no cárcere.

De um lado, a busca de pessoas com menor grau de institucionalização é motivada pelo anseio de estabelecer diálogos menos formatados, marcados pela lógica de falar o que o interlocutor espera ouvir ou considera adequado. De outro, há também a expectativa da inclusão na lógica prisional - participar de uma atividade autorizada pela Secretaria de Administração Penitenciária e pela direção da unidade significa, de alguma forma, aderir às normas, portanto, alterar seu comportamento no dia a dia.

Nuñez (2009, p. 252) considera que esta contradição não deve inibir organizações e pessoas de atuarem com educação de grupos marginalizados, desde que o trabalho seja marcado por uma postura interrogativa ante as razões das instituições em estimular o trabalho, admitindo e explicitando que existem "regras do jogo", e também interrogar constantemente a prática profissional, social e educativa; e, por último, contribuir com a construção de redes, de espaços de debates, que possibilitem a geração e a ampliação do conhecimento acerca da realidade que se revela.

Paulo Freire (1996, p. 76), ao analisar a atuação de educadores em espaços de privação de direitos, afirma: “A adaptação a situações negadoras da humanização só pode ser aceita como consequência da experiência dominadora, ou como exercício de resistência, como tática na luta política. Dou a impressão de que aceito hoje a condição de silenciado para bem lutar, quando puder, contra a negação de mim mesmo.”.

O educador não admitia a possibilidade de processos educativos neutros. "Para que a educação fosse neutra era preciso que não houvesse discordância nenhuma entre as pessoas com relação aos modos de vida individual e social, com relação ao estilo político a ser posto em prática, aos valores a serem encarnados" (1996, p. 111).

Então, aceitar o desafio de educar implica a tomada de posicionamento: ou a prática está voltada para manutenção das coisas do mundo como estão, ou se busca a mudança, com base na leitura da realidade e a problematização do futuro, como algo a ser construído a partir das ações no presente. Nesse sentido, Freire (1996, p. 77) ressalta: 
Um dos saberes primeiros, indispensáveis a quem, chegando a favelas ou a realidades marcadas pela traição a nosso direito de ser, pretende que sua presença se vá tornando convivência, que seu estar no contexto vá virando estar com ele, é o saber do futuro como problema e não como inexorabilidade. É o saber da História como possibilidade e não como determinação. $\mathrm{O}$ mundo não é. $\mathrm{O}$ mundo está sendo. Como subjetividade curiosa, inteligente, interferidora na objetividade com que dialeticamente me relaciono, meu papel no mundo não é só o de quem constata o que ocorre mas também o de quem intervém como sujeito de ocorrências. (FREIRE, 1996, p. 77).

Da afirmação de Paulo Freire, pode-se deduzir que a orientação dada por educadores à educação que promovem - mudanças nas condições de vida ou manutenção delas - está diretamente relacionada ao juízo que se faz dos educandos com os quais atuam. Educar para a mudança pressupõe considerar as pessoas do grupo com o qual se vai atuar como "traídas no direito de ser", ou pessoas que tiveram e têm direitos negados.

Christie (1998, p. 65) dispõe sobre duas formas de se considerar os sobrantes da sociedade, ou, como ele define, as pessoas menos úteis e potencialmente mais perigosas, que foram consideradas, ao mesmo tempo, lixo e dinamite por Spitzer (1977): "Elas mostram que nem tudo está como devia no tecido social e, ao mesmo tempo são uma fonte potencial de perturbação". Então, ou essas pessoas são consideradas "perigosas" ou "pobres desajustadas". De qualquer uma das formas, o tratamento não prescinde de controle, seja por sua retirada de circulação - neste caso, a prisão é a solução mais eficaz - ou sendo atendidas por serviços sociais, anunciados como promotores de inclusão.

Essas duas formas de classificação das pessoas menos úteis e potencialmente perigosas, de certa forma, se reproduzem no sistema prisional. A diferença, obviamente, é que não são mais consideradas "potencialmente perigosas", mas simplesmente perigosas. Castel (1997, p. 29) considera haver dois tipos de marginais na sociedade: o primeiro, seria a "marginalidade livre", caracterizada pela distância em relação ao trabalho regular, mas também em relação às formas organizadas da proteção aproximada que se constitui na assistência. A segunda é aquela constituída por pessoas que foram provisória ou definitivamente retiradas da vida social e institucionalizadas em espaços separados, como os usuários de droga, deficientes físicos e mentais, entre outros. A isto, o autor acrescenta a seguinte nota de rodapé:

Poderíamos acrescentar aqui os prisioneiros, provisória ou definitivamente afastados da vida social. A diferença com os marginais se deve ao fato de que a situação deles resulta de uma transgressão das normas sociais, ao passo que os marginais vivem, sobretudo, fora dessas normas. Mas a fronteira é constantemente frágil, como mostra o exemplo dos toxicômanos sempre ameaçados de fazer ressurgir o aparato judiciário. A criminalização da marginalidade é uma forma importante da sua gestão 
social, seja que a precariedade das condições da vida marginal pressiona frequentemente a cometer delitos, seja que certas formas de marginalidade são diretamente qualificadas de delitos como o mostra a criminalização massiva da vagabundagem através de toda a história europeia. (CASTEL, 1997, p. 29).

A consequência dessa distinção é basicamente o tratamento dispensado pelo Estado. Toxicômanos, pessoas com deficiência física ou mental, inválidas, entre outras, são dotadas de um estatuto, baseado nas deficiências, que lhes impõe uma proteção social especializada, ou, pelo menos, esta era a orientação durante o período do Estado do Bem-Estar Social.

Rose (1996) diz que o fim desse período reduziu o papel dos serviços sociais especializados, deslocando a responsabilidade da superação das condições de marginalidade para os próprios indivíduos, e para as comunidades onde vivem.

Disso decorre que as atribuições antes de responsabilidade dos trabalhadores sociais, na atual conjuntura, são assumidas por entidades filantrópicas e grupos de autoajuda, muitas vezes organizados na comunidade, e que terminam também por exercer a função do controle social.

Ao Estado, neste momento, cabe estimular a criação e o funcionamento dessas iniciativas, e acompanhar seu trabalho, sem, contudo, envolver-se diretamente. Vale, nesta conjuntura, a reflexão de Adorno (1990) sobre o papel da filantropia na gestão dos sobrantes no final do século XIX, início do XX, em São Paulo, já citada anteriormente: prestar socorro e assistência sem o reconhecimento de direitos.

A análise de Garland (2008) sobre as mudanças nas orientações do funcionamento do sistema prisional nos Estados Unidos e Inglaterra, entre os períodos denominado Estado de Bem-Estar Social e aquele denominado "neoliberalismo"105, se aproxima das reflexões de Rose (1996) para a sociedade em geral. O advento do Estado do Bem-Estar Social - com sua situação de empregos abundantes, programas de seguridade social, surgimento de setores da classe média constituídos por trabalhadores sociais e técnicos do Estado e a produção de conhecimento técnico - que apontava serem os pobres, incluindo os delinquentes, vítimas da falta de acesso aos direitos -, possibilitou a formatação de um quase consenso social em torno da ideia da reabilitação dos presos com base na atenção social.

Quase consenso, porque Garland (2008) lembra que os setores mais pobres da população não se envolveram no debate que levou à formatação do "previdenciarismo penal", mas também não se opuseram. Havia ambiente social de otimismo e, consequentemente,

\footnotetext{
${ }^{105}$ Sem desconsiderar a complexidade do debate existente em torno do termo "neoliberalismo", neste trabalho, é considerado como o conjunto de ações de governos que levaram à retirada, ou redução, do papel do Estado na garantia de direitos sociais.
} 
solidariedade, estimulada pela crença de que todos poderiam compartilhar do desenvolvimento experimentado por alguns.

As mudanças no contexto econômico, a crise do mercado de trabalho e a quase total retirada do Estado na promoção de políticas sociais teve reflexos no sistema prisional. A solidariedade, antes destinada a todos, sofreu influência do "neoconservadorismo" (GARLAND, 2008, p. 216), que estimulado por governos como o de Margareth Tatcher e Ronald Reagan, em que o "problema do comportamento imoral [passou a ser considerado] como um problema inerente do comportamento das pessoas pobres. [...] Havia alguns comportamentos e pessoas que não deveriam ser tolerados, razão pela qual políticas sociais e criminais novas e mais repressivas foram criadas (2008, p. 219).

O "neoconservadorismo", com sua condenação das imoralidades, trouxe a necessidade da distinção entre os grupos, sobretudo entre os pobres, tendo a delinquência como divisor (FOUCAULT, 1979, p. 133). A solidariedade entre os grupos sociais passou a ser compartilhada apenas entre as pessoas consideradas honestas. Segundo o Foucault, é neste contexto que surge a figura da vítima como uma peça fundamental na gestão dos crimes. Só as vítimas eram merecedoras de solidariedade, pois era com ela que a sociedade se identificava.

Assim como acontecera no princípio da organização da prisão disciplinar, os criminosos foram desumanizados (FOUCAULT, 1979, 1987; GARLAND, 2008; CHRISTIE, 1998). O sistema prisional, sobretudo nos EUA, recebeu críticas de setores progressistas e conservadores. Pelos primeiros, foi acusado de seletivo e destinado somente a pobres e negros, entre outras deficiências. Pelos conservadores, foi criticado por sua ineficiência no combate ao crime.

A plataforma política de reforma do sistema prisional, para torná-lo mais eficiente, foi assumida por partidos de direita e de esquerda, assim como por políticos de oposição e situação.

Garland (2008) afirma não ter existido nenhuma voz a defender o modelo do previdenciarismo penal, que, assim, sucumbiu, levando consigo o ideal da reabilitação. Em seu lugar, fortaleceu-se a ideia de que a função da prisão é conter, segregar, imobilizar os perigosos, apenas isto.

Foucault afirmava que não se devia buscar progressos nas instituições (1979, p. 140), no sentido de uma evolução humanizadora, as quais cumprem papéis historicamente construídos. Da mesma forma, Garland (2008) diz que a história das prisões não é uma 
sucessão linear de períodos caracterizados por determinantes sociais, econômicas e políticas, que, por sua vez, interferem na condução da justiça criminal.

Assim, o previdenciarismo penal conviveu com elementos das prisões disciplinares, e as características desses dois momentos da gestão nas prisões podem ser identificadas na atualidade ou na prisão pós-disciplinar (CHANTRAINE, 2006).

Outra observação fundamental para a compreensão das prisões na atualidade é o fato de que algumas características se disseminam entre diferentes países, mesmo com contextos socioeconômicos e culturais diferentes (GARLAND, 2008; CHANTRAINE, 2006).

É assim que, no Brasil, pode-se encontrar características da prisão disciplinar, embora de fato nunca se tenha estruturado um sistema prisional baseado na organização, classificação e controle, e de as unidades prisionais brasileiras historicamente sempre estarem mais próximas de depósitos de seres humanos do que de espaços disciplinares (ADORNO, 1991; KOERNER, 2006; ADORNO; SALLA, 2007). Também podem ser identificadas características do previdenciarismo penal, ainda que muito pontuais e frágeis (TEIXEIRA, 2006), e, agora, da prisão pós-disciplinar, bem como encarceramento em massa, endurecimento das penas e ampliação do que se compreende por crime, todas estas medidas iniciadas nos EUA, que chegaram por aqui, umas com maior intensidade, outras com menor.

É dessa forma que se percebe, com base na pesquisa realizada, a duplicidade que marca as formas de consideração da população carcerária: como pobres, que devem ter acesso a direitos por meio de programas sociais, ou como pessoas perigosas que merecem ser contidas.

E os programas de educação ilustram essa situação. Se for apenas para conter, neutralizar qualquer ação, concretizada de qualquer forma, basta, porque o sentido é apenas ocupar o tempo para minimizar as possibilidades de problemas disciplinares ou reduzir os riscos (CHANTRAINE, 2006).

No entanto, se a proposição de Paulo Freire (1996) é aceita, e considera-se a população carcerária como formada por pessoas que foram traídas no seu direito de ser, então as atividades educativas deveriam assumir a condição de "antidestino" (NÚÑEZ, 2009, p. 250), por fornecer elementos para a construção do futuro, mesmo considerando que, no ambiente prisional, está inserida entre as ações de controle.

Sobre a educação nas prisões como forma de controle, as observações de Nuñez (2009) e Freire (1996) propõem que educadores, atuando com populações marginalizadas, assumam a posição política de fazer da sua ação pedagógica meio e fim de sua ação política. Nesse sentido, é exemplar a atuação do ITTC. As educadoras disseram: não se trata de "passar 
a mão na cabeça das presas", como temiam os agentes de segurança, mas de não se calar diante das violações testemunhadas. Obviamente, estratégias são armadas, o encaminhamento de cada situação é discutido com as educandas. E daí decorre a primeira e a segunda distinção entre as ações educativas e as demais atividades que compõem o aparato de controle - a primeira distinção diz respeito à sua orientação: se destinada a ocupar o tempo ou a cumprir a função de antidestino. A segunda é oferecer a possibilidade da fala, da palavra, do desabafo. A dimensão da expressão oral é um tema recorrente nas atividades educativas na prisão. Internas afirmavam frequentar o curso de alfabetização para aprender a falar (GRACIANO, 2005); os cursos de música e de injeção eletrônica são espaços para conversas, conselhos; "Leitura Ativa", "Quem Somos Nós" e "Promotoras Legais Populares" propiciam espaços de "desabafos", quando se pode confiar na escuta alheia tanto em relação a questões familiares e da vida amorosa quanto das dificuldades enfrentadas na instituição. G., F. e P., educador e educadoras, relacionam, entre as principais conquistas dos projetos, a possibilidade de estimular o estabelecimento de vínculo de amizade e confiança entre as internas.

Essa é uma dimensão bastante significativa, principalmente se considerada a observação de Chantraine (2006, p. 100) sobre o fato de um dos resultados mais perversos do sistema de privilégios ser exatamente o estabelecimento de um incrível individualismo, em que todos desconfiam de todos "[...] seu funcionamento leva-os [os presos] a dizer, não sem amargura, que o sistema bombom apodreceu o ambiente e que agora, com o sistema bombom, é cada um por si”.

Preocupa, então, outra dimensão do controle que opera nas prisões, percebida por $M$., integrante do GDUCC: a inibição da fala em razão da presença de lideranças de uma facção criminosa no grupo. $M$. conta que, em uma determinada dinâmica, houve um problema de relacionamento entre um interno e uma universitária. A tensão foi discutida no grupo, e um dos integrantes afirmou que o grupo não precisava se preocupar, pois a situação seria resolvida. E foi: o rapaz não voltou mais ao grupo e os universitários do GDUCC ficaram sabendo que ele desrespeitara uma regra cara à facção - o respeito incondicional aos visitantes. Ficou, para os integrantes do GDUCC, a suspeita de que a sanção não tinha sido apenas a exclusão das atividades, mas também, violência física.

A terceira distinção entre a educação a as demais ações de controle também está relacionada à ação política dos educadores - é a sua possibilidade de se converter em agente de controle da instituição.

Garland (2008), ao descrever o previdenciarismo penal, relaciona entre suas características a ampliação do controle sobre os funcionários do sistema penal e carcerário, 
ação que envolveu o estabelecimento e monitoramento de metas, apresentação periódica de relatórios, entre outros mecanismos. Esta, certamente, foi uma característica que não se difundiu no sistema brasileiro. Por aqui, em que pesem os esforços de alguns governos em sistematizar informações do sistema penitenciário e organizar sua estrutura de forma a transformá-lo em sistema de fato, com alguma organicidade (TEIXEIRA, 2006; SOARES, 2007), permanece a histórica autonomia dos dirigentes de unidades, apontada por diversas pesquisas no campo (SALLA, 1997; KOERNER, 2006; ADORNO, 1991; SOARES e ILGENFRITZ, 2002). Não há controle nenhum sobre as unidades prisionais, e seu interior permanece em segredo (FOUCAULT, 2006), como já apontado neste e em outros trabalhos.

Então, como governos não conseguem adentrar a prisão - como demonstrado no Capítulo 2 -, a única maneira de a realidade do cárcere transpor seus muros é por meio das "pessoas de fora" que por lá circulam.

Analisando o papel dos trabalhadores sociais no ambiente prisional, Foucault (2006, p. 79-80) salienta sua contribuição para a manutenção da ordem institucional, mas admite seu papel político na divulgação de seu cotidiano:

\footnotetext{
Não se pode encostá-los (trabalhadores sociais) na parede dizendo-lhes simplesmente: vocês consolidam o sistema exatamente na medida em que nele permanecem. Encontramos sem cessar pessoas que são educadores de prisão, psicólogos em instituições vigiadas, assistentes sociais etc., que fazem um bom trabalho político e que, ao mesmo tempo, de fato, sabem muito bem que, a cada vez que fazem alguma coisa, reconduzem todo esse setor do trabalho social, mas não é tão simples assim. Uma vez que o segredo é uma das formas importantes do poder político, a revelação do que se passa, a "denúncia" vinda do interior é uma coisa politicamente importante.
}

Lembra que a participação dos trabalhadores sociais na mobilização feita pelo Grupo de Informação sobre as Prisões (GIP) foi fundamental para informar a sociedade sobre o cotidiano prisional. "A inquietação da administração penitenciária, em boa medida, veio daí. Se os estalidos vinham não somente dos "vigiados", mas também dos "vigilantes", como vigiar os vigilantes? Bentham dizia que era um problema político capital” (2006, p. 80).

E Foucault (2006) estava referindo-se aos trabalhadores sociais, ou seja, pessoas vinculadas profissionalmente ao sistema. No caso de educadores e educadoras, a situação é ainda mais peculiar. Este trabalho trouxe experiências de pessoas que atuam no sistema prisional, representando instituições - igrejas, ONGs e universidades. São educadores/as, mas não são funcionários de sistemas públicos de ensino, configurando então uma relação entre sociedade civil e Estado, tema que será tratado no próximo capítulo. No entanto, há situações, 
em Estados onde existe educação formal no sistema prisional, em que os educadores/as pertencem ao quadro funcional dos órgãos de gestão da educação.

Nas duas situações, há tensões entre as lógicas da educação e da repressão. Professoras são perseguidas, sua competência técnica desqualificada, seu comportamento repreendido ${ }^{106}$.

Para além do risco de produzirem conhecimento com sentido, numa instituição formatada para que as atividades não tenham sentido - como já apontado anteriormente -, a presença de educadores/as nas prisões pode ser mais incômoda ao sistema justamente pelo potencial de controle inerente às práticas educativas.

Diferentemente de outros profissionais que atuam no sistema, que se relacionam com os presos de forma fragmentada e esporádica -, as práticas educativas pressupõem regularidade no contato com o grupo e vários tipos de registro: da presença dos educandos; datas dos encontros ou aulas; atividades realizadas em cada uma delas, entre outros. Para os educandos, estes mecanismos não representam qualquer controle, uma vez que só podem participar quando autorizados e guiados pelos profissionais da segurança.

Já para a administração da prisão, a produção desses documentos causaria “inquietação" (FOUCAULT, 2006). Finalmente, a quantidade de revistas inúteis ${ }^{107}$ às celas seriam registradas com base na suspensão das atividades, o baixíssimo número de dias úteis seria denunciado e talvez se pudesse discutir socialmente se as atividades realizadas são “aceitáveis" (TOMASEVSKI, 2001) do ponto de vista da qualidade. E as faltas de estudantes poderiam ser questionadas, como fez o ITTC, e talvez contassem histórias de pessoas doentes nas celas ou cumprindo castigos arbitrários. Finalmente, a repetição do mesmo nome em diferentes atividades poderia, ainda que de uma forma bastante sutil, revelar o sistema de privilégios que faz com que a maioria da população carcerária permaneça excluída de qualquer possibilidade de voltar ao convívio social em melhores condições do que entrou.

Obviamente, para que tudo isso aconteça, é preciso, de um lado, a disposição política de educadores em registrar; de outro, que as informações fossem consideradas pela sociedade. Por ora, constata-se apenas o potencial da educação em levar inquietação ao sistema.

\footnotetext{
${ }^{106}$ Durante o seminário “A educação como direito humano: a escola na prisão", realizado em 27 e 28 de janeiro de 2009, em Belém (PA), durante o Fórum Social Mundial, professoras que atuavam no sistema prisional de diferentes Estados narraram suas dificuldades de atuação expondo, a um só tempo, a fragilidade de sua condição perante o aparato de segurança e a importância de sua presença justamente para questionar esta ordem.

${ }^{107}$ Inúteis porque, a julgar pelas notícias dos jornais, não servem para inibir o uso de celulares ou drogas.
} 


\subsubsection{O ciúme}

Foi recorrente em todas as entrevistas - exceto naquela realizada com a professora de música - explicar entraves às práticas educativas impostos por funcionários da prisão em virtude de “ciúmes" da atenção, que as atividades representam, dispensada à população carcerária.

Essa impressão é compartilhada por pessoas que fazem pesquisa no sistema prisional muitas foram as vezes que, ao justificar a ida à penitenciária para entrevistar internos/as, funcionários perguntaram se também não haveria interesse em ouvir o que eles teriam a dizer sobre educação.

Um dos significados possíveis para o termo ciúme é “emulação, competição, rivalidade" 108 , e a investigação sobre as razões e consequências desse sentimento em relação aos internos constitui-se em interessante objeto de pesquisa.

Neste trabalho, apenas para efeito de registro, e tentando elucidar as reflexões das educadoras $F$. e $P$., do ITTC, sobre as condições de trabalho experimentadas pelos funcionários das prisões, alguns dados são apresentados a seguir.

Conforme alertou Roberto da Silva durante o seminário sobre educação em prisões ${ }^{109}$, é preciso considerar que os agentes penitenciários cumprem grande parte da pena com os internos. Ou seja, também são privados de liberdade durante os turnos de trabalho.

Isto significa que partilham com os internos a tensão imposta por unidades superlotadas, sem condições dignas de permanência. A esta situação, soma-se o assustador aumento da população carcerária sem a correspondente contratação de funcionários. A situação de São Paulo não é diferente daquela existente em outros estados, conforme indicam Adorno e Salla (2007, p. 22):

Em São Paulo, no sistema penitenciário, em 1994, a proporção era de um funcionário para 2,17 presos [...]. Em 2006, a proporção conheceu queda: um funcionário para 4,99 presos (25.172 funcionários para 125.523 presos). Ou seja, a população presa quase que havia quadruplicado, enquanto a de funcionários (cerca de $80 \%$ deles são agentes de segurança) nem mesmo havia duplicado. Pelo Brasil, a situação não é diferente, e por vezes ainda mais grave em alguns Estados.

Teixeira (2006, p. 153) explica a redução de 18 mil funcionários da Secretaria de Administração Penitenciária de São Paulo entre 1999 e 2006, durante a gestão de Nagashi Furukawa, pela busca da redução de gastos. Descreve que o aumento da proporção entre o

\footnotetext{
108 Novo Dicionário da Língua Portuguesa. Editora Nova Fronteira, p. 333.

${ }^{109}$ I Seminário de Educação em Prisões no Estado de Rondônia, promovido pela Unesco e o governo do Estado de Rondônia no período de 5 a 7 de agosto de 2009.
} 
número de presos e o número de funcionários foi louvada pela SAP por ter significado, entre 1999 e 2002, redução de 23\% no custo mensal de manutenção dos internos, passando de $\mathrm{R} \$ 1.000,00$ em 1999 para R\$767,00 em 2003.

Christie (1998, p. 29), ao explicar as razões do reduzido número de pessoas presas na Noruega, conta que os funcionários do sistema penitenciário não permitem a superlotação. Fazem mobilizações, pressionam políticos, acionam organizações de direitos humanos, e vinham conseguindo manter a manutenção de um preso por cela. No processo de mobilização, o órgão de representação da categoria emitiu a seguinte nota:

Nós nos opomos frontalmente à decisão de se colocar dois presos em celas construídas para abrigar uma pessoa e apontamos as seguintes consequências:

- Não é aceitável do ponto de vista da segurança.

- As condições de trabalho dos guardas vão se deteriorar.

- Não é aceitável deixar os presos viverem abaixo de padrões sociais e de saúde decentes.

A impossibilidade de o Estado aumentar o número de vagas em prisões provoca uma situação bastante peculiar, que é a constituição de filas de espera para as prisões. Dessa forma, as pessoas sentenciadas ficam aguardando em suas casas até que surjam vagas no sistema.

Realidade muitíssimo diferente da verificada no Brasil, em geral, e em São Paulo, em particular, onde estudo ${ }^{110}$ elaborado pela Secretaria de Gestão Pública do Governo do Estado de São Paulo, com o objetivo de avaliar o impacto do absenteísmo comprovado na folha de pagamento da administração direta paulista, demonstra que a Secretaria de Administração Penitenciária é o segundo órgão do governo do Estado em frequência ${ }^{111}$ do número de licenças médicas, registrando índice de 43,43\%. O primeiro é a Secretaria Estadual de Educação, com frequência de 49,5\%.

O índice de frequência da SAP vem aumentando anualmente, passando de 22,32\%, em 2003, para 31,82\%, em 2004; de 35,81\% em 2005, até chegar a 43,43\% em 2006, último ano da pesquisa, de acordo com as informações contidas na página eletrônica do governo do Estado.

Consequentemente, os custos do absenteísmo na SAP também se ampliaram, sendo de $\mathrm{R}$ \$ 9.317.471,95 em 2003; R\$ 13.127.517,23 em 2004; R\$ 17.390.186,03 em 2005 e R\$ R\$ 31.824.133,77 em 2006.

\footnotetext{
${ }^{110}$ Disponível em: <http://www.recursoshumanos.sp.gov.br/qualidadedevida/ absenteísmo/ absenteismo.htm>. Acesso em: 20 out. 2009.

${ }^{111}$ A Frequência é estabelecida pela razão entre o número de licenças e o número de funcionários de cada órgão da administração direta.
} 
O estudo mostra que o absenteísmo está relacionado às licenças médicas, sendo que na SAP a principal causa, com 37,9\% dos casos, são os transtornos mentais, comportamentais e depressivos, e o segundo grupo mais frequente são as doenças osteomusculares, com 15,98\% das ocorrências.

Os resultados demonstram uma situação bastante coerente com o tipo de trabalho: falta equilíbrio emocional para o exercício da função e isto custa muito - recursos públicos, mas também a intensificação do sofrimento de seres humanos, levados a conviver no ambiente prisional, em condições desumanas. Como define Miltford ${ }^{12}$ (1974, p. 297 apud CHRISTIE, 1998, p. 106) :

Nós que estamos do lado de fora não gostamos de pensar em diretores e guardas de penitenciárias como nossos representantes. Mas eles são, e estão intimamente unidos, num abraço mortal, com seus cativos humanos atrás dos muros das prisões. Nós também, por extensão. Um significado duplo terrível é assim conferido à questão original da ética humana: sou eu o carcereiro do meu irmão?

\subsection{Algumas conclusões}

\subsubsection{Fragilidade e precariedade das ações}

O campo pesquisado contribui para ampliação do quadro construído com base na análise de mídia. A primeira delas é a presença da Igreja Católica na atividade de alfabetização em diferentes estados do País, incluindo São Paulo. Com base nas reportagens, entrevistas e informações obtidas nas páginas eletrônicas das agências estatais responsáveis pela oferta da educação no ambiente prisional, não há convênios estabelecidos com igrejas para a alfabetização, e a outra possibilidade apontada era por meio da atuação de monitores sentenciados, remunerados pela Funap.

A alfabetização integra a modalidade Educação de Jovens e Adultos, estabelecida em normas, portanto, deveria ser garantida pelo Estado, ainda que por meio de parcerias com a sociedade civil, no campo da educação não formal.

112 MITFORD, Jessica. The american prison business. Grã-Bretanha, 1974 (publicado nos EUA, em 1971, como Kind and usual punishment). 
No caso da Pastoral Carcerária, é a instituição que se encarrega de todos os detalhes: busca doações de lousa, giz, material didático, caderno e lápis para os educandos. Busca, de forma autônoma, sem qualquer apoio do Estado, formar os educadores, agentes da pastoral.

Também as igrejas, ou religiões, estão presentes na educação por meio de cursos profissionalizantes e de arte-educação, como demonstrado neste capítulo. Da mesma forma, não há qualquer aproximação com o Estado, que não oferece nenhum apoio.

A presença da universidade não é institucional, mas, sim, movida pelo interesse pessoal de estudantes e professores. Havia a exceção do "Leitura Ativa", que contava com o apoio da Fesp, mas o projeto foi extinto, e o educador busca agora dar continuidade como voluntário da igreja católica. No caso do GDUCC, há uma tentativa de buscar institucionalidade por meio da sua inclusão nas atividades de extensão, mas até o encerramento deste trabalho, os estudantes se organizavam para manter o grupo.

A experiência das ONGs revela intensa fragilidade do ponto de vista da sustentabilidade. Colibri fechou quando terminou o convênio com o Ministério da Saúde; Diet deixou de realizar o trabalho nas prisões quando o educador responsável deixou a instituição, para trabalhar como vendedor de uma loja de departamentos; e ITTC, ao longo de sua história, vem reduzindo seu campo de atuação, e o "Quem Somos Nós" depende do financiamento da Petrobrás, sem qualquer segurança de continuidade.

A compreensão deste cenário será tema do capítulo 4, à luz das reflexões sobre a relação entre sociedade civil e Estado desde a década de 1970, no Brasil. Por ora registra-se apenas a precariedade das condições de realização das atividades, que dão sentido ao alerta de Trilla (2009) sobre o risco de o Estado, em busca de economia, substituir a educação formal pela não formal, obviamente muito mais barata e, na grande maioria dos casos, totalmente grátis para o Estado.

\subsubsection{Limites e possibilidades}

A análise das atividades demonstrou que as dificuldades encontradas para a realização do trabalho não são acasos, ou resultados de comportamentos individuais de funcionários descomprometidos com a reabilitação dos presos. Ao contrário, os entraves cumprem o papel de garantir que a prisão sirva àquele que é seu único objetivo: conter os grupos sobrantes. 
Para tanto, devem funcionar alguns dispositivos que, agindo em conjunto, levam os presos ao total imobilismo - os habitantes dos pavilhões "do fundo" sobre quem $M$. falou - ou à participação contida, controlada, em todas as atividades.

A análise das atividades permite observar características que teóricos identificam na instituição prisional em geral: o sistema de privilégio; a fluidez das regras cotidianas, que gera a rigidez da possibilidade do controle; a utilização das lideranças como canal de comunicação e representação entre população carcerária e a administração da prisão, entre outros; a garantia das atividades sem sentido, destinadas apenas a ocupar o tempo.

Apesar desse quadro, educadores/as insistem e, de maneiras diferentes, buscam concretizar experiências educativas que possam contribuir com a "problematização do futuro" por meio de ações no presente.

Regras são constantemente questionadas, senão diretamente "não dá para bater de frente", disseram educadores/as nas entrevistas, mas na insistência e na busca de alternativas. Foi assim que entrou a ambulância no curso de injeção ou o atendimento médico para a moça que sofreu aborto foi garantido.

Pequenas conquistas? Sim, se o critério for a estatística - nenhuma das iniciativas aqui narradas atende $10 \%$ da população das unidades, e não há perspectiva de continuidade. Não se for considerado que os processos educativos geram consequências imensuráveis e muitas vezes impossíveis de captar no curto prazo.

A. é bastante contida ao comentar possíveis resultados do PLP, no entanto, esta pesquisa foi motivada pela forte referência do curso para algumas mulheres, tanto na organização da sua vida pessoal como na atuação coletiva, ainda no cárcere - como já exposto, a monitora sentenciada do curso de alfabetização tornou-se multiplicadora do conteúdo. Ainda que informal, descontínua e desorganizadamente, suas aulas eram repletas de discussões sobre direitos e deveres.

Há ainda a dimensão da autoestima, da consciência da sua humanidade, pelo exercício da busca do conhecimento. A cobertura de garrafa "pet" não foi concretizada, mas o processo de pesquisa certamente contribuiu para que as alunas pudessem "ser mais", como aponta Paulo Freire. 


\subsubsection{Quem controla quem}

É inegável que a presença de "pessoas de fora" ou, como chamava Foucault, de "trabalhadores sociais" na prisão contribui para a manutenção do sistema. E isto ocorre menos por seu potencial de controle sobre os presos, do que pela legitimidade que conferem ao seu funcionamento e a seus organizadores.

Sua presença induz à avaliação de que há preocupação do Estado com a reabilitação dos presos e de que ações estão sendo empreendidas para atingir este objetivo; também faz com que se acredite que não há nada a esconder, afinal, a sociedade está presente.

Obviamente, a observação mais cuidadosa sobre as condições de realização das atividades traz a impressão de tratar-se de "ilusão de ótica", as coisas parecem estar lá, mas não estão exatamente.

No entanto, é justamente o potencial de controle das atividades educativas que pode trazer inquietude ao sistema, caso educadores/as aceitem agir politicamente, a exemplo do que faz o ITTC.

Há muito a ser visto, perguntado e contado sobre e na prisão. É impossível às pessoas de fora circularem livremente, conversarem livremente com funcionários e educandos. No entanto, os pressupostos contidos no ato de educar - garantia das condições necessárias ao processo de construção de conhecimentos e toda a dinâmica dos registros - podem transformar-se em eficientes mecanismos de controle: sobre a própria instituição prisional.

Esta característica torna a educação - formal ou não formal - compreendida como direito humano ou parte do aparato necessário ao desenvolvimento humano, duplamente essencial: por seu potencial de desenvolvimento pessoal, mas também por sua vocação para a transformação coletiva (SEN, 2000). 


\title{
CAPÍTULO 4 - AS FORMAS DE PARTICIPAÇÃO NUM SISTEMA QUE SE FECHA
}

\begin{abstract}
Sempre me davam muita autonomia, tanto a diretora geral, como a diretora de educação. Muita, muita autonomia: vai em busca, quer trazer? Traz... vamos conversar, vamos participar. [...] A gente teve um curso de gestor que o governo abriu a possibilidade de a gente fazer; então, focava muito nas parcerias, como fazer as parcerias, ir em busca - o governo sozinho também não tem verba pra tudo isso. ( $S$. funcionária de uma penitenciária paulista)
\end{abstract}

O trabalho de campo desenvolvido ao longo desta pesquisa identificou a diversidade do perfil das organizações que realizam atividades educativas na prisão. Este capítulo busca contextualizar a atuação de organizações da sociedade civil em dois campos distintos: aquele vinculado à defesa dos direitos da pessoa humana, notadamente em situação de privação de liberdade, e na educação.

Utilizamos reflexões de autores como Dagnino (2002), Costa (2002) e Gohn (2008), para traçar o histórico da participação de organizações da sociedade civil na esfera pública do período da ditadura militar até a década de 1990, demonstrando as transformações ocorridas em suas demandas e formas de incidência, conforme Benevides (2004, 1996), Comparato (2003), Dallari (2004) e Haddad (2002).

Tendo como elemento condutor a Lei de Execução Penal e os programas de direitos humanos - as três versões do nacional e a versão estadual de São Paulo -, apresentamos reflexões sobre os limites e as possibilidades da participação da sociedade civil no ambiente prisional, adotando as análises de Garland (2008), Christie (1998), Wacquant (2002) e Salla $(1997,2007)$ sobre a atual forma de organização das instituições penais.

Por fim, identificamos sinais de mobilização, por parte de organizações e espaços de articulação da sociedade civil, em favor dos direitos educativos das pessoas encarceradas. $\mathrm{Na}$ impossibilidade de analisar os resultados ou consequências dessa atuação, este capítulo registra aquilo que se anuncia como uma ação inédita no campo das políticas prisionais: o tensionamento da relação sociedade civil e Estado em torno da garantia da educação nas prisões. 


\subsection{Sociedade civil e esfera pública}

\subsubsection{Diferentes perfis}

O conjunto das informações, constituído por meio das diferentes fontes e descrito anteriormente, permite identificar diferentes atores não vinculados ao Estado, que desenvolvem atividades de educação não formal no ambiente prisional.

Um primeiro grupo é formado por instituições ligadas ao setor empresarial. De âmbito privado, foram identificadas as entidades do sistema "S" - Senai, Sesc, Sesi e Sebrae -, o CIEE, a Fundação Roberto Marinho e a Fundação Bradesco. Há também a presença de instituições vinculadas a empresas estatais, como a Fundação Banco do Brasil e a Petrobras; esta última não atua diretamente nas prisões, mas financia a projeto "Quem Somos Nós", como informado anteriormente.

No segundo grupo, estão as instituições de ensino de ensino superior e nível médio. Nota-se que a presença de instituições de ensino superior é mais frequente, sendo que apenas os gestores de São Paulo citaram a atuação do Centro Paula Souza, por meio de uma parceria com a Funap. Já entre as instituições de ensino superior, foram identificadas faculdades públicas e privadas, bem como universidades públicas e privadas. A forma de atuação também pode variar entre o estabelecimento de relações institucionais com agências estatais ou iniciativas pessoais de estudantes, para o desenvolvimento de estudos ou trabalhos acadêmicos ou ação voluntária.

O terceiro grupo é formado por pessoas voluntárias, vinculadas a diferentes igrejas. Nesta pesquisa, foram identificadas iniciativas evangélica, católica e espírita.

Um quarto grupo, não identificado no trabalho de campo, mas apontado na bibliografia pesquisada e citado em entrevistas, é constituído por iniciativas voluntárias pessoais, quando os responsáveis por atividades de formação não estão vinculados a nenhuma organização. Neste grupo, há registro de ações nas áreas da Saúde, Comunicação e ArteEducação ${ }^{113}$.

Foi identificada ainda a presença da Central Única do Trabalhadores (CUT) na realização de atividades de alfabetização em prisões, o que configura um tipo diferenciado de instituição.

\footnotetext{
${ }^{113}$ VARELLA, 1999; PRADO, 2003; MENDES 2001, 2005; JOCENIR, 2001; entrevista com C., diretora de escola na prisão.
} 
Por fim, o último grupo é formado por instituições que se autodenominam, ou são denominadas pela imprensa ou agentes estatais, "ONGs" - organizações não governamentais.

\subsubsection{Diversidade entre as ONGs}

O termo ONG não tem significado jurídico e, historicamente, assumiu diferentes significados. De acordo com Gohn (2008, p. 75), após a Segunda Guerra Mundial, a nomenclatura foi cunhada pela ONU para designar entidades que não representavam governos, mas tinham "presença significativa" em diferentes países, como a Organização Internacional do Trabalho (OIT), Cruz Vermelha e outras, que posteriormente passaram a fazer parte da estrutura da própria ONU, como a Unesco e a FAO.

No Brasil, o termo foi socialmente difundido pelos meios de comunicação durante a Conferência Mundial sobre Meio Ambiente, realizada no Rio de Janeiro, em 1992, embora existam instituições denominadas ONGs que atuam desde a década de 1960 (HADDAD, 2002).

O termo, porém, não permite a caracterização da atuação ou missão dessas organizações, sendo utilizado para designar "uma infinidade de entidades com histórias, tamanhos, missões, modelos organizacionais e mecanismos de sustentabilidade completamente diferentes umas das outras. Por se definir como não Estado, e por suas características de ser sem fins de lucro, portanto como não mercado, cabe aí uma diversidade enorme de instituições" (2002, p. 15).

O autor chama a atenção para o fato de não existir marco legal que regule o trabalho das "ONGs" e que, de maneira geral, elas se constituem juridicamente como Associação Civil de Direito Privado Sem Fins de Lucro ou Fundação, figuras jurídicas que também ajudam muito pouco na caracterização dessas organizações, uma vez que são usadas por instituições muito diversas, como escolas católicas, hospitais, organizações filantrópicas, times de futebol, associações de moradores, entidades beneficentes, grupos políticos e tantas outras entidades, todas privadas sem fins de lucro.

Sem desconsiderar a complexidade das relações e reflexões contidas no debate sobre a caracterização e o papel das ONGs no Brasil, neste trabalho, o conjunto das instituições e pessoas identificadas, e assinaladas acima, será denominado sociedade civil, tal qual propõe 
Costa (2002) ao afirmar que, no Brasil, a noção de sociedade civil ${ }^{114}$ nasce nos anos de 1980 , juntamente com a noção de espaço público, locus de sua atuação.

No debate contemporâneo sobre o conceito de sociedade civil, Costa identifica duas vertentes interpretativas. Na primeira, a denominada "enfática", a sociedade civil é vislumbrada como um conjunto de associações autônomas e independentes que força permanentemente a democratização das instituições estatais, exercendo controle e pressão sobre ações do Estado, por meio da participação nas arenas institucionais (parlamento, esferas estatais, etc.) e não convencionais (movimentos sociais, protestos coletivos).

Na segunda vertente, a "moderada", sociedade civil é apenas a

apresentação descritiva das conformações político-sociais previamente existentes no contexto liberal-democrático [...] e abrange a teia de instituições e atividades que conferem forma e expressão ao espírito cívico, este entendido como a 'consciência coletiva da participação conjunta na sociedade. (COSTA, 2002, p.49).

Como toda construção teórica, as vertentes propostas por Costa contribuem para a compreensão da realidade, mas esta é sempre mais complexa, não sendo possível representála esquematicamente. Assim, é possível associar algumas das iniciativas descritas neste trabalho à vertente "enfática", no que se refere ao exercício do controle e pressão sobre o Estado, ou seus representantes, no sentido de melhorar as condições de existência no cárcere ou questionar suas regras.

Outras iniciativas podem ser interpretadas como "moderadas", buscando a atuação no contexto prisional sem, contudo, tentar transformá-lo. A transformação pretendida é a dos indivíduos, e a instituição prisão não é objeto de crítica. Tais iniciativas aproximam-se da noção de filantropia apresentada por Adorno (1990), pela qual entidades assumem tarefas de atendimento às populações marginalizadas, com o consentimento do Estado, atuando no vácuo deixado por este, sem criticá-lo por isso.

\footnotetext{
${ }^{114}$ Sobre a noção de sociedade civil, Costa (2002) apresenta definições clássicas do termo, chamando a atenção para o fato de as diferenças entre elas residir na relação estabelecida com o Estado. Assim, sociedade civil é vista como extensão do Estado para Aristóteles; como possibilidade de defesa contra o Estado, por meio de organizações para A. Fergusson; reconhecida como sociedade regulada por autoridade capaz de assegurar liberdade e segurança pelos jusnaturalistas; tida como espaço onde coexistem a defesa dos interesses individuais (economia) e a defesa dos interesses coletivos (aparato jurídico, administração pública e corporações) em Hegel; sinônimo de sociedade burguesa, portanto, fonte e expressão do domínio da classe dominante para Marx (2002, p. 38-40).

Para Gramsci, é definida como espaço de disputa entre as classes pela hegemonia, completando-se no plano da sociedade política (Estado). "Depreende-se daí o modelo tripartite gramsciano de sociedade: a infra-estrutura econômica do modelo marxiano permanece inalterada; a superestrutura de Marx desdobra-se, entretanto, em duas esferas, a sociedade civil e a sociedade política" (COSTA, 2002, p.40).
} 
No entanto, como demonstrado no capitulo anterior, a dinâmica da prisão exige que as pessoas de fora, para permanecerem atuando, adotem estratégias que tornam impossível classificar sua ação como "enfática" ou "moderada", o que significa que sua relação com o Estado se transforma continuamente - ora embate, ora parceria; algumas vezes denúncias, outras partilha de responsabilidades.

De qualquer maneira, as duas formas de atuação, quando pensadas na perspectiva das prisões, supõem que grupos ou pessoas de fora interfiram em favor da melhoria das condições de vida dos presos. Foucault, ao atuar na criação do Grupo de Informação sobre as Prisões (GIP), em 1971, não atribuía a este o objetivo de melhorar a prisão, mas de propiciar que a opinião pública, os de fora, soubesse da realidade interna por meio dos próprios presos:

Não cabe a nós sugerir uma reforma. Queremos apenas fazer conhecer a realidade. E fazer conhecê-la a cada dia, pois o tempo urge. Trata-se de alertar a opinião e mantêla em alerta. Buscaremos todos os meios de informação [...] Apelamos, portanto, a todas as tribunas possíveis. (FOUCAULT, 2006, p. 2).

E o acesso à informação tinha um objetivo:

\footnotetext{
Nossa inquirição não foi feita para acumular conhecimentos, mas para aumentar nossa intolerância e fazer dela uma intolerância ativa. Tornemo-nos intolerantes a propósito das prisões, da justiça, do sistema hospitalar, da prática psiquiátrica, do serviço militar. (2006, p. 4).
}

Conforme explica Foucault em entrevista a B. Morawe, em 1973 (2006, p. 65), o objetivo do GIP não era reformar a prisão porque esta é apenas parte de "de um sistema mais vasto e mais complexo que é o sistema punitivo: as crianças são punidas, os alunos são punidos, os operários são punidos, os soldados são punidos”. E, para o autor, as formas do sistema penal e da legislação penal são coerentes com a verdade aceita de que "a estabilidade da sociedade capitalista repousa sobre toda essa rede de pressão punitiva que se exerce sobre os indivíduos" (2006, p. 66).

O GIP foi constituído por intelectuais, profissionais liberais, jornalistas e, a eles, juntaram-se familiares de presos, todos comprometidos com a missão de dar voz à população carcerária, tarefa executada pela distribuição, ilegal, de questionários que induziam ao fornecimento de informações sobre o cotidiano na prisão. Alvarez (2006, p. 53) avalia que o GIP obteve "considerável sucesso", mas "grupos de presos não tardaram a reivindicar independência com relação a seus padrinhos intelectuais, e Foucault experimento um sentimento de fracasso após sua autodissolução (em 1972)”. 
Entre os resultados da mobilização empreendida pelo GIP, estão: a disseminação de informações por meio da imprensa, despertando o interesse da opinião pública sobre o tema; a permissão de acesso a jornais pelos presos, proibição existente desde a formação das prisões francesas, e uma onda de manifestações e revoltas da população carcerária de várias unidades, contra suas condições de vida.

Sobre o último aspecto, Foucault (2006, p. 62) considerou as revoltas uma forma política de ação, por terem se desenvolvido coletivamente, envolvendo todos os internos e não grupos específicos, com reivindicações precisas a respeito de suas condições de vida na prisão, apoiada na opinião pública e dirigida "não aos seus superiores, aos diretores de prisão, mas ao próprio poder, ao governo, ao partido no poder."

A experiência do GIP constitui-se, portanto, numa outra possibilidade de atuação de pessoas ou grupos organizados que não tinha uma finalidade específica, além de estimular a comunicação direta entre presos e opinião pública.

\subsubsection{A construção da esfera pública}

Por considerar que a noção de sociedade civil é indissociável da noção de esfera pública sociedade civil só se realiza na esfera pública, Costa (2002) aponta a dificuldade em caracterizar a sociedade civil brasileira anteriormente à década de 1980.

No contexto nacional, o termo "civil" expressa o "não militar" - função políticoestratégica de resistência à ditadura militar. Até meados dos anos 1980, a categoria sociedade civil tinha traços conceituais difusos: incorporava organizações de base, igreja progressista, "novo sindicalismo", empresariado progressista, etc.

No mesmo sentido, Dagnino (2002, p. 9) também reafirma uma das características marcantes das organizações da sociedade civil no seu surgimento: a oposição ao Estado.

\footnotetext{
Considerada o único núcleo possível de resistência a um Estado autoritário, a sociedade civil se organizou de maneira substancialmente unificada no combate a esse Estado, desempenhando papel fundamental no longo processo de transição democrática.
}

E sua atuação foi tão significativa que pode ser tomada como "fundação efetiva da sociedade civil no Brasil, já que sua existência anterior estaria fortemente caracterizada pela falta de autonomia em relação ao Estado" (2002, p. 9). 
Com o fim da ditadura militar, o processo de redemocratização tornou claras as divergências entre os múltiplos grupos que compunham "sociedade civil", explicitando a heterogeneidade do bloco que até então se apresentava coeso em torno de um mesmo objetivo.

Comentando a heterogeneidade expressa no interior da sociedade civil e a redefinição de sua missão a partir do final da década de 1980, Dagnino (2002, p. 10) também afirma o controle sobre as ações do Estado como uma das características da atuação dessas instituições:

[...] na medida em que o retorno às instituições formais básicas da democracia não produziu o encaminhamento adequado por parte do Estado dos problemas de exclusão e desigualdade social nas suas várias expressões, mas antes coincidiu com o seu agravamento.

Essa nova forma de atuação tem como consequência a ênfase na construção de uma nova cidadania. "A redefinição da noção de cidadania, empreendida pelos movimentos sociais e por outros setores sociais na década de 1980, aponta na direção de uma sociedade mais igualitária em todos os níveis, baseada no reconhecimento dos seus membros como sujeitos portadores de direitos [...]" (DAGNINO, 2002, p. 10).

Nos anos de 1990, no contexto da reforma do Estado (HADDAD, 2003a, p.77; COSTA, 2002, p. 58-59), a fim de reduzir a sua presença na garantia de direitos sociais e econômicos, houve o estímulo à participação da sociedade civil para a execução de ações em parceria com o Estado, muitas vezes em substituição ao próprio.

Nesse contexto, Gohn (2008, p. 18)) destaca a convivência de dois grupos distintos de organizações. Um, denominado "antigo" associativismo, "advindo dos movimentos sociais populares (na maioria urbanos) dos anos 70 e 80", e o "novo associativismo" ou "associativismo do terceiro setor", "que é pouco ou nada politizado, na maioria das vezes avesso às ideologias e integrados às políticas neoliberais”. Neste segundo grupo, estão as fundações empresariais, constituídas para atuar em programas sociais; e também ONGs "que passaram a incorporar atividades produtivas no trabalho com sua clientela".

Ao estabelecer o foco da pesquisa nas práticas educativas empreendidas pela sociedade civil no ambiente prisional, dois grupos de organizações merecem atenção especial: aquele que atua no campo da educação; e o grupo das organizações identificadas com a defesa dos direitos civis. 


\title{
4.2 Contestar a prisão
}

\subsubsection{Direitos humanos no Brasil}

A formulação e a concretização dos direitos humanos, bem com a designação de seus sujeitos, vêm sendo construídas historicamente por meio da relação, e tensão, entre sociedade e Estado. A evolução histórica dos direitos humanos ${ }^{115}$, para alguns autores e autoras, organiza-se em três gerações. A primeira geração corresponde aos direitos civis e políticos, que garantem as liberdades individuais. A segunda geração compreende os direitos econômicos e sociais, como direito à saúde, educação, moradia, cultura, lazer e os direitos trabalhistas. A terceira, é a dos chamados direitos dos povos, que corresponde ao direito ao desenvolvimento, à paz e a valores culturais próprios, entre outros (GENEVOIS, 1988, p.16-17).

Para Comparato (1989), a diferença entre as duas primeiras gerações de direitos humanos está no papel que o Estado desempenha em cada uma delas.

\begin{abstract}
A diferença específica entre essas duas gerações de direitos humanos é de primeira intuição: enquanto o respeito às liberdades supõe a não interferência estatal na esfera da vida própria do ser humano, seja individualmente, seja em grupos sociais, a realização daquelas prestações sociais implica, ao contrário, uma sistemática intervenção do Estado nas relações privadas, limitando a liberdade individual ou grupal. Assim as liberdades são, basicamente, direitos humanos contra a ação estatal, ao passo que a exigência de prestações sociais se dirige contra a omissão do Estado. (COMPARATO, 1989, p. 95).
\end{abstract}

O autor também salienta a vinculação intrínseca entre direitos humanos e Estado:

[...] desde as primeiras formulações teóricas modernas, na Europa Ocidental do século VIII, os direitos humanos apareceram estreitamente vinculados ao Estado. Mas uma vinculação, contraditoriamente, positiva e negativa ao mesmo tempo. [...] O Estado moderno aparece assim, concomitantemente, desde o seu nascimento, como o protetor e o principal adversário dos direitos humanos. (COMPARATO, 1989, p. 96).

O Brasil, como signatário de declarações e pactos internacionais de proteção aos direitos humanos, e tendo inscrito a educação, ao lado de outros direitos sociais, na Constituição Federal, além de regulamentá-los por uma série de leis de diretrizes, normas técnicas e outros instrumentos normativos, conferiu-lhe a condição de exigibilidade e

\footnotetext{
${ }^{115}$ A organização dos direitos humanos em "gerações" é repudiada por alguns autores (MUÑOZ, 2005, p.7) por trazer, implicitamente, a noção de "hierarquia" ou "evolução" entre os direitos, contrariando o princípio da indivisibilidade. Sem desconsiderar este debate, esta organização é aqui utilizada como meio de compreensão histórica da relação entre sociedade e Estado na conquista e afirmação dos direitos.
} 
justiciabilidade. Assim, sua efetivação por meio de políticas públicas pode ser exigida aos órgãos executivos das três esferas do governo nacional, inclusive acionando os instrumentos de garantia e proteção de direitos que integram o sistema jurídico do País, além do internacional.

Para Lima Jr. (2001), no Brasil, a pressão sobre o Estado, tendo como referência as possibilidades contidas na noção contemporânea de direitos humanos, vem ocorrendo desde a década de 1980.

\begin{abstract}
As organizações da sociedade civil vêm desenvolvendo estratégias de reivindicação dos DESC (direitos econômicos sociais e culturais), através de três mecanismos: a justiciabilidade - enquanto possibilidade de se exigir direitos face ao Poder Judiciário -, as políticas públicas e o monitoramento. (LIMA JR, 2001, p. 85-86).
\end{abstract}

A proposição acima parte da constatação de que a inscrição em leis, nacionais e internacionais, por si só não significa a efetivação de direitos, tampouco o reconhecimento, por parte do Estado, de seus sujeitos. No entanto, a formalização dos direitos fornece mais um elemento de pressão contra a omissão do Estado em relação à concretização dos direitos econômicos, sociais e culturais: a disputa judicial.

A sociedade civil se mobiliza para que os direitos sejam inscritos em leis, obrigando o reconhecimento formal por parte do Estado; depois, pressiona para que as leis sejam cumpridas; e, ainda, deve monitorar para que este cumprimento seja efetivado de maneira adequada, sem a mutilação dos direitos. Este processo é marcado por tensões com o Estado e também entre os grupos sociais, em virtude de seus interesses conflitantes. E é justamente neste contexto de disputas que a noção de universalidade é historicamente constituída - a definição sobre quem está contido no "universal" é, eminentemente, o resultado de lutas sociais.

Dalmo Dallari (2004), ao traçar um breve histórico da temática dos direitos humanos no Brasil, considera que as décadas de 1950 e 1960 são marcos iniciais, constituídos pela influência da Declaração Universal dos Direitos Humanos de 1948, e as orientações que marcaram a atuação da igreja católica a partir do Concilio Vaticano II (1962-1965), que trouxe consigo a Teologia da Libertação e a atuação comunitária nas Comunidades Eclesiais de Bases.

Também a Revolução Cubana, segundo o autor, estimulou as reflexões sobre os direitos e suas violações "sobretudo por demonstrar que um pequeno povo, determinado e 
suficientemente organizado, poderia se opor a uma grande potência e fazer cessar as injustiças que o flagelavam [...]” (DALLARI, 2004, p. 22).

Tais influências resultaram, ou se somaram, internamente, à iniciativa das Ligas Camponesas, estimuladas pelas ideias de Paulo Freire e sua Pedagogia da Libertação. "Descobria-se, assim, no Brasil, a relevância da ação conjunta, da livre associação e da organização social" (2004, p. 23).

O golpe militar identificou as reflexões sobre direitos humanos, estimuladas por estes grupos, com os ideais comunistas, passando a perseguir e reprimir arbitraria e violentamente seus integrantes.

Diante da violenta repressão do Estado contra grupos e indivíduos, pessoas de diferentes origens sociais se aglutinaram em grupos de defesa dos direitos humanos "em benefício daqueles perseguidos por suas convicções ou por sua militância política, presos, torturados, assassinados, exilados, banidos e, até hoje, considerados "desaparecidos" (BENEVIDES, 2004, p. 48).

De acordo com Maria Victoria Benevides, terminada a ditadura militar, o marco da defesa dos direitos humanos não incorporou os setores da classe média que se mobilizaram em favor de seus parentes e amigos vítimas da repressão. "Os defensores dos direitos humanos perderam a compreensão e o apoio que tinham da sociedade, pois passaram a se preocupar com a violação dos direitos de todos, sobretudo daqueles mais esquecidos, os presos comuns" (BENEVIDES, 2004, p.49).

Para a autora, depois da defesa dos presos políticos, se estabeleceu uma "diferenciação profunda e cruel entre ricos e pobres, entre intelectuais e iletrados, entre a classe média e a classe alta de um lado, e as classes populares de outro", uma vez que as pessoas responsabilizadas por crimes pertencem, em sua "maioria esmagadora às classes populares". Assim, a atuação dos grupos de direitos humanos "por ignorância ou má-fé" (BENEVIDES, 2004, p. 49) passou a ser associada apenas à defesa de criminosos, "fazendo-se confundir defesa da dignidade humana com promoção da criminalidade" (DALLARI, 2004, p.24).

A omissão do Estado em relação à concretização dos direitos das pessoas encarceradas, por sua vez, encontra respaldo na sociedade em geral, conforme citado por Benevides (2004), ao discorrer sobre o afastamento dos setores da classe média da mobilização pelo respeito aos direitos humanos, atualmente identificados como "direitos de bandidos". 
Pouca ou nenhuma visibilidade social tem o trabalho desenvolvido por organizações da sociedade civil que admitem como missão a defesa dos direitos humanos de pessoas encarceradas - exceto em ocasiões em que se quer desqualificar sua atuação, como forma de incitar a sociedade a admitir o endurecimento das punições como resposta a crimes que ganham destaque na mídia.

\subsubsection{Construção da insensibilidade}

A aparente, ou real, insensibilidade da sociedade em relação à prisão pode ser interpretada como parte do processo civilizador das práticas de punição, identificado por Garland (1995, p. 284 apud SALLA, 2006, p. 342). Da mesma forma que o autor afirma haver um processo civilizador das sensibilidades, que compreende, em alguns momentos históricos, a indignação da sociedade contra os sofrimentos impostos na prisão, que termina por resultar em mudanças nas políticas penitenciárias, no sentido de humanizá-las, também acontece o contrário.

E, neste contrário, há o processo civilizador das práticas de punição, marcado pelo abrandamento na forma de executar e apresentar a punição.

Penas ao corpo, causando dor física, deixa de ser um instrumento de punição e dá lugar a outras formas de sofrimento, como a privação da liberdade ou a cassação de recursos financeiros, ou, mais recentemente, a pena de morte por meio de uma injeção letal em vez da cadeira elétrica. O mesmo acontece com a linguagem referente às práticas punitivas, cujos termos assumem formas mais sutis de dizer a mesma coisa. (GARLAND, 1995, p. 284 apud SALLA, 2006, p. 342).

Para Garland, este processo cumpre a função de "tirar da esfera pública a percepção do sofrimento dos condenados" (1995, p. 243 apud SALLA, 2006, p. 342) ${ }^{116}$,

Porque o público não escuta a angústia dos prisioneiros e suas famílias, porque o discurso da mídia e da criminologia popular apresenta os criminosos como "diferentes", e menos que totalmente humanos, e porque a violência das penas é geralmente sanitária, situacional e de pouca visibilidade, o conflito entre as sensibilidades civilizadas e a frequentemente brutal rotina da punição é minimizada e feita tolerável. A punição moderna, portanto, é ordenada institucionalmente e representada em um discurso que nega a violência inerente das suas práticas.

\footnotetext{
${ }^{116}$ GARLAND, David. Punishment and modern society: a study in social theory. Oxford. Claredon Press. 1995.
} 
As considerações desses autores sobre o "processo civilizador" da apresentação da punição revelam procedimentos absolutamente racionais. $\mathrm{O}$ vocabulário oficial das prisões no Brasil é repleto das sutilizas apontadas por Salla (2006). As pessoas não estão presas ou encarceradas, mas, sim, privadas de liberdade, termo que induz à interpretação de que elas continuam a exercer os demais direitos, e apenas a liberdade lhes foi suprimida. Funcionários e gestores as chamam de reeducandas, ainda que, como demonstrado neste trabalho e em outras pesquisas, poucas são as condições para a realização de práticas de educação formal e não formal, deixando um campo imenso para a educação informal, em que, como demonstrado anteriormente, destacam-se a aprendizagem da submissão, tanto às regras das equipes oficiais de segurança quanto das normas dos grupos e lideranças da população carcerária.

Também, a apresentação das pessoas presas como "menos que totalmente humanos" (GARLAND, 1995; FOUCAULT, 2006) conta com um interessante aparato que envolve a mídia, mas também parlamentares e profissionais do campo do Direito, entre outros atores. Não se trata da criação de fatos, mas da forma como eles são transmitidos à população e repercutidos entre especialistas, vítimas e possíveis vítimas (GARLAND, 2008) ${ }^{117}$.

Christie (1998), refletindo sobre as prisões e outros mecanismos de controle sobre grupos indesejáveis, socialmente apresentados como "menos que totalmente humanos", recorre às análises de Bauman (1989) sobre as condições que viabilizaram a criação e o funcionamento dos campos de extermínio da Segunda Guerra Mundial.

Dois aspectos das análises de Bauman (1989) são essenciais para a compreensão da relação estabelecida entre sociedade e prisão. O primeiro deles é a racionalidade que marcou a produção dos campos de extermínio. Ao contrário de reflexões anteriores, que atribuíram a monstruosidade do extermínio nazista a mentes anormais ou a um sistema político autoritário, portanto, anormal, o autor demonstra que a criação e o funcionamento dos campos de extermínio só foi possível porque organizados por um aparato absolutamente racional, baseado em conhecimentos técnicos e científicos de várias áreas, notadamente, da Medicina entre outras atribuições, os médicos eram responsáveis por definir o destino dos prisioneiros, indicando aqueles que deveriam seguir imediatamente para a morte e aqueles que tinham condições físicas para serem aproveitados em diferentes serviços, antes da câmara de gás; da química - o gás utilizado nos campos era o inseticida desenvolvido para a agricultura; e do comércio - não foram desprezíveis os cálculos de produção e consumo de gás, tanto que ao

\footnotetext{
117 O noticiário brasileiro está repleto de exemplos que ilustram esta racionalização na produção da diferença entre sociedade e criminosos. Sobre o tema, ver NASCIMENTO, 2008.
} 
fim da Segunda Guerra, depois de uma breve prisão, os sócios da empresa responsável pela produção do gás tornaram-se consultores de grandes empresas.

O segundo aspecto, que Christie (1998) denomina de "a parte central da explicação do Holocausto de Bauman" é a "produção social da indiferença moral nas sociedades modernas” (BAUMAN, 1989 apud CHRISTIE, 1998, p. 173) ${ }^{118}$, e explica:

\begin{abstract}
Esta indiferença nasceu da autorização da rotina, e da desumanização das vítimas através de doutrinas e definições ideológicas. [...] A burocratização foi essencial nesse processo. [...] Ao ser tão implacável, a operação harmonizou-se com os elementos básicos do processo civilizatório, caracterizado pela implacável eliminação da violência da vida social. Ou, acrescenta Bauman, um processo caracterizado pela concentração da violência sob o controle do Estado (BAUMAN, 1989 apud CHRISTIE, 1998, p. 174-175).
\end{abstract}

Christie concorda com Bauman: a ideia de extermínio não foi uma invenção da Alemanha da Segunda Guerra Mundial, mas, sim, "parte de uma velha tradição": "O Holocausto é apenas a continuação de uma das principais tendências da história colonial europeia" (1998, p. 175). Tradição esta que se mantém por meio dos mecanismos de controle das populações indesejáveis adotados, notadamente nos Estados Unidos, e de lá exportados para outros países. Certamente não há a "matança legalizada" ou a "matança médica" (CHRISTIE, 1998), como na Segunda Guerra, mas o processo da produção social da indiferença moral, a autorização da rotina e a afirmação da necessidade de eliminar a violência da vida social são elementos presentes nas sociedades em geral.

Garland (2008), ao refletir sobre o fim do previdenciarismo penal nos Estados Unidos e na Inglaterra, se interroga por que a classe média, que no período anterior defendia a extensão de serviços e garantias sociais aos presos, não defendeu este sistema, ao contrário, passou a demandar maior controle e endurecimento das punições. E considera que não apenas a crise no mercado de trabalho estimulou o enfraquecimento da solidariedade para com a população carcerária.

O autor descreve uma série de mudanças nos hábitos econômicos, sociais e culturais naquelas sociedades, que gerou na classe média a sensação de medo e insegurança permanentes.

Entre essas mudanças, cita o padrão de consumo, com o incrível aumento dos bens móveis, como carros; a alteração na ocupação do espaço urbano, marcada pela retirada da classe média para regiões afastadas dos centros da cidade; e o fim das relações comunitárias,

${ }^{118}$ BAUMAN, Zygmeunt. Modernity and the Holocaust. Grã-Bretanha, 1989. 
baseada no conhecimento entre as pessoas que habitavam uma mesma localidade, constituindo um campo propício ao controle informal das ações dos indivíduos.

Todas estas transformações, aliadas à crise do mercado de trabalho e ao fim das garantias sociais, provocou, ao mesmo tempo, a ampliação dos crimes contra o patrimônio e a aproximação da classe média da violência, antes um fenômeno restrito aos pobres.

Conforme Garland, é a sensação de medo e insegurança, devidamente alimentada por políticos e pela mídia, que provoca na classe média, de um lado, a indiferença para com a situação da população carcerária e, de outro, a busca desenfreada por segurança, seja adquirindo equipamentos ou autorizando e apoiando ações de endurecimento do controle do crime, seja pelo Estado ou por aparatos privados: tanto faz - o que importa é buscar a sensação de que a violência não atingirá sua família nem seus bens materiais.

É preciso lembrar permanentemente que o Brasil não viveu nada parecido ao Estado de Bem-Estar Social, consequentemente, o previdenciarismo penal nunca existiu por aqui. Mas como já apontado anteriormente, elementos das políticas de segurança pública norteamericana influenciam as ações nacionais, e a disseminação do medo e da insegurança é uma realidade inegável, o que torna as reflexões de Garland essenciais para interpretar a indiferença da classe média para com a população carcerária no período de democratização do País, conforme identificado por Benevides (2004) e Dallari (2004).

E é interessante notar que este afastamento ocorre justamente quando normas propõem a participação da sociedade na vida pública em geral, como apontado anteriormente, e na promoção dos direitos humanos, inclusive no sistema prisional, em particular.

\subsection{Múltiplas expectativas}

\subsubsection{A ausência assinalada}

"A sociedade civil é a grande ausente na prisão". Dois gestores entrevistados pronunciaram exatamente esta mesma frase e concordaram que há espaços para a participação da sociedade na gestão da prisão, o que não ocorre por omissão da própria sociedade.

No entanto, os dois divergem quanto a qual deveria ser esta participação. Um deles afirma que organizações não governamentais deveriam atuar na oferta de cursos, sobretudo de profissionalização, e deveriam colaborar com o processo de reintegração social, abrindo vagas para a contratação de egressos. Avalia que o Estado não pode arcar com os custos do 
encarceramento sozinho e que deveria haver solidariedade por parte da sociedade, para assegurar melhores condições de vida na prisão.

O segundo, que já não atua mais na administração pública, tendo sido um dos responsáveis pelo processo de elaboração do Plano Estadual de Direitos Humanos, afirma não se lembrar de organizações da sociedade civil na defesa dos direitos das pessoas encarceradas, além da Pastoral Carcerária. Diz que essa ausência dificulta as ações dos gestores no sentido de humanizar o cárcere, em virtude das resistências internas à prisão. Quanto à educação, afirma nunca ter recebido nenhuma demanda pela realização de atividades formais ou não formais; justifica que as poucas pessoas preocupadas com a garantia dos direitos dos presos estão por demais absortas na tentativa de garantir a integridade física e moral da população e, neste contexto, a educação aparece como "perfumaria".

Há, nesses dois posicionamentos, uma nítida divergência sobre o papel da sociedade em relação à prisão, o que, consequentemente, induz à divergência do papel do Estado. Para o primeiro, é legítimo que organizações da sociedade assumam o papel de promotoras de ações garantidoras de direitos, como o acesso ao trabalho ou à educação, ocupando assim o lugar do Estado, que exerceria apenas a função regulatória.

$\mathrm{O}$ segundo posicionamento atribui à sociedade o papel de monitoramento e mobilização, para pressionar o Estado a cumprir seu dever e garantir direitos, ressaltando os direitos civis, e admitindo que os direitos coletivos, como a educação, nunca foram demandados.

O debate sobre a participação da sociedade civil nas ações de governos é intenso e tem sido tema de estudos ${ }^{119}$, além de debates promovidos por diferentes organizações ${ }^{120}$. Sobre o tema, Pontual (2007, p. 49) analisa: "Vivemos hoje um contexto em que as diversas correntes políticas e ideológicas da nossa sociedade disputam os sentidos atribuídos à participação e à democracia."

Sem desconsiderar a complexidade do tema, serão apresentadas a seguir reflexões sobre as formas de participação previstas em normas que regulam ou fazem referências ao sistema prisional e também às formas como as organizações da sociedade civil vêm atuando sobre o tema da educação em prisões, para além da promoção de atividades educativas.

\footnotetext{
${ }^{119}$ Cf.: DAGNINO (2002); COSTA (2002); PINHEIRO (1996).

${ }^{120}$ Cf.: $<$ http://www.abong.org.br>.
} 


\subsubsection{Ambiguidades normatizadas}

A divergência sobre o papel da sociedade na garantia dos direitos humanos, em geral, e na educação, em particular, não ocorre apenas entre gestores do espaço prisional, mas permeia as normas de direitos humanos em geral e aquelas relacionadas às instituições prisionais, em particular.

A Constituição Federal de 1988, elaborada durante o processo de abertura democrática que encerrou a ditadura imposta ao País com o golpe militar de 1964, está marcada, tanto na elaboração quanto no conteúdo, pela participação da sociedade civil.

A denominada "Constituição Cidadã" foi escrita em meio a um intenso processo de disputas de significados sobre a universalidade de acesso aos direitos, provocado pela afirmação de novos sujeitos reivindicando antigos direitos, e novos direitos sendo pautados.

Nesse contexto, o documento contemplou grande parte dessas reivindicações ao estabelecer a universalidade no acesso aos direitos civis, políticos, econômicos, sociais, culturais e ambientais. E foi além: estabeleceu mecanismos de controle social destinados à elaboração, gestão e monitoramento das políticas públicas que deveriam concretizá-los.

A ideia de que a participação social nos espaços públicos fortalece a democracia, contida na Constituição Federal, foi reproduzida em normas que regulam políticas de campos específicos da gestão pública. Não há, ainda, no Brasil, normas específicas que regulem a atuação da sociedade civil na educação realizada nas prisões, mas existem leis e outros instrumentos normativos de diferentes instâncias da Federação, como planos e programas de direitos humanos, que garantem a participação de instituições não governamentais na formulação, monitoramento e, algumas vezes, até na execução de ações desenvolvidas no ambiente prisional, conforme demonstrado a seguir.

\subsubsection{Programa Nacional de Direitos Humanos}

Na Introdução da primeira edição do Programa Nacional de Direitos Humanos, lançada em 1996, o governo federal admite a indivisibilidade dos direitos humanos, mas antecipa que, para tornar o plano "exequível", optou por definir "objetivos precisos", e então anuncia: “Assim, sem abdicar de uma compreensão integral e indissociável dos direitos humanos, o Programa atribui maior ênfase aos direitos civis, ou seja, os que ferem mais diretamente a integridade física e o espaço de cidadania de cada um”(PNDH - I, 1996, p. 4). 
O texto admite que a sociedade brasileira é injusta, com "graves desigualdades de renda", e que a "promoção dos direitos humanos tornar-se-á mais factível se o equacionamento dos problemas estruturais [...] for objeto de políticas governamentais", sem identificar, porém, a situação descrita como de violação aos direitos humanos.

$\mathrm{Na}$ sequência, depois de apontar a responsabilidade do Estado na implementação de políticas públicas, o texto justifica o fato desta primeira edição do Programa contemplar apenas os direitos civis e políticos, por eles serem a condição para que a sociedade civil possa exigir os demais direitos:

\begin{abstract}
Mas, para que a população possa assumir que os direitos humanos são direitos de todos, e as entidades da sociedade civil possam lutar por esses direitos e organizar-se para atuar em parceria com o Estado, é fundamental que seus direitos civis elementares sejam garantidos e, especialmente, que a Justiça seja uma instituição garantidora para qualquer um. (PNDH - I, 1996, p. 5).
\end{abstract}

Em diversos momentos, o texto afirma a necessidade da participação da sociedade civil na implementação do PNDH:

O Programa contempla, igualmente, iniciativas que fortalecem a atuação das organizações da sociedade civil, para a criação e consolidação de uma cultura de direitos humanos. Nada melhor para atingir esse objetivo do que atribuir a essas organizações uma responsabilidade clara na promoção dos direitos humanos, especialmente nas iniciativas voltadas para a educação e a formação da cidadania. (PNDH - I, 1996, p. 5).

Destaca-se que o texto atribui à sociedade civil o papel de "promotora" dos direitos humanos, quando, como já apontado anteriormente, na concepção contemporânea de direitos humanos esta é uma prerrogativa do Estado, por meio da efetivação de políticas públicas.

Ao final de sua Introdução, o documento resgata o processo de construção do Programa, elaborado com base nos seminários regionais realizados em São Paulo, Rio de Janeiro, Recife, Belém, Porto Alegre e Natal, com 334 participantes, pertencentes a 210 entidades. Também informa que foram feitas consultas por telefone e fax a centros de direitos humanos e personalidades e, finalmente, que o texto foi apresentado na I Conferência Nacional de Direitos Humanos, organizada pela Comissão de Direitos Humanos da Câmara Federal, em abril de 1996, com a participação de centenas de representantes de organizações da sociedade civil de todo o País. "Neste processo de elaboração foi colocada em prática a parceria entre o Estado e as organizações da sociedade civil. Na execução concreta do Programa, a mesma parceria será intensificada”, conclui o documento. 
Na segunda edição do programa, lançada em 2002, o texto de introdução afirma que as alterações feitas no documento resultaram da reivindicação da sociedade civil:

O processo de revisão do PNDH constitui um novo marco na promoção e proteção dos direitos humanos no País, ao elevar os direitos econômicos, sociais e culturais ao mesmo patamar de importância dos direitos civis e políticos, atendendo a reivindicação formulada pela sociedade civil por ocasião da IV Conferência Nacional de Direitos Humanos, realizada em maio de 1999, na Câmara dos Deputados, em Brasília. (PNDH- II, 2002, Introdução).

$\mathrm{O}$ PNDH - II incorporou ações específicas no campo da garantia do direito à educação, à saúde, à previdência e assistência social, ao trabalho, à moradia, a um meio ambiente saudável, à alimentação, à cultura e ao lazer. Também foram alterados os mecanismos de monitoramento das ações:

Atendendo a anseios da sociedade civil, foram estabelecidas novas formas de acompanhamento e monitoramento das ações contempladas no PNDH, baseadas na relação estratégica entre a implementação do programa e a elaboração dos orçamentos em nível federal, estadual e municipal. (PNDH- II, 2002, Introdução).

Coube à Secretaria Especial de Direitos Humanos o lançamento da terceira versão do Programa Nacional de Direitos Humanos (SEDH, 2010), ocorrido em dezembro de 2009, no qual se afirma a responsabilidade do Estado sobre a realização das ações necessárias à garantia dos direitos humanos, e confere à sociedade civil o papel de corresponsável pela formulação das políticas do campo e lhe atribui a responsabilidade sobre o monitoramento de sua efetivação.

A adoção de tais medidas fortalecerá a democracia participativa, na qual o Estado atua como instância republicana da promoção e defesa dos Direitos Humanos e a sociedade civil como agente ativo - propositivo e reativo - de sua implementação. (SEDH, 2010, p. 22).

O programa, que é estruturado em seis eixos orientadores ${ }^{121}$, dedica um deles - o primeiro - à relação Estado e sociedade civil, que é assim justificada:

Compreendendo que todos os agentes públicos e todos os cidadãos são responsáveis pela efetivação dos Direitos Humanos no país, o tema da Interação Democrática entre Estado e Sociedade Civil abre o Programa. O compromisso compartilhado e a participação social na construção e monitoramento das distintas políticas públicas

\footnotetext{
${ }^{121}$ O PNDH - 3 é estruturado nos seguintes eixos orientadores: Interação Democrática entre Estado e Sociedade Civil; Desenvolvimento e Direitos Humanos; Universalizar Direitos em um Contexto de Desigualdades; Segurança Pública, Acesso à Justiça e Combate à Violência; Educação e Cultura em Direitos Humanos; Direito à Memória e à Verdade.
} 
são essenciais para que a consolidação dos Direitos Humanos seja substantiva e portadora de forte legitimidade democrática. O PNDH-3 propõe a integração e o aprimoramento dos fóruns de participação existentes, bem como a criação de novos espaços e mecanismos institucionais de interação e acompanhamento. (SEDH, 2010, p. 18).

Todos os eixos anunciam estratégias que compreendem mecanismos de monitoramento, prevendo ações relacionadas ao acesso às informações públicas das respectivas áreas ${ }^{122}$. Considerando que o texto do programa foi construído com base nas propostas elaboradas em processos de realização de 50 Conferências (SEDH, 2010, p. 18) de diversas áreas, o que significou o envolvimento de centenas de organizações da sociedade civil de diferentes áreas, a insistência na divulgação dos dados públicos revela o que tem sido o principal entrave à atuação da sociedade civil no acompanhamento da situação das políticas de direitos humanos em geral, e da segurança pública em particular, destacadamente, do sistema prisional.

Dessa forma, o texto responsabiliza diferentes órgãos de governos a produzir e disseminar informações tanto sobre o diagnóstico das demandas, quanto da implementação das políticas formuladas. O tema das prisões é tratado no eixo "Segurança pública, acesso à justiça e combate à violência”, e as ações previstas para assegurar a participação da sociedade civil na formulação e acompanhamento das políticas são:

\footnotetext{
${ }^{122}$ Ações previstas para viabilizar o monitoramento das políticas de Direitos Humanos (2009): Apoiar, junto ao Poder Legislativo, a instituição do Conselho Nacional dos Direitos Humanos e estimular a constituição de seus correlatos em âmbitos estadual e municipal (p. 24); Criar base de dados dos conselhos nacionais, estaduais, distrital e municipais, garantindo seu acesso ao público em geral (p. 25); Apoiar fóruns, redes e ações da sociedade civil que fazem acompanhamento, controle social e monitoramento das políticas públicas de Direitos Humanos (p. 25); Estimular o debate sobre a regulamentação e efetividade dos instrumentos de participação social e consulta popular, tais como lei de iniciativa popular, referendo, veto popular e plebiscito; Publicação de dados do sistema federal de segurança pública (p. 25); Assegurar a realização periódica de conferências de Direitos Humanos, fortalecendo a interação entre sociedade civil e poder público (p. 25); Ampliar a divulgação dos serviços públicos voltados para a efetivação dos Direitos Humanos, em especial; nos canais de transparência (p. 26); Propor a instituição da Ouvidoria Nacional dos Direitos Humanos, em substituição à Ouvidoria-Geral da Cidadania, com independência e autonomia política (p. 26); Criar o Observatório Nacional dos Direitos Humanos para subsidiar, com dados e informações, o trabalho; de monitoramento das políticas públicas e de gestão governamental (p. 28); Estimular e reconhecer pessoas e entidades com destaque na luta pelos Direitos Humanos na sociedade brasileira e internacional (p. 28); Instituir e manter sistema nacional de indicadores em Direitos Humanos, de forma articulada com os órgãos públicos e a sociedade civil (p. 29); Integrar os sistemas nacionais de informações para elaboração de quadro geral sobre a implementação de políticas públicas e violações aos Direitos Humanos (p. 29); Articular a criação de base de dados com temas relacionados aos Direitos Humanos (p. 29); Utilizar indicadores em Direitos Humanos para mensurar demandas, monitorar avaliar, reformular e propor ações efetivas (p. 29); Propor estudos visando a criação de linha de financiamento para a implementação de institutos de pesquisa e produção de estatísticas em Direitos Humanos nos Estados (p. 29); Produzir relatórios de acompanhamento dos direitos humanos no Brasil, em cooperação com a sociedade civil, inclusive para ser encaminhado ao sistema internacional de justiça (p. 30); Definir e institucionalizar fluxo de informações, com responsáveis em cada órgão do Governo Federal e unidades de Federação, referentes aos relatórios internacionais de Direitos Humanos e criar banco de dados público sobre as respectivas recomendações (p. 30-31).
} 
Reformular o conselho nacional de justiça para garantir participação da sociedade civil (p. 109); Fortalecer a Ouvidoria do Departamento Penitenciário Nacional, dotando-a de recursos humanos e materiais necessários ao desempenho de suas atividades, propondo sua autonomia funcional (p. 122); Elaborar projeto de lei visando a instituir o Mecanismo Preventivo Nacional, sistema de inspeção aos locais de detenção para o monitoramento regular e periódico dos centros de privação de liberdade (p.127); Avançar na implementação do Sistema de Informações Penitenciárias (InfoPen), financiando a inclusão dos estabelecimentos prisionais dos estados e do Distrito Federal e condicionando os repasses de recursos federais à sua efetiva integração ao sistema (p. 137); Implementar o Observatório da Justiça Brasileira, em parceria com a sociedade civil; Desenvolver sistema integrado de informações do Poder Executivo e Judiciário e disponibilizar seu acesso à sociedade. (SEDH, 2010, p. 147).

A formulação de cada uma das três versões do Programa Nacional de Direitos Humanos reflete a conjuntura social de sua elaboração. A primeira versão atribui à participação da sociedade civil um papel tão central na promoção e garantia de direitos humanos que chega a substituir o Estado. Afirmar que a garantia dos direitos civis e políticos cria as condições para a efetivação dos econômicos, sociais, culturais e ambientais porque possibilita que a sociedade se mobilize para exigir, significa isentar o Estado de qualquer responsabilidade pela promoção de políticas de garantia de direitos humanos. A desresponsabilização do Estado é absoluta se considerada a característica dos direitos civis e políticos de se efetivarem justamente pela omissão do Estado (COMPARATO, 1989; LIMA JR, 2000; PIOVESAN, 2002).

Essa formulação é coerente com o processo de reforma do Estado, promovido no Brasil nos anos 1990 (HADDAD, 2003a), e que Garland (2008) e Rose (1996) narram ter se iniciado nos Estados Unidos e países da Europa já na década de 1980. O objetivo foi reduzir a presença do Estado da vida social e econômica, ao mesmo tempo em que se estimulava o protagonismo da sociedade civil em diversos campos de atuação. O Estado assumiu o papel de provocar e regular iniciativas de grupos organizados e também de pessoas (ROSE, 1996).

No Brasil, Gohn (2008) lembra que é nesta conjuntura de redução da presença do Estado na garantia de políticas universais e de reconfiguração do mundo do trabalho, com crescimento da economia informal, que vem se constituindo a "economia social", promovida por organizações da sociedade civil, reunidas no chamado terceiro setor, com base em formas de associativismo:

O associativismo do terceiro setor é pouco ou nada politizado, na maioria das vezes avesso às ideologias, e integrado às políticas neoliberais [...] $\mathrm{A}$ economia social incorpora critérios e procedimentos do capitalismo. "O governo federal tem colaborado com recursos financeiros nos projetos de parceria. Grande contribuição governamental tem sido na área jurídica, de regulamentação de novas regras para o 
trabalho voluntário, regulamentando formas de trabalho sem vínculos empregatícios por períodos superiores a 90 dias. (GOHN, 2008, p. 79).

Dessa forma, o Programa reflete a ideia de protagonismo da sociedade, em substituição das obrigações estatais. A responsabilidade recai sobre os indivíduos, que devem se organizar para efetivar os demais direitos.

Essa é uma forma de efetivação de direitos particularmente cruel para a população carcerária, pois quem seriam os atores sociais dispostos a atuar na defesa de seus interesses? Como demonstrado anteriormente, o tema não tem sensibilizado a sociedade no período da democracia.

A segunda versão do Programa, lançada em 2002, afirma incorporar os direitos econômicos, sociais, culturais e ambientais por demanda e pressão da sociedade civil. Afirma a responsabilidade do Estado na promoção e garantia dos direitos humanos, mas também a necessidade de que esta seja partilhada com a sociedade civil. Mas os termos desta partilha não estão explícitos, tanto assim que os gestores citados anteriormente partem dessa premissa para chegar a posições bastante diferenciadas quanto ao papel do Estado e da sociedade civil em relação às prisões.

Já a terceira versão do Programa reflete uma dimensão que vem sendo tema de debate entre organizações da sociedade civil e movimentos sociais: a participação tem limites, e muitos.

De um lado, há o risco de precarizar a execução de ações previstas em políticas públicas, quando a sociedade civil aceita tomar o lugar do Estado e agir como empresas terceirizadas. De outro, os sistemas descentralizados e participativos criados por determinação constitucional, como os conselhos de gestão e as conferências das diferentes áreas, ainda não foram avaliados sob o ponto de vista da sua eficácia em relação aos seus objetivos e também não há balanços sobre o grau de incorporação das demandas e recomendações apresentadas nesses espaços (PONTUAL, 2007, p. 49-50).

São vários os relatos, nas diferentes áreas, que indicam a falta de condições para a atuação da sociedade civil nos conselhos, seja por falta de infraestrutura, conhecimento técnico ou manipulação política por parte dos gestores.

Sempre considerando que as três versões do programa nacional de direitos humanos foram elaboradas em processos que contaram com a participação de diferentes grupos da sociedade civil, incluindo movimentos sociais, é coerente que o texto seja permeado de ações que visem a fortalecer espaços de monitoramento e gestão já existentes, bem como garantir que os órgãos governamentais viabilizem sua atuação, por meio da garantia de estrutura e do 
acesso a informações. Trata-se, talvez, de uma postura menos ingênua, que no período anterior levou alguns setores da sociedade a acreditarem que bastava a existência de espaços e a presença de agentes não estatais neles para assegurar que existiriam políticas públicas que garantissem a efetivação de direitos para a maioria da população.

Lembrando as advertências de Garland (2008) sobre os cuidados que se deve ter ao analisar fatos e conjunturas do presente, é preciso assinalar que a redação da terceira versão do programa nacional de direitos humanos é muito recente, tendo sido apresentada no final de 2009. No momento da redação deste capítulo, o documento ainda está para ser apreciado pelo Congresso Nacional. Daí a necessidade de afirmar que seu conteúdo expressa, de um lado, o posicionamento de setores da sociedade civil organizada e, de outro, intenções formalmente assumidas por um governo, o que não significa que serão efetivadas. Para efeito deste trabalho, interessa particularmente a primeira perspectiva: o posicionamento da sociedade civil, que de acordo com o teor do texto, parece mais inclinada a monitorar as políticas em curso - e, para tanto, reclama informações - do que em partilhar responsabilidades na sua execução.

Por fim, é preciso ressaltar que todas essas considerações refletem uma síntese de debates, disputas e interesses que se manifestam em âmbito nacional. Isto não significa que reflita a realidade dos Estados.

No tocante à segurança pública, em geral, e ao sistema prisional, em particular, essa consideração é essencial, uma vez que a realidade dos Estados é bastante diversa entre si, produzindo diferentes atuações tanto do Estado como da sociedade civil.

\subsubsection{A participação no Estado de São Paulo}

O Estado de São Paulo lançou seu Plano de Direitos Humanos em 1997. Como a segunda versão do PNDH, o Plano Estadual de Direitos Humanos de São Paulo afirma e reafirma o estabelecimento de parcerias com a sociedade civil, tanto na elaboração quanto na implementação e monitoramento das ações previstas. O PEDH-SP foi elaborado com base nas propostas formuladas durante o $1^{\circ}$ Fórum Estadual de Minorias (1997), organizado pela Secretaria da Justiça e da Defesa da Cidadania e pelo Conselho Estadual de Defesa dos Direitos da Pessoa Humana, e nos encontros setoriais e seminários regionais, organizados pelo Núcleo de Estudos da Violência da Universidade de São Paulo. No total, participaram desse processo 461 organizações da sociedade civil, e o documento produzido foi debatido e 
reelaborado na $1^{\text {a }}$ Conferência Estadual de Direitos Humanos, realizada em junho de 1997, com a participação de 142 organizações, governamentais e da sociedade civil.

Quanto ao monitoramento das ações estabelecidas, o documento afirma que foi definido em "decreto do governador Mario Covas (15/9/1997)" como atribuição do Estado e da sociedade civil, "em conjunto".

No item denominado "Sistema prisional e ressocialização", o PEDH cita repetidas vezes a necessidade de parcerias entre Estado e sociedade civil na realização de diferentes ações e estratégias, descritas em diversos itens. Dessa forma, a sociedade civil é lembrada de, em parceria com o Estado: 1) desenvolver o aperfeiçoamento do sistema penitenciário (item 147); 2) desenvolver programas de identificação de postos de trabalho para cumprimento da pena de prestação de serviços à comunidade (item 149); 3) compor grupos de trabalho com a missão de melhorar o funcionamento da Vara de Execuções Criminais (item 153); 4) acompanhar programas de ressocialização e reeducação de presos (item 154); 5) facilitar o acesso à educação, ao esporte e à cultura, fortalecendo projetos como Educação Básica, Educação pela Informática, Telecurso 2000, Teatro nas Prisões e Oficinas Culturais (item 169); 6) promover programas de capacitação técnico-profissionalizante para os presos, possibilitando sua reinserção profisssional nas áreas urbanas e rurais (item 170); 7) desenvolver programas visando à absorção pelo mercado de trabalho de egressos do sistema penitenciário (item 171).

As atribuições da sociedade civil em relação ao sistema prisional paulista são variadas e indicam enorme expectativa em relação à sua atuação, sobretudo na execução de ações, embora também estejam previstas estratégias de monitoramento das ações.

A frustração dos gestores, esboçada anteriormente, é proporcional à ambição do Plano. As ações previstas são tão amplas, e a redação tão imprecisa, que é impossível identificar qual a real expectativa dos grupos que participaram da formulação do documento. Fica evidente, no entanto, que a reduzida responsabilização do Estado em relação ao sistema prisional.

No entanto, não é possível afirmar que a insistente chamada da sociedade civil seja apenas o reflexo da reforma do Estado, uma forma de omissão e redução dos gastos sociais. Havia também, no momento de sua formulação, compromisso tanto de setores do governo, quanto da sociedade civil, de respeito aos direitos humanos dos presos, e o Plano expressa esta tensão entre duas perspectivas diferenciadas sobre o papel da sociedade civil - a mesma diferença expressa pelos gestores citados anteriormente.

Se considerarmos que desde 1979 todos os governantes do Estado de São Paulo conseguiram eleger seus sucessores, e que as políticas penitenciárias mudaram 
substancialmente de caráter em relação à função e gestão das penas, pode-se afirmar que existem lógicas antagônicas que se manifestam em um mesmo governo, as quais alteram a relação entre sociedade civil e Estado no âmbito prisional.

Salla (2007) faz uma retrospectiva histórica da situação das prisões no Estado de São Paulo entre 1979 e 2006. Destaca o crescimento do encarceramento, e aponta os governos de Franco Montoro (1983-1986) e Mario Covas (1995-1998; 1999-2001) como aqueles que tentaram implementar políticas penitenciárias de respeito aos direitos humanos.

No governo Montoro, sob a responsabilidade do secretário de Justiça José Carlos Dias, diversas medidas foram adotadas no sentido de "humanizar os presídios" (TEIXEIRA, 2006), dentre as quais se destaca a constituição das Comissões de Solidariedade, que contava com a participação de presos e tinham por objetivo promover o diálogo entre a direção da unidade e os internos, porém, encontraram resistência dentro e fora das prisões, conforme demonstra Salla (2007) e relata Mendes (2001), interno do sistema prisional paulista por mais de 31 anos, que publicou obras biográficas em que narra a contrariedade dos funcionários em relação às novas normas de disciplina e suas consequências para o cotidiano dos presos.

O governo, primeiro eleito depois da ditadura militar, sofreu desgastes em razão das críticas de setores conservadores da sociedade e da imprensa; e, de outro lado, setores internos que não respeitavam as novas regras, produzindo atos de insubordinação que levavam a crer que o Estado perdera o controle (SALLA, 2007). O papel da imprensa, nesse período, também é descrito por Teixeira (2006, p. 80):

As forças que foram mobilizadas contra a política humanizadora de Dias tiveram sua
origem nesta casta do sistema penitenciário - os diretores e guardas dos presídios -,
mas logo arregimentariam um segmento importante da imprensa, representado em
especial pelo grupo "Estado" - os jornais O Estado de S. Paulo e Jornal da Tarde -
que se tornariam os principais porta-vozes de oposição à gestão do Secretário Dias.
(TEIXEIRA, 2006, p. 80).

Em razão das pressões, foram reconduzidos a cargos importantes antigos colaboradores do governo de Paulo Maluf, registrando assim um profundo retrocesso nas políticas penitenciárias, aprofundado nos governos de Orestes Quércia (1987-1990) e Luiz Antonio Fleury (1991-1994), em que se inicia a substituição de políticas de atenção à população carcerária pela construção de novas unidades prisionais e pela ação violenta da polícia. É desse período a morte, por asfixia, de 18 presos no $42^{\circ}$ Distrito Policial em São Paulo em 1989, e o massacre do Carandiru, em 1992. Quanto à ampliação do encarceramento: 
As principais medidas governamentais durante a gestão Quercia estiveram voltadas para a expansão da base física do sistema penitenciário, sendo criadas novas unidades, que tinham como preocupação clara evitar que novas rebeliões eclodissem e gerassem o desgaste político que esse mesmo setor provocou para o governador Franco Montoro. [...] Em 1983 o movimento médio anual nas unidades penitenciárias que integravam a Coespe havia sido de 9.972 presos. Em 1987, passou a ser de 14.988 presos e em 1990 chega a 23.516. Em 1992, ano em que ocorreu o Massacre do Carandiru, na Casa de Detenção de São Paulo, o movimento médio anual havia sido de 30.670 presos distribuídos em 43 unidades prisionais. (SALLA, 2007, p. 77).

Também neste período, em 1991, no governo Fleury, a gestão das penitenciárias, sob a responsabilidade da Coordenadoria dos Estabelecimentos Penitenciários do Estado (Coespe), foi transferida da Secretaria de Justiça para a de Segurança Pública, o que significou, para diferentes autores, mais uma iniciativa no sentido de endurecer, ou tornar mais violenta, a execução da pena, conforme demonstra o Massacre do Carandiru, resultado da intervenção da polícia no interior da Casa de Detenção.

Ao lado dessas iniciativas, essa gestão foi marcada pela existência de debates em torno da privatização do sistema penitenciário.

A geografia dos interesses presentes nas propostas envolvia empresas de segurança privada com o apoio de alguns políticos e policiais que defendiam publicamente a "necessidade" de o Estado reconhecer sua incapacidade para gerenciar eficazmente as prisões, passando evidentemente os recursos financeiros mal utilizados para quem sabia administrá-los, ou seja, para as empresas. (SALLA, 2007, p. 79).

O governo de Mario Covas (1995-1999) retoma algumas das ações de garantia de direitos humanos, contexto em que é formulado o Plano Estadual de Direitos Humanos, sem, contudo, conseguir frear a ampliação do encarceramento, que seguiu ritmo vertiginoso, sendo que em 1999 o sistema penitenciário contava com 21 unidades a mais que no ano anterior. Comprometeu-se com a implantação da Secretaria de Administração Penitenciária (SAP), e a possibilidade de privatização do sistema penitenciário não foi considerada, mas o tema, naquele período, foi recolocado pelo governo federal (SALLA, 2007, p. 79).

A gestão enfrentou intensa onda de rebeliões e fugas em diferentes unidades prisionais, e também foi neste período, 1997, que a imprensa noticiou pela primeira vez a existência do Primeiro Comando da Capital (PCC). Repetiram-se as críticas na imprensa, que ecoavam, mais uma vez, a opinião daqueles que atribuíam a insubordinação à atenção dada pelo governo aos presos e suas reivindicações.

Salla (2007, p. 86) relembra que entre a gestão Covas e Alckmin, ou, mais precisamente, até 2006, com a SAP sob a responsabilidade, respectivamente, de João 
Benedito de Azevedo Marques e Nagashi Furukawa, houve uma ampliação do diálogo do sistema penitenciário com as organizações não governamentais.

\begin{abstract}
Apesar dos obstáculos ainda existentes para o estreitamento da participação das ONGs no monitoramento das condições prisionais e na apresentação de propostas de melhoria da gestão dos estabelecimentos, diferentes tipos de organizações passaram a ter um acesso maior aos espaços prisionais para o trabalho religioso, para atividades educativas ou assistenciais, na área da saúde ou mesmo nos momentos de gerenciamento das crises. (SALLA, 2007, p. 86).
\end{abstract}

Para o autor, "uma nova relação com as ONGs" teve início em 1996, com a experiência da gestão da Cadeia Pública de Bragança Paulista, por meio da Associação de Proteção e Assistência Carcerária (Apac), estimulada pelo juiz local, Nagashi Furukawa, que mais tarde, já na condição de secretário de Estado, tentou disseminar este modelo de gestão por meio dos Centros de Ressocialização (CRs), implantados em diferentes cidades do interior paulista.

Teixeira (2006) relata que o modelo Apac, no Estado de São Paulo, foi criado na década de 1970, constituindo-se como organizações vinculadas a segmentos da Igreja Católica, cuja atuação "voltava-se ao trabalho de orientação religiosa e assistência material de caráter pontual, sendo a experiência de Bragança a primeira em que esse tipo de organização assumia um papel de cogestão na administração de um estabelecimento prisional" (TEIXEIRA, 2007, p. 142).

O modelo Apac, aplicado nos CRs, prevê unidades menores, que comportem cerca de 200 internos, nas quais organizações da sociedade civil assumem a responsabilidade pela garantia dos "serviços de assistência ao preso (judiciária, a saúde, social, atividades de trabalho e educação)" (2007, p. 86); e o Estado, por sua vez, é responsável pelo aparato de segurança e divide a direção geral com as entidades.

A experiência de cogestão entre sociedade civil e Estado das pequenas unidades prisionais paulistas é bastante controversa e divide opiniões. Há argumentos favoráveis à experiência, tanto pela organização física quanto pela gestão compartilhada com organizações da sociedade civil, que, segundo seus defensores, tornam o ambiente propício ao processo de ressocialização.

Mas há também críticas de diversas ordens. Teixeira (2006, p. 153) considera o modelo uma forma de terceirização das obrigações estatais, destinadas à redução de gastos. J., da Pastoral Carcerária, responsável pela elaboração de um relatório sobre o tema, avalia que o princípio estava correto, mas sua concretização encontrou limites de diversas ordens. $\mathrm{O}$ 
principal deles foi que as organizações que assumiram a gestão das unidades não existiam previamente, mas foram criadas, muitas vezes por familiares ou amigos de funcionários do sistema prisional, com a finalidade de gerir os CRs, com os devidos repasses de recursos públicos. "Começaram a criar as ONGs nas cidades, na verdade era um grupo de amigos que formava [a entidade] sem qualificação técnica, sem histórico", relatou $J$.

Apesar dos indícios de irregularidades na aplicação dos recursos identificados no relatório que produziu, $J$. considera que a desqualificação pública da gestão dos CRs realizada pela própria SAP posteriormente à saída de Nagashi Furukawa do governo, não foi baseada em um processo rigoroso de avaliação do modelo, mas fruto de disputas políticas internas no governo.

Furukawa deixou a SAP em 2006, depois de intenso desgaste provocado por sucessivos atos de violência, verificados em diferentes locais do Estado de São Paulo e atribuídos ao Primeiro Comando da Capital (PCC) (ADORNO; SALLA, 2007). Neste contexto, Lourival Gomes assumiu o cargo de secretário-adjunto da SAP, em 2006, retornando à secretaria, depois de, anos antes, ter sido demitido do cargo de coordenador da Coespe por Furukawa, em virtude de denúncias de irregularidades administrativas e conivência com práticas de tortura e maus-tratos aos presos (TEIXEIRA, 2006, p. 141).

Além de ficarem sob suspeita em razão das denúncias de irregularidade na administração dos CRs, em 2006, as ONGs também foram responsabilizadas pela onda de violência atribuída ao PCC. Durante a crise, algumas ONGs que atuavam no sistema penitenciário foram acusadas de atuar como porta-vozes de grupos criminosos organizados e de viabilizar negócios desses grupos. Nenhuma das ONGs acusadas tinha qualquer participação na gestão. [...] Na ocasião, o governador Claudio Lembo destacou que o papel das ONGs era "fiscalizar o governo e não viver dele" (SALLA, 2007, p. 87).

Após esse período, diferentes organizações e mesmo pessoas voluntárias que já atuaram nas prisões paulistas identificaram que a SAP promoveu o "fechamento" das prisões para a atuação da sociedade civil.

A., uma das responsáveis pela concretização do projeto "Promotoras Legais Populares" na PFC e entrevistada para este trabalho, avalia que seria "impossível" reproduzir a experiência nas atuais condições do sistema penitenciário paulista. De um lado, afirma que a atual gestão é a mais autoritária desde a ditadura militar, ressaltando que, durante o regime de exceção, São Paulo teve como secretário responsável pela gestão prisional o advogado Manoel Pedro Pimentel, reconhecidamente um defensor da função ressocializadora das penas. Atualmente, A. considera que o Estado abandonou o "ideal ressocializador" (GARLAND, 
2008, CHANTRAINE, 2006 e CHANTRAINE E MARY, 2006), e as prisões paulistas servem apenas para imobilizar seres humanos. Assim, mesmo que existissem direções de unidades dispostas a viabilizar a atuação de organizações da sociedade civil no cárcere, não poderiam fazê-lo nesse sentido, porque a gestão da secretaria as impediriam. De outro lado, atribui a impossibilidade da atuação de organizações da sociedade civil à forte atuação das facções criminosas "Teríamos que trabalhar com o consentimento e a participação dos ‘irmãos e irmãs' do Partido, e isto é muitíssimo complicado”, diz A..

J., da Pastoral Carcerária, concorda que houve um fechamento do sistema paulista e relata a dificuldade de acessar documentos oficiais. As solicitações não são negadas, mas também não são atendidas.

Depoimentos do juiz corregedor Octavio de Barros Filho, tornados públicos por meio do documentário "Entre a luz e a sombra", ${ }^{123}$ também identificam o fechamento das prisões à presença de grupos externos. Octavio de Barros Filho ganhou destaque público, no início da década de 2000, por autorizar a saída de grupos musicais constituídos dentro das prisões para a realização de apresentações e outros compromissos artísticos, e também por autorizar diversas atividades culturais no ambiente prisional, promovidas por grupos ou pessoas externas ao sistema. Depois de reações contrárias a esta prática por parte de parlamentares e órgãos da imprensa, foi compulsoriamente transferido de local de atuação. Tanto no documentário quanto durante os debates promovidos por ocasião de seu lançamento, em novembro de 2009, o juiz afirma que no atual contexto seria impossível atuar da mesma maneira, e que não há mais espaço para ações de ressocialização na prisão.

A constatação de que a atual conjuntura tornou-se mais adversa para a atuação da sociedade civil na prisão paulista não significa, no entanto, que nos anos anteriores tenha sido efetiva e realizada nos termos explícitos no Plano Estadual de Direitos Humanos, nem que o sistema paulista tenha sido administrado por princípios de afirmação da função ressocializadora da pena de prisão. Também, como já exposto em outros momentos deste trabalho, não viveu nada parecido com o "previdenciarismo penal" (Garland, 2008). O que houve foram algumas gestões comprometidas com o respeito aos direitos humanos, mas que encontraram forte resistência tanto interna quanto externamente, e tiveram que recuar.

O último período exposto, na gestão Nagashi Furukawa, foi marcado tanto pela apresentação do CRs como alternativa às penitenciárias superlotadas, como pela proposição do Regime Disciplinar Diferenciado (RDD), considerado incrivelmente violento por suspender direitos previstos na Lei de Execução Penal, mas também por lançar mão daquele

\footnotetext{
${ }^{123}$ Entre a luz e a sombra. Luciana Burlamaqui. 150 min. 2009.
} 
que é sabidamente a mais cruel das formas de prisão - o encarceramento solitário (RUSCHE; KIRCHHEIMER, 2004).

No aspecto normativo, apesar da extensa e variada expectativa contida no Plano Estadual de Direitos Humanos sobre a participação da sociedade civil, houve apenas duas únicas iniciativas do governo estadual no sentido de dar concretude à sua atuação, e ambas podem ser interpretadas como transferência de responsabilidades ou alternativa à frágil estrutura destinada a gestão das prisões.

A primeira iniciativa refere-se a Decretos ( ${ }^{o} 45.403$ de 16/11/2000, substituído pelo Decreto $N^{o} 47.840$, de 23/5/2003) e Resolução (SAP - 59, de 13/6/2003) que viabilizaram a cogestão dos CRs mediante a celebração de convênios com entidades privadas, sem fins econômicos, com transferência de recursos financeiros. A outra iniciativa são os decretos que regulam a atuação de estudantes de diferentes cursos de ensino superior na função de “estagiários" (Decreto $N^{0}$ 54.341, de 18/5/2009, que alterou o Decreto $N^{\circ} 47.169$, de 1\%/10/2002), objeto de análise no Capítulo 2 deste trabalho.

O Decreto que autoriza a celebração de convênios para a cogestão de unidades prisionais elenca, entre seus objetivos, cumprir o disposto no artigo $4^{\circ}$ da Lei de Execução Penal (Lei Federal 7.210/84): “O Estado deverá recorrer à cooperação da comunidade nas atividades de execução da pena e da medida de segurança". Poderia ter citado também que a mesma lei, no artigo 10, determina que "A assistência ao preso e ao internado é dever do Estado, objetivando prevenir o crime e orientar o retorno à convivência em sociedade", mas não o fez, transferindo para a instituição privada sem fins econômicos a responsabilidade pela assistência ao preso, incluindo a educação.

Nesse tema, a Resolução da SAP - 59, de 13/6/2003, trata dos dispostos na LEP apenas no que se refere às bibliotecas, "providas de livros instrutivos, recreativos e didáticos (art. 21), e prevê o ensino médio, quando a LEP é omissa sobre o tema. No entanto, isto não significa que a Resolução seja mais abrangente em termos de garantia dos direitos educativos, ao contrário, há um nítido rebaixamento em relação às determinações da Lei Federal.

O artigo 18 da LEP determina: "O ensino de primeiro grau será obrigatório, integrando-se no sistema escolar da unidade federativa", enquanto a Resolução estabelece: “Todos os presos analfabetos receberão curso de alfabetização e ensino fundamental com, no mínimo, três aulas semanais". A menção à integração ao sistema escolar foi suprimida e, no seu lugar, indica o que poderia ser uma carga horária mínima, mas que, com a redação formulada, sequer pode ser interpretada - o que significa "três aulas semanais"? Qual a 
duração? Se o ensino fundamental não está vinculado ao sistema escolar, quem se responsabiliza por ele?

A imprecisão da redação indica que a educação formal, nos CRs, deve seguir o padrão da precarização verificado no restante do sistema penitenciário paulista, já apontado anteriormente neste trabalho e em outros estudos.

A menção ao ensino médio, que poderia ser um avanço em relação à LEP, é pouco efetiva, dada a imprecisão dos termos "dentro das possibilidades frente ao item anterior", que é justamente aquele que prevê ensino fundamental sem estabelecer como deverá ser estruturado.

No item sobre formação profissional, novo rebaixamento da norma federal, que diz, em seu artigo 19, que "O ensino profissional será ministrado em nível de iniciação ou de aperfeiçoamento técnico", e, no Parágrafo único, estabelece que "A mulher condenada terá ensino profissional adequado à sua condição". A Resolução determina: "Os presos receberão formação profissional, em nível de iniciação, nos termos do artigo 19 da LEP, por meio do trabalho artesanal e industrial". A menção ao respeito às especificidades de gênero foi suprimida; a modalidade de ensino "ensino profissional”, prevista na LDB, foi substituída por “formação profissional", termo bastante impreciso e que não permite estabelecer qualquer parâmetro de aferição de qualidade ou pertinência dos cursos ofertados. Também, a LEP determina que o ensino profissional seja em nível formal ou de aperfeiçoamento técnico, e a Resolução admite apenas o nível de iniciação e por meio do trabalho artesanal e industrial, o que pode ser interpretado como braçal ou atividades menos qualificadas socialmente e no mercado de trabalho.

Nunca é demais lembrar Rusche e Kirchheimer (2004) quando dizem que, historicamente, as condições de vida na prisão são formuladas com o rebaixamento das condições mínimas ofertadas do lado de fora dos muros; e esta é a exata interpretação para a formulação da Resolução SAP no que se refere à educação. Pior ainda: trata-se de um documento que transfere as responsabilidades do Estado para uma entidade privada, e já o faz determinando que a assistência prestada seja precária, confirmando o princípio de lesser eligiblity (Wacquant, 2002, p.36). 


\subsubsection{A transferência de responsabilidade}

A Lei de Execução Penal (Lei Federal 7.210/84) determina no seu artigo 4․ " O Estado deverá recorrer à cooperação da comunidade nas atividades de execução da pena e da medida de segurança”.

No artigo 6, estabelece que são órgãos da execução penal: o Conselho Nacional de Política Criminal e Penitenciária; o Juízo da Execução; o Ministério Público; o Conselho Penitenciário; os Departamentos Penitenciários; o Patronato; e o Conselho da Comunidade.

$\mathrm{Na}$ determinação da composição desses órgãos, a presença de "representantes da comunidade" é prevista tanto no Conselho Nacional de Política Criminal e Penitenciária (CNPCP) quanto no Conselho Penitenciário, além de, obviamente, no próprio Conselho da Comunidade.

O CNPCP é subordinado ao Ministério da Justiça e tem entre suas atribuições a proposição de diretrizes para a política criminal e penitenciária, bem como estimular estudos e pesquisas no campo, além de ser responsável pela avaliação periódica do funcionamento do sistema prisional no País.

$\mathrm{Na}$ definição de sua composição, que é designada pelo Ministério da Justiça, há nítida intenção de que seus membros sejam especialistas da execução penal, preferencialmente da área do Direito, como demonstra a redação da Lei ao relacionar: "professores e profissionais da área do Direito Penal, Processual Penal, Penitenciário e ciências correlatas, representantes da comunidade e dos ministérios da área social”. Verifica-se que não há qualquer qualificação sobre quem poderiam ser tais representantes.

O CNPCP, que tem caráter disponível na página eletrônica do Ministério da Justiça, assinala que dos 13 membros, nove profissionais são da área do Direito, vinculados a órgãos do Sistema de Justiça e/ou instituições de ensino e pesquisa; há dois profisssionais de Psicologia, sendo um professor universitário, que já atuou no sistema prisional, e uma pesquisadora; há um médico psiquiatra, especialista em drogadição e, por último, um jornalista e pesquisador do campo dos Direitos Humanos, que também atua como consultor na área da segurança pública. Não há nenhum representante de organizações da sociedade civil e também estão ausentes os representantes de ministérios da área social.

O Conselho Penitenciário é estabelecido pela LEP (artigo 69) como órgão consultivo e fiscalizador da execução da pena. Seus membros são nomeados pelos governadores dos Estados, territórios e Distrito Federal, e sua composição é idêntica à do CNPCP, exceto por não haver menção a representantes dos órgãos gestores das áreas sociais: "professores e 
profissionais da área do Direito Penal, Processual Penal, Penitenciário e ciências correlatas, bem como por representantes da comunidade".

A composição do Conselho Penitenciário de São Paulo não está disponível na página eletrônica da SAP, embora exista naquele Portal Eletrônico menção a ele, e também em nenhum outro portal acessível pela internet. A informação foi obtida mediante contato com a assessoria da presidência do órgão, fato que contraria o objetivo, expresso na LEP, de que o órgão, assim como os demais conselhos, seja um canal de cooperação entre Estado e comunidade - como a comunidade pode participar se não tem acesso, sequer, ao nome de seus representantes?

Mas a composição deste Conselho responde à pergunta, ao indicar que intenção não é a participação da "comunidade" em geral, mas, sim, de órgãos e entidades que representam, ou são constituídos, estritamente por profissionais do Direito e profissionais do campo da saúde mental. As 30 vagas do Conselho são assim ocupadas: seis, para a Ordem dos Advogados do Brasil - Secção de São Paulo; seis, para o Ministério Público Estadual; três, para o Ministério Público Federal; três, para a Defensoria Pública; nove, para o Conselho Regional de Medicina - Psiquiatras; e três vagas para o Conselho Regional de Psicologia Psicólogos.

Essa composição indica prevalecer, entre os gestores públicos, a concepção de que a execução da pena deve ser baseada em dois pilares: leis e mecanismos de controle do comportamento. São esses profissionais os especialistas no tema prisão - ausentes estão profissionais de outros campos do conhecimento, assim como organizações da sociedade civil que não representem advogados ou profissionais da saúde mental.

Por fim, a LEP, em seu artigo 80, determina que haverá um Conselho da Comunidade em cada comarca, composto no mínimo, por um representante de associação comercial ou industrial, um advogado indicado pela Seção da Ordem dos Advogados do Brasil e um assistente social escolhido pela Delegacia Seccional do Conselho Nacional de Assistentes Sociais. Em parágrafo único, estabelece que: "na falta da representação prevista neste artigo, ficará a critério do juiz da execução a escolha dos integrantes do Conselho".

As atribuições do órgão estão estabelecidas no artigo 81 e são assim descritas:

I - visitar, pelo menos mensalmente, os estabelecimentos penais existentes na comarca; II - entrevistar presos; III - apresentar relatórios mensais ao juiz da execução e ao Conselho Penitenciário; IV - diligenciar a obtenção de recursos materiais e humanos para melhor assistência ao preso ou internado, em harmonia com a direção do estabelecimento. (LEP, art. 81). 
O caráter do Conselho da Comunidade não está definido no texto da LEP. A descrição de suas atribuições também é ambígua, dando margem a diferentes interpretações, pois abarca ações de monitoramento das condições das unidades prisionais - visitar unidades, ouvir presos e apresentar relatórios -, com responsabilidade sobre o financiamento das atividades relacionadas à execução da pena.

De acordo com o dicionário Houaiss, o termo "diligenciar" significa "1 atender, socorrer com diligência; 2 empregar, com presteza, os meios para; empenhar-se, esforçar-se, cuidar". A formulação deste artigo da LEP divide a responsabilidade sobre a garantia de recursos para a "assistência" entre representantes da sociedade civil no Conselho da Comunidade e as direções das unidades, contrariando a determinação do artigo 10 da mesma Lei, que estabelece o dever do Estado na garantia da "assistência ao preso", definida no artigo 11 como: "material, à saúde, jurídica, educacional, social e religiosa".

O artigo citado afirma que os recursos são para "a melhor" assistência, o que indica que tem caráter complementar em relação a outras fontes de recursos. No entanto, conforme indicam as entrevistas realizadas tanto com funcionários responsáveis pelas atividades de educação nas unidades pesquisadas quanto com o gestor responsável pelo setor de Ressocialização da SAP e a própria Funap, não há recursos destinados pelo Estado às atividades educativas, e a sua realização depende do empenho dos funcionários em buscar convênios com o governo federal, recursos privados ou do voluntariado.

Nessa conjuntura, as atribuições dos membros dos Conselhos da Comunidade indicam a expectativa de que, além das pessoas que representam o Estado, outras, algumas vezes representando instituições não governamentais, busquem recursos para a assistência à população penitenciária.

Essa configuração perpetua, na administração prisional do presente, o papel que a filantropia desempenha desde a criação da instituição prisão, conforme registrado por diferentes autores, entre eles Garland $(2008)^{124}$. Segundo este autor, no entanto, a partir dos anos noventa do século XIX, o Estado passa a assumir a responsabilidade pelo bem-estar dos presos, consequência do "otimismo liberal do século XX" (2008, p. 110).

A situação do Brasil, em relação à participação da filantropia na assistência à população carcerária, é bastante diversa. Salla (1997), ao refletir sobre as práticas de encarceramento desenvolvidas em São Paulo no período entre a emancipação política do País até a década de 1930, demonstra que a pena de prisão ganhou destaque no Brasil desde o

\footnotetext{
${ }^{124}$ Cf.: RUSCHE e KIRCHHEIMER, 2004; FOUCAULT, 1979.
} 
início do século XIX, impulsionada pelas ideias iluministas e em substituição das penas corporais.

No entanto, diferentemente dos Estados Unidos e da Europa onde "a pena de prisão passa a ser empregada simultaneamente à ampliação dos direitos do indivíduo como cidadão, esta mesma pena começou a ser utilizada no Brasil quando ainda conservava uma estrutura social cindida pelo escravismo e pelas diferenças e distâncias no acesso dos indivíduos à lei”, (SALLA, 1997, p.14)

Em razão dessa distinta conjuntura social, no que se refere aos direitos de cidadania e, consequentemente, nos deveres do Estado na garantia de direitos, a atuação das entidades filantrópicas, notadamente aquelas vinculadas à Igreja Católica, a assistência aos presos não foi substituída pelo poder público em São Paulo, até a década de 1980, quando a Congregação de Nossa Senhora da Caridade do Bom Pastor d'Angers deixou a administração da Penitenciária Feminina do Tremembé (SALLA, 1997, p. 111). Em 1977, a mesma Congregação deixara a direção da Penitenciária Feminina da Capital, onde atuou desde a sua criação, no início da década de 1940 (GRACIANO, 2005).

No século XIX, a filantropia era responsável por toda a assistência, e Salla (1997) cita diversos documentos que demonstram que, até a metade do século XIX, as pessoas presas na cadeia de São Paulo, instalada no andar inferior da Casa da Câmara, eram alimentadas pela Irmandade da Misericórdia e da Sociedade Filantrópica (SALLA, 1997, p. 32). Tendo a Lei imperial de 1928 previsto a criação de comissões, vinculadas às Câmaras Municipais, que deveriam visitar cadeias e elaborar relatórios sobre as condições verificadas, em 1833, a ausência do Estado na garantia da alimentação foi alvo de críticas da comissão de São Paulo:

apontava a Comissão para a precariedade desta solução e indicava que à Câmara caberia o ônus do sustento dos presos e não confiar tão importante questão a uma sociedade (Sociedade Filantrópica) que apesar dos 'grandes benefícios que ela tem feito nesta Cidade" poderia falir ou deixar de prestar serviço adequadamente. (SALLA, 1997, p. 34).

De acordo com Salla, a situação da alimentação era tão precária, desde o período da Colônia, que em 1848 um grupo de presos da Cadeia de São Paulo solicitou à Assembleia Legislativa Provincial autorização para pedir esmola com a colaboração do mordomo da Santa Casa de Misericórdia (1997, p. 40).

No mesmo sentido, e também atestando a origem histórica da inter-relação entre filantropia, religião e educação, ao analisar as práticas punitivas da sociedade escravista brasileira do século XIX, Koerner (2006) narra alguns aspectos do funcionamento da Casa de 
Correção, instalada em São Paulo e Rio de Janeiro em meados do século XIX. De acordo com o autor, em relação à "condição moral, religiosa e instrutiva dos presos", havia um capelão católico, que dizia missas e dava assistência a eles. O serviço de educação só fora implantado há pouco tempo pelo capelão, o qual ensinava 'rudimentos de gramática e aritmética' a cerca de um terço dos presos" ( 2006, p. 4).

Em relação às mulheres presas, Soares e Ilgenfritz (2002) contam que, na década de 1920, foi criado o Patronato das Presas, instituição benemérita destinada a auxiliar o Conselho Penitenciário, integrada por senhoras das famílias da elite brasileira, e pelas religiosas da Congregação do Bom Pastor. Em 1941, quando foi criada a primeira penitenciária feminina do País - Bangu -, as religiosas compartilharam sua gestão com o Estado, assim como o fizeram nas unidades femininas paulistas.

Em que pesem os avanços representados pela Lei de Execução Penal de 1984 no sentido de afirmar o dever do Estado e o direito da população carcerária no acesso à “assistência” (TEIXEIRA, 2006; SALLA, 2007), ao estabelecer a partilha entre sociedade civil e direções de unidades sobre a responsabilidade de buscar as condições materiais e humanas para garantir a assistência, vê-se o reforço de duas características que historicamente marcam o funcionamento das prisões no Brasil. A primeira, como demonstrado, está relacionada à omissão estatal na garantia de recursos, transferindo esta responsabilidade a agentes privados.

A segunda característica é destinar autonomia total às direções de unidades para a gestão dessas unidades, tanto assim que se pode afirmar também tratar-se de uma gestão, senão privada, porque desempenhada por um funcionário pertencente ao aparato burocrático do poder público, absolutamente pessoal.

Salla (1997, p. 80), ao analisar a administração da Casa de Correção de São Paulo, instalada em 1852, afirma: "centrava-se na figura do diretor o ruma de cada um dos aspectos da Casa de Correção. Entendia-se que a eficiência desta, em boa medida, dependia da vontade e das virtudes de seu administrador". E esta dimensão é reforçada pela LEP no que se refere à busca dos recursos para as unidades.

Com tamanha ambiguidade no texto da LEP quanto à atribuição dos Conselhos da Comunidade, e ainda com forte influência das condições históricas que marcaram o surgimento das prisões no País, o caráter desses órgãos varia de acordo com o posicionamento de seus membros, podendo assumir características de monitoramento, constituindo-se como órgão autônomo, ou de auxílio na execução da pena, subordinando sua atuação tanto às 
direções de unidade, às secretarias de administração penitenciária, e ao Poder Judiciário, e, por fim, reinventando a filantropia de tempos passados.

O Conselho da Comunidade da Comarca de São Paulo, instalado em 2005, por exemplo, em seu Regimento Interno (3/10/2007) não incorporou entre as atribuições de seus membros (artigo 19) o "diligenciamento" por recursos materiais, mas ressalta "a inspeção e fiscalização dos estabelecimentos penais" e "discutir propostas referentes à melhoria da assistência ao preso, ao internado e ao egresso".

Em agosto de 2009, os profissionais do direito eram a maioria, sendo 14 num total de 30 membros; quatro representantes de ONGs - três que atuam na defesa dos direitos civis e uma relacionada à educação -; dois representantes de diferentes igrejas; dois profissionais liberais; um pesquisador; um médico, vinculado à gestão pública municipal; um assistente social e um dentista, e os respectivos representantes da Fiesp, Senai e Fecomercio, além de um egresso do sistema prisional.

A presença de representantes do empresariado justifica-se pela expectativa que estes contribuam tanto com a disponibilização de postos de trabalho durante o período da prisão - o trabalho é uma das garantias da LEP - quanto na colocação profissional dos egressos do sistema prisional.

Ainda não foram produzidas análises sobre a efetividade da atuação desse conselho no campo do monitoramento. Alguns de seus conselheiros afirmam que as direções de unidades não respondem ou consideram suas recomendações nos relatórios de visitas, informação corroborada por Carreira (2009), que relaciona entre as dificuldades encontradas pelos Conselhos de Comunidade do Estado de São Paulo:

\footnotetext{
falta de retorno das reivindicações encaminhadas às autoridades em geral; ausência de liberdade de decidir sobre o local e horário das visitas de monitoramento às unidades prisionais, necessitando de agendamento prévio. Não há também liberdade de escolha do sentenciado a ser entrevistado e dificuldades diversas no contato com as direções das unidades. (CARREIRA, 2009, p. 52).
}

De acordo com o Plano Diretor do Sistema Penitenciário de São Paulo, em fevereiro de 2008, o Estado possuía 88 Conselhos da Comunidade, sendo que 22 não estavam atuando. O Ministério da Justiça considerou que estes resultados são "insuficientes", e que "não há por 
parte da SAP/SP ações de fomento que visem à criação ou implantação de novos Conselhos de Comunidade ${ }^{125}$.

Dessa forma, apesar dos inegáveis avanços formais nas possibilidades de participação da sociedade civil no ambiente prisional, não se tem verificado maior incidência de sua atuação. Ao contrário, como lembra $A$., demonstram as dificuldades em obter informações, o sistema está fechado, avesso mesmo à presença de pessoas de fora em seu cotidiano.

Nos espaços formalmente constituídos para a atuação da "comunidade", nota-se a presença majoritária de "especialistas" do campo do Direito. Embora as notícias sobre crime e castigo empolguem a população em geral, a aplicação e gestão das penas, em toda a sua complexidade, é um campo restrito, monopólio dos profissionais do Direito.

Christie (1998, p. 194), refletindo sobre a cultura do controle do crime, critica a especialização que domina o Judiciário na determinação das penas. Para o autor, a especialização profissional leva ao afastamento dos valores e regras produzidos culturalmente, que por sua vez expressam a partilha de uma experiência humana comum:

\begin{abstract}
Treinamento profissional significa longa especialização. Significa o aperfeiçoamento de certas habilidades, mas também de certos valores. Uma longa especialização significa também uma longa distância da essência básica da experiência humana. Na maior parte das vezes, a profissionalização significa a garantia de um bom emprego em determinada área, mas reduz as garantias de que seja dada atenção a uma totalidade de valores, ao senso comum popular.
\end{abstract}

O autor propõe que o ritual do julgamento e da atribuição das penas seja deslocado do campo do Direito para o da Cultura: "Somos livres para decidir qual o nível de punição que achamos aceitável. Não há regras, apenas valores” (Christie, 1998, p. 200).

Estendendo esta reflexão para os espaços de formulação, gestão e monitoramento das políticas prisionais, conclui-se que também estes estão submetidos à lógica da interpretação de leis, não havendo possibilidade de intervenção de outros campos do conhecimento. Não é de se estranhar, neste caso, a ausência de educadores ou de gestores das pastas da Educação, na definição dos membros dos conselhos previstos na LEP, mesmo sendo a prisão formalmente mantida para efeito de "reeducação" de pessoas.

\footnotetext{
${ }^{125}$ Relatório apresentado pela SAP/SP, como parte das determinações contidas no Pronasci. Disponível em: < http://portal.mj.gov.br/data/Pages/MJE7CD13B5ITEMID2AC5EC2AC7834C729B1465

BE75D88371PTBRIE.htm>. Acesso em: 12 fev. 2010.
} 


\subsection{A mobilização por educação}

\subsubsection{Presença antiga}

Em relação à educação, a participação da sociedade nas ações do Estado, sobretudo na alfabetização de jovens e adultos, não é um fenômeno recente no Brasil. Ao contrário, este grupo sempre foi chamado a concretizar as campanhas coordenadas pelo governo federal, desde a década de 1940. No entanto, a natureza dessa participação assumiu diferentes formas ao longo do período, variando de acordo com a conjuntura política e econômica.

Nas décadas de 1940 e 1960, a sociedade foi chamada a engajar-se nas campanhas organizadas pelo governo federal. Também como já descrito neste trabalho, o período imediatamente anterior ao golpe militar - 1959 e 1964 - foi marcado por diversas iniciativas na área da educação de jovens e adultos, que envolviam, novamente, governos estaduais e municipais e setores da sociedade civil.

De acordo com Haddad (2002, p. 39), nos anos de 1960 e 1970, já durante a ditadura militar, pessoas vinculadas aos setores das igrejas progressistas, partidos políticos e universidades, aglutinaram-se em pequenas organizações e nelas realizavam "processos educativos que eram absolutamente desligados dos processos educativos oficiais, ou seja, dos sistemas públicos de ensino."

No período pós-ditadura militar, esses grupos continuaram atuando por meio de práticas educativas destinadas a estimular a reflexão sobre a realidade. Persistia sua “intencionalidade política", mas agora, além da alfabetização baseada na reflexão da vida cotidiana dos educandos e voltada para a transformação dessa realidade - conforme as propostas pedagógicas de Paulo Freire -, incorporaram como missão "a reconstrução do tecido social que havia se rompido com a ditadura, a defesa dos direitos humanos e a educação popular”. Sua atuação não pode ser definida como clandestina, mas, em virtude da repressão política do período, não tinha “visibilidade pública” (HADDAD, 2002, p. 39).

Na década de 1980, simultaneamente ao processo de redemocratização do País, os grupos que atuavam na área da educação ampliaram sua atuação, em função de novas demandas sociais e, com elas, o surgimento de novos atores, como relata Haddad (2002, p. 40): 
Eram os movimentos de bairros, as associações de moradores e organizações populares; os movimentos sindicais autênticos que se constituíam à margem do movimento sindical oficial; os movimentos de mulheres e o movimento negro; os movimentos autônomos de luta por moradia, terra e trabalho. (HADDAD, 2002, p. 40).

De acordo com o autor, essas novas organizações traziam consigo a demanda por formação - não a formal ou oficial, mas aquela voltada para a reflexão sobre sua realidade e as possibilidades de transformação. Nesse sentido, as populações empobrecidas, que não tiveram acesso à escolaridade durante a infância, deixaram de ser o público exclusivo das organizações que exercitavam a educação popular.

Ainda na década de 1980, a educação deixou de ser apenas meio de atuação para as organizações para tornar-se também objeto de reivindicação. A universalização do acesso ao ensino público de qualidade foi um importante foco de mobilização social, que pode ser constatado nas polêmicas e embates travados durante o processo da Assembleia Nacional Constituinte, em 1987 e 1988. "A proposta da Constituinte mobilizou a sociedade brasileira. A educação foi um dos temas mais discutidos e em torno do qual diversas atividades foram realizadas para definir os princípios da nova Carta"(PINHEIRO, 1996, p. 259).

Assim como se deu com a mobilização pela garantia dos direitos humanos das pessoas presas, no campo educacional, o período de abertura democrática também dividiu setores da sociedade que atuavam conjuntamente até aquele momento. Conforme demonstra Pinheiro (1996), a mobilização ocorrida durante o processo Constituinte explicitou as divergências e cunhou campos distintos, com demandas concorrentes entre si.

Na opinião de Pinheiro (1996, p. 260-66), a polêmica deu-se em torno da disputa pelo significado do conceito de "público", em relação à educação. Três foram as conceituações utilizadas: "o público mantido pelo Estado; o público não Estatal; e o público como serviço público". Em torno de cada um desses conceitos reuniram-se diferentes organizações da sociedade civil, orientadas por interesses diversos, relativos à sua missão institucional, orientação religiosa ou posição econômica. Mais que uma questão conceitual, estava em disputa o destino dos recursos do Estado para o financiamento da educação.

A escola pública mantida pelo Estado foi defendida pelo Fórum da Educação As escolas confessionais e comunitárias defendiam o conceito de público não Estatal, sob o argumento de que, diferentemente das escolas privadas, não possuíam fins lucrativos. Por último, o conceito de público como "serviço público" foi defendido pela Federação Nacional dos Estabelecimentos de Ensino (Fenem). Este conceito nega a distinção entre escola privada 
e pública, por admitir que toda educação, ministrada ou não pelo Estado, é um serviço público.

De certa forma, esse debate é recolocado na cena pública em relação à educação nas prisões, e permeia a relação entre a educação formal e a não formal naquele ambiente, sobretudo no que se refere às fontes de financiamento e ao papel das organizações da sociedade civil.

A partir da década de 1990, assegurados os direitos educativos do ponto de vista formal por meio da Constituição Federal e, depois, da Lei de Diretrizes e Bases da Educação (1996) e do Plano Nacional de Educação (2001), as organizações passaram a atuar de diferentes maneiras no campo educacional. De um lado, por meio de ações de mobilização para pressionar governos a cumprirem as garantias estabelecidas nas normas. Neste novo contexto, diferentes grupos estabeleceram articulações para elaborar demandas públicas à universalização do acesso, disputar o sentido do termo qualidade da educação, exigir ampliação do financiamento público e ocupar os espaços de controle social sobre as políticas educacionais $^{126}$.

De outro lado, há organizações que atuam na proposição e na execução de projetos de cunho pedagógico, que podem ser desenvolvidos no âmbito da educação formal, e também aquelas que ofertam atividades de educação não formal, algumas vezes realizadas no próprio ambiente escolar, outras, em espaços diversos.

\subsubsection{Demanda recente}

Em relação às prisões, os dados levantados nesta pesquisa permitem afirmar que a sociedade civil está presente na educação em prisões mais intensamente na segunda forma de atuação: ofertando e promovendo atividades de educação não formal.

Poucas, e recentes, foram as referências de ações de mobilização em defesa dos direitos educativos das pessoas encarceradas identificadas. Até meados da primeira década do Novo Milênio, não havia registros de ações de mobilização de organizações da sociedade civil para assegurar os direitos educativos de pessoas adultas privadas de liberdade. A partir de 2006, conforme pôde-se observar na análise da cobertura da mídia sobre o tema, apresentada no Capítulo 2, e também ao longo da pesquisa de campo desenvolvida no âmbito deste

\footnotetext{
${ }^{126}$ Cf.: $<$ http://www.campanhaeducacao.org.br>; $<$ http://:www.todospelaeducacao.org.br $>$.
} 
trabalho, há algumas referências à demandas da sociedade civil no campo, que serão relacionadas a seguir.

Destaca-se a atuação da Relatoria Nacional pelo Direito Humano à Educação, que desde 2005 vem realizando visitas a instituições prisionais de diferentes Estados para verificar as condições de ensino e aprendizagem. O processo de organização das visitas das relatoras ${ }^{127}$ envolveu organizações locais de direitos humanos e, também, vinculadas ao campo da educação. Em geral, são organizações que atuam e participam de redes temáticas de organizações que se unem tanto para auxiliar a Relatoria no agendamento das visitas quanto para preparar audiências públicas, que reúnam gestores responsáveis pelas áreas da educação e da administração da prisão, parlamentares, sistema de Justiça e mídia.

As visitas realizadas geram relatórios com recomendações dirigidas aos diferentes atores responsáveis pela garantia da educação no ambiente prisional. Um primeiro relatório foi produzido em 2006, exclusivamente sobre a situação de algumas unidades prisionais de Pernambuco. Em novembro de 2009, foi lançado o relatório produzido com base nas visitas às unidades prisionais de São Paulo, Rio Grande do Sul, Distrito Federal, Pernambuco e Pará.

As iniciativas são bastante recentes e não há elementos para afirmar sobre sua efetividade da perspectiva da superação das violações aos direitos de ensino e aprendizagem, apontadas nos relatórios. No entanto, é preciso registrar que o processo de organização das missões criou uma situação inusitada, ao provocar organizações da sociedade civil a se debruçarem sobre um tema pouco ou nada visível, da perspectiva do Direito.

Em abril de 2006, organizações de São Paulo organizaram um abaixo-assinado, encaminhado ao Congresso Nacional, reivindicando a alteração da Lei de Execução Penal a fim de que estabeleça a remição penal pelos estudos. Esta já era uma demanda colocada por organizações do campo do Direito, baseada inclusive no fato de que alguns juízes já concediam a remição sob a alegação de tratar-se de trabalho intelectual.

A novidade da ação foi a busca de articulação com organizações do campo da educação e que o movimento adquiriu caráter nacional, com a adesão de entidades de diferentes Estados ${ }^{128}$.

A matéria segue tramitando no Congresso Nacional, onde há 14 projetos sobre o tema (seis, na Câmara e sete, no Senado) ${ }^{129}$, o que poderia indicar o fracasso da articulação. No entanto, os desdobramentos apontam outras possibilidades de análise.

\footnotetext{
${ }^{127}$ No período, exerceram o mandato de relatoras a educadora Edla Soares e a jornalista Denise Carreira.

${ }^{128}$ Cf. AÇÃO EDUCATIVA. Movimento pede aprovação da remição da pena de prisão pela educação.

Disponível em: <http://www.acaoeducativa.org.br/portal/index.php?option=com_content\&task= view\&id=435\&Itemid=149>. Acesso em: 12 nov. 2009.
} 
Desde essa primeira iniciativa coletiva, algumas das organizações que participaram vêm desenvolvendo outras estratégias a fim inserir o tema na agenda do debate público sobre educação.

Entre as ações, destaca-se a mobilização em torno da aprovação das Diretrizes Nacionais para a Educação nas Prisões, por meio de envio de cartas aos Ministérios da Educação e Justiça em 2007 e a introdução deste tema nas conferências livres, organizadas durante o processo preparatório da Conferência Nacional de Segurança Públicas ${ }^{130}$.

Em janeiro de 2009, o mesmo grupo organizou seminário e oficina de trabalho no Fórum Social Mundial, realizado em Belém. Foi a primeira vez que o evento, organizado desde 2001, registrou a realização de uma atividade sobre o tema. Participaram mais de 150 pessoas de diferentes países, e a oficina de trabalho elegeu o que considerou ser a "agenda da sociedade civil”, que incluía, além da aprovação das Diretrizes Nacionais para a Educação nas Prisões, a participação articulada no processo de preparação da Confintea VI, a mobilização pela remição pelo estudo e a reflexão coletiva sobre a condição de trabalho dos profissionais da educação no ambiente prisional.

Ao longo do ano, não houve registro sobre atividades ou mobilizações realizadas em cada um dos grupos, exceto àquele referente à aprovação das Diretrizes, que envolveu as estratégias descritas anteriormente.

Durante o período de desenvolvimento desta pesquisa, também foi identificada a criação da Associação dos Educadores em Espaços de Privação da Liberdade do Rio de Janeiro (Aeplierj), cujo Estatuto data de janeiro de 2008. Os objetivos da instituição, anunciados nesse documento, são bastante amplos, contemplando ações que são de atribuição do Estado, das universidades e também do campo da educação não formal ${ }^{131}$.

${ }^{129}$ STRATEGOS, Empresa Jr de Consultoria Política. Agenda Legislativa. Remição da pena pelo estudo. Junho/2008, mimeo

${ }^{130}$ Cf.: Observatório da Educação. Atividades no FSM 2009 resultam na criação de grupo de trabalho sobre educação nas prisões. Disponível em: <http://www.observatoriodaeducacao.org.br/index.php? option=com _ content\&view=article\&id=621:atividades-no-fsm-2009-resultam-na-criacao-de-grupo-de-trabalho-sobreeducacao-nas-prisoes\&catid=64:eja-e-educacao-nas-prisoes\&Itemid=102>. Acesso em: 23 nov. 2009.

AÇÃO EDUCATIVA. Preparação para a Conseg aponta para participação social e garantia de direitos. 30/7/2009. Disponível em: http://www.acaoeducativa.org.br/portal/index.php?option= com_content \&task $=$ view\&id=1875\&Itemid=149. Acesso em: 23 nov. 2009.

${ }^{131}$ Art. $2^{\circ}$ - A entidade inspira-se nos princípios da legalidade, impessoalidade, moralidade, publicidade, economicidade, eficiência, igualdade, liberdade e nos ideais de solidariedade humana; não visa lucros; tem caráter educacional, filantrópico, informativo, cultural, beneficente, de assessoria e assistência social, tendo por objetivos: I) Representar a categoria perante o poder público e a sociedade civil organizada em reuniões, fóruns, seminários, congressos, debates; II) Democratizar a informação, principalmente àquela relevante aos espaços de privação de liberdade e de medidas sócio-educativas; III) Acompanhar e fiscalizar quaisquer projetos que interfiram no espaço prisional sejam eles demandados pelo poder público ou a partir de associações privadas, notadamente ONGs; IV) Oferecer e organizar cursos de formação inicial e continuada para todos os profissionais que atuam nos sistemas privadores de liberdade, e proporcionar a produção e acesso a material educacional 
Além de extrapolar as demandas trabalhistas, é interessante o fato de a Aeplierj colocar entre seus objetivos: "Acompanhar e fiscalizar quaisquer projetos que interfiram no espaço prisional sejam eles demandados pelo poder público ou a partir de associações privadas, notadamente ONGs". Durante o seminário realizado no Fórum Social Mundial, em janeiro de 2009, o presidente da Aeplierj criticou a atuação das ONGs no ambiente prisional, alegando que os governantes deixam de investir na educação formal para financiar projetos de arte-educação, realizados por estas organizações. Trouxe para reflexão a polêmica em torno dos recursos públicos, como fonte de financiamento exclusivamente da educação pública, promovida por agentes governamentais.

As organizações não governamentais que atuam em sistemas prisionais e, da mesma forma, alguns professores de redes públicas que também atuam em prisões presentes no debate defenderam o trabalho de educação não formal realizado pela sociedade civil. No entanto, houve consenso sobre a necessidade de assegurar, por meio de medidas normativas, que a educação formal seja garantida em todos os estabelecimentos prisionais, conforme a legislação educacional vigente no País.

Quanto à transferência de recursos públicos, muitas das organizações presentes afirmaram ser legítimo que organizações da sociedade civil sejam financiadas com recursos de governos, desde que não retirados das verbas da educação formal e adotados procedimentos de transparência no acesso e prestação de contas. Os argumentos favoráveis ao financiamento público do trabalho da educação não formal realizado por organizações da sociedade civil baseavam-se na premissa de que se trataria de uma oferta pública, não estatal.

Antes de prosseguir com a temática do financiamento da educação não formal, e mesmo sem condições de refletir sobre os resultados concretos dos debates e mobilizações, por se tratar de fatos muitíssimo recentes, é preciso registrar que também no meio acadêmico o tema da educação em prisões ganhou destaque, com a criação, em 2008, de um Grupo de Trabalho específico no âmbito da Associação Nacional de Pesquisa em Educação (Anped).

pertinente, respeitando-se a autonomia do professor em sala de aula; V) Viabilizar a assistência jurídica, médica, funeral e outros benefícios aos associados; VI) Garantir a elaboração e a implementação de ações educativas, matriz curricular e avaliação apropriada às características e necessidades dos alunos em unidades educacionais destinadas a privados de liberdade; VII) Garantir a escolarização por meio de projetos que garantam uma organização curricular diferenciada, atendendo inclusive o caráter transitório do aluno; VIII) Garantir espaços adequados para o trabalho dos profissionais responsáveis pelos processos educacionais, incluindo: iluminação, ventilação, instalações sanitárias para alunos e corpo docente, espaços para atividades artísticas e serviço de merenda escolar, salas de aula, salas de vídeo e de reunião para o corpo docente e pais/responsáveis, salas de arquivo, copa e despensa; IX) Produzir, estimular, assessorar, promover e divulgar experiências que possam se constituir como Políticas Públicas, se comprometendo a não se colocar em substituição ao Estado e buscando fortalecer a coletividade; X) Trabalhar pela memória do patrimônio cultural material e imaterial dos grupos e atores sociais dos sistemas privadores da liberdade. (Estatuto da Aeplierj; jan/2008). 
É verdade que a maioria dessas iniciativas teve lugar depois da ação do governo federal, por meio do MEC e do Ministério da Justiça, no contexto do projeto "Educando para a Liberdade", já descrito anteriormente. No entanto, nenhuma das ações descritas tem por finalidade a busca de parcerias com governos; ao contrário, todas buscam a afirmação dos direitos educativos das pessoas adultas presas e reclamam pela atuação no Estado na sua garantia.

Além desse caráter de pressão, as iniciativas também podem ser interpretadas como formas de dar visibilidade ao assunto, estimulando diferentes segmentos a refletirem sobre o tema. Muñoz (2009) afirma que opinião pública é um dos principais obstáculos à garantia da educação nas prisões. Garland (2008) demonstra como a opinião pública, informada pelos meios de comunicação, contribui para que políticos - seja em cargos executivos ou legislativos, considerados de direita ou de esquerda (GARLAND, 2008; CHRISTIE, 1998; TEIXEIRA, 2006) - apoiem e proponham medidas para o endurecimento das penas e restrições dos direitos das pessoas encarceradas, preocupados em manter sua popularidade.

Nesse contexto, ganham especial relevância esses pequenos sinais de mobilização em torno da busca de compreensão sobre a educação em prisões, assim como de sua garantia. Pequeníssimos sinais, que se anunciam em meio a um contexto adverso, descrito neste mesmo capítulo, e constituído pelo contexto de fechamento das prisões à comunidade; a falta de informações para o exercício do controle social; os limites de atuação verificados nos espaços de participação social; e a desobrigação estatal em relação à garantia das assistências às pessoas presas.

\subsubsection{Quem paga a conta}

Ao analisar a insuficiência do orçamento público para cobrir os custos do encarceramento em massa promovido pelos EUA a partir da segunda metade da década de 1970, mesmo com a transferência de recursos das áreas sociais para a segurança pública, Wacquant (2002) descreve duas das principais estratégias adotadas por alguns governos de Estados americanos para a redução dos custos.

A primeira delas é a privatização de penitenciárias; a outra é a transferência dos gastos para a própria população carcerária. Neste caso, à pergunta “quem paga a conta?", a resposta seria: “o próprio preso", situação que, de acordo com Wacquant (2002, p. 21), tem provocado a ameaça de rebeliões e greves por parte de alguns prisioneiros, que alegam, nem eles, nem 
suas famílias, condições de arcar com encargos de sua manutenção pessoal. "Não se pode tirar água da pedra [...] Os contribuintes querem o castigo e as penas de prisão mas não querem pagar a conta. Talvez devessem pensar em penas alternativas”.

Embora tenha ampliado assustadoramente o encarceramento de seres humanos, demonstrado no Capítulo 1, o Brasil, de maneira geral, e o Estado de São Paulo, em particular, ainda não adotaram a privatização do sistema penitenciário, embora a experiência dos CRs possa ser considerada uma alternativa similar, motivada pela necessidade de redução de gastos (TEIXEIRA, 2006), e o debate sobre o tema esteja em curso, fortemente estimulado pela Fiesp, com o apoio de setores do governo ${ }^{132}$.

Da mesma maneira, pelo menos formalmente, o Estado garante um mínimo de condições materiais para a sobrevivência no interior das prisões, embora seja recorrente a reclamação da insuficiência dessa assistência, sobretudo no que se refere aos produtos de higiene pessoal ${ }^{133}$.

No campo da educação, no entanto, as pessoas presas no Estado de São Paulo, de certa forma, pagam por sua educação, ofertada pela Funap. Ao optar por não incluir a educação das prisões no sistema público de ensino, o Estado abdica de acessar os recursos do Fundo de Desenvolvimento da Educação Básica (Fundeb). O orçamento da Funap, por sua vez é constituído por recursos do Tesouro do Estado e recursos próprios, advindos da venda de produtos e serviços produzidos pelas pessoas presas. Desse orçamento, não há informação sobre a porcentagem destinada aos gastos com educação, trabalho ou assessoria jurídica.

Ainda assim, conforme a tabela abaixo, embora se verifique o aumento no valor do repasse de recursos do Tesouro do Estado, a comercialização do trabalho carcerário ainda é a principal fonte de financiamento da instituição.

\footnotetext{
${ }^{132}$ Seminário Internacional - Parceria Público-Privada no sistema prisional, organizado pela Fiesp e realizado em 18/3/2009, Artigos e exposições do evento. Disponível em: http://www.fiesp.com.br/ppp/interfaces/programas.asp. Acesso: 15 jan. 2010

${ }^{133}$ CEJIL e Outros, 2007.
} 
Tabela 23 - Orçamento Anual da Funap

\begin{tabular}{|c|l|l|l|l|}
\hline Fonte & \multicolumn{1}{|c|}{$\begin{array}{c}\text { Tesouro do Estado } \\
\text { Ano }\end{array}$} & \multicolumn{1}{|c|}{$\begin{array}{c}\text { Recursos Próprios } \\
\text { (R\$) }\end{array}$} & $\begin{array}{c}\text { Recursos Vinculados } \\
\text { Federais (R\$) }\end{array}$ & Total (R\$) \\
\hline 1999 & $15.145 .578,00$ & $11.212 .500,00$ & - & $26.358 .078,00$ \\
\hline 2000 & $15.237 .457,00$ & $11.629 .060,00$ & - & $26.866 .517,00$ \\
\hline 2001 & $13.334 .694,00$ & $13.616 .570,00$ & - & $26.951 .264,00$ \\
\hline 2002 & $11.426 .360,00$ & $16.669 .700,00$ & 10,00 & $28.096 .070,00$ \\
\hline 2003 & $11.812 .399,00$ & $32.663 .500,00$ & $803.400,00$ & $45.279 .299,00$ \\
\hline 2004 & $12.254 .731,00$ & $28.792 .380,00$ & $669.262,00$ & $41.716 .373,00$ \\
\hline 2005 & $13.821 .341,00$ & $20.820 .080,00$ & 20,00 & 34.641 .441 \\
\hline 2006 & $27.154 .488,00$ & $18.182 .200,00$ & 20,00 & 45.336 .708 \\
\hline 2007 & $19.674 .398,00$ & $21.595 .000,00$ & 20,00 & 41.269 .418 \\
\hline 2008 & $19.973 .873,00$ & $22.100 .000,00$ & - & 42.073 .873 \\
\hline 2009 & $21.166 .993,00$ & $27.550 .000,00$ & 40,00 & $48.717 .033,00$ \\
\hline
\end{tabular}

Fonte: Secretaria de Planejamento $-<$ http://www.planejamento.sp.gov.br/planorca/orca.aspx\#>.

Se a vinculação ao sistema público de ensino resolve o financiamento da educação formal, o mesmo não ocorre com a educação não formal. Conforme demonstrado ao longo deste trabalho, não há qualquer fonte regular de financiamento público às práticas não formais de educação.

Algumas delas terminam por serem viabilizadas pelos recursos públicos, mas de forma indireta e descontínua, como os convênios com o Ministério da Saúde. Outras são absolutamente voluntárias ou financiadas pela filantropia, sobretudo das igrejas. A Petrobrás financia o ITTC, mas não tem uma linha específica para projetos desenvolvidos em prisões, e o Quem Somos Nós é a única iniciativa do tipo financiada. Por fim, o único projeto que, aparentemente, tinha uma fonte regular de financiamento - o Leitura Ativa -, por meio de uma instituição de ensino superior privada, foi encerrado.

Se o Estado não financiar a educação não formal nas prisões - e, a julgar pelos depoimentos dos gestores da SAP e da Funap, pelo menos em São Paulo esta possibilidade não existe, ao contrário, o Estado espera que as ONGs e a iniciativa privada aloquem recursos para o seu trabalho -, quem financiará?

Ryynänen (2009), ao analisar o trabalho de educação não formal no campo da arteeducação, desenvolvido por uma $\mathrm{ONG}$ da Bahia, adverte que o financiamento tem se configurado como umas das dimensões mais complexas e multidimensionais do trabalho das ONGs.

De acordo com a autora, a busca por financiamento enfrentada por estas instituições tem alterado seu modo de atuação, levando-as a aproximar-se do mundo do marketing, na tentativa de vender sua imagem para possíveis financiadores. "Esta questão da imagem é, fundamentalmente, uma questão de poder e assim precisa ser analisada: são as elites quem 
definem a imagem desejada, e são as elites que controlam os recursos financeiros e os meios de comunicação" (RYYNÄNEN, 2009, p. 76).

Exemplificando suas considerações, Ryynänen relata as ponderações de um representante de uma organização "com forte identificação afrobrasileira", que alegava ter dificuldade em buscar financiamento no setor privado em razão do receio deste em "ficar identificado com este público específico" (2009, p. 76).

Se o setor privado de Salvador, onde cerca de $80 \%$ da população é afrodescendente, tem receio de ser identificado com este "público específico", é difícil imaginar que tipo de instituição privada gostaria de ser vinculada ao sistema prisional. Esta situação explica a estratégia do CDI, relatada por um de seus membros em entrevista, de não elaborar projetos específicos de inclusão digital no ambiente prisional, mas inserir esta ação em meio a projetos destinados a outros segmentos.

Sem recursos públicos e na impossibilidade de acessar as fontes privadas, as práticas de educação não formal, incluindo os cursos profissionalizantes, são marcadas pela precariedade e pelo improviso, perpetuando o que Salla (1997, p. 80) identificou haver ocorrido já em 1866, em um relatório sobre as condições de funcionamento da Casa de Correção de São Paulo: “o diretor afirmava que das oficinas existentes na Casa de Correção funileiros, ferreiros, sapateiros, alfaiates, chapeleiros, encadernadores e marceneiros - -, apenas a de encadernação era dirigida por um mestre como o qual se fizera um contrato, 'todas as outras eram conduzidas por presos e guardas'."

\subsection{Algumas conclusões}

\subsubsection{Sociedade civil e esfera pública}

O espaço prisional abriga práticas educativas não formais, desenvolvidas por organizações da sociedade civil com diferentes perfis. Ao lado da histórica atuação de voluntários vinculados às igrejas, verifica-se a presença de pessoas voluntárias ligadas às universidades e também de organizações da sociedade civil, constituídas em diferentes momentos do processo de construção da esfera pública. 


\subsubsection{Contestar a prisão}

O período de redemocratização política foi marcado pelo estímulo formal à participação da sociedade civil na definição e monitoramento das políticas públicas, mas, ao mesmo tempo, registrou a retomada do processo de construção de insensibilidade social em relação às prisões e, para tanto, um dos expedientes utilizados foi a desqualificação pública da ação das organizações identificadas com a defesa dos direitos humanos.

\subsubsection{Múltiplas expectativas}

As normas que orientam a participação da sociedade civil no ambiente prisional são ambíguas em relação à definição de papéis em relação ao Estado. Tal ambiguidade tem resultado em ações governamentais de transferência de responsabilidades a organizações privadas, sobretudo no que se refere na garantia da "assistência" ao preso.

As possíveis ações de monitoramento do funcionamento das instituições prisionais são ainda frágeis, e pouco representativas, uma vez que os espaços de interlocução são dominados por profissionais e gestores do campo jurídico e pelo estímulo à presença de setores vinculados ao empresariado.

\subsubsection{A mobilização por educação}

No campo educacional, embora a participação da sociedade civil - tanto em ações de exigibilidade, quanto na execução de projetos - seja bastante consolidada, tendo tido forte presença inclusive no processo de redemocratização do País, a educação em prisões nunca foi um foco de mobilização.

Há registros recentes de ações e atividades empreendidas por organizações na da garantia dos direitos educativos das pessoas adultas privadas de liberdade, mas são fatos tão recentes que se torna impossível analisar sua efetividade ou possíveis desdobramentos.

O que se nota é que a articulação entre organizações do campo da educação com aquelas do campo dos direitos humanos tem produzido uma nova demanda: que o Estado assuma a responsabilidade pela oferta e pela regulação da educação nas prisões. 


\subsubsection{A participação da sociedade civil}

As organizações da sociedade civil participam de duas diferentes formas na concretização da educação nos espaços de privação de liberdade. A primeira delas é a transferência da responsabilidade do Estado na oferta da educação para essas organizações. Este risco é potencializado pela ausência de definição sobre o que é educação nas prisões, sem a necessária distinção entre as práticas formais, não formais e informais, além das atividades de trabalho. Dessa forma, verifica-se que as práticas formais são substituídas pelas não formais, em suas variadas expressões. No entanto, é preciso considerar que a educação, quando destinada à formação integral dos indivíduos, extrapola o ensino escolar, responsabilidade do Estado. As práticas de profissionalização, arte-educação, formação para e em direitos humanos, e tantos outros temas, podem e devem ser compartilhadas entre Estado e sociedade civil.

Daí, o desafio colocado é, de um lado, obrigar o Estado a assumir a oferta da educação formal nas prisões e, de outro, criar condições para que as organizações da sociedade civil possam atuar como promotoras de atividades educativas. E as condições envolvem: de um lado, a necessidade de se definir um projeto de reabilitação para as pessoas presas, atribuição dos conselhos prevista na LEP, com a participação da comunidade, assim como diferentes setores da administração pública. Só essa definição pode superar o caráter pontual, fragmentário e desconexo das atividades realizadas nas prisões.

De outro lado, é preciso enfrentar o delicado tema da transferência de recursos públicos para a iniciativa privada. Como demonstrado neste trabalho, algumas das experiências foram desenvolvidas com recursos públicos, advindos de diferentes fontes de distintas esferas de governo. Essa prática tanto fragiliza as ações por sua descontinuidade, uma vez que são mantidas com recursos pontuais, e nenhuma esfera de governo mantém política de financiamento específica para tal fim, como impede o exercício do monitoramento sobre a sua execução. É preciso que sejam estabelecidos critérios públicos e transparentes para a celebração de convênios e parcerias, bem como mecanismos de acompanhamento de sua realização. Aliás, esta observação é válida para toda transferência de recursos públicos para a iniciativa privada, relacionada ao sistema prisional.

A segunda forma de atuação da sociedade civil sobre o tema da educação nas prisões é a mobilização por sua efetivação, que, como demonstrado anteriormente, é extremamente recente. 
Também, é preciso destacar que a presença da sociedade civil no ambiente prisional é fundamental para o exercício do controle social sobre a ação do Estado. Promovendo atividades educativas, ou não, as organizações têm a responsabilidade de tornar pública a realidade construída no interior dos muros e celas, buscando contribuir para o respeito aos direitos humanos.

Neste contexto de exercício da cidadania por meio da aproximação do ambiente prisional, alguns desafios se impõem. O primeiro deles é a necessária construção de um sistema público de informações sobre o sistema prisional, em geral, e da educação nas prisões, em particular. Sem dados abrangentes e confiáveis, é impossível tanto a formulação de políticas públicas quanto o monitoramento das ações do Estado. Há também que se estabelecer mecanismos institucionais para a denúncia de violações de direitos identificadas por educadores, sejam vinculados, ou não, a organizações da sociedade civil.

No entanto, todos esses aspectos só podem ser considerados se, simultaneamente a eles, for desenvolvido um intenso processo de sensibilização da sociedade em geral sobre os direitos educativos das pessoas encarceradas, e a necessária ação do Estado para garanti-lo. O desafio posto é a produção da sensibilidade, em oposição à produção da insensibilidade apontada em diferentes momentos deste trabalho. 


\title{
CONCLUSÕES
}

\section{EDUCAÇÃO NAS PRISÕES: SINAIS DE MUDANÇA}

\begin{abstract}
Pode-se então subverter a argumentação e colocar a hipótese de que a prisão está em mutação perpétua, que ela se adapta constantemente a seu tempo e que é preferível de compreendêla na sua contemporaneidade do que em seu aparente ahistoricismo. (CHANTRAINE; MARY, 2006) ${ }^{134}$.
\end{abstract}

Em uma de suas músicas, Raul Seixas diz: "Mas é que tudo acaba onde começou”. Chegar ao momento de redigir as conclusões de uma pesquisa não significa que ela tenha terminado ou tenha se esgotado, ou que todos os aspectos trazidos pela realidade tenham sido passíveis de análise com base nas teorias e reflexões já propostas por outras pessoas.

Chegar ao momento de redigir as conclusões, neste caso, significa apenas que é momento de, percorridos os caminhos propostos para a investigação e análise, sistematizar reflexões que dialogam com as hipóteses formuladas em 2005, quando tudo começou. O termo é mesmo dialogar, pois não há respostas e, em alguns casos, o resultado encontrado foi o da possibilidade de formulação de novas perguntas.

Em todo caso, seguindo a orientação do cantor, é preciso retornar ao início. E o início foi a constatação, feita em 2004, na Penitenciária Feminina da Capital, que, concomitantemente às aulas organizadas pela Funap de preparação para os exames de certificação, a escola na prisão possuía um calendário repleto de atividades, denominadas educativas e realizadas por diferentes atores: pessoas presas e voluntários de diferentes grupos. Na época, também se constatou que algumas das mulheres presas tinham participado do curso de formação "Promotoras Legais Populares" e que a experiência, por uma razão ou outra, tinha marcado suas vidas, ou melhor, sua forma de pensar a vida e interpretar a realidade vivida na prisão.

Comparando estes dois momentos - 2004 e 2008 - duas constatações se impõem. A primeira, está relacionada ao acesso às penitenciárias para efetuar as pesquisas. Em 2004, apenas a PFC foi tomada como campo para a pesquisa empírica; em 2008, além dela, foi incluída a Parada Neto. Em 2004, a orientação certeira - encaminhar à direção da unidade um ofício explicando os objetivos da pesquisa - foi suficiente para que a autorização fosse

\footnotetext{
${ }^{134}$ Tradução livre do original: "On peut alors renverser l'argumentation et faire l'hypothèse que la prison est en perpétuelle mutation, qu'elle s'adapte constamment à son temps et qu'il est préférable de la saisir dans sa contemporanéité plutôt que dans son a-historicisme apparent". (CHANTRAINE; MARY, 2006).
} 
concedida. Não apenas a autorização, mas também houve a possibilidade de uma longa entrevista com a diretora. Não foram estabelecidos prazos de permanência nem dias fixos ou horários - a escola da prisão estava aberta, foi possível acompanhar as aulas, entrevistar alunas e educadoras em ambientes fechados, restritos, sem ninguém por testemunha.

Em 2008, foram meses para descobrir o caminho, a quem pedir autorização. Ofícios foram enviados a diferentes órgãos, telefonemas e pedidos de esclarecimento foram dados até se chegar à conclusão que autorização deveria sair do gabinete do secretário de Administração Penitenciária - e assim foi feito.

E, aqui, um primeiro sinal, informação para a pesquisa, de que a prisão de 2008 não era a mesma de 2004. Tanto que a autorização para entrar nas unidades e entrevistar funcionários e pessoas presas deixou de ser atribuição das direções das unidades e se deslocou para o próprio secretário da Pasta.

Esta realidade é incoerente, parece não combinar com a tão propalada autonomia das direções, que marca a história das prisões no Brasil, como já apontado por diversos autores. $\mathrm{O}$ primeiro sinal: o acesso estava mais controlado, o que foi confirmado nas visitas. Porém, mesmo com a autorização do secretário, foram longos períodos de espera para entrar, desencontros de horários com funcionários, horários rígidos de permanência e a impossibilidade de entrevistas com as pessoas presas em espaços reservados, o que resultou em falas também controladas. Tudo mais difícil, mais fechado, pelo menos para a pesquisa.

Ao lado da constatação da ampliação do controle sobre o acesso às unidades, outro indício de mudança: poucas são as atividades realizadas por pessoas "de fora", seja por estudantes universitários, voluntários ou membros de organizações da sociedade civil. Das oito atividades identificadas no período de 2002 a 2008, duas, em cada uma das unidades, estavam em curso no momento das entrevistas - segundo semestre de 2008. Todas as demais, por diferentes razões, estavam suspensas.

Dois fortes indícios indicam mudanças na gestão das prisões em São Paulo e, ao longo desta pesquisa, diferentes autores emprestaram reflexões que permitem compreender essas mudanças ou adaptações.

O maior controle sobre o acesso indica que o segredo que envolve a prisão desde o seu nascimento foi intensificado. Parece haver mais a esconder dos olhares externos. A preocupação não pode dissimular ou esconder as precárias condições de vida ou a superlotação - essas informações estão dispostas nas páginas eletrônicas dos órgãos gestores.

As explicações para a intensificação do controle de acesso ao ambiente prisional surgiram ao longo deste texto, pelo entrecruzamento das entrevistas e reflexões teóricas. À 
primeira vista, pode-se concluir que o segredo seja o novo arranjo na organização das unidades, que lhes garante a ordem, baseado na partilha da autoridade entre funcionários do sistema e grupos organizados de presos. Mas esta não pode ser a razão principal, uma vez que a existência de tais grupos é do conhecimento público, seja por meio do noticiário da imprensa sobre sua ação interna e externamente aos muros da prisão, seja por meio de estudos acadêmicos. Certamente causa algum constrangimento aos governantes e também aos funcionários, mas nada tão forte que lhes estimule a buscar outras formas de gestão do cotidiano das prisões.

A outra possibilidade, que parece mais razoável, é que o controle de acesso visa a dissimular o fim do ideal de reabilitação. É verdade que as duas características estão relacionadas e são comuns a sistemas prisionais de diferentes países. É certo também que a prisão no Brasil nunca teve orientação nítida sobre sua capacidade de ser um programa de reabilitação. As atividades, educativas ou laborais, quando existiram, sempre foram fragmentadas, de reduzida abrangência e historicamente realizadas por iniciativas de caráter privado, em geral, por organizações filantrópicas vinculadas a igrejas. Aliás, é difícil até mesmo mensurar sua abrangência, pois não há informações oficiais sobre elas, e as referências estão contidas, de forma assistemática, em diferentes estudos ou obras autobiográficas de pessoas que estiveram presas ou atuaram como voluntárias em prisões.

De toda forma, verifica-se certo empenho das autoridades em demonstrar que algo está sendo feito para a reabilitação e, neste sentido, as atividades educativas são essenciais, como demonstra a cobertura da mídia. São informações fragmentadas, anúncios de atividades, planos, projetos. Muito pouco de concreto; nada sobre a abrangência das atividades em relação ao universo total da população carcerária; reduzidas informação sobre as condições materiais e o financiamento para as atividades. Mas, ainda assim, atesta a imprensa e também as entrevistas com gestores, algo está sendo feito.

Entrar na prisão, registrar as ações educativas, identificar sua abrangência, investigar as condições para sua realização, as formas de financiamento, os critérios de seleção demonstra que pouco, muito pouco está sendo feito. E, este pouco, não tem qualquer vinculação com o Estado. Ao contrário, o Estado tem operado para afastar as possibilidades de o Estado atuar. E talvez este seja o segredo, a razão do fechamento da prisão, identificado por diferentes atores.

Mas entrar, ainda que rapidamente, foi possível. Como também se tentou construir um quadro com base em informações dispersas, entrevistas com pessoas que realizam ou realizaram atividades educativas, outras que delas participaram ou, ainda, gestores, pessoas 
comprometidas que afirmam o ideal da reabilitação e buscam alcançá-lo individualmente por meio das parcerias com iniciativas privadas.

\section{Diálogo com as hipóteses}

E é esse conjunto de informações que dialoga com as hipóteses iniciais propostas nesta pesquisa, conforme apresentado a seguir.

Hipótese 1: A ausência de diretrizes nacionais que orientem as práticas educativas mantém o ordenamento e a gestão do sistema prisional no âmbito da iniciativa privada.

No momento de formulação dessa hipótese, no segundo semestre de 2005, o programa "Educando para a Liberdade", que, entre outras ações, estimulou a formulação do texto-base que resultará nas Diretrizes Nacionais para a Educação nas Prisões, não havia sido identificado no campo da pesquisa e estava ainda em seu início.

Portanto, o termo "diretrizes nacionais", na hipótese formulada, não se referia ao documento que está sendo apreciado pelo Conselho Nacional de Educação, nesta data, início de março de 2010. No entanto, é inegável que o processo de debate em torno da formulação do documento e o seu resultado final contribuem de forma decisiva para testar a hipótese inicial.

Foi verificada a incrível dificuldade de afirmar no texto-base para as Diretrizes a responsabilidade do Estado sobre a educação nas prisões, bem como a vinculação das atividades educativas aos sistemas públicos de ensino, para garantir a educação formal, e sua ação indutora para as atividades não formais.

Num primeiro momento, o debate pareceu estar assentado sobre um possível antagonismo entre a educação formal e a não formal. Mas como se demonstrou, a tensão era mesmo em torno da representação do Estado no ambiente prisional.

Não fosse o registro desse embate em torno da formulação do documento e seu resultado inscrito no texto-base, grande parte das informações e dados apresentados ao longo desta pesquisa apontaria para a confirmação da hipótese. Indicariam que a superação da precariedade, descontinuidade e fragmentação das atividades identificadas residiria na falta de orientação por parte do Estado.

No entanto, a realidade demonstrou que mesmo a formulação de Diretrizes não foi capaz de superar o caráter privado da educação nas prisões. E o texto-base é ambíguo, repleto 
de oscilações, que permitem a perpetuação de iniciativas privadas - entidades, pessoas voluntárias e outras - como responsáveis pelas atividades de educação.

Obviamente, essas são conclusões construídas com base nas informações existentes até esta data. Pode ser que o Conselho Nacional de Educação, na redação final do documento, imprima o caráter público à educação a ser ofertada nas prisões - houve mobilização de organizações da sociedade civil nesse sentido -, mas, ainda assim, somente a verificação empírica de sua implementação poderá demonstrar se o caráter privado da educação nas prisões será superado pela existência de uma norma reguladora.

Hipótese 2: Estado e sociedade civil têm diferente compreensão sobre o sentido das práticas educativas empreendidas no interior das prisões. Ocupar o tempo livre é a principal motivação do Estado para permitir a entrada da sociedade civil, e esta, por sua vez, crê que sua ação pode contribuir com o desenvolvimento humano.

A diversidade de atores que se articula em torno do termo sociedade civil indica também a pluralidade de orientações e missões institucionais, bem como as inúmeras motivações que levam pessoas ou entidades a desenvolverem atividades educativas em prisões. Por isso, não é possível afirmar uma única motivação da sociedade civil na prisão. Contribuir com o desenvolvimento humano ou com o processo de garantia da dignidade humana das pessoas presas foram objetivos explicitados nas ações identificadas nas duas unidades prisionais que se constituíram no campo pesquisado.

Mas o universo das atividades não formais de educação empreendidas nas prisões é muito mais amplo, como demonstraram tanto a análise de mídia quanto as entrevistas com os gestores e outros atores. Sob a denominação sociedade civil, ou comunidade, há indícios da atuação de interesses privados, com fins de transferência de recursos púbicos para a iniciativa privada.

Assim como a sociedade civil, também o Estado tem múltiplas representações no sistema prisional, o que torna impossível afirmar uma única intencionalidade em relação às atividades educativas. Há o Estado representado pelos gestores, que formulam leis e ações que visam a garantia dos direitos educativos; há o Estado representado por profissionais, que dificultam a realização das ações; há outros que tentam apoiar, ainda que individualmente.

O que se pode afirmar, com base no campo pesquisado, é que a atual configuração das prisões é propícia para que as poucas atividades educativas sejam parte integrante do sistema de privilégios, o que significa que podem ter o caráter de ocupar o tempo, mas também de garantir algum tipo de benefício ou bem-estar a quem participa do arranjo interno. 
Obviamente, qualquer que seja a intenção da atividade, o fato de ser vinculada ao sistema de privilégios é responsabilidade do Estado, seja por uma maneira deliberada de atuação de seus funcionários-representantes nas prisões, seja por sua omissão, na ausência ou insuficiência de seus funcionários-representantes.

A pesquisa também indicou a existência de organizações da sociedade civil para as quais a realização de atividades educativas é parte da estratégia de defesa dos direitos das pessoas encarceradas. A intencionalidade da ação extrapola os objetivos de produção ou transmissão de conhecimento, e as práticas educativas tornam-se meios de identificação de violações e busca de alternativas para sua superação.

Nesse caso, as características de controle inerentes às atividades educativas regularidade nos encontros, registro e controle da presença, necessidade de produção de trabalhos ou atividades que demonstrem a apreensão/produção do conhecimento, entre outras - são subvertidas em mecanismos de controle da prisão.

Hipótese 3: A diversidade, irregularidade e parcialidade das ações empreendidas pela sociedade civil, ordenadas pelo Estado, garantem a manutenção da prisão como espaço privado de contenção.

O campo pesquisado comprovou a diversidade, irregularidade e parcialidade das ações empreendidas pela sociedade civil. Também demonstrou que esta realidade é consolidada pela ação ou omissão do Estado, que se constituem em diferentes formas de ordenar. E estas duas condições resultariam na manutenção da prisão como espaço privado, no sentido de ausência de condutas que vinculem o espaço prisional às políticas públicas, vigentes na sociedade do além muros.

A hipótese estaria confirmada não fosse a insistência dos protagonistas de algumas das iniciativas em provocar o Estado a assumir a gestão das prisões por meio de políticas públicas. São pessoas ou organizações que integram sua atuação dentro das prisões a práticas de reivindicação de direitos. Transformam a realidade presenciada durante sua permanência na prisão em informação para subsidiar mobilizações por direitos, que se efetivam por meio das políticas públicas.

São pessoas ou instituições que exercem em plenitude seu caráter privado de interesse público. Portanto, são entes privados que buscam contribuir para que o espaço prisional seja ocupado pelo público.

Estava, entre as expectativas desta pesquisa, identificar possíveis critérios de diferenciação entre as práticas empreendidas nas unidades feminina e masculina. O universo 
pesquisado foi bastante restrito - apenas oito iniciativas identificadas nas unidades, além daquelas localizadas em outras fontes.

As ações verificadas nas duas unidades paulistas indicam que a unidade feminina abriga iniciativas desenvolvidas por organizações da sociedade civil vinculadas à defesa de direitos humanos. São práticas desenvolvidas por pessoas engajadas e com trajetória de militância política, o que confere às iniciativas um duplo sentido: produção de conhecimento e meio de ação política para a contestação do funcionamento das prisões, seja pelas propostas pedagógicas, que induzem à reflexão sobre o presente das mulheres, portanto, sobre o encarceramento, ou pela atuação dessas organizações além dos muros da prisão.

Já nas unidades masculinas verificou-se a maior incidência de pessoas voluntárias vinculadas a igrejas, que acreditam que sua prática possa contribuir para transformar os indivíduos, e não são propostas reflexões sobre a instituição prisional.

\section{Últimas palavras}

O período coberto por esta pesquisa permitiu identificar alguns sinais de mudança no campo da educação em prisões. Estes sinais, muitas vezes, parecem coerentes com as alterações percebidas por diversos autores, no Brasil e no mundo, na organização dos sistemas prisionais; mas, ao mesmo tempo, indicam a constituição de um campo, ainda incipiente, de análise, formulação de ações públicas e mobilização sobre a educação nas prisões.

De maneira geral, o cenário mundial, apontado por diversos autores, é de garantia formal de direitos à população carcerária, sendo que sua realização foi incluída entre os mecanismos de manutenção da ordem interna, compondo um sistema de privilégios, que funciona de maneira cooperativa entre funcionários do Estado e população carcerária, organizada e conduzida por lideranças.

O arranjo é uma adaptação que responde à pressão de grupos de defesa de direitos humanos e também às condições de encarceramento, impostas pela superlotação das instituições, sem a devida ampliação dos recursos materiais e humanos necessários ao controle da população. Não havendo a possibilidade de funcionários exercerem direta e integralmente o controle, a manutenção da ordem vem sendo assegurada pela partilha de poder entre o Estado e a própria população carcerária.

A superlotação, por sua vez, responde à necessidade de controle social sobre as camadas empobrecidas da sociedade, notadamente grupos étnico-raciais marginalizados, que 
passaram por sucessivos processos de exclusão social. Em alguns países que viveram o Estado de Bem-Estar no período do pós-guerra, a partir da década de 1970, o encarceramento em massa substituiu as políticas de assistência social daquele período.

No Brasil, as tendências que se verificam em âmbito internacional ganharam contornos peculiares, uma vez que a prisão nunca foi exatamente disciplina; também, diferentemente de outros países, as políticas de assistência social não foram, em momento algum, estendidas à população prisional, e o Estado nunca apresentou um projeto de reabilitação das pessoas encarceradas - tarefa historicamente assumida por organizações filantrópicas, destacadamente religiosas.

Dessa forma, a ampliação do encarceramento e as novas formas de gestão da ordem interna se somaram às péssimas condições de encarceramento que marcam a história da prisão no País.

Paralelamente a esse cenário, alguns sinais de mudança foram identificados ao longo do trabalho, focado apenas em uma das assistências formalmente garantidas pela Lei de Execução Penal: as práticas educativas.

O primeiro dos sinais, talvez, é o fato de, neste momento, ser possível identificar um campo, ainda que incipiente, destinado à formulação de ações públicas relacionadas à educação nas prisões - ainda não se pode falar em políticas, pois não há nenhuma ação universal destinada a toda a população carcerária -, de pesquisa e de mobilização social.

É inegável que o governo nacional assumiu a educação nas prisões como um campo específico de atuação. Projetos foram implementados, marcos regulatórios estimulados, produção de informação induzida, entre outras ações. A intensidade, abrangência, qualidade e consequência dessas ações ainda estão por ser analisadas, mas indicam mudança no comportamento de um setor de governo.

O tema - educação nas prisões - também vem ganhando espaço na produção de conhecimento, embora se identifique a necessidade de formulação de pesquisas que distingam as práticas formais daquelas não formais.

E, por fim, a pesquisa permitiu identificar uma forma de atuação da sociedade civil inesperada, talvez extemporânea: sua mobilização pela garantia dos direitos educativos das pessoas encarceradas. São poucas e frágeis manifestações, mas sinais, como as professoras e professores, de diferentes Estados, que vêm se organizando para chamar a atenção para a especificidade da sua prática pedagógica - seja na tentativa de constituir uma associação, na mobilização por condições de trabalho diferenciadas ou mesmo na denúncia dos limites impostos ao trabalho pedagógico na prisão. Ou, ainda, das organizações que estão se 
mobilizando para alterar a Lei de Execução Penal, de maneira a inscrever nesta lei a remição pelo estudo e a garantia do ensino público. E, por último, na produção e sistematização de informações para tornar públicas as condições de ensino e aprendizagem nas prisões.

São sinais, apenas sinais de mudança, que apontam para um novo cenário - o que não significa que a existência da prisão esteja sendo socialmente contestada ou que o ideal de reabilitação se tornará uma realidade. Significa apenas que, talvez, exista uma possibilidade de a prisão, no Brasil, passar por outra adaptação na sua organização, para acomodar novas formas de gestão da educação - formal e não formal - no seu interior. 


\section{REFERÊNCIAS}

A GAZETA (AC). Bolas do projeto Pintando a Liberdade chegam às escolas. 1 jun. 2005.

A GAZETA (MT). Erradicação do analfabetismo. 12 jan. 2003.

A NOTÍCIA (SC). Livros para presos. 7 set. 2003.

A NOTÍCIA (SC). Presos terão plano de saúde e Bolsa-escola. 3 abr. 2002.

A NOTÍCIA. Dois mil analfabetos nas prisões. 26 out. 2008.

A NOTÍCIA. Ensino médio em penitenciárias. 8 jul. 2002.

AÇÃO EDUCATIVA E OUTROS. Informe preliminar sobre Educação de Mulheres Encarceradas - Encontro Regional da América Latina de Educação em Prisões

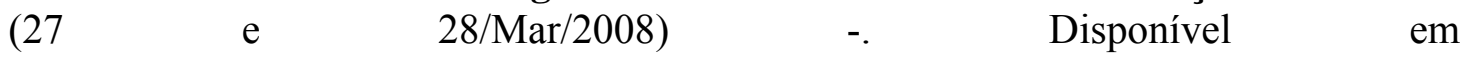
http://www.acaoeducativa.org.br/portal/index.php?option=com_content\&task=view\&i $\mathrm{d}=1216$. Acesso em 12 nov. 2009

AÇÃO EDUCATIVA. Preparação para a Conseg aponta para participação social e garantia de direitos. 30/7/2009. Disponível em: . http://www.acaoeducativa.org.br/portal/index.php?option=com_content\&task=view\&i $\mathrm{d}=1875$ \&Itemid=149. Acesso em 23 nov. 2009.

ADORNO, Sérgio. A gestão filantrópica da pobreza urbana. São Paulo em Perspectiva, São Paulo, v. 4, n.2, p. 8-17, abr./jun. 1990.

ADORNO, Sérgio. A prisão sob a ótica de seus protagonistas: itinerário de uma pesquisa. Tempo Social: Revista de Sociologia da USP, São Paulo, v. 3, n. 1 e 2, p.7-40, 1991.

ADORNO, Sérgio. Sistema penitenciário no Brasil: problemas e desafios. Revista USP, São Paulo, n. 9, p. 65-78, mar./abr./mai. 2001.

ADORNO, Sérgio; SALLA, Fernando. Criminalidade organizada nas prisões e os ataques do PCC. Estudos Avançados, São Paulo, v. 21, n. 61, p. 7-29, set./dez. 2007.

ADRIOLA, Wagner Bandeira et al. Proyecto educando para la libertad: la educación en estabelecimientos penitenciários bajo el análisis. In: UNESCO. Educación en prisiones en latinoamérica: derechos, libertad y ciudadanía. Brasília: UNESCO, 2008. p. 43-60.

ALVAREZ, Marcos César. Controle social: notas em torno de uma noção polêmica. São Paulo em Perspectiva, São Paulo, v.18, n. 1, p. 168-176, 2004.

ALVAREZ, Marcos César. Punição, poder e resistências: a experiência do Groupe d'information sur lês prisons e a análise crítica da prisão. In: SCAVONE, Lucila; ALVAREZ, Marcos César; MISKOLCI, Richard. O legado de Foucault. São Paulo: UNESP, 2006. p. 45-62.

ALVES, Marcio Moreira. A desigualdade digital. O Globo, Rio de Janeiro, 15 fev. 2004.

AMAZÔNIA Jornal. Presidiários usam educação ambiental para voltar ao convívio em sociedade. 3 abr. 2006

ARANTES, Valéria Amorim (Org.). Educação formal e não formal: pontos e contrapontos. São Paulo: Summus, 2008. 168 p. 
AZEVEDO, José Eduardo. Pensando a prisão em Michel Foucault. Disponível em: $<$ http://www.nu-sol.org/nu-sol/integrantes/jose/pensando_a_prisao.htm>. Acesso em: 19 jan. 2010.

BARBATO JÚNIOR, Roberto. Direito informal e criminalidade: os códigos do cárcere e do tráfico. Campinas: Millennium, 2006. 176 p.

BAUMAN, Zygmeunt. Modernity and the Holocaust. Grã-Bretanha. 1989

BAUMAN, Zygmunt. Globalização: as conseqüências humanas. Rio de Janeiro: Jorge Zahar Editor, 1999. 145 p.

BEISIEGEL, Celso de Rui. Estado e educação popular. 2 ed. São Paulo: Ática, 1989. 304 p.

BEISIEGEL, Celso de Rui. Política e educação popular. São Paulo: Biblioteca Pioneira de Ciências Sociais, 1974. 189 p.

BENEVIDES, Maria Victoria. A cidadania ativa. São Paulo: Ática, 1991. 208 p.

BENEVIDES, Maria Victoria. Cidadania e direitos humanos. In.: CARVALHO, José Sérgio (org.). Educação, cidadania e direitos humanos. Editora Vozes. São Paulo. 2004. p. 43-65.

BENEVIDES, Maria Victoria. Educação em direitos humanos: de que se trata? Disponível em: http://portal.mec.gov.br/seb/arquivos/pdf/Etica/9_benevides.pdf. Acesso em: 20 mar. 2010.

BENEVIDES, Maria Victoria. Educação para a democracia. 1996. Mimeo.

BENEVIDES, Maria Victoria. Os direitos humanos como valor universal. Lua Nova: Revista de Cultura e Política, São Paulo, n. 34, p. 179-188, 1994.

BETTELHEIM, Bruno. O coração informado. Rio de Janeiro: Paz e Terra, 1985. 233 p.

BLUMSTEIN, Alfred. Demographic factors: now in the future. In: Grouth and its influence on correctional policy. Guggenheim Criminal Justice Program, Berkeley, USA, 1991.

BOBBIO, Norberto. A era dos direitos. Rio de Janeiro: Campus, 1996. 217 p.

BOBBIO, Norberto. O conceito de sociedade civil. Rio de Janeiro: Edições Graal, 1982. 77 p.

BORGES, Priscilla. Biblioteca ambulante. Correio Braziliense, Brasília, 20 mai. 2003.

BRAGA, Ana Gabriela Mendes. Magia no cárcere: a possibilidade do encontro. Boletim do Instituto Brasileiro de Ciências Criminais, São Paulo, ano 14, n. 171, p. 11-12, fev. 2007.

BRASIL(a). Ministério da Justiça. Protocolo de intenções que entre si celebram Ministério da Justiça, o Serviço Nacional de Aprendizagem Industrial, o Serviço Social da Indústria, o Serviço Social do Comércio, o Serviço Nacional de Aprendizagem Comercial, e o Serviço Brasileiro de Apoio às Micro e Pequenas Empresas. 2007. Disponível http://portal.mj.gov.br/data/Pages/MJDA8C1EA2ITEMID8B687DE17F0D43C8B22B EE7558A78A89PTBRIE.htm. Acesso em: 20 out. 2009.

BRASIL(b). Ministério da Justiça. Protocolo de Intenções. 2007. Disponível em http://portal.mj.gov.br/data/Pages/MJDA8C1EA2ITEMID8B687DE17F0D43C8B22B EE7558A78A89PTBRIE.htm. Acesso em: 27 out. 2009. 
BRASIL. Controladoria Geral da União. Portal da Transparência. Disponível em: http://www.portaltransparencia.gov.br/convenios/ConveniosLista.asp?UF=SP\&Esta $\mathrm{do}=\mathrm{SAO}+\mathrm{PAULO} \&$ CodMunicipio $=\&$ CodOrgao $=30000 \&$ Orgao $=$ MINISTERIO + DA + JUSTICA\&TipoConsulta=1\&Periodo . Acesso em: 20 out. 2009.

BRASIL. Lei de Diretrizes e Bases da Educação, Lei n. 9.394 de 20 dez 1996.

BRASIL. Lei de Execução Penal, Lei n. 7.210 de 11 jul. 1984.

BRASIL. Ministério da Educação. Resolução n. 12 de 24 de abril de 2007. Disponível em: www.mec.gov.br . Acesso em: 30 out. 2009.

BRASIL. Ministério da Educação. Resolução n. 22 de 20 de abril de 2006. Disponível em: www.mec.gov.br . Acesso em: 30 out. 2009.

BRASIL. Ministério da Educação. Resolução n. 31 de 10 de agosto de 2006. Disponível em: www.mec.gov.br . Acesso em: 30 out. 2009.

BRASIL. Ministério da Justiça. Departamento Penitenciário Nacional (Depen/MJ). Sistema Nacional de Informação Penitenciária (Infopen). Disponível em: www.mj.gov.br . Acesso em: 21 out. 2009.

BRASIL. Ministério da Justiça. Fortalecimento e consolidação dos processos de gestão e pesquisa do Programa nacional de segurança pública com cidadania - Pronasci, com vista à ampliação de sua capacidade institucional na execução de ações educativas e de articulação entre segurança pública e políticas sociais desenvolvidas pela União, estados e municípios: Projeto de cooperação técnica internacional entre a Organização dos estados ibero-americanos para a educação, a ciência e a cultura - OEI. 2008. Disponível em: www.mj.gov.br . Acesso em: 20 out. 2009.

BRASIL. Ministério da Justiça. Programa Nacional de Direitos Humanos (PNDH I). Brasília, 1996.

BRASIL. Ministério da Justiça. Programa Nacional de Direitos Humanos (PNDH II). Brasília, 2002.

BRASIL. Ministério da Justiça. Protocolo de Intenções. 2007. Disponível em: www.mj.gov.br . Acesso em: 27 out. 2009.

BRASIL. Plano Nacional de Educação. Lei n. 10.172 de 9 jan. 2001.

BRASIL. Programa Nacional de Direitos Humanos - PNDH I. Ministério da Justiça. Brasília, DF. 1996.

BRASIL. Programa Nacional de Direitos Humanos - PNDH II. Ministério da Justiça. Brasília, DF. 2002.

BRASIL. Secretaria Especial dos Direitos Humanos da Presidência da República. Programa Nacional de Direitos Humanos (PNDH-3). ed. rev. Brasília: SEDH/PR, 2010. 228 p.

CAFARDO, Renata. Após 30 anos, São Paulo planeja pedagogia específica. O Estado de São Paulo, 8 mai. 2006.

CAFARDO, Renata. Crianças terão turno extra para praticar esportes. O Estado de São Paulo, 23 jul. 2003.

CALIMAN, Geraldo. A pedagogia social na Itália. In: SILVA, Roberto da; SOUZA NETO, João Clemente de; MOURA, Rogério Adolfo de. Pedagogia Social. São Paulo: Expressão e Arte, 2009. p. 51-60. 
CÂMARA FEDERAL. O Brasil e o Pacto Internacional de Direitos Econômicos, Sociais e Culturais: Relatório da sociedade civil sobre o cumprimento do Pacto. Brasília: Comissão de Direitos Humanos, 2000. 99 p.

CANDIDO, Antonio. O direito à literatura. In.: CARVALHO, José Sérgio (Org.). Educação, cidadania e direitos humanos. Petrópolis: Vozes, 2004. p. 130-158.

CANETTI, Elias. Massa e poder. São Paulo: Melhoramentos, 1983. 531 p.

CARNOY, Martin. Estado e teoria política. São Paulo: Papirus, 2001. 339 p.

CARREIRA, Denise. Educação nas prisões brasileiras. Relatoria Nacional para o Direito Humano à Educação/Plataforma Dhesca/Brasil. São Paulo, 2009. Mimeo. 110 p.

CARVALHO, José Sérgio (Org.). Educação, cidadania e direitos humanos. Petrópolis: Vozes, 2004. 373 p.

CASTEL, Robert. A dinâmica dos processos de marginalização: da vulnerabilidade à desfiliação. Caderno CRH, Salvador, n. 26/27, p. 19-40, jan./dez. 1997.

CEJIL E OUTROS. RELATÓRIO sobre Mulheres Encarceradas, apresentado à Comissão Interamericana de Direitos Humanos, fev/2007. Disponível em: http://www.ajd.org.br/documentos_ver.php?idConteudo=4. Acesso em: 30 nov 2009.

CHANTRAINE, Gilles. A prisão pós-disciplinar. Revista Brasileira de Ciências Criminais, São Paulo, n. 62, p. 79-106, 2006.

CHANTRAINE, Gilles; MARY Philippe. Prisons et mutations pénales, nouvelles perspectives d'analyse. Déviance et Societé, v. 30, n. 3, p. 267-271, 2006.

CHRISTIE, Nils. A indústria do controle do crime. Rio de Janeiro: Forense, 1998. 227 p.

CLAUDE, Richard Pierre. Direito à educação e educação para os direitos humanos. Sur, Rev. int. direitos human., São Paulo, v. 2, n. 2, 2005 . Disponível em: $<$ http://www.scielo.br/scielo.php?script=sci_arttext\&pid=S180664452005000100003\&lng=en\&nrm=iso>. Acesso em: 20 mar. 2010.

COLARES, Juliana. Educação como salvo-conduto para a liberdade. 9 jul. 2006

COLETIVO (DF). Escolas de Brasília participam de projeto social. 29 mar. 2005

COMPARATO, Fábio Konder. A afirmação histórica dos direitos humanos. São Paulo: Saraiva, 2003. 577 p.

COMPARATO, Fábio Konder. A nova cidadania. Lua Nova: Revista de Cultura e Política, São Paulo, n. 28-29, p. 85-106, 1993.

COMPARATO, Fábio Konder. Direitos humanos e Estado. In: FESTER, A. C. Ribeiro. Direitos Humanos e. São Paulo: Brasiliense, 1989.

COMPARATO, Fábio Konder. O princípio da igualdade e a escola. In: CARVALHO, José Sérgio (Org.). Educação, cidadania e direitos humanos. Petrópolis: Vozes, 2004. p. 66-84.

COOMANS, Fons. In search of the core elements of the right to education. 1999. Disponível em: www.right-to-education.org . Acesso em: março de 2003.

COOMBS, P.H; Ahmed, M.. A luta contra a pobreza rural: Contribuição da educação não formal. Madri: Tecnos, 1975.

CORREIO Braziliense. Literatura Comunitária. 28 fev. 2005. 
CORREIO da Paraíba. Preso custa no mês valor de aluno no ano. 19 ago. 2007.

CORREIO do Povo. Educação carcerária é desafio social. 27 jan 2003.

CORREIO do Povo. Fema leva inclusão digital ao presídio. 30 abr. 2006.

COSTA, Sérgio. As cores de Ercília. Belo Horizonte: UFMG, 2002. 220 p.

DAGNINO, Evelina (Org.). Sociedade civil e espaços públicos no Brasil. São Paulo: Paz e Terra, 2002. $364 \mathrm{p}$.

DALLARI, Dalmo de Abreu. Um breve histórico dos direitos humanos. In: CARVALHO, José Sérgio (Org.). Educação, cidadania e direitos humanos. Petrópolis: Vozes, 2004. p.19-42.

DE GIORGI, Alessandro. A miséria governada através do sistema penal. Rio de Janeiro: Reva, 2006. 128p. (Pensamento Criminológico, v.12)

DI PIERRO, Maria Clara. Descentralização, focalização e parceria: uma análise das tendências nas políticas públicas de educação de jovens e adultos. Educação e Pesquisa, São Paulo, v. 27, n. 2, p. 321-337, jul./dez. 2001.

DI PIERRO, Maria Clara; GRACIANO, Mariângela. A educação de jovens e adultos no Brasil: Informe apresentado à Oficina Regional da UNESCO para América Latina y Caribe. 2003.

DIÁRIO Catarinense. Falta projeto para educar presos cares. 26 out. 2008.

DIÁRIO Catarinense. Se não construirmos escolas, teremos de construir presídios. 16 jul. 2007.

DIÁRIO Catarinense. Unesco visita projeto Crisálida. 28 jan. 2003.

DIÁRIO da Manhã. Projeto de esportes na escola inicia em Goiânia. 24 jul. 2003.

DIÁRIO de Cuiabá. Mais de 400 vagas em aulas para detentos. 4 nov. 2007.

DIÁRIO de Pernambuco. Alunos terão acesso a esportes. 23 jul. 2003.

DIÁRIO de Pernambuco. BB quer levar inclusão à zona rural. 13 abr. 2005.

DIÁRIO de Pernambuco. Expansão ainda limitada. 9 jul. 2006.

DIÁRIO do Nordeste. Ação integrada garante projeto para presidiários. 15 mar. 2005.

DIÁRIO do Nordeste. Projeto Arca das Letras é referência. 7 ago. 2005.

DONNELLY, J.; HOWARD, R.E. Assessing national human rights performance: a theoretical framework. Human Rights Quartely, Baltimore, v. 10, 1998.

DURKHEIM, Émile. A educação - sua natureza e função. In:

Educação e sociologia. São Paulo: Melhoramentos, 1972. p. 33-56.

DURKHEIM, Émile. Da divisão do trabalho social. São Paulo: Martins Fontes, 1995. 109 p.

ESCOLA DE ADMINISTRAÇÃO PENITENCIÁRIA. Breve resumo de nossa história. Governo do Estado de São Paulo. Disponível em: http://www.eap.sp.gov.br/historia.htm . Acesso em: 7 fev 2008

FERREIRA, Jota. PPAB. Detentos aprendem a fazer crochê! Jornal do Commercio, Recife, 22 nov. 2002. 
FICHTNER, Bernd. Pedagogia social e trabalho social na Alemanha. In: SILVA, Roberto da; SOUZA NETO, João Clemente de; MOURA, Rogério Adolfo de. Pedagogia Social. São Paulo: Expressão e Arte, 2009. p. 43-49.

FISHER, N. Focault et le droit, de l'hypotèse répressive a l'instrument de gouvernement: le cas de la retention administrative dans la France contemporaine, communication au colloque "La politique vue avec Foucault". Paris: Sciences-Po, CIR, 2004.

FOLHA de Boa Vista (RR). Presidiários vão trabalhar na reforma de escolas públicas. 16 jul. 2003.

FOLHA de S.Paulo. Com dinheiro de prêmio, ONG construirá creche e biblioteca em cadeia de RS. 14 abr. 2007.

FOLHA de S.Paulo. MEC vai aplicar provas a 749 presos da região de Ribeirão. 12 nov. 2008.

FOUCAULT, Michel. A verdade e as formas jurídicas. Rio de Janeiro: Nau, 2005. 160 p.

FOUCAULT, Michel. Estratégia, poder-saber: Ditos \& Escritos. Rio de Janeiro: Forense Universitária, 2006. 396 p.

FOUCAULT, Michel. Eu, Pierre Rivière, que degolei minha mãe, minha irmã e meu irmão. Rio de Janeiro: Edições Graal, 1977. 294 p.

FOUCAULT, Michel. Frente a los gobiernos, los derechos humanos. In:

La vida de los hombres infames: Ensayos sobre desviación y dominación. Madrid-Montevideo: Editoral Altamira, p 313-317.

FOUCAULT, Michel. Microfísica do poder. Rio de Janeiro: Graal, 1979. 295 p.

FOUCAULT, Michel. O nascimento da clínica. Rio de Janeiro: Forense Universitária, 2004. $231 \mathrm{p}$.

FOUCAULT, Michel. Vigiar e punir: História da violência nas prisões. Petrópolis: Vozes, 1987. $277 \mathrm{p}$.

FREIRE, Paulo. Educação como prática de liberdade. 14 ed. Rio de Janeiro: Paz e Terra, 1983. $150 \mathrm{p}$.

FREIRE, Paulo. Pedagogia da autonomia. Rio de Janeiro: Paz e Terra, 1996. 146 p.

FREIRE, Paulo. Pedagogia da indignação: cartas pedagógicas e outros escritos. São Paulo, Editora UNESP, 2000.

FREIRE, Paulo. Pedagogia do oprimido. 21 ed. Rio de Janeiro: Paz e Terra, 1987. 184 p.

FUNAP. Perfil do Preso no Estado de São Paulo. 2002a. 490 slides.

FUNAP. Perfil do Preso no Estado de São Paulo: Censo Demográfico. 2002b. 70 slides.

FUNAP. Presídios e educação: Anais do I Encontro de monitores de alfabetização de adultos presos do Estado de São Paulo. São Paulo: FUNAP, 1993.

FUNDAÇÃO SEADE. Disponível em: http://www.seade.gov.br/produtos/idr/menu_tema_4.php?opt=s\&tema=edu\&subtem $\mathrm{a}=1$. Acesso em: 10 fev. 2010.

GARLAD, David. Punishment and modern society: a study in social theory. Oxford. Claredon Press. 1995 
GARLAND, David. A cultura do controle: Crime e ordem social na sociedade contemporânea. Rio de Janeiro: Revan, 2008. 438 p.

GARLAND, David. As contradições da 'sociedade punitiva': o caso britânico. Revista de Sociologia e Política, Curitiba, n. 13, p.58-80, 1999.

GENEVOIS, Margarida Bulhões Pedreira. Os direitos humanos na História. Alfabetização e Cidadania, São Paulo, n. 7, p. 11-22, 1998.

GENRO, Tarso. Participação para além do bairro. Proposta, Cidade, n. 69, 1996.

GIOBBI, César. O prazer da leitura. O Estado de S.Paulo. 12 fev. 2005.

GOFFMAN, Erving. Manicômios, prisões e conventos. São Paulo: Perspectiva, 2005. 312 p.

GOHN, Maria da Glória. Educação não formal e cultura política. São Paulo: Cortez, 2008. $120 \mathrm{p}$.

GOHN, Maria da Glória. Movimentos sociais e educação. 6 ed. São Paulo: Cortez, 2005. $117 \mathrm{p}$.

GOMES, Luiz Flávio. Prefácio. In: CHRISTIE, Nils. A indústria do controle do crime. Rio de Janeiro: Forense, 1998. p. XI-XVII.

GOVERNO do Estado de São Paulo. Decreto No 45.403 de 16 nov. 2000.

GOVERNO do Estado de São Paulo. Decreto No 47.169, de $1^{\circ}$ out. 2002.

GOVERNO do Estado de São Paulo. Decreto No 47.840, de 23 mai 2003.

GOVERNO do Estado de São Paulo. Decreto No 54.341, de 18 mai 2009.

GOVERNO do Estado de São Paulo. Secretaria de Administração Penitenciária. Relatório apresentado pela SAP/SP, como parte das determinações contidas no Pronasci. Disponível

em http://portal.mj.gov.br/data/Pages/MJE7CD13B5ITEMID2AC5EC2AC7834C729B14 65BE75D88371PTBRIE.htm. Acesso em: 12 fev. 2010.

GOVERNO do Estado de São Paulo. Secretaria de Administração Penitenciária. Resolução $\mathrm{N}^{\mathrm{o}} 59$, de 13 jun. 2003.

GOVERNO do Estado de São Paulo. Secretaria de Gestão Pública do Governo do Estado de São Paulo Absenteísmo. Disponível em www.recursoshumanos.sp.gov.br/qualidadedevida/absenteísmo/absenteismo.htm Acesso em: 20 out. 2009.

GOVERNO do Estado de São Paulo. Secretaria de Planejamento. Orçamento do Estado de São Paulo. Disponível em: http://www.planejamento.sp.gov.br/planorca/orca.aspx\#. Acesso em 15 jan. 2010.

GRACIANO, Mariângela. A educação como direito humano: a escola na prisão. Dissertação de Mestrado. Faculdade de Educação da USP. 2005. 165p.

GRACIANO, Mariângela; GONZALEZ, Marina; MODÉ, Giovanna. A cobertura da educação na mídia - algumas recomendações para a democratização do debate. Observatório da Educação/Ação Educativa. 2007. Disponível em: $<$ http://www.observatoriodaeducacao.org.br/images/publicacoes/pdfs/coberturadaeduc acao.pdf $>$. Acesso em: 20 jun. 2009. 
YAMAMOTO, Aline; GONÇALVES, Ednéia; GRACIANO, Mariângela; LAGO, Natália e ASSUMPÇÃO, Raiane. Educação em prisões. São Paulo : AlfaSol : Cereja, 2010. $128 \mathrm{p}$.

HADDAD, Sérgio (Coord.). Ensino Supletivo no Brasil: o estado da arte. Brasília: INEP/Reduc, 1987. $136 \mathrm{p}$.

HADDAD, Sérgio (Org.). Educação não-escolar de jovens e adultos. Revista e-curriculum, São Paulo, v.5, n.1, dez. 2009. Disponível em: <http://www.pucsp.br/ecurriculum>. Acesso em: $27 \mathrm{dez} 2009$.

HADDAD, Sérgio. Educação de Jovens e Adultos no Brasil (1986-1998). Brasília: MEC/INEP/Comped, 2002. 140 p. (Série Estado do Conhecimento).

HADDAD, Sérgio. Relatório síntese da pesquisa 'Diagnóstico do ensino supletivo no Brasil - período de 1971-1985. São Paulo: CEDI, 1987. 99 p. + anexos.

HADDAD, Sérgio. A atuação das ONGs no Brasil. In: EIXOS - Responsabilidade social e cidadania: A contribuição alemã. São Paulo : Instituto de Fomento Sócio-cultural Brasil-Alemanha/Câmara Brasil Alemanha, 2002. 135 p.

HADDAD, Sérgio. Education for younth and adults, for the promotion of na active citizenship, and for the development of a culture and aconscience of peace and human rights. In: Agenda for the future six years later: ICAE Report. Montevideo: ICAE, 2003b. 156 p.

HADDAD, Sérgio. Separação entre as perspectivas econômica e social impõe limites ao desenvolvimento latino-americano. In: KRAWCZK, Nora Rut et al. (Orgs.). América Latina: Estado e reformas numa perspectiva comparada. São Paulo: Cortez/PUC, 2003a. p 69-82.

HADDAD, Sérgio; DI PIERRO, Maria Clara. Diagnóstico dos estudos e pesquisas sobre políticas, estrutura e funcionamento do ensino supletivo na função suplência: Relatório final. São Paulo: CEDI, v. 1 - 3, 1988.

HADDAD, Sérgio; DI PIERRO, Maria Clara; FREITAS, Maria Virgínia de. Diagnóstico do ensino supletivo no Brasil - período de 1971-85: Relatório final - Anexos. São Paulo: CEDI, v. 1 - 2, 1987.

HADDAD, Sérgio; DI PIERRO, Maria Clara; FREITAS, Maria Virgínia de. Ensino supletivo no Brasil: o estado da arte. Brasília: INEP/Reduc, 1987. 136 p.

HADDAD, Sérgio; FREITAS, Maria Virgínia de. Diagnóstico dos estudos e pesquisas sobre cursos supletivos: Função suplência, via rádio, televisão e correspondência. São Paulo: CEDI, 1988. 159 p.

HADDAD, Sérgio; PIERRO, Maria Clara Di. Escolarização de jovens e adultos. Revista Brasileira de Educação, Rio de Janeiro, n. 14, p. 108-130, mai/jun/jul/ago. 2000.

HENRIQUES, Ricardo; SILVA, Fábio Sá; GRACIANO, Mariângela. Educação em prisões. O Globo, Rio de Janeiro, 4 ago. 2008.

JOCENIR. Diário de um detento. São Paulo: Labortexto Editorial, 2001. 184 p.

JORNAL de Brasília. Ensino chega aos presídios. 14 jul. 2006.

JORNAL de Brasília. Escolas nas penitenciárias. 18 jan. 2006.

JORNAL do Brasil. Bola na rede. 23 abr. 2003. 
JORNAL do Brasil. Herança Bendita. 16 jul. 2003.

JORNAL do Brasil. Ministro entrega kits esportivos a 326 escolas. 6 abr. 2003.

JORNAL do Commercio (PE). Educação para libertar. 28 out. 2008.

JORNAL do Commercio (PE). Em 2001, Bolsa-Escola inscreveu 1.996 crianças. 22 jan. 2002.

JORNAL do Commercio (PE). Indicador não mede impacto de programa para alfabetizar adulto. 16 dez. 2005.

JORNAL do Commercio. Existe educação nos presídios? 28 out. 2008.

JORNAL do Commercio. Presidiários do Estado sem acesso à educação. 30 out. 2008.

JORNAL do Senado. Comissão aprova ensino de música obrigatório na educação básica. 5 dez. 2007.

JORNAL do Senado. Comissão de Educação aprova salas de aula em presídios. 18 abr. 2007.

KLINGL, Erika. Aula em troca da pena. 12 jul. 2006.

KOERNER, Andrei. Punição, disciplina e pensamento penal no Brasil do século XIX. Lua Nova, São Paulo, n. 68, 2006 . Disponível em: $<$ http://www.scielo.br/scielo.php?script=sci_arttext\&pid=S010264452006000300008\&lng=en\&nrm=iso>. Acesso em: 20 mar. 2010.

KOERNER, Andrei. Punição, disciplina e pensamento penal no Brasil do século XIX. In.: Lua Nova: Revista de Cultura e Política. No 68. São Paulo. 2006. Disponível em: www.scielo.br/scielo.php?scripti=sci_arttext\&pid=S0102-644452006000300008\&1 Acesso em: 24 abr 2008.

LARANJEIRA, Denise Helena; TEIXEIRA, Ana Maria Freitas. Vida de jovens: educação não-formal e inserção socioprofissional no subúrbio. Revista Brasileira de Educação, São Paulo, v. 13, n. 37, p. 22-34, jan./abr. 2008.

LEAL, Luciana Nunes. O computador vai à favela. O Estado de São Paulo, São Paulo, 2 jun. 2002.

LEITÃO, José. Brasil Alfabetizado para presidiários. 2005. Disponível em: $<$ http://www.gruhbas.com.br/noticias.asp?codigo=1404>. Acesso em 12 dez. 2009.

LEVI, Primo. É isto um Homem? Rio de Janeiro: Rocco, 1988. 175 p.

LIMA Jr, Jayme Benvenuto. A emergência dos direitos econômicos, sociais e culturais no Brasil. In: Direitos Humanos no Brasil. Rio de Janeiro: Centro de Justiça Global. 2000.

MACEDO, Fernanda. Educação nos presídios é senha para ressocialização. Correio da Bahia, Salvador, 24 jul. 2006.

MANNHEIM, Karl; STEWART, W. A. C. Introdução à sociologia da educação. 2 ed. São Paulo: Cultrix,1962. 202 p.

MARIZ, Renata. Palavras do cárcere. Correio Braziliense, Brasília, 30 out. 2007.

MARTINS, José de Souza. Exclusão social e a nova desigualdade. São Paulo: Paulus, 1977. p. 7-59.

MEIO Norte (PI). Projeto oferece aula para detentos. 10 fev. 2005. 
MENDES, Luiz Alberto. Às cegas. São Paulo: Companhia das Letras, 2001. 478 p.

MENDES, Luiz Alberto. Memórias de um sobrevivente. São Paulo: Companhia das Letras, 2005. $356 \mathrm{p}$.

MITFORD, Jessica. The american prison business. Grã-Bretanha, 1974 (publicado nos EUA, em 1971, como Kind and usual punishment)

MONTESQUIEU. O espírito das leis. São Paulo: Abril Cultural, 1973, 569 p. (Os Pensadores, Livro Quatro).

MORAES, Reginaldo C. Reformas neoliberais e políticas públicas: hegemonia ideológica e redefinição das relações Estado-Sociedade. Educação \& Sociedade, Campinas , v. 23, p. 13-23, 2002. Número especial.

MORAES, Rita. Indicadores do Bem. Revista IstoÉ, São Paulo, 27 mai. 2005.

MOTTA, Manoel Barros. Apresentação. In: FOUCAULT, Michel. Estratégia, poder-saber: Ditos \& Escritos: Forense Universitária, 2006. p. XXX-XXXI.

MUÑOZ, Vernor. Do direito à justiça. In: HADDAD, Sérgio; GRACIANO, Mariângela. A educação entre os direitos humanos. Campinas: Autores Associados, 2005. p. 43-60.

MUÑOZ, Vernor. El derecho a la educación de las personas privadas de libertad. ONU. 2009

NASCIMENTO. André. Apresentação à edição brasileira. In: GARLAND, David. A cultura do controle. Rio de Janeiro: Revan, 2008. p. 7-30.

NISKIER, Arnaldo. Nem tudo está perdido. Jornal do Commercio, Rio de Janeiro, 12 ago. 2006.

NOGUEIRA, Marco Aurélio. Sociedade civil: entre o político-estatal e o modelo gerencial. Revista Brasileira de Ciências Sociais, São Paulo, v. 18, n. 52, p. 185-202, jun. 2003.

NÚÑEZ, Violeta. Participación y educación social. In: SILVA, Roberto da; SOUZA NETO, João Clemente de; MOURA, Rogério Adolfo de. Pedagogia Social. São Paulo: Expressão e Arte, 2009. p. 241-256.

O ESTADO de Minas. Lei obriga abertura de escolas nos presídios. 28 nov. 2002.

O ESTADO de Minas. Ministros discutem ensino no Mercosul. 21 nov. 2006.

O ESTADO de S. Paulo. Presos vão ajudar a construir novas escolas estaduais. 30 ago. 2005.

O GLOBO. CCJ aprova instalação de salas de aula em cadeias. 3 abr. 2008.

O GLOBO. Governo lança plano de saúde para presidiários. 3 abr. 2002.

O GLOBO. Muito além das aulas de informática. 11 abr. 2003.

O PARANÁ. Notas. 4 abr. 2008.

O’DONNELl, Guillermo. Democracia, Desarrollo Humano y Derechos Humanos (versión revisada de la ponencia presentada en el taller desarrollado en Heredia, Costa Rica, 1 y 2 de feb de 2002) mimeo.

OBSERVATÓRIO da Educação. Atividades no FSM 2009 resultam na criação de grupo de trabalho sobre educação nas prisões. Disponível em: http://www.observatoriodaeducacao.org.br/index.php?option $=$ com_content\&view $=$ arti cle\&id=621:atividades-no-fsm-2009-resultam-na-criacao-de-grupo-de-trabalho-sobre- 
educacao-nas-prisoes $\&$ catid $=64$ :eja-e-educacao-nas-prisoes $\&$ Itemid=102. Acesso em: 23 nov. 2009.

OLIVEIRA, Marina. Meninas iluminadas. Correio Braziliense, 12/01/2003

ONOFRE, Elenice Maria Cammarosano. Educação escolar na prisão. Para além das grades: a essência da escola e a possibilidade de resgate da identidade do homem aprisionado. Faculdade de Ciências e Letras, UNESP/Araraquara. 2002

ONOFRE, Elenice Maria Cammarosano. Escola na prisão: espaço de construção de identidade do homem aprisionado? In: (Org.). Educação escolar entre as grades. São Carlos: EdUFSCar, 2007. 160 p.

ORGANIZAÇÃO DAS NAÇÕES UNIDAS. Pacto Internacional sobre Direitos Econômicos, Sociais e Culturais. 1966

ORGANIZAÇÃO DAS NAÇÕES UNIDAS. Conselho Econômico e Social. Resolução 663 C I (XXIV), 1957.

ORGANIZAÇÃO DAS NAÇÕES UNIDAS. Conselho Econômico e Social. Resolução 20. 1990

ORGANIZAÇÃO DAS NAÇÕES UNIDAS. Conselho Econômico e Social. Resolução 24. 1990

ORGANIZAÇÃO DAS NAÇÕES UNIDAS. Conselho Econômico e Social. Resolução 2076 (LXII), 1977.

ORGANIZAÇÃO DAS NAÇÕES UNIDAS. Declaração Universal dos Direitos Humanos. 1948.

ORGANIZAÇÃO DAS NAÇÕES UNIDAS. Protocolo Adicional à Convenção Americana sobre Direitos Humanos sobre os Direitos Econômicos, Sociais e Culturais. 1988

ORGANIZAÇÃO DAS NAÇÕES UNIDAS. Regras mínimas para o tratamento de prisioneiros. 1955.

OTTO, Hans-Uwe. Origens da Pedagogia Social. In: SILVA, Roberto da; SOUZA NETO, João Clemente de; MOURA, Rogério Adolfo de. Pedagogia Social. São Paulo: Expressão e Arte, 2009. p. 29-42.

PADILHA, Paulo Roberto. Educação em direitos humanos sob a ótica de Paulo Freire. In.: Schilling, Flávia (org.) Direitos humanos e educação - outras palavras, outras práticas. São Paulo : Cortez. 2005. p. 166-176.

PARREIRAS, Mateus. Preso argentino tem até aula de sociologia. Hoje em Dia, Cidade, 23 nov. 2006.

PATTO, Maria Helena de Souza. Escolas cheias, cadeias vazias: Nota sobre as raízes ideológicas do pensamento educacional brasileiro. Estudos Avançados, São Paulo, v. 21, n. 61, p. 243-266, set./dez. 2007.

PERUZZO, Cicilia M.Krohling. Comunicação Comunitária e Educação para a Cidadania.

$<$ https://encipecom.metodista.br/mediawiki/images/b/bf/Cicilia_Peruzzo.pdf.>. Acesso em 8 jan. 2010.

PINHEIRO, Maria Francisca. O público e o privado na educação: um conflito fora de moda? In: FÁVERO, Osmar (Org.). A educação nas constituintes brasileiras: 1823/1988. Campinas: Autores Associados, 1996. p. 255-292. 
PIOVESAN, Flávia. Temas de direitos humanos. 2 ed. São Paulo: Moisés Limonad, 2002. $447 \mathrm{p}$.

PONTUAL, Pedro. Possibilidades e limites da participação. In: GRACIANO, Mariângela (Coord.). O Plano de desenvolvimento da educação. São Paulo: Ação Educativa, 2007. p. 49-51. (Em Questão, v. 4).

PORTUGUÊS, Manoel Rodrigues. Educação de adultos presos: possibilidades e contradições da inserção da educação escolar nos programas de reabilitação do sistema penal de São Paulo. Dissertação de Mestrado, Faculdade de Educação USP. 2001

PRADO, Antonio Carlos. Cela forte mulher. São Paulo: Labortexto Editorial, 2003. 216 p.

PROGRAMA Estadual de Direitos Humanos do Estado de São Paulo - PEDH-SP. Secretaria Estadual de Justiça do Estado de São Paulo. SP. 1997.

RIBEIRO, Marlene. Exclusão e educação social: conceitos em superfície e fundo. In: SILVA, Roberto da; SOUZA NETO, João Clemente de; MOURA, Rogério Adolfo de. Pedagogia Social. São Paulo: Expressão e Arte, 2009. p. 159-178.

ROMANO, Roberto. Educação e direitos humanos. In: Direitos humanos - visões contemporâneas. São Paulo: Associação Juízes para a Democracia, 2001. p. 123-133.

ROSE, Nikolas. The death of the social? Re-figuring the territory of government. Economy and Society, v. 25, n. 3, p. 327-356, ago. 1996.

RUSCHE, Georg; KIRCHHEIMER, Otto. Punição e estrutura social. 2 ed. Rio de Janeiro: Revan, 2004. 282 p.

RYYNÄNEN, Sanna. A pedagogia social na Finlândia e contexto brasileiro. In: SILVA, Roberto da; SOUZA NETO, João Clemente de; MOURA, Rogério Adolfo de. Pedagogia Social. São Paulo: Expressão e Arte, 2009. p. 61-81.

SALGADO, Maria Umbelina Caiafa; AGUIAR, Alexandre (Orgs.). Manual do Educador: Orientações Gerais. Brasília: Programa Nacional de Inclusão de Jovens: ProJovem Urbano, 2009. 144 p.

SALLA, Fernado; GAUTO, Maitê; ALVAREZ, Marcos César. A contribuição de David Garland: a sociologia da punição. Tempo Social: Revista de Sociologia da USP, São Paulo, v. 18, n. 1, p. 329-350, 2006.

SALLA, Fernando. A retomada do encarceramento, as masmorras high tech e a atualidade do pensamento de Michel Foucault. In: BIROLI, Flávia; ALVAREZ, Marcos César. Michel Foucault: histórias e destinos de um pensamento. Cadernos FFC, São Paulo, v.9, n. 1, p. 35-58, 2000.

SALLA, Fernando. De Montoro a Lembo: as políticas penitenciárias em São Paulo. Revista Brasileira de Segurança Pública, São Paulo, ano 1, p. 72-90, 2007.

SALLA, Fernando. O encarceramento em São Paulo: das enxovias à Penitenciária do Estado. Tese de Doutorado, Faculdade de Filosofia, Letras e Ciências Humanas, USP. São Paulo. 1997. 350 p.

SÃo PAUlO (Governo). Secretaria de Planejamento. Orçamento do Estado de São Paulo. Disponível em: <http://www.planejamento.sp.gov.br/planorca/orca.aspx\#>. Acesso em: 15 jan. 2010.

SÃO PAULO (Governo). Decreto n. 45.403 de 16 nov. 2000. 
SÃO PAULO (Governo). Decreto n. 47.169 de $1^{\circ}$ out. 2002.

SÃO PAULO (Governo). Decreto n. 47.840 de 23 mai. 2003.

SÃO PAULO (Governo). Decreto n. 54.341 de 18 mai 2009.

SÃO PAULO (Governo). Secretaria de Administração Penitenciária. Relatório apresentado pela SAP/SP, como parte das determinações contidas no Pronasci. Disponível em: http://portal.mj.gov.br/data/Pages/MJE7CD13B5ITEMID2AC5EC2AC7834C729B1 465BE75D88371PTBRIE.htm . Acesso em: 12 fev. 2010.

SÃO PAULO (Governo). Secretaria de Administração Penitenciária. Resolução n. 59, de 13 de junho de 2003.

SÃO PAULO (Governo). Secretaria de Gestão Pública. Absenteísmo. Disponível em: $<$ www.recursoshumanos.sp.gov.br/qualidadedevida/absenteísmo/absenteismo.htm>. Acesso em: 20 out. 2009.

SCARFÓ, Francisco. Los fines de la educación básica en cárceles en la provincia de Buenos Aires. La Plata: Universitaria de La Plata, 2008. 160 p.

SCARFÓ, Francisco. O papel da sociedade civil na garantia da educação nas prisões. Observatório da Educação/Ação Educativa. Disponível em: <www.observatoriodaeducacao.org.br>. Acesso em 15 abr. 2009.

Schilling, Flávia (org.) Direitos humanos e educação - outras palavras, outras práticas. São Paulo : Cortez. 2005. 264p.

SCHILLING, Flávia. Estudos sobre resistência. Dissertação de Mestrado, Faculdade de Educação/Unicamp. 1991

SCHILLING, Flávia. Violência - emergência: um cenário de confrontos. Perspectivas, São Paulo, v. 31, p. 13-28, jan./jun. 2007.

SCHILLING, Flávia; RIBEIRO, Cintia. Um convite: pensar é resistir. 2008. Mimeo. 12 p.

SEN, Amartya. Desenvolvimento como liberdade. São Paulo: Companhia das Letras, 2000. $410 \mathrm{p}$.

SENA, Paulo de. Assistência educacional nos estabelecimentos penais. Estudo elaborado pela Consultoria Legislativa da Câmara dos Deputados. Brasília-DF, julho de 2004. 31 p.

SHECAIRA, Sérgio Salomão. [Entrevista a Alamiro Velludo Salvador Netto]. Revista Liberdades, n. 3, p. 7-16, jan./abr. 2010.

SILVA, Roberto da; SOUZA NETO; João Clemente de; MOURA, Rogério Adolfo de. Pedagogia Social. São Paulo: Expressão e Arte Editora, 2009. 324p.

SINGER, Helena. Discursos desconcertados. Linchamentos, Punições e Direitos Humanos. São Paulo: FAPESP/ Humanitas, 2003. 387 p.

SOARES, Bárbara e ILGENFRITZ, Iara. Prisioneiras: vida e violência atrás das grades. Rio de Janeiro: Garamond. 2002. 150 p.

SOARES, Ismar de Oliveira. Educomunicação: um campo de mediações. In: Comunicação \& Educação, São Paulo, n. 19, p. 12-24, set./dez. 2000. Disponível em: $<$ http://200.144.189.42/ojs/index.php/comeduc/article/view/4147/3888>. Acesso em: 17 jan 2009. 
SOARES, Luiz Eduardo. A política nacional de segurança pública: histórico, dilemas e perspectivas. Estudos Avançados, São Paulo, v. 21, n. 61, p. 77-98, set./ dez. 2007.

SPITZER, Steven. Toward a Marxian Theory of Deviance. Social Problems. 1974. p. 638651.

SPOSITO, Marília Pontes. O povo vai à escola: a luta pela expansão do ensino público em São Paulo. São Paulo: Edições Loyola, 1984. 153 p.

STRATEgOS, Empresa Jr de Consultoria Política. Agenda Legislativa. Remição da pena pelo estudo. Jun. 2008. Mimeo.

TEIXEIRA, Alessandra. Do sujeito de direito ao estado de exceção: o percurso contemporâneo do sistema penitenciário brasileiro. Dissertação de Mestrado. Faculdade de Direito. USP. 2006. 174p.

TELES, Jorge, Duarte Daniele B. La evaluación como proceso: uma mirada sore el proyecto educando para la libertad. In: UNESCO. Educación en prisiones en Latinoamerica: Derechos, Libertad y Ciudadanía. UNESCO, 2008. p. 29-42.

TOMASEVSKI, Katarina. Human rights obligations: making education available, accessible, acceptable and adaptable. Right to educatin primers n. 3.2001. 43p

TRIBUNA do Brasil. Inscrições estão abertas. 27 abr. 2007.

TRIBUNA do Brasil. Penitenciária no SIA receberá 400 presos. 19 jun. 2007.

TRIBUNA do Planalto (GO). Escola: estudar ou trabalhar. 30 ago. 2006.

TRILLA, Jaume. A educação não formal. In: ARANTES, Valéria Amorim (Org.). Educação formal e não formal: pontos e contrapontos. São Paulo: Summus, 2008. p. 8-35.

UNESCO. Educación en prisiones en Latinoamerica: Derechos, libertad y ciudadanía. Brasília: UNESCO, 2008. 195 p.

UNESCO. Governo Japonês. Ministério da Educação. Ministério da Justiça. Educando para a liberdade: Trajetória, debates e proposições de um projeto para educação nas prisões brasileiras. Brasília: Editora, 2006. 70 p.

UNESCO. Marco de acción de Belém: Aprovechar el poder y el potencial del aprendizaje y la educación de adultos para un futuro viable. Brasília: UNESCO, 2009.

VARELLA, Drauzio. Estação Carandiru. São Paulo: Companhia das Letras, 1999. 297 p.

VARGAS, Jorge Osório. Educar em los derechos humanos, univesalismo y diferencia: hacia uma pedagogia de la ciudadanía em América Latina. México. 1998. Mimeo.

VARON, Ximena e UBAL, Marcelo. Aportes a las prácticas de educación no formal desde la investigación educativa. Ministério da Educação e Cultura do Uruguai. 2009

WACQUANT, Loïc. A ascensão do Estado penal nos EUA. Discursos Sediciosos, Rio de Janeiro, ano 7, n. 11, p. 15-41, $1^{\circ}$ sem. 2002.

ZERO Hora (RS). Informe do ensino. 8 dez. 2005.

ZERO Hora. Informe de ensino. 24 fev. 2005.

ZERO Hora. Informe do Ensino. 2 fev. 2007.

ZERO Hora. Pelo Rio Grande - Região Noroeste Santa Rosa. 30 abr. 2006 
ANEXOS

Anexo 1 - Teses e dissertação - 2000 a 2008

Anexo 2 - Roteiros da entrevistas

Anexo 3 - Programas de Laborterapia - População Carcerária de São Paulo - jun 2009

Anexo 4 - Convênios em andamento - Ministério da Justiça/Depen 


\section{Anexo 1}

Teses e Dissertações - Educação nas prisões: 2000 a 2008

ARAÚJO, Doracina Aparecida de Castro. Educação escolar no sistema penitenciário de Mato Grosso do Sul: um olhar sobre Paranaíba. Tese de Doutorado. Unicamp. 2005. $213 p$

CAMPESTRINI, Bernadétte Beber. Aprender e ensinar nos espaços prisionais: uma alternativa para a Educação a Distância, incluir jovens e adultos no processo de escolarização. Dissertação de Mestrado, Florianópolis: UFSC. 2002

CAMPESTRINI, Bernadétte Beber. Reeducar, reinserir e ressocializar por meio da educação a distância. Tese de Doutorado, UFSC. 2007. 146p.

CARVAlHO, Ana Lúcia Luna. Terapia Ocupacional na Readaptação Profissional do Preso do Sistema Penal: Um Estudo da Prisão Provisória de Curitiba. Dissertação de Mestrado, Universidade da Região de Joinville. 2003. 133p

FIORE, Miriam Rodrigues. A Educação na Penitenciária Feminina da Capital: a crença da reabilitação. São Paulo, Dissertação de Mestrado, Universidade São Marcos. 2003

FRANÇA, Fátima. Prestação de Serviço à comunidade: um recurso de punição ou de desenvolvimento pessoal. Dissertação de Mestrado, Faculdade de Psicologia-USP. 2000. $167 \mathrm{p}$

GRACIANO, Mariângela. A educação como direito humano: a escola na prisão. Dissertação de Mestrado, FE-USP, 2005

JULIÃO, Elionaldo. "Política pública de Educação Penitenciária: contribuição para o diagnóstico da experiência do Rio de Janeiro". Dissertação de Mestrado, Faculdade de Educação PUC/RJ. 2003

LEITE, José Ribeiro. Educação por trás das grades: uma contribuição ao trabalho educativa, ao preso e à sociedade. Marília, São Paulo. Dissertação de Mestrado, UNESP. 1997

LEME, José Antonio Gonçalves. A 'cela de aula': tirando a pena com letras. Uma reflexão sobre o sentido da educação nos presídios. São Paulo. Dissertação de Mestrado, PUC/SP. 2002

LOURENÇO, Arlindo da Silva. As regularidades e as Singularidades dos Processos Educacionais no Interior de Duas Instituições Prisionais e Suas Repercussões na Escolarização de Prisioneiros: Um Contraponto à Noção de Sistema Penitenciário? Dissertação de Mestrado, PUC-SP. 2005. 220p

MATSUMOTO, Adriana Eiko. Sentidos e significados sobre educação em sistema prisional: o olhar de um preso-aluno. Dissertação de Mestrado, PUC-SP. 2005. $199 \mathrm{p}$

MUNEYMNE, Jhones Macario da Silva. A Educação de jovens e adultos no Sistema Penitenciário de Manaus: estudo de caso na cadeia pública Desembargador Raimundo Vidal Pessoa. Dissertação de Mestrado, UFAM. 2004. 189p 
NOGUEZ, Janaina Amorim. A libertação da minha alma sonhadora: experiências vivenciadas com as detentas da Penitenciária Estadual de Rio Grande. Dissertação de Mestrado, Fundação Universidade Federal do Rio Grande. 2006.162p

ONOFRE, Elenice Maria Cammarosano. Educação escolar na prisão. Para além das grades: a essência da escola e a possibilidade de resgate da identidade do homem aprisionado. Tese de Doutorado, Universidade Estadual Paulista Júlio de Mesquita Filho/Araraquara. 2002. 187p

PORTUGUÊS, Manoel Rodrigues. Educação de adultos presos: possibilidades e contradições da inserção da educação escolar nos programas de reabilitação do sistema penal do Estado de São Paulo. Dissertação de Mestrado, Faculdade de Educação-USP. 2001. 280p

QUELUZ, Emerson Lemke. Cela de Aula: espaço de ensino-aprendizagem. Dissertação de Mestrado, UFPR. 2006. 127p

RAMOS NETTO, Justino de Mattos. O direito à educação dos presos no Brasil: perspectivas do direito ao acesso à educação no sistema prisional e atual normatização processual e de execução penal. Dissertação de Mestrado, PUC-SP. 2006. 170 p

RESENDE, Selmo Haroldo. Vidas condenadas: o educacional na prisão. Tese de Doutorado. Faculdade de Educação, PUC/SP. 2002

SANCHES, Janaina G.. Aspectos do envelhecimento em indivíduos encarcerados e as oportunidades educacionais no sistema penitenciário. Dissertação de Mestrado, UERJ. 2001. 310p

SANTOS, S. A educação escolar no sistema prisional sob a ótica de detentos. Dissertação de Mestrado, Faculdade de Educação PUC/SP. 2002

SILVA, Ana Lúcia Gomes da. Educação carcerária: (des)encantos, (des)crenças e os(des)velamentos das histórias de leitura no cárcere, entre ditos, silêncios e subentendidos. Tese de Doutorado, UFBA. 2007. 216p

TORRES, Cláudia Regina Vaz. Desconstruindo a identidade de "criminoso(a)": o significado das ações educativas no sistema penitenciário. Dissertação de Mestrado, UFBA. 2004. 162p

VASQUEZ, Eliane Leal. Sociedade Cativa: entre cultura escolar e cultura prisional uma incursão pela ciência penitenciária. Dissertação de Mestrado, PUC-São Paulo. 2008. 


\section{Anexo 2}

\section{Roteiro das entrevistas}

\section{Quadro 1. Entrevista dirigente/a organização da sociedade civil}

1- Caracterização da/o entrevistada/o: Nome; Idade; Formação; Cargo e atribuições do cargo; Tempo de trabalho no sistema prisional; Porque trabalhar nas prisões?

2- Caracterizar a organização: Quando, como e por quem foi fundada?; Qual a sua missão institucional?; Há quanto tempo atua no sistema prisional?; Quais as principais atividades desenvolvidas?; Quais as fontes de financiamento?

3- Como estabelece relação com sistema prisional? SAP? Diretamente com dirigente da unidade?

4- Em quantas unidades atua?

5- Qual o objetivo da atuação no sistema prisional?

6- Como avalia o resultado do trabalho?

7- Qual a importância do trabalho para o sistema prisional?

8- Qual a importância do trabalho para as pessoas que participam das atividades?

9- A atividade promove mudanças no presente das pessoas? Como? Promove mudanças na visão de futuro?

10- Há avaliação sobre o resultado da atividade para os egressos que dela tenham participado? Qual é?

11- Quais as dificuldades verificadas para a realização da atividade?

12- Quais as facilidades encontradas?

\section{Quadro 2. Entrevista gestor e dirigente das unidades pesquisadas}

1- Caracterização da/o entrevistada/o: Nome; Idade; Formação; Cargo e atribuições do cargo; Tempo de trabalho no sistema prisional; Tempo de trabalho nesta unidade

2- Quais são as atividades desenvolvidas por organizações da sociedade civil nesta unidade?

3- Quais são as atividades desenvolvidas por voluntários nesta unidade?

4- Como se dão as parcerias? Quem procura?

5- Quais são os critérios para aceitar a atuação da sociedade civil nesta unidade?

6- Quem estabelece os critérios para realização das ações?

7- Há algum tipo de orientação da SAP sobre o tema?

8- Há algum tipo de orientação do ministério da justiça sobre o tema?

9- Qual o objetivo, segundo sua percepção, das ações da sociedade civil na unidade?

10- Quais os resultados dessas ações?

11- Qual a sua importância?

12- Como as ações interferem no cotidiano da unidade?

13- Qual a importância das ações para as pessoas que delas participam? 


\section{Quadro 3. Entrevista educador/a e/ou pessoa voluntária}

1- Caracterização da/o entrevistado: Nome; Idade; Formação; Cargo e atribuições do cargo; Tempo de trabalho no sistema prisional; Tempo de trabalho nesta unidade; Porque trabalhar na prisão?

2- Descrição da atividade: O que é?; Qual o objetivo?; Como é o planejamento?; Como se dá o financiamento?; Existe relação com atividades de educação formal?

3- Como são constituídas as turmas? Quais os critérios para participação/ seleção?

4- Qual a demanda?

5- Como é a relação com a turma?

6- Como avalia o interesse do grupo?

7- Como é a relação com os funcionários da unidade?

8- Como é a relação com os dirigentes da unidade?

9- Quais os resultados para as pessoas que participam?

10- A atividade tem alguma incidência sobre o presente das pessoas? Tem potencial para mudar o cotidiano? E para mudar o futuro?

11- Há avaliação sobre o resultado da atividade para os egressos que dela tenham participado? Qual é?

12- Quais as dificuldades verificadas para a realização da atividade?

13- Quais as facilidades encontradas?

\section{Quadro 4. Entrevista estudante}

1- Caracterizar a/o entrevistado/a: Nome. Idade; Formação/Escolaridade antes de ingressar no sistema; Formação/Escolaridade atuais; Origem (região, cidade, bairro); Trabalha na unidade? Onde? Trabalhava anteriormente? Quais foram as ocupações?; Freqüenta atividades de educação formal?; Por quê? Como avalia?; Período no sistema prisional; Perspectivas de saída do sistema prisional

2- De quantas atividades não formais participa? Descreva

3- Qual a sua opinião sobre elas?

4- Qual a sua importância para a sua vida presente?

5- Avalia que é importante para o futuro, fora da prisão?

6- Se freqüenta/ ou freqüentou a escola, o que percebe de comum entre as atividades formal e não formal?

7- Por que participa das atividades?

8- Quais atividades seriam importantes na prisão? Por quê?

9- Qual a sua avaliação sobre a educação na prisão? 


\section{Anexo 3 \\ Programas de Laborterapia - Sistema Prisional do Estado de São Paulo \\ Dados Infopen - Ministério da Justiça - jun. 2009 \\ Disponível em: www.mj.gov.br. Acesso em 5 jan. 2010}

\section{Trabalho Externo: Regime Semiaberto}

\subsection{Pessoas em programas de laborterapia - trabalho externo}

\begin{tabular}{|l|l|l|l|}
\hline & $\begin{array}{l}\text { População } \\
\text { Semiaberto }\end{array}$ & $\begin{array}{l}\text { Pessoas trabalhando } \\
\text { Atividades Externas }\end{array}$ & $\%$ \\
\hline Homens & 18.021 & 4.658 & 25,8 \\
\hline Mulheres & 1.279 & 142 & 11,1 \\
\hline Total & 19.300 & 4.800 & 24,9 \\
\hline
\end{tabular}

Dados produzidos com base nas informações disponíveis em: < http:/www.mj.gov.br $>$.

\subsection{Trabalho externo - de acordo com tipo de atividade}

\begin{tabular}{|l|l|l|l|}
\hline Tipo atividade & Masculina (\%) & Feminina (\%) & Total (\%) \\
\hline Parceria com iniciativa privada & 46,9 & 59,2 & 47,3 \\
\hline Parceria com órgãos do Estado & 20,3 & 28,8 & 20,6 \\
\hline Parceria com Paraestatais (Sistema S e ONG) & 3,2 & - & 3,1 \\
\hline Atividade Desenvolvida - Artesanato & 0,3 & 0,7 & 0,3 \\
\hline Atividade Desenvolvida - Rural & 3,7 & - & 3,6 \\
\hline Atividade Desenvolvida - Industrial & 25,6 & 11,3 & 25,1 \\
\hline
\end{tabular}

Dados produzidos com base nas informações disponíveis em: < http://www.mj.gov.br>.

\section{Trabalho interno: Presos Provisórios + Regime Fechado + Medida de Segurança (Internação)}

2.1Pessoas em programas de laborterapia - trabalho interno

\begin{tabular}{|l|l|l|l|}
\hline & $\begin{array}{l}\text { População Carcerária exceto regime } \\
\text { semiaberto }\end{array}$ & $\begin{array}{l}\mathrm{N}^{\mathrm{o}} \text { pessoas trabalhando } \\
\text { Atividades Internas }\end{array}$ & $\%$ \\
\hline Homens & 129.864 & 34.184 & 26,3 \\
\hline Mulheres & 9.540 & 2.879 & 30,2 \\
\hline Total & 139.404 & 37.063 & 26,6 \\
\hline
\end{tabular}

2.2 Trabalho interno - de acordo com tipo de atividade

\begin{tabular}{|l|l|l|l|}
\hline Tipo atividade & Masculina (\%) & Feminina (\%) & Total (\%) \\
\hline Apoio ao Estabelecimento Penal & 43,1 & 33,9 & 42,4 \\
\hline Parceria com a Iniciativa Privada & 38,2 & 47,3 & 38,9 \\
\hline Parceria com Órgãos do Estado & 3,5 & 12,3 & 4,2 \\
\hline Parceria com Paraestatais (Sistema “S” e ONGs) & 0,3 & 0,7 & 0,3 \\
\hline Atividade Desenvolvida - Artesanato & 6,8 & 5,8 & 6,7 \\
\hline Atividade Desenvolvida - Rural & 3,0 & - & 2,8 \\
\hline Atividade Desenvolvida - Industrial & 5,1 & - & 4,7 \\
\hline
\end{tabular}

Dados produzidos com base nas informações disponíveis em: < http:// www.mj.gov.br $>$. 


\begin{tabular}{|c|c|c|c|c|}
\hline \multicolumn{5}{|c|}{ CGRSE/DIRPP/DEPEN/MJ } \\
\hline & \multicolumn{4}{|c|}{ CONVÊNIOS EM ANDAMENTO } \\
\hline UF & Conv. $\mathrm{N}^{\circ}$. & Projeto & Convenente & Meta/Público Alvo \\
\hline BA & 059/2004 & $\begin{array}{l}\text { Curso de Especialização em } \\
\text { Gestão Prisional }\end{array}$ & Universidade do Estado da Bahia & 50 alunos \\
\hline PR & $062 / 2004$ & $\begin{array}{l}\text { Curso de Pós Graduação Latu } \\
\text { Sensu }\end{array}$ & $\begin{array}{l}\text { Fundação da Universidade Federal do Paraná para o } \\
\text { Desenvolvimento da Ciência, da Tecnologia e da Cultura }\end{array}$ & 50 alunos \\
\hline MS & $024 / 2005$ & $\begin{array}{l}\text { Implantação de Unidades de } \\
\text { Panificação em Estabelecimentos } \\
\text { Penais de Mato Grosso do Sul }\end{array}$ & Secretaria de Estado de Justiça e Segurança Pública & $\begin{array}{l}250 \text { pessoas em } 4 \\
\text { estabelecimentos prisionais. }\end{array}$ \\
\hline $\mathrm{PE}$ & $025 / 2005$ & Projeto Arca das Letras II & Secretaria de Defesa Social & $\begin{array}{c}37 \text { pessoas e produção de } 600 \\
\text { arcas }\end{array}$ \\
\hline ES & $004 / 2005$ & $\begin{array}{l}\text { Implantação e Implementação da } \\
\text { Escola Penitenciária do Espírito } \\
\text { Santo }\end{array}$ & Secretaria de Estado de Justiça & Implantação de escola. \\
\hline MA & $008 / 2005$ & Projeto Político Pedagógico & $\begin{array}{l}\text { Secretaria de Estado da Justiça e da Cidadania do } \\
\text { Maranhão }\end{array}$ & 1.285 servidores \\
\hline MS & $012 / 2005$ & $\begin{array}{c}\text { Implantação da Escola } \\
\text { Penitenciária no Estado de Mato } \\
\text { Grosso do Sul }\end{array}$ & Secretaria de Estado de Justiça e Segurança Pública & Implantação de escola. \\
\hline MT & $017 / 2005$ & $\begin{array}{c}\text { Implantação da Escola } \\
\text { Penitenciária no Estado de Mato } \\
\text { Grosso. }\end{array}$ & Secretaria de Estado de Justiça e Segurança Pública & Implantação de escola. \\
\hline PB & $009 / 2005$ & $\begin{array}{l}\text { Projeto Político Pedagógico da } \\
\text { Escola de Adfministração } \\
\text { Penitenciária. }\end{array}$ & Secretaria de Administração Penitenciária & 580 servidores \\
\hline PB & $010 / 2005$ & $\begin{array}{l}\text { Implantação de Escola de } \\
\text { Admnistração Penitenciária. }\end{array}$ & Secretaria de Administração Penitenciária & Implantação de escola. \\
\hline PR & $014 / 2005$ & $\begin{array}{l}\text { Curso Grupo de Apoio às Ações } \\
\text { Penitenciárias }\end{array}$ & Secretaria de Estado da Justiça e da Cidadania & 175 alunos \\
\hline RO & $011 / 2005$ & $\begin{array}{c}\text { Implantação de Escola de } \\
\text { Formação, Qualificação e } \\
\text { Capacitação dos Serviços } \\
\text { Penitenciários }\end{array}$ & Secretaria de Estado de Administração Penitenciária & Implantação de escola. \\
\hline RO & $018 / 2005$ & $\begin{array}{c}\text { Capacitação para os operadores do } \\
\text { Sistema Penitenciário no Estado de } \\
\text { Rondônia. }\end{array}$ & Secretaria de Estado de Administração Penitenciária & 946 servidores \\
\hline SE & $022 / 2005$ & $\begin{array}{l}\text { Implantação da Escola de } \\
\text { Administração Penitenciária }\end{array}$ & Secretaria de Estado da Justiça e da Cidadania de Sergipe & Implantação de escola. \\
\hline $\mathrm{CE}$ & $013 / 2006$ & Arca das Letras & Secretaria da Justiça e Cidadania & 600 arcas. e 20 pessoas \\
\hline $\mathrm{AL}$ & $016 / 2006$ & Mãos que Florescem & Secretaria Executiva de Ressocialização & 40 Pessoas \\
\hline MG & $017 / 2006$ & $\begin{array}{l}\text { Aquisição de Equipamentos de Saúde } \\
\text { para } 09 \text { Unidades Prisionais do Estado }\end{array}$ & Secretaria de Defesa Social & Aparelhamento de unidades. \\
\hline MA & 019/2006 & $\begin{array}{c}\text { Projeto Libertas - do Outro Lado do } \\
\text { Muro }\end{array}$ & Secretaria de Estado da Justiça do Maranhão & $\begin{array}{l}80 \text { privados de liberdade e } 20 \\
\text { familiares }\end{array}$ \\
\hline $\mathrm{CE}$ & 020/2006 & $\begin{array}{c}\text { Projeto "Brinquedoteca - A Arte de } \\
\text { Brincar" }\end{array}$ & Creche Amadeu Barros Leal & 100 crianças \\
\hline $\mathrm{RN}$ & $022 / 2006$ & Projeto Nascer da Terra & Secretaria de Estado da Justiça e da Cidadania & 60 pessoas \\
\hline GO & $023 / 2006$ & $\begin{array}{c}\text { Projeto Criação do Centro de } \\
\text { Excelência do Sistema de Execução } \\
\text { Penal }\end{array}$ & Secretaria de Estado da Justiça do Goiás & Implantação do Centro \\
\hline $\mathrm{AL}$ & $024 / 2006$ & $\begin{array}{l}\text { Projeto Político Pedagógico para a } \\
\text { Escola Penitenciária }\end{array}$ & Secretaria Executiva de Ressocialização & Implnatação da Escola \\
\hline $\mathrm{RN}$ & $026 / 2006$ & Projeto Arca das Letras & Secretaria de Estado da Justiça e da Cidadania & 20 Pessoas \\
\hline SE & $027 / 2006$ & $\begin{array}{c}\text { Programa de Qualificação Profissional } \\
\text { no âmbito da Justiça e Cidadania do } \\
\text { estado }\end{array}$ & Secretaria de Estado da Justiça e da Cidadania & 469 agentes \\
\hline SP & $028 / 2006$ & Em Defesa dos Direitos dos Presos & Defensoria Pública do Estado de São Paulo & 14.400 processos \\
\hline RO & $029 / 2006$ & Projeto Unidade de Saúde & Secretaria de Estado da Administração Penitenciária & Saúde \\
\hline $\mathrm{SC}$ & $030 / 2006$ & Novos Horizontes & Centro de Integração Empresa Escola - CIEE/SC & $\begin{array}{c}175 \text { privadas de liberdade e } 25 \\
\text { agentes }\end{array}$ \\
\hline
\end{tabular}




\begin{tabular}{|c|c|c|c|c|}
\hline GO & $031 / 2006$ & $\begin{array}{l}\text { Curso de Formação Específica em } \\
\text { Gestão do Sistema Prisional }\end{array}$ & Fundação Universitária do Cerrado & alunos \\
\hline $\mathrm{AM}$ & $033 / 2006$ & $\begin{array}{l}\text { Brinquedoteca - Brincar também é } \\
\text { Ressocializar }\end{array}$ & Secretaria de Estado da Justiça e Direitos Humanos & 161 reeducandos e 239 crianças \\
\hline MT & $034 / 2006$ & $\begin{array}{c}\text { Projeto "implantação de Fábricas de } \\
\text { Artefatos de Concreto Pré-moldados } \\
\text { nas Unidades Prisionais do Estado de } \\
\text { Mato Grosso }\end{array}$ & Secretaria de Estado de Justiça e Segurança Pública & 60 pessoas \\
\hline ES & 036/2006 & Maria Marias & Secretaria de Estado da Justiça do Espírito Santo & 310 mulheres \\
\hline GO & $037 / 2006$ & $\begin{array}{l}\text { Qualificação Profissional do } \\
\text { Reeducando }\end{array}$ & Secretaria da Justiça e Cidadania do Estado de Goiás & 400 reeducandos \\
\hline RO & $042 / 2006$ & Plantando Mudas para Mudar Vidas & Secretaria de Estado de Administração Penitenciária & 60 pessoas \\
\hline MT & $043 / 2006$ & Capacitação de Agentes de Escolta & $\begin{array}{c}\text { Secretaria de Estado de Justiça e Segurança Pública do Estado de } \\
\text { Mato Grosso }\end{array}$ & 65 agentes \\
\hline MT & $044 / 2006$ & $\begin{array}{l}\text { Projeto Treinamento Básico para } \\
\text { Docentes }\end{array}$ & $\begin{array}{c}\text { Secretaria de Estado de Justiça e Segurança Pública do Estado de } \\
\text { Mato Grosso }\end{array}$ & 30 docentes \\
\hline $\mathrm{AM}$ & $045 / 2006$ & Implantação da Escola Penitenciária & Secretaria de estado de justiça e Direitos Humanos & Implnatação da Escola \\
\hline MA & $046 / 2006$ & Projeto Educação Profissional & Serviço Nacional de Aprendizagem Comercial & 241 pessoas \\
\hline RO & $047 / 2006$ & Projeto Arca das Letras & Secretaria de Estado de Administração Penitenciária & 20 pessoas \\
\hline MT & 048/2006 & $\begin{array}{l}\text { Fábrica de Saneantes para o Sistema } \\
\text { Prisional do Estado }\end{array}$ & Secretaria de Estado de Justiça e Segurança Pública & 48 detentos \\
\hline $\mathrm{AP}$ & 049/2006 & $\begin{array}{l}\text { Projeto Brinquedoteca - Desafios e } \\
\text { Descobertas }\end{array}$ & Secretaria de Estado da Justiça e da Segurança & $\begin{array}{l}40 \text { mulheres, } 28 \text { companheiros e } 62 \\
\text { crianças }\end{array}$ \\
\hline MA & $051 / 2006$ & Projeto Arca das Letras & Secretaria de Estado de Justiça e Cidadania & 20 pessoas \\
\hline RS & $054 / 2006$ & $\begin{array}{l}\text { Reaparelhamento da Escola } \\
\text { Penitenciária }\end{array}$ & Secretaria de Estado de Justiça e Segurança & Reaparelhamento da Escola \\
\hline $\mathrm{RN}$ & $055 / 2006$ & Projeto Mente Livre: Yoga nas Prisões & Secretaria da Justiça e da Cidadania & 200 pessoas privadas de liberdade \\
\hline $\mathrm{RN}$ & $056 / 2006$ & Implantação da Escola Penitenciária & Secretaria da Justiça e da Cidadania & Implantação da Escola \\
\hline $\mathrm{PE}$ & $058 / 2006$ & Implantação da Escola Penitenciária & Secretaria de Defesa Social & Implantação da Escola \\
\hline PI & 059/2006 & $\begin{array}{c}\text { Projeto Edhucar: Educação em Direitos } \\
\text { Humanos e Serviços Penais na Escola } \\
\text { penitenciária }\end{array}$ & Secretaria da Justiça e de Direitos Humanos & 200 agentes \\
\hline RO & 060/2006 & Projeto Reconstruindo a Dignidade & Secretaria de Estado de Administração Penitenciária & $\begin{array}{l}210 \text { reeducandos ( } 170 \text { homens e } 40 \\
\text { mulheres) }\end{array}$ \\
\hline GO & $061 / 2006$ & Projeto Justiça com Justiça & Secretaria de Estado de Justiça & 2.186 pessoas \\
\hline $\mathrm{RJ}$ & $062 / 2006$ & Projeto KK - trabalho e Cidadania & universidade Federal Fluminense & 100 pessoas privadas de liberdade \\
\hline $\mathrm{AL}$ & $063 / 2006$ & Projeto Nascer da Terra & Secretaria Executiva de Ressocialização & 40 pessoas \\
\hline $\mathrm{CE}$ & $067 / 2006$ & $\begin{array}{l}\text { Projeto de Implantação da Escola } \\
\text { Penitenciária }\end{array}$ & Secretaria da Justiça e Cidadania & Implantação da Escola \\
\hline $\mathrm{DF}$ & 069/2006 & $\begin{array}{c}\text { Formação de Agentes Penitenciários em } \\
\text { Educação a Distância }\end{array}$ & Serviço Nacional de Aprendizagem Industrial & 60 Agentes \\
\hline SP & $071 / 2006$ & $\begin{array}{c}\text { Plano Nacional de Saúde do Sistema } \\
\text { Penitenciário }\end{array}$ & Secretaria de Administração Penitenciária & Aparelhamento de unidades. \\
\hline SP & $073 / 2006$ & $\begin{array}{c}\text { Concurso de Produção Literária para } \\
\text { Internos e Apenados do Sistema } \\
\text { Penitenciário Nacional }\end{array}$ & Associação de Alfabetização Solidária & $\begin{array}{c}499 \text { unidades prisionais. Sendo } 173 \\
\text { presídios }\end{array}$ \\
\hline
\end{tabular}

